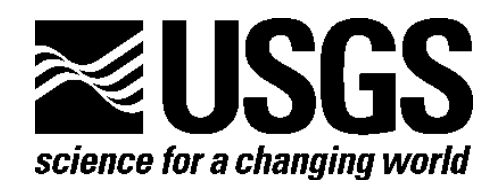

\title{
Seismic Calibration Shots Conducted in 2009 in the Imperial Valley, Southern California, for the Salton Seismic Imaging Project (SSIP)
}

By Janice Murphy, Mark Goldman, Gary Fuis, Michael Rymer, Robert Sickler, Summer Miller, Lesley Butcher, Jason Ricketts, Coyn Criley, Joann Stock, John Hole, and Greg Chavez

Open-File Report 2010-1295

U.S. Department of the Interior

U.S. Geological Survey 


\section{U.S. Department of the Interior \\ KEN SALAZAR, Secretary}

\section{U.S. Geological Survey \\ Marcia K. McNutt, Director}

U.S. Geological Survey, Reston, Virginia: 2011

For product and ordering information:

World Wide Web: http://www.usgs.gov/pubprod

Telephone: 1-888-ASK-USGS

For more information on the USGS-the Federal source for science about the Earth, its natural and living resources, natural hazards, and the environment:

World Wide Web: http://www.usgs.gov

Telephone: 1-888-ASK-USGS

Suggested citation:

Murphy, J., Goldman, M., Fuis, G., Rymer, M., Sickler, R., Miller, S., Butcher, L., Ricketts, J., Criley, C., Stock, J., Hole, J., and Chavez, G., 2011, Seismic calibration shots conducted in 2009 in the Imperial Valley, southern California, for the Salton Seismic Imaging Project (SSIP): U.S. Geological Survey Open-File Report 2010-1295, 79 p. and spreadsheet [http://pubs.usgs.gov/of/2010/1295/].

Any use of trade, product, or firm names is for descriptive purposes only and does not imply endorsement by the U.S. Government.

Although this report is in the public domain, permission must be secured from the individual copyright owners to reproduce any copyrighted material contained within this report. 


\section{Contents}

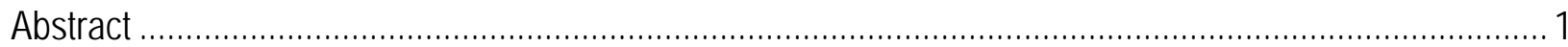

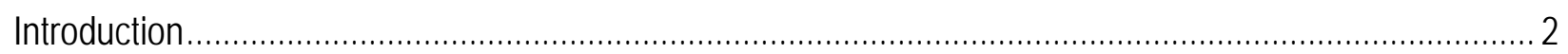

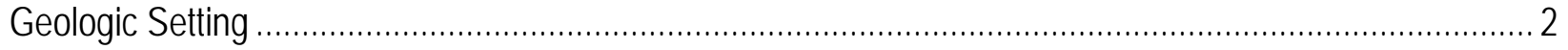

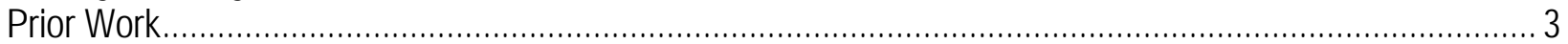

Goals of Calibration Shots ............................................................................................... 3

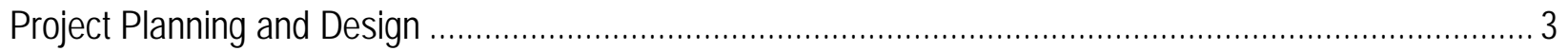

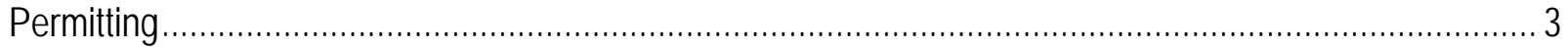

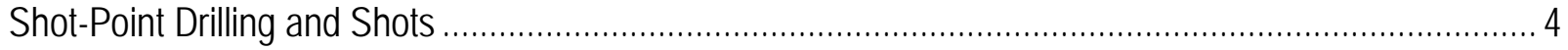

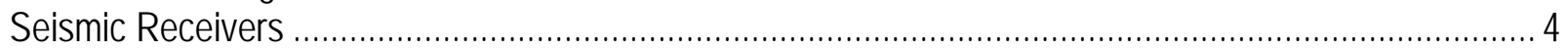

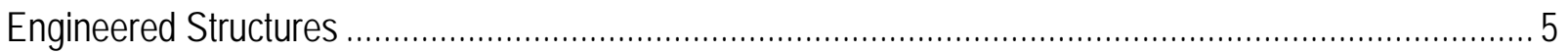

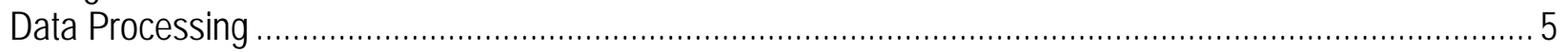

Shot Times

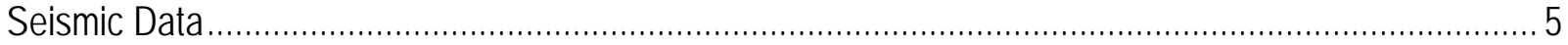

Results.

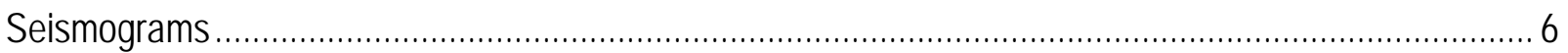

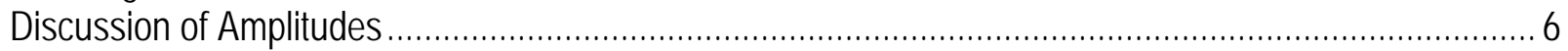

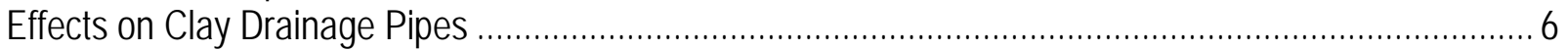

Clean Up

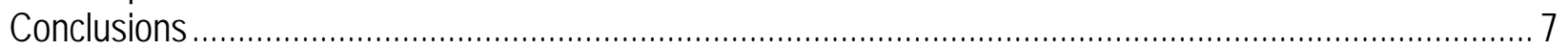

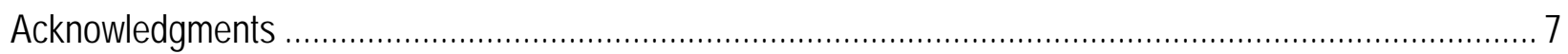

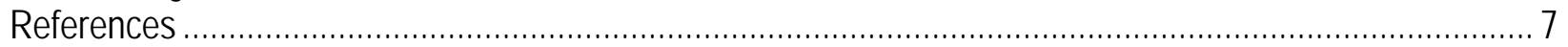

\section{Figures}

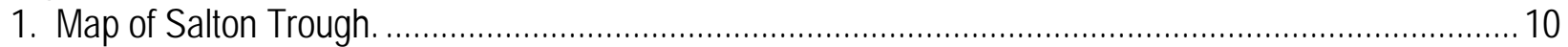

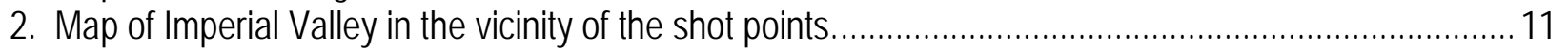

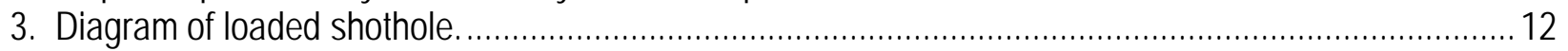

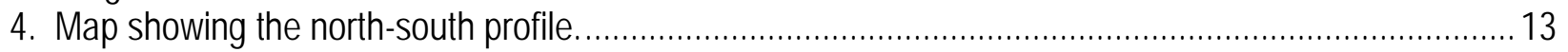

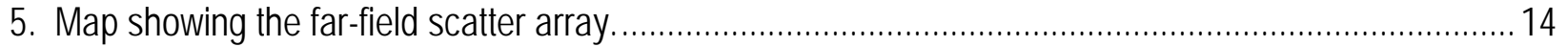

6. Map of the shot point area showing the location of the trench....................................................... 15

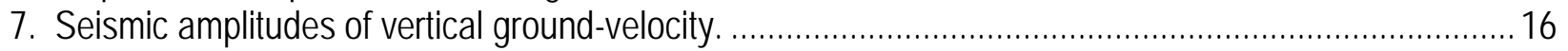

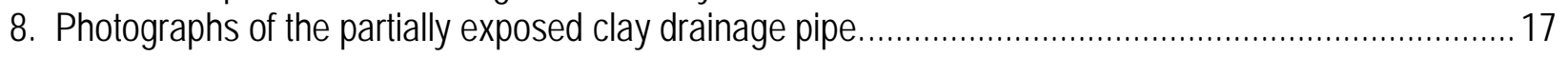

\section{Appendixes}

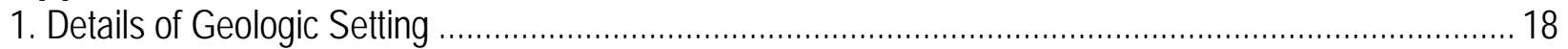

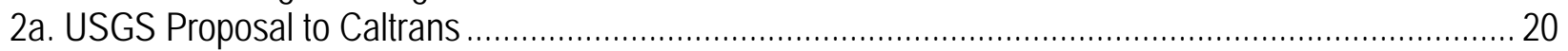

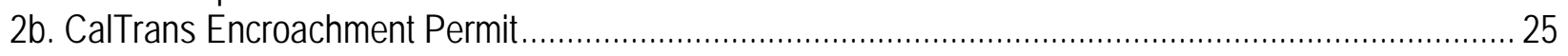

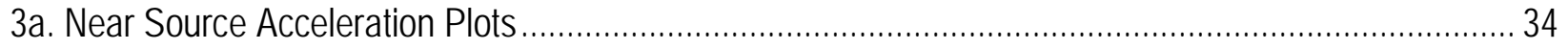

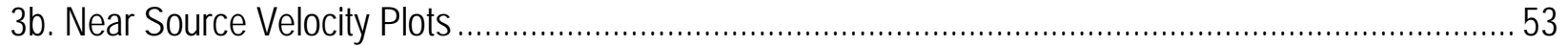

4. Near Source High Resolution Receiver Velocity Plots............................................................... 72

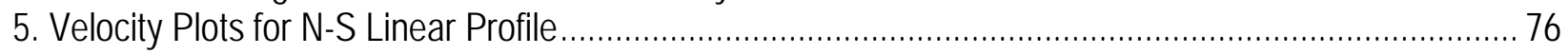




\section{Tables}

1a. Shotpoint locations and shot times ................................................................. linked spreadsheet

1b. Shotpoint depths and water contents................................................................ linked spreadsheet

1c. Charge size and additional remarks............................................................... linked spreadsheet

2. Seismic receiver locations ............................................................................. linked spreadsheet

3a. Seismic Receiver - type, number, and recording parameters ................................... linked spreadsheet

3b. Seismic Receiver geophone - type and parameters ............................................. linked spreadsheet

4a. Peak-to-peak acceleration amplitude............................................................... linked spreadsheet

4b. Peak-to-peak velocity amplitude ....................................................................... linked spreadsheet 


\title{
Seismic Calibration Shots Conducted in 2009 in the Imperial Valley, Southern California, for the Salton Seismic Imaging Project (SSIP)
}

By Janice Murphy ${ }^{1}$, Mark Goldman ${ }^{1}$, Gary Fuis' ${ }^{1}$, Michael Rymer ${ }^{1}$, Robert Sickler ${ }^{1}$, Summer Miller ${ }^{2}$, Lesley Butcher $^{1}$, Jason Ricketts ${ }^{1}$, Coyn Criley ${ }^{1}$, Joann Stock ${ }^{3}$, John Hole ${ }^{4}$, and Greg Chavez ${ }^{5}$

\begin{abstract}
The Salton Seismic Imaging Project (SSIP) is a large-scale collaborative project with the goal of developing a detailed 3-D structural image of the Salton Trough (including both the Coachella and Imperial Valleys). The image will be used for earthquake hazard analysis, geothermal studies, and studies of plate-boundary transition from an ocean-ocean to a continentcontinent plate-boundary.

As part of SSIP, a series of calibration shots were detonated in June 2009 in the southern Imperial Valley for four specific reasons: (1) to measure peak particle velocity and acceleration at various distances from the shots, (2) to calibrate the propagation of energy through sediments of the Imperial Valley, (3) to test the effects of seismic energy on buried clay drainage pipes, which are abundant throughout the irrigated parts of the Salton Trough, and (4) to test the ODEX drilling technique, which uses a downhole casing hammer for a tight casing fit.

Currently, we are using information obtained from the calibration shots to plan the data collection phase of the SSIP project. We have validated the use of ground-motion tables developed with Los Angeles Region Seismic Experiment (LARSE) data for use in the Imperial Valley and we have demonstrated that seismic energy from shots will not damage the drainage pipes used throughout the Salton Trough for irrigation.
\end{abstract}

${ }^{1}$ U.S. Geological Survey

${ }^{2}$ California Institute of Technology; now at University of Alaska Fairbanks

${ }^{3}$ California Institute of Technology

${ }^{4}$ Virginia Polytechnic Institute and State University

${ }^{5}$ IRIS-PASSCAL 


\section{Introduction}

Rupture of the southern section of the San Andreas Fault, from the Coachella Valley to the Mojave Desert, is believed to be the greatest natural hazard facing California in the near future. With an estimated magnitude between 7.2 and 8.1, such an event would result in violent shaking, loss of life, and disruption of lifelines (freeways, aqueducts, power, petroleum, and communication lines) that would bring much of southern California to a standstill. As part of the Nation's efforts to prevent a catastrophe of this magnitude, a number of projects are underway to increase our knowledge of Earth processes in the area and to mitigate the effects of such an event.

One such project is the Salton Seismic Imaging Project (SSIP), which is a collaborative venture between the United States Geological Survey (USGS), California Institute of Technology (Caltech), and Virginia Polytechnic Institute and State University (Virginia Tech). This project will generate and record seismic waves that travel through the crust and upper mantle of the Salton Trough. With these data, we will construct seismic images of the subsurface, both reflection and tomographic images. These images will contribute to the earthquake-hazard assessment in southern California by helping to constrain fault locations, sedimentary basin thickness and geometry, and sedimentary seismic velocity distributions. Data acquisition is currently scheduled for winter and spring of 2011.

The design and goals of SSIP resemble those of the Los Angeles Region Seismic Experiment (LARSE) of the 1990's (Murphy and others, 1996; Henyey and others, 1999; Fuis and others, 2001a,b; Murphy and others, 2002; Fuis and others, 2003). LARSE focused on examining the San Andreas Fault system and associated thrust-fault systems of the Transverse Ranges. LARSE was successful in constraining the geometry of the San Andreas Fault at depth and in relating this geometry to mid-crustal, flower-structure-like decollements in the Transverse Ranges that splay upward into the network of hazardous thrust faults that caused the 1971 M 6.7 San Fernando and 1987 M 5.9 Whittier Narrows earthquakes. The project also succeeded in determining the depths and seismic-velocity distributions of several sedimentary basins, including the Los Angeles Basin, San Fernando Valley, and Antelope Valley. These results advanced our ability to understand and assess earthquake hazards in the Los Angeles region.

In order to facilitate permitting and planning for the data collection phase of SSIP, in June of 2009 we set off calibration shots and recorded the seismic data with a variety of instruments at varying distances (fig. 1). We also exposed sections of buried clay drainage pipe near the shot points to determine the effect of seismic energy on the pipes. Clay drainage pipes are used by the irrigation districts in both the Coachella and Imperial Valleys to prevent ponding and remove salts and irrigation water. This report chronicles the calibration project. We present new near-source velocity data that are used to test the regression curves that were determined for the LARSE project. These curves are used to create setback tables (Fuis and others, 2001a) to determine explosive charge size and for placement of shot points. We also found that our shots did not damage the irrigation pipes and that the ODEX drilling system did well in the clay rich soils of the Imperial Valley.

\section{Geologic Setting}

The Salton Trough is a tectonically complex basin that is affected by three geologic systems: the Colorado River depositional region, the San Andreas transform fault system, and the Gulf of California extensional province (fig. 1). Compressional tectonics associated with a 
major bend in the San Andreas Fault in the north end of the Salton Trough competes with extensional tectonics farther south. For more detail on the geologic setting, see appendix 1.

\section{Prior Work}

Early seismic work in the Salton Trough by Biehler and others (1964) consisted of short (10 to $30 \mathrm{~km}$ ) seismic-refraction lines. A more extensive seismic-refraction study in 1979 (Fuis and others, 1982, 1984; Fuis and Kohler, 1984) consisted of longer (30 to $90 \mathrm{~km}$ ) profiles, 1-kmspaced seismic receivers, and seven shot points that were fired repeatedly. In 1991, additional shot points and profiles augmented this survey, as described in Parsons and McCarthy (1996). These two later surveys chiefly addressed structures - faults and sedimentary-basin depths and shapes - of the Imperial Valley.

The SSIP will extend the prior studies geographically into the Coachella Valley and to upper-mantle depths throughout the Salton Trough. The project will also provide higher resolution tomographic and reflection images because it includes a significant increase in the number of shot points (170) and a significant decrease in seismic receiver spacing (100 to 200 $\mathrm{m})$.

\section{Goals of Calibration Shots}

In June 2009, before the data collection phase of SSIP, several test shots were fired and recorded with four different types of instrumentation. The information gained from these test shots is needed to design several important aspects of the final project. First, these test shots measured peak particle velocity and acceleration at various distances from the shot points. During the LARSE project, we developed tables of particle motion versus shot size and distance that enable us to determine ground shaking from our shots at nearby buildings and engineered structures (Fuis and others, 2001a). With the calibration data, we will update the tables for expected ground motion in the Imperial Valley. Second, the shot data are used to calibrate the propagation of energy through sediments of the Imperial Valley. With these data, we can make adjustments to the SSIP plan that will allow us to maximize our imaging results. Third, the shots were used to test the effect of seismic energy on buried clay drainage pipes. Understanding this effect is essential to the permitting process because drainage pipes are present throughout the Salton Trough. Finally, we tested the ODEX drilling technique, which uses a downhole casing hammer for installation of casing during drilling and for a tight casing fit. It is necessary to find a suitable drilling technique because the lake clays of the Salton Trough are mobile and can quickly close a drilled hole.

\section{Project Planning and Design}

\section{Permitting}

The three shots points were located in a fallow field on land owned by the California Department of Public Transportation (CalTrans). All of the 6-channel receivers, the Geometrics cabled array, two Texans, and some of the 3-channel receivers were deployed in this field. All other instruments were deployed along roads in the Caltrans right-of-way. See appendix 2 for our proposal to Caltrans and the Caltrans Encroachment Permit. 


\section{Shot-Point Drilling and Shots}

Three buried explosive charges (shots) were used as sources of seismic energy. The three shot points were located near the southeast corner of Highway 7 and Heber Road (table 1a, fig. 2), $18 \mathrm{~km}$ southeast of El Centro, Calif. fig. 1). They were arranged linearly in an approximately north-south array, with an average spacing of $16 \mathrm{~m}$ (fig. 2). Each hole was drilled to a depth between 20 and $27 \mathrm{~m}$ and filled with an ammonium nitrate-based blasting agent, embedded boosters, and a detonating cord (fig. 3). The northernmost shot point (SP1) was drilled to a depth of $20.7 \mathrm{~m}$ and filled with $27 \mathrm{~kg}(60 \mathrm{lbs})$ of explosive (tables $1 \mathrm{~b}$ and $1 \mathrm{c})$. The second shot point (SP2) was drilled to a depth of $23.5 \mathrm{~m}$ and filled with $68 \mathrm{~kg}(150 \mathrm{lbs})$ of explosive. The third and southernmost shot point (SP3) was drilled to a depth of $27 \mathrm{~m}$ and filled with 123 $\mathrm{kg}$ (270 lbs) of explosive.

We used the ODEX drilling system, which employs an air-hammer drill and a downhole casing hammer. It was necessary to lubricate the air-hammer drill with water to control the adherence of clay to the drill stem. Drilling of the third and deepest shot hole caused an initial rise of a sand and water slurry to a depth of $\sim 15 \mathrm{~m}$ in the cased hole. This slurry was washed out with water, and a water column was left in the hole to prevent further slurry rise. Each hole was plugged with bentonite pellets before and after loading the explosives (plugs were placed at the bottom of the hole and at the top of the explosive column; see fig. 3). After loading the hole, the top of each explosive column was approximately of $18 \mathrm{~m}(60 \mathrm{ft})$ below the surface. Washed gravel was shoveled on top of the upper bentonite seal to a depth of $1.5 \mathrm{~m}$ below the ground surface. Minutes before the shot time, a detonating cap was attached to the detonating cord in each hole. To reduce possible airwaves, the cord and cap were lowered into the borehole and covered with gravel. Detonation of all three holes ejected a mixture of water and gravel to heights of $\sim 6$ to $9 \mathrm{~m}(20$ to $30 \mathrm{ft})$. After detonation the holes at SP1 and SP3 retained some gravel; SP2 ejected all the gravel and was open to the bottom after detonation.

\section{Seismic Receivers}

We deployed a diverse group of seismic receivers to record the shots (table 2; fig. 2). These instruments included six 6-channel REF TEK RT130's, seven 3-channel REF TEK RT130's, thirty-five 1-channel REF TEK RT125's ("Texans"), and a 60-channel Geometrics StrataView cabled array. The 6-channel instruments recorded velocity from an external 3component 2-Hz Mark Products L22 velocity sensor (tables 3a and 3b) and recorded acceleration from an internal 3-component 1500-Hz Colibrys SF 1500 accelerometer (FBA; forcefeedback)(J. Evans, Oral commun., 2010). The accelerometer has a sensitivity of $1.2 \mathrm{~V} / \mathrm{g}$ (differential), and the response is essentially flat with 1 pole and no zeros (F. Klein, Oral commun., 2010). The 3-channel instruments recorded velocity from an external 3-component 4.5-Hz Mark Products L28 velocity sensor (tables $3 \mathrm{a}$ and $3 \mathrm{~b}$ ). The Texans recorded velocity from external single-component 4.5-Hz OYO Geospace GS11 velocity sensors (tables $3 \mathrm{a}$ and $3 b)$. The StrataView recorded velocity from 60 cabled vertical-component 40-Hz L40A velocity sensors.

The 6-channel instruments were deployed at distances of $3 \mathrm{~m}$ to $130 \mathrm{~m}$ southwestward from the shot points and recorded strong motion on-scale with the accelerometers. To extend the region of 3-component recording, the 3-channel instruments were deployed at distances of 0.27 $\mathrm{km}$ to $3.4 \mathrm{~km}$ farther southwestward from the shots (fig. 2). Station 106 is a collocation site for a 6-channel receiver and a 3-channel receiver. To obtain data in the transition range from the near field to the far field, 24 Texans were deployed in a north-south line extending to $40 \mathrm{~km}$ north of 
the blast site (fig. 4). To sample far-field wave propagation, eight Texans were deployed at scattered locations east, north, and west of the shot points, at distances ranging from $35 \mathrm{~km}$ to 90 $\mathrm{km}$ (fig. 5). Two of the remaining three Texans (201 and 252) were collocated with the end-point sensors (1001 and 1060) of the cabled array and within close proximity to the blast site. The cabled array was deployed in a 300-m-long line extending from the center of the blast area northwestward (fig. 2).

The REF TEK seismic receivers were placed in pits $\sim 60 \mathrm{~cm}$ deep in firm sandy ground. The accelerometers are attached to the base of the 6-channel receivers. Therefore, to attain good coupling, the 6-channel receivers were bolted to a paver stone that was set in mortar and carefully leveled. For the sites nearest the shots (101, 102, and 103; see fig. 2), rebar was driven $\sim 1 \mathrm{~m}$ into the sand, and the paver stones were wired to the rebar to prevent potential uncoupling during shooting of the nearby shots. Sensors at all multicomponent sites were oriented with a Brunton compass to magnetic north.

For the north-south array, the single-channel Texan receivers were deployed in shallow holes along a northward trending line at intervals of 0.5 to $1 \mathrm{~km}$ within the first 2 kilometers of the shot point area. At distances greater than 2 kilometers, Texans were spaced $2 \mathrm{~km}$ apart. The single-component geophones of the cabled array were deployed at 5-m intervals along a northwest trending line (fig. 2).

\section{Engineered Structures}

In addition to recording seismic energy from the blasts, another major goal of the calibration shots was to directly observe the effect of seismic waves on buried clay drainage pipes. These pipes are used for irrigation purposes throughout the Imperial Valley and are abundant in our study area. The drainage pipes are buried at depths of 1 to $3 \mathrm{~m}$ and are used to carry away water and salts from irrigated areas. To obtain permits for detonating shots in the Salton Trough, it was first necessary to demonstrate to landowners that our shots would not damage these pipes. Toward that end, we exposed a drain near the shot points with a backhoe (fig. 6). The exposed pipe was located at distances of $7 \mathrm{~m}, 13 \mathrm{~m}$, and $15 \mathrm{~m}$ from SP1, SP2, and $\mathrm{SP} 3$, respectively (distances are perpendicular from the trench to each shot point).

\section{Data Processing}

\section{Shot Times}

Normally, shot times are determined from the USGS blaster's box. During our test shots, the timing equipment (USGS master clock) failed and the shots were fired manually. The 6component receiver nearest to the shot point was used to determine the time of each shot. Shot times were calculated by subtracting the travel time between the receiver station and the shot point from the arrival time at the receiver. A near-surface velocity of $600 \mathrm{~m} / \mathrm{s}$ was used to calculate the travel time. This velocity is based on results of a high-resolution seismic project in the Imperial Valley $23 \mathrm{~km}$ northeast of our study area (Gary Fuis, Oral commun. 2010; Michael Rymer, Oral commun., 2010; Rymer and others, 2008). Shot information is listed in table 1 a.

\section{Seismic Data}

After retrieving the seismic receivers and downloading the data, the 6-component, 3component, and Texan data were post-processed with PASSCAL programs that associated GMT time to the traces and converted the data to standard SEG-Y format (Barry and others, 1975). 
Normally, a USGS master clock is used to provide timing for the Geometrics StrataView. However, because the master clock failed in the field, the StrataView was operated manually. Therefore, timing for traces of the cabled array was relative to the end-point traces (1001 and 1060) and the Geometrics data were written to SEG-Y format without absolute time (GMT). The SEG-Y data were read into the seismic processing package, ProMAX*. For each shot, the collocated Texan receiver traces (stations 201 and 252) were cross-correlated with the two cabled-array end-point traces (station 1001 to 252 and station 1060 to 201) to get absolute time for the cabled array.

All seismograms were processed in ProMAX* to remove DC bias and convert counts to volts $/ \mathrm{m} / \mathrm{sec}$ for the velocity traces and volts/g for the acceleration traces. Maximum peak-to-peak amplitudes (table 4) were determined from the vertical-component seismogram.

\section{Results}

\section{Seismograms}

The 6-component REF TEKs recorded seismograms from the near-source area. Acceleration and velocity plots are shown in appendix 3 (acceleration in appendix 3a, velocity in appendix 3b). Receiver gathers from the StrataView cabled array are shown in appendix 4 . The transition from the near field to the far field is shown in appendix 5. These plots contain traces from the Texans and the vertical-components of the 3-component REF TEKs.

\section{Discussion of Amplitudes}

An empirical model of maximum vertical ground motion from explosive sources was developed in the late 1980s (Kohler and Fuis, 1989) and the early 1990s (Kohler and Fuis, 1992). These studies found that ground velocities are proportional to the amount of explosive and they show a strong dependence on site conditions. The models were used to create tables of shot size versus distance for a number of site conditions (setback tables). The setback tables are used to determine how much explosive can be put in a borehole and how far a shot point must be from buildings and other manmade structures. During the LARSE project, before the second LARSE transect, the model was updated with data from the first transect and a new set of setback tables were developed (Fuis, 2001a). These setback tables were used in the planning phase of LARSE II. In figure 7, we plot amplitude data from the calibration shots (shots $1 \& 2$ ) and overlay the regression curves from the LARSE model. Amplitudes from shots 1 and 2 were picked within 3 seconds of the shot time. Because of drilling complications, shot 3 failed to produce the expected energy from a 250-lb shot, and so the data are not plotted. We find the no distance-weighted regression curve fits the Imperial Valley data best at distances less than 200 meters. These data validate the use of our setback tables (Fuis, 2001a) in the Imperial and Coachella valleys.

\section{Effects on Clay Drainage Pipes}

After each shot, the exposed section of pipe closest to the shot point was examined visually (figs. 6 and 8). We found no damage to any parts of the pipe. Inspection of the exposed pipe by an engineer from the Imperial Irrigation District (IID) the following morning also found that our shots did not damage the pipe. 


\section{Clean Up}

After our tests, the drillhole casing for each shot point was cut off $\sim 1 \mathrm{~m}$ below the ground surface and a cap was welded to the top of the casing. Rebar and pavers were removed from the 6-component receiver holes. All holes and trenches were filled in and returned to their approximate original state. One year after the project, the area looked undisturbed (Michael Rymer, Oral commun., 2010).

During excavation of the drainage pipes, a section of pipe in the northern trench (near SP1) was damaged by the backhoe. The broken section of pipe was replaced with PVC pipe during the clean-up phase.

\section{Conclusions}

Our tests demonstrated that the planned SSIP work will not damage the irrigation pipes used throughout the Imperial and Coachella Valleys. We find that the ODEX drilling system is a useful drilling technique for boreholes drilled in clay-rich soils. Finally, we find that setback tables determined from other projects are valid in the Imperial Valley. This information is important because the tables are used to determine the size of the explosive charge and the location of shot points relative to buildings and other structures.

\section{Acknowledgments}

We thank Caltrans (State of California) for allowing us to operate on their land and put seismic recorders in their road right-of-way. We are grateful to the staff at the IRIS-PASSCAL Instrument Center for their help with the instrumentation and software. We especially thank Caltech students Steven Skinner, Yunung Nina Lin, and Wang Yu for their help in the field. They worked tirelessly in temperatures well over 100 degrees and late into the night to the early hours of the morning.

\section{References}

Barry, K.M., Cavers, D.A., and Kneale, C.W., 1975, Recommended standards for digital tape formats: Geophysics, v. 32, p. 1073-1084.

Biehler, Shawn, Kovach, R.L., and Allen, C.R., 1964, Geophysical framework of northern end of Gulf of California structural province, in van Andel, T.H., and Shor, G.G., Jr., eds., Marine geology of the gulf of California, American Association of Petroleum Geologists Memoir 3, p.126-143.

Brothers, D.S., Driscoll, N.W., Kent, G.M., Harding, A.J., Babcock, J.M., and Baskin, R.L., 2009, Tectonic evolution of the Salton Sea inferred from seismic reflection data: Nature Geoscience, v. 2, p. 581-584.

Dair, L., and Cooke, M.L., 2009, San Andreas Fault geometry through the San Gorgonio Pass, California: Geology, v. 37, p. 119-122.

Elders, W.A., Rex, R.W., Meidav, T., Robinson, P.T., and Biehler, S., 1972, Crustal spreading in Southern California: Science, v. 178, p. 15-24.

Fuis, G.S., and Kohler, W.M., 1984, Crustal structure and tectonism of the Imperial Valley region, California, in Rigsby, C.A., ed., The Imperial Basin-tectonics, sedimentation and thermal aspects: Pacific Section SEPM, p. 1-13.

Fuis, G.S., Mooney, W.D., Healy, J.H., McMechan, G.A., and Lutter, W.J., 1982, Crustal structure of the Imperial Valley region, in The Imperial Valley, California, earthquake of October 15, 1979: U.S. Geological Survey Professional Paper 1254, p. 25-49. 
Fuis, G. S., Mooney, W. D., Healy, J. H., McMechan, G. A., and Lutter, W. J., 1984, A seismic refraction survey of the Imperial Valley region, California: Journal of Geophysical Research, v. 89, pg. 1165-1189.

Fuis, G.S., Murphy, J.M., Okaya, D.A., Clayton, R.W., Davis, P.M., Thygesen, K., Baher, S.A., Ryberg, T., Benthien, M.L., Simila, G., Perron, J.T., Yong, A., Reusser, L., Lutter, W., Kaip, G., Fort, M.D., Asudeh, I., Sell, R., Vanschaack, J.R., Criley, E.E., Kaderabek, R., Kohler, W.M., and Magnuski, N.H., 2001a, Report for borehole explosion data acquired in the 1999 Los Angeles Region Seismic Experiment (LARSEII), southern California; Part I, description of survey: U.S. Geological Survey Open-File Report 01-408, 81 p.

Fuis, G.S; Ryberg, T., Godfrey, N.J., Okaya, N.J., and Murphy, J.M., 2001b, Crustal structure and tectonics from the Los Angeles Basin to the Mojave Desert, Southern California: Geology, v. 29, p. 15-18.

Fuis, G.S., Clayton, R.W., Davis, P.M., Ryberg, T., Lutter, W.J., Okaya, D.A., Hauksson, E., Prodehl, C., Murphy, J.M., Benthien, M.L., Baher, S.A., Kohler, M.D., Thygesen, K., Simila, G., and Keller, G.R., 2003, Fault systems of the 1971 San Fernando and 1994 Northridge earthquakes, southern California; relocated aftershocks and seismic images from LARSE II: Geology, v. 31, p. 171-174.

Helenes, J., and Carreño, A.L., 1999, Neogene sedimentary evolution of Baja California in relation to regional tectonics: Journal of South American Earth Sciences, v. 12, p. 589605.

Henyey, T.L., Fuis, G.S., Benthien, M.L., Christofferson, S.A., Clayton, R.W., Davis, P.M., Hendley, J.W., II, Kohler, M.D., Lutter, W.J., McRaney, J.K., Murphy, J.M., Okaya, D.A., Ryberg, T., Simila, G.W., and Stauffer, P.H., 1999, The "LARSE” Projectworking toward a safer future: U.S. Geological Survey Fact Sheet 110-99.

Johnson, C.E., and Hadley, D.M., 1976, Tectonic implications of the Brawley earthquake swarm, Imperial Valley, California, January 1975: Bulletin of the Seismological Society of America, v. 66, p. 1133-1144.

Kohler, W.M., and Fuis, G.S., 1989, Empirical relationship among shot size, shotpoint, site condition, and recording distance for 1984-1987 U.S. Geological Survey seismicrefraction data: U.S. Geological Survey Open-File Report 89-675, 107 p.

Kohler, W.M., and Fuis,G.S., 1992, Empirical dependence of seismic ground velocity on the weight of explosive, shotpoint site condition, and recording distance for seismicrefraction data: Bulletin of the Seismological Society of America, v. 82, p. 2032-2044.

Lee, J., Miller, M., Crippen, R., Hacker, B., and Vazquez, J., 1996, Middle Miocene extension in the gulf extensional province, Baja California; evidence from southern Sierra Juarez: Geological Society of America Bulletin, v. 108, p. 505-525.

Lin, G., Shearer, P.M., and Hauksson, E., 2007, Applying a three-dimensional velocity model, waveform cross correlation, and cluster analysis to locate Southern California seismicity from 1981 to 2005: Journal of Geophysical Research, v. 112, no. B12, B12309.

Lomnitz, C., Mooser, F., Allen, C.R., Brune, K.N., and Thatcher, W., 1970, Seismicity and tectonics of the northern Gulf of California region, Mexico-—preliminary results: Geophysics International, v. 10, p. 37-48.

Magistrale, H., 2002, The relation of the southern San Jacinto Fault zone to the Imperial and Cerro Prieto faults, in Barth, A., ed., Contributions to crustal evolution of the Southwestern United States: Geological Society of America Special Paper 365, p. 271278. 
Merriam, R., and Bandy, O.L., 1965, Source of the upper Cenozoic sediments in Colorado River Delta region: Journal of Sedimentary Petrology, v. 35, p. 911-916.

Muffler, L.J.P., and Doe, B.R., 1968, Composition and mean age of detritus of the Colorado River delta in the Salton Trough, southeastern California: Journal of Sedimentary Petrology, v. 38, p. 384-399.

Murphy, J.M., Fuis, G.S., Ryberg, T., Okaya, D.A., Criley, E.E., Benthien, M.L., Alvarez, M., Asudeh, I., Kohler, W.M., Glassmoyer, G.N., Robertson, M.C., and Bhowmik, J., 1996, Report for explosion data acquired in the 1994 Los Angeles Region Seismic Experiment (LARSE94), Los Angeles, California: U.S. Geological Survey Open-File Report 96-536, $120 \mathrm{p}$.

Murphy, J.M., Fuis, G.S., Okaya, D.A., Thygesen, K., Baher, S.A., Ryberg, T., Kaip, G., Fort, M.D., Asudeh, I., and Sell, R., 2002, Report for borehole explosion data acquired in the 1999 Los Angeles Region Seismic Experiment (LARSEII), southern California. Part II, data tables and plots: U.S. Geological Survey Open-File Report 02-179, 257 p.

Nava-Sanchez, E.H., Gorsline, D. S., and Molina-Cruz, A., 2001, The Baja California peninsula borderland; structural and sedimentological characteristics: Sedimentary Geology, v. 144, p. 63-82.

Oskin, M., Stock, J., and Martin-Barajas, A., 2001, Rapid localization of Pacific-North America plate motion in the Gulf of California: Geology, v. 38, p. 459-462.

Parsons, T., and McCarthy, J., 1996, Crustal and upper mantle velocity structure of the Salton Trough, Southeast California: Tectonics, v. 15, p. 456-471.

Rymer, M.J., Goldman, M.R., Catchings, R.D., Sickler, R.R., Criley, C.J., Kass, J.B., and Knepprath, N., 2008, High-resolution, shallow seismic imaging of the Imperial Fault, Imperial County, California [abs.]: Eos (American Geophysical Union Transactions), v. 89, Fall Meeting 2008, abstract \#S13D-08.

Sharp, R.V., 1982, Tectonic setting of the Imperial Valley region, in The Imperial Valley, California, earthquake of October 15, 1979: U.S. Geological Survey Professional Paper 1254 , p. 5-14.

Stock, J.M., and Hodges, K.V., 1989, Pre-Pliocene extension around the Gulf of California and the transfer of Baja California to the Pacific Plate: Tectonics, v. 8, p. 99-115.

Van de Camp, P.C., 1973, Holocene continental sedimentation in the Salton basin, California-a reconnaissance: Geological Society of America Bulletin, v. 84, p. 827-848.

Weldon, R.J., II, Meisling, K.E., and Alexander, J., 1993, A speculative history of the San Andreas Fault in the central Transverse Ranges, California, in Powell, R.E., and others, eds., The San Andreas fault system; displacement, palinspastic reconstruction, and geologic evolution: Geological Society of America Memoir 178, p. 161-198.

Winker, C.D., 1987, Neogene stratigraphy of the Fish Creek-Vallecito Section, southern California; implications for early history of the northern Gulf of California and the Colorado Delta: Tucson, University of Arizona, Ph.D. dissertation, 622 p. 


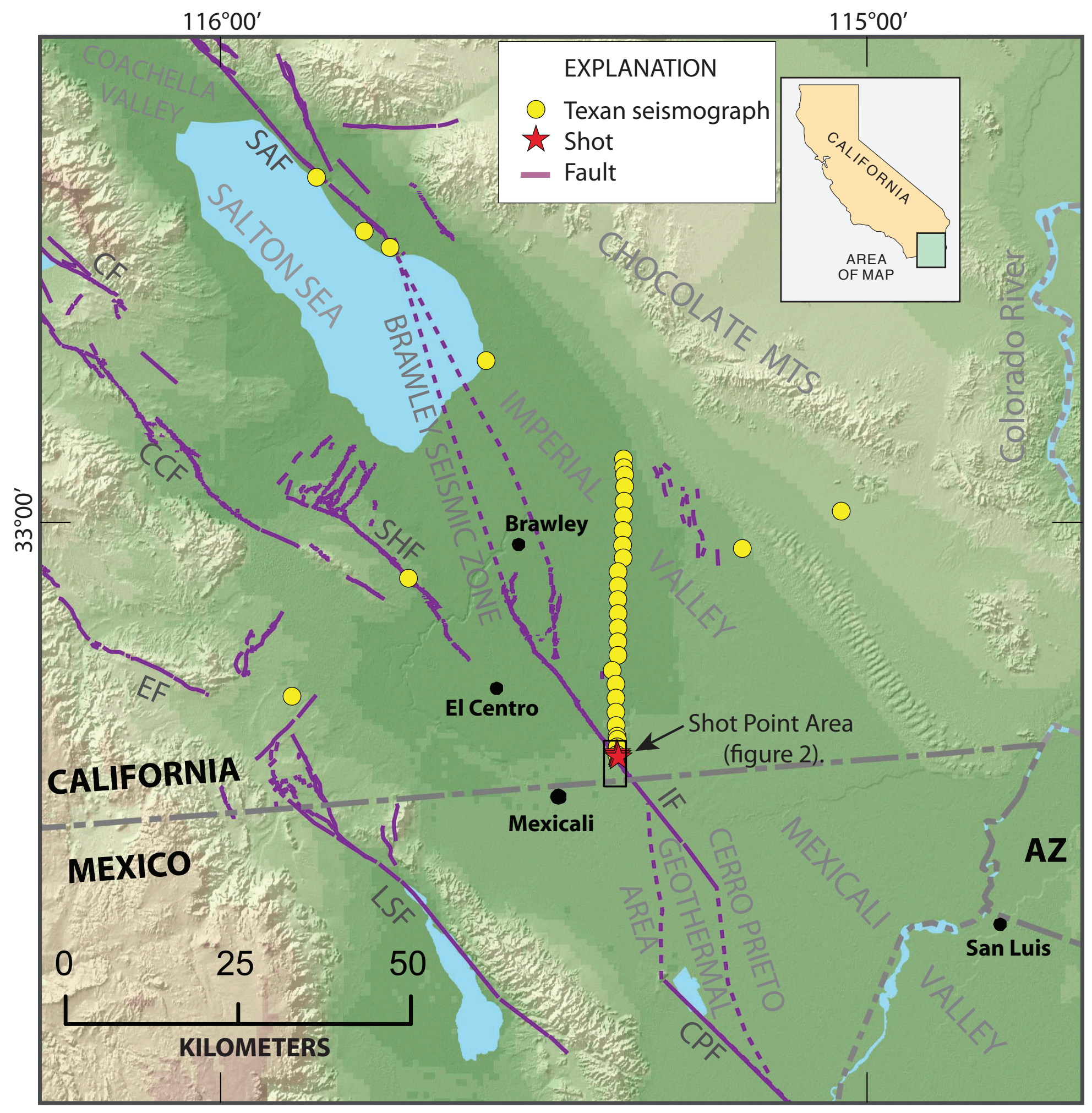

Figure 1. Map of Salton Trough. The locations of the shots, in the southern Imperial Valley, are shown with red stars. Locations of the Texan receivers are shown with yellow circles. The box outlines the shot point area map shown in figure 2. CPF, Cerro Prieto Fault; CF, Clark Fault; CCF, Coyote Creek Fault; EF, Elsinore Fault; IF, Imperial Fault; LSF, Laguna Salada Fault; SAF, San Andreas Fault; SHF, Supersition Hills Fault. 


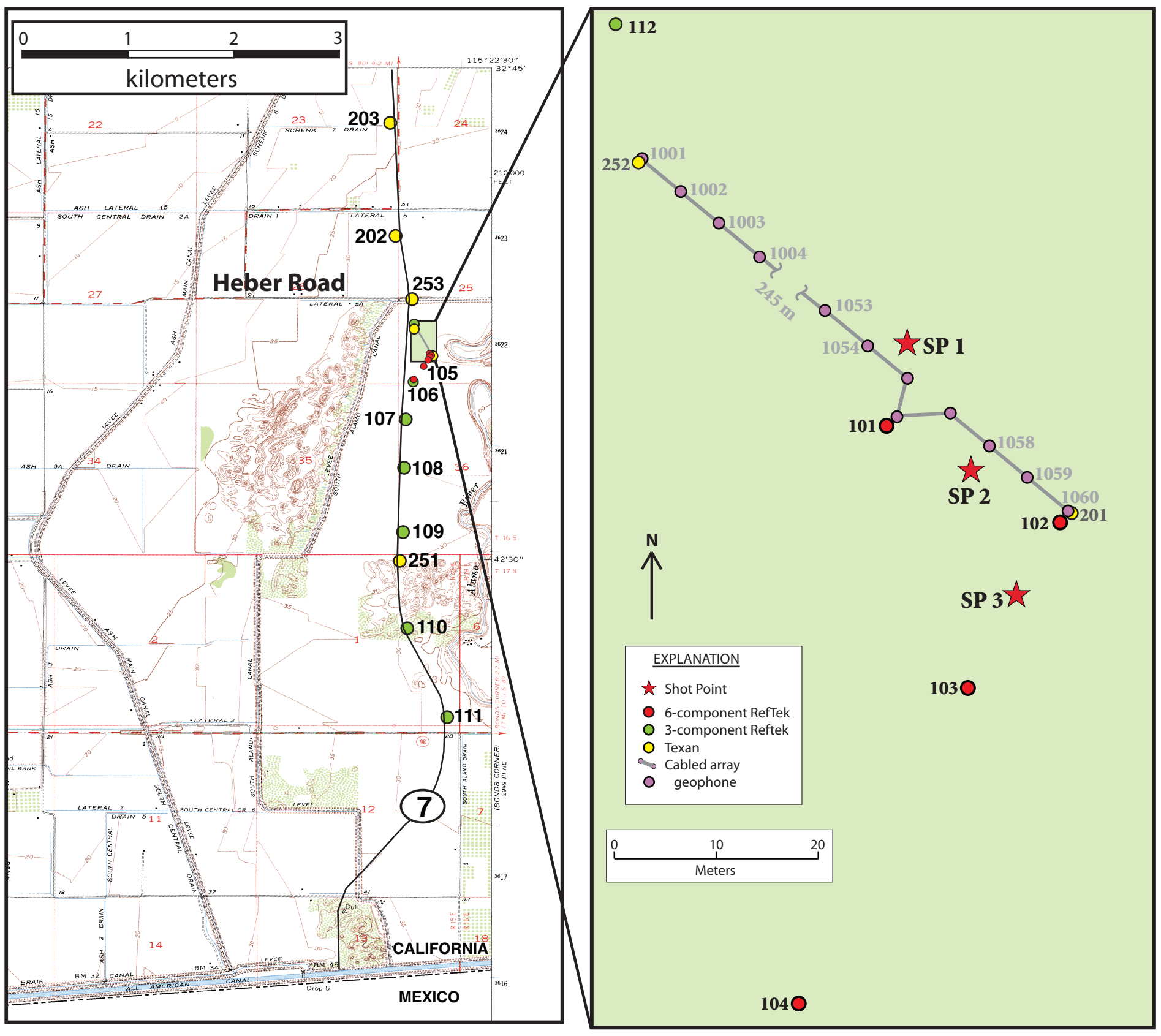

Figure 2. Map of Imperial Valley in the vicinity of the shot points. The Immediate shot point area is shown in the diagram on the right. Shot points and receivers are shown as described in explanation. 


\section{Shothole Diagram}

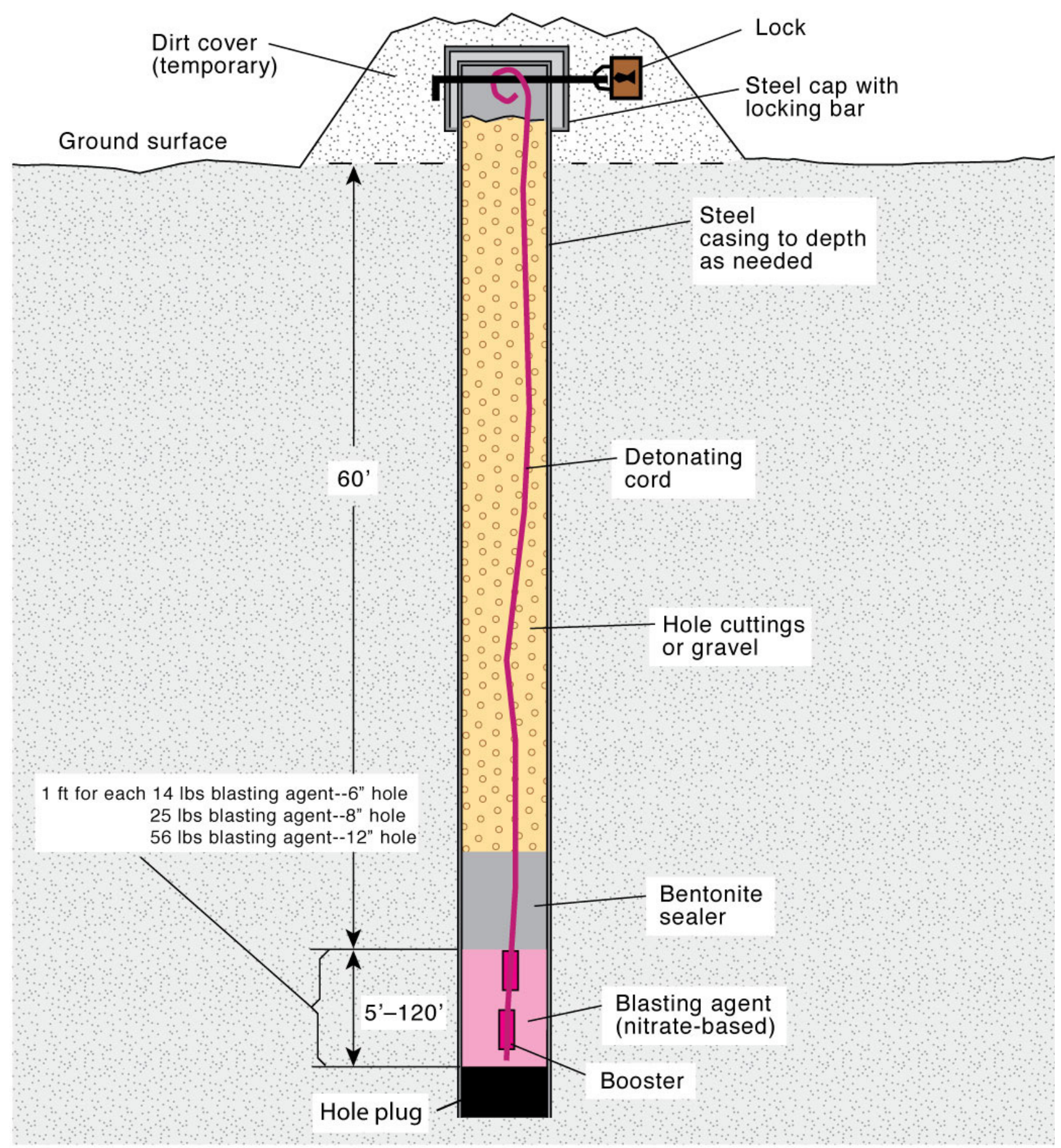

Figure 3. Diagram of loaded shothole. 


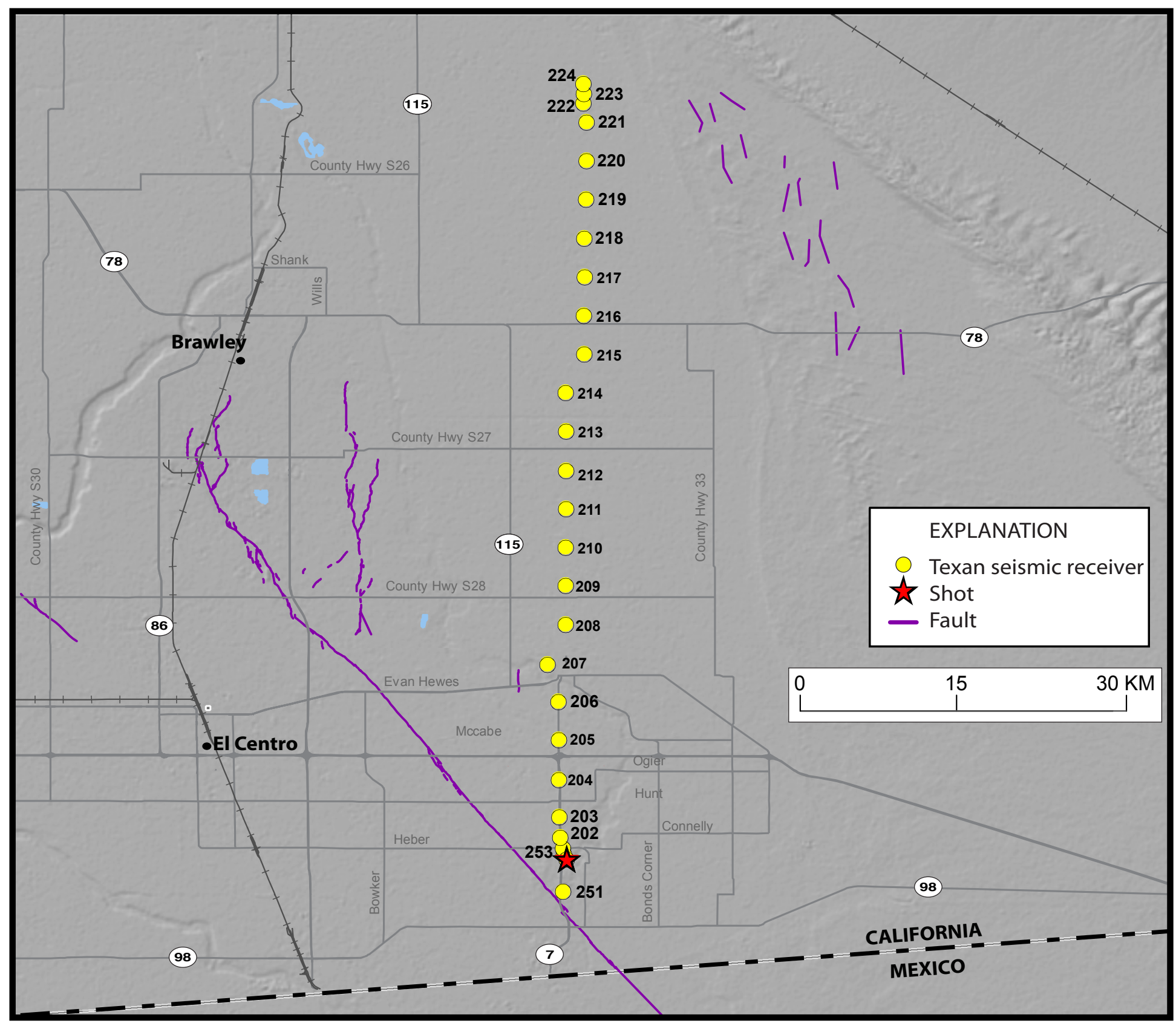

Figure 4. Map showing the north-south profile. Shot points and Texan seismic receivers are described in expanation. 


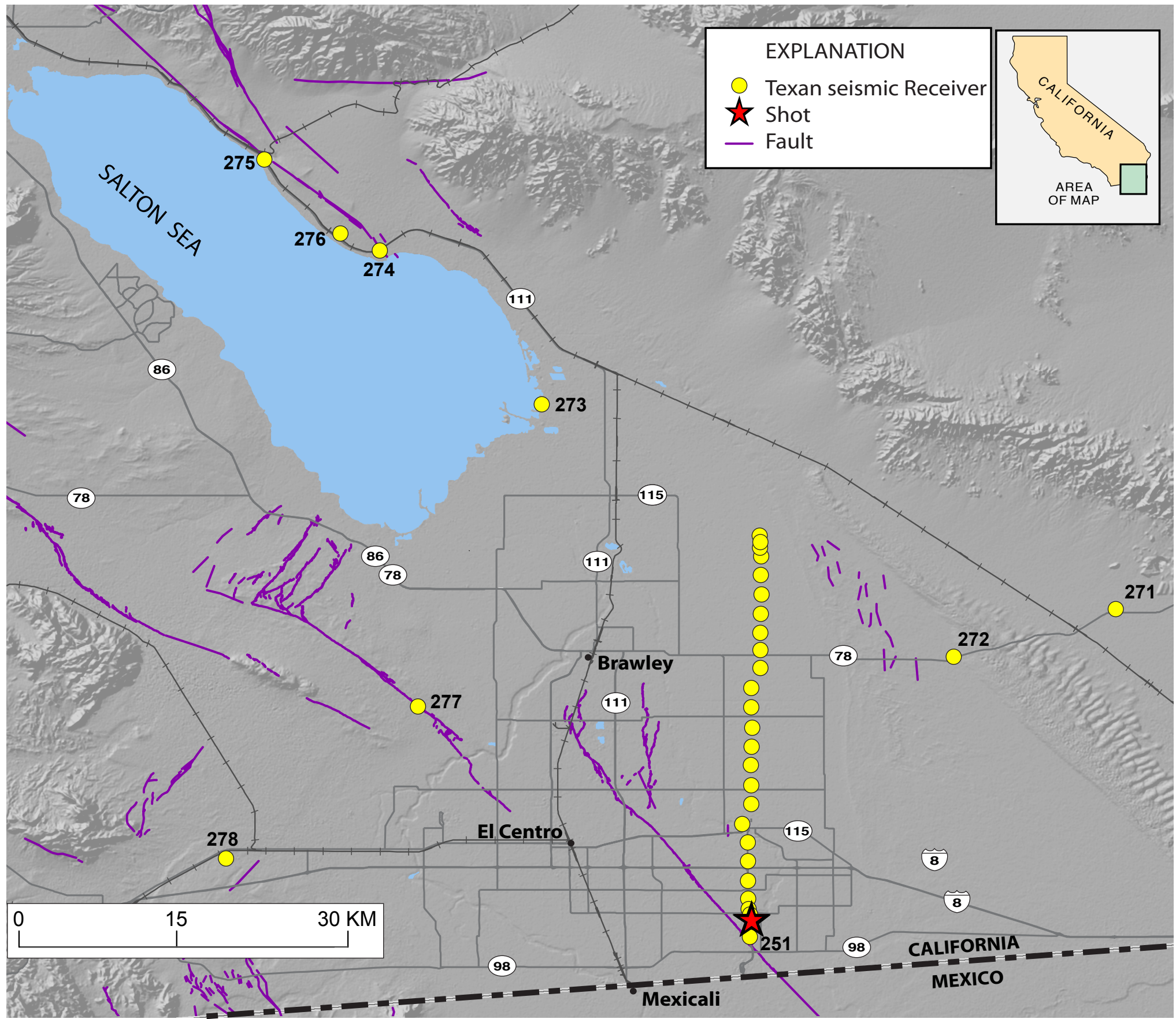

Figure 5. Map showing the far-field scatter array. 


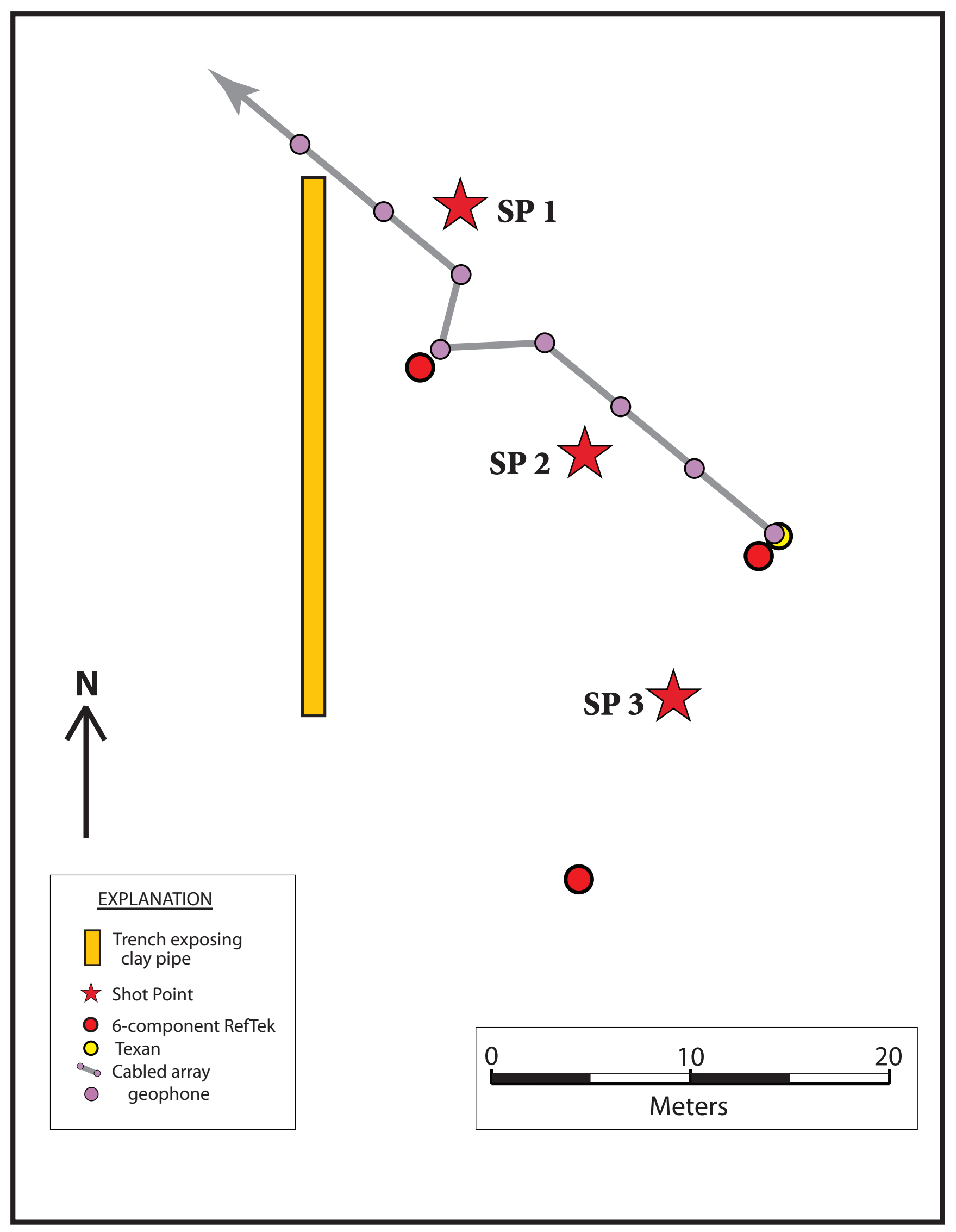

Figure 6. Map of the shot point area with the location of the trench where clay drainage pipes were exposed (orange bar). Shot points and receivers are shown as described in explanation. 
$A$

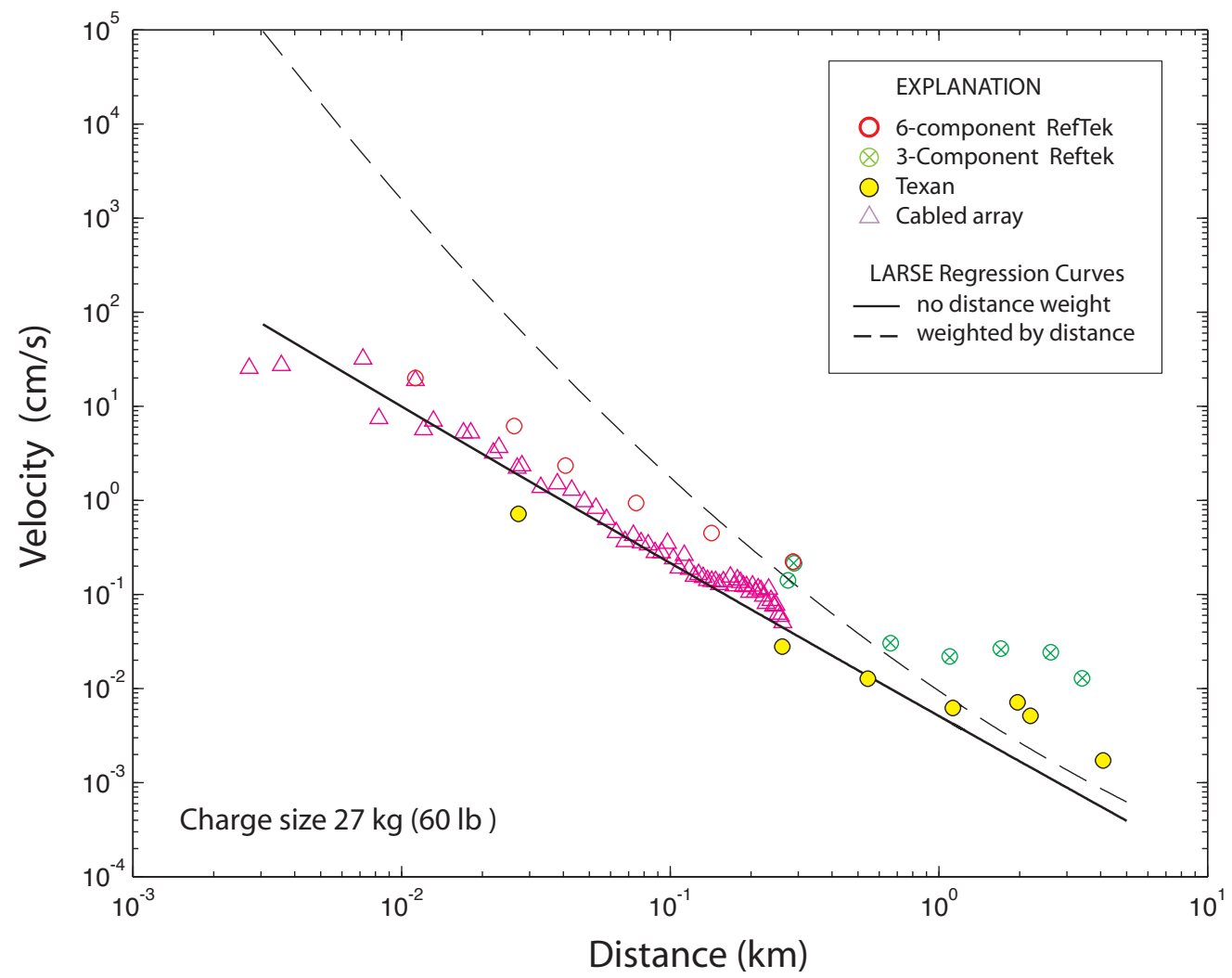

$B$

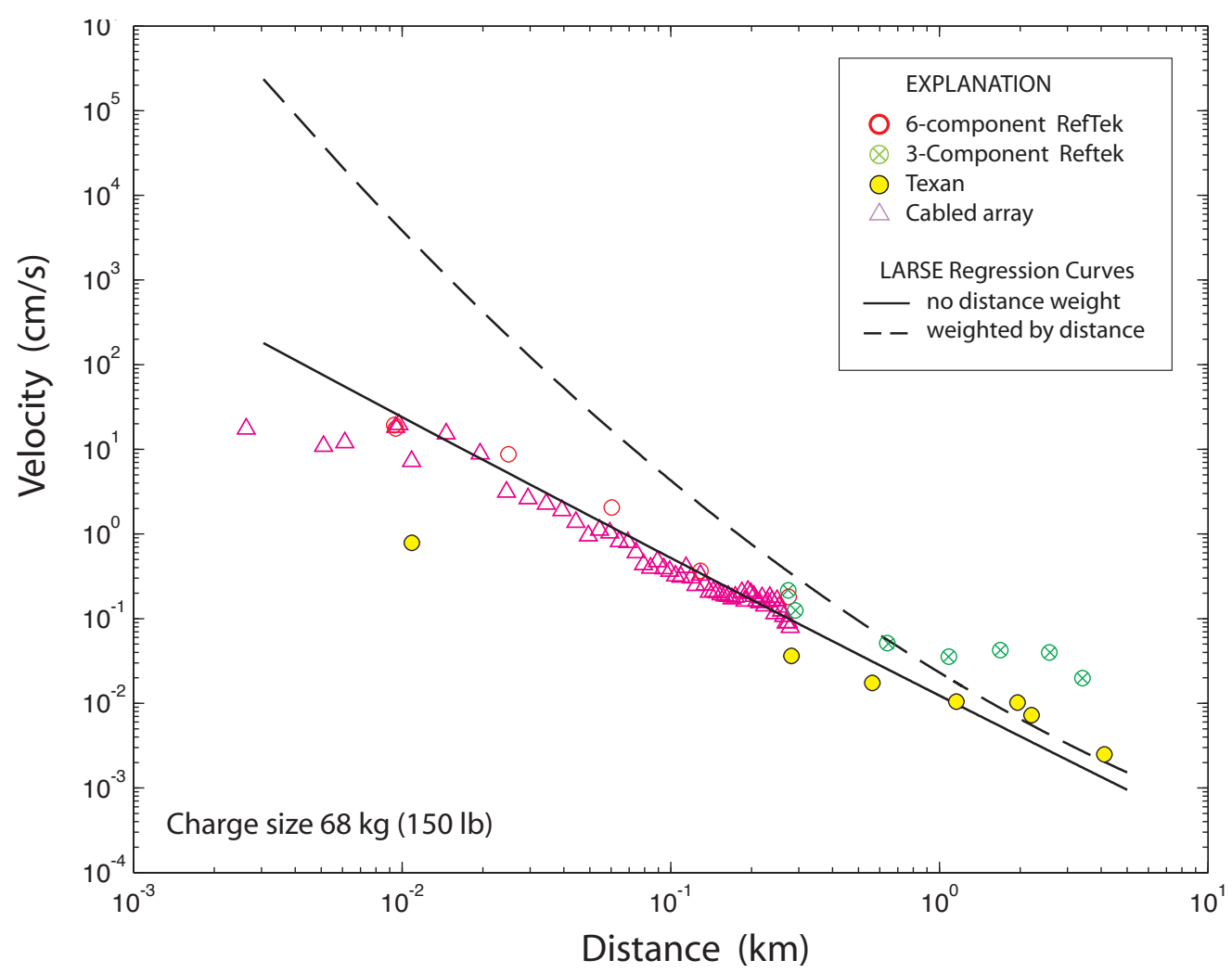

Figure 7. Seismic amplitudes of vertical ground velocity versus distance for seismic receivers within $5 \mathrm{~km}$ of shot points. Curves are determined from the LARSE data as described in the explanation. A, shot 1, charge size $27 \mathrm{~kg}(60 \mathrm{lb})$; and B, shot 2, charge size $68 \mathrm{~kg}(150 \mathrm{lb})$. 

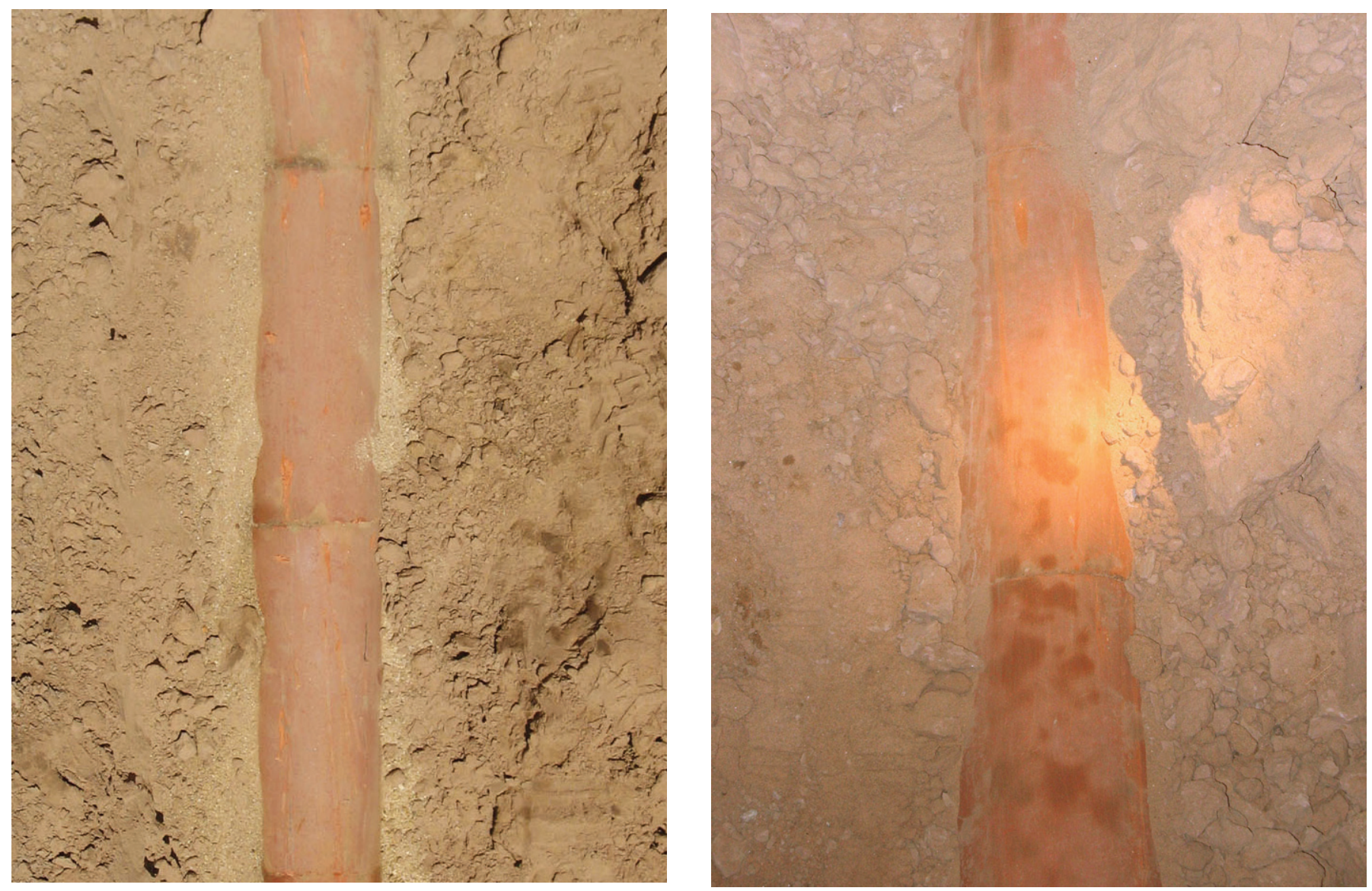

Figure 8. Photographs of the partially exposed clay drainage pipe located west of shot point 2. Left, pipe before shot; right, pipe after shot. Dark spots in right photograph are water stains from spray while the shot geysered. Pipe in photos is approximately $75 \mathrm{~cm}$ long $(3.5 \mathrm{ft})$. The diameter of the pipe is $13.5 \mathrm{~cm}$ (5.5 in). 


\section{Appendixes}

\section{Appendix 1. Details of Geologic Setting}

The Salton Trough is a tectonically complex basin that is affected by three geologic systems: the Colorado River depositional region, the San Andreas transform fault system, and the Gulf of California extensional province. Compressional tectonics associated with a major bend in the San Andreas Fault at the north end of the Salton Trough competes with extensional tectonics farther south (see for example, Dair and Cooke, 2009).

Initial dextral displacement and extension in the Gulf of California began as early as 12 Ma (Stock and Hodges, 1989; Weldon and others, 1993; Lee and others, 1996; Helenes and Carreño, 1999; Oskin and others, 2001) and subsequent trans-tensional faulting opened the Gulf of California and moved Baja California north relative to the stable North American Plate. The deep basins of the southern Gulf are underlain by oceanic lithosphere due to continued extension (Nava-Sanchez and others, 2001), whereas transitional crust, consisting of Colorado River sediments and intrusive magmatic rock, is thought to underlie the Salton Trough (Fuis and others, 1984).

The opening of the Gulf of California created a marine incursion on the North American continent in the late Neogene, and marine sedimentary rocks can be found at various outcrops throughout the Salton Trough today. The Colorado River's prograding delta has created a divide between the Salton Trough and the Gulf of California and has filled the Salton Trough with Pliocene and Pleistocene fluvial and lacustrine deposits (Merriam and Bandy, 1965; Muffler and Doe, 1968; Van de Camp, 1973; Winker, 1987).

Sedimentary units derived from different sources are present in the Imperial Valley, which forms part of the Salton Trough and lies south of the Salton Sea, east of the Peninsular Ranges, and north of the Mexican border (fig. 1). Late Cenozoic sedimentary deposits within the Imperial Valley originated in continental lacustrine and marine environments from nearby and distant sources (Sharp, 1982). Mountainous areas surrounding the valley contribute a large proportion of coarser grained detritus along the flanks of the Salton Trough. Sediment within the central part of the Trough derives mostly from the Colorado River (Merriam and Bandy, 1965; Muffler and Doe, 1968).

Scientific drilling within the Imperial Valley reveals that the thick sedimentary cover increases in metamorphic grade with depth (Elders and Sass, 1988). Seismic velocities of "basement" in the Imperial Valley are low (5.6-5.8 km/s), in contrast to basement velocities outside of the Imperial Valley $(5.9-6.1 \mathrm{~km} / \mathrm{s})$, and there is no velocity discontinuity between this "basement" and the sedimentary rocks above. Fuis and others (1984) therefore interpret the valley "basement" to be greenschist-facies-metamorphosed Colorado River sedimentary rocks. Below 10- to 16-km depth, this interpreted metamorphic sedimentary basement is underlain by a mid-crustal subbasement composed of mafic intrusions that resembles oceanic crust. This subbasement is largely confined to the central axis of the Valley (Fuis and others, 1984; Parsons and McCarthy, 1996). The 1979 seismic refraction survey of the Imperial Valley by Fuis and others $(1982,1984)$ suggests that the total thickness of both unmetamorphosed and metamorphosed sedimentary rocks ranges from $10 \mathrm{~km}$ at the northern end of the Imperial Valley to $16 \mathrm{~km}$ at the Mexican border.

Two series of northwest-striking dextral faults associated with the San Andreas and related fault zones also characterize the Imperial Valley. Along the western flank, the Elsinore 
Fault zone and the Superstition Hills and Superstition Mountain segments of the San Jacinto Fault zone originate in the Salton Trough and continue northwest to, or nearly to, the Transverse Ranges of southern California. The southernmost segment of the San Andreas Fault originates along the eastern shore of the Salton Sea in the northeast margin of the Valley. Additionally, the Imperial Fault lies along the central axis of the Valley. These faults make up a diffuse plate boundary in southern California (Lomnitz and others,1970; Elders and others,1972) that is highly active seismically (Lin and others, 2007).

Extensional tectonics occurring in the stepover regions between northwest-striking dextral faults in the Imperial Valley constitute the northernmost rifting associated with the Gulf of California extensional province. For example, the right steps between the San Andreas and Imperial Faults and between the Imperial and Cerro Prieto Faults are occupied by geothermal systems (including volcanoes) and local depressions (see, for example, Fuis and Kohler, 1984). One important puzzle is that these stepover regions are characterized chiefly by strike-slip earthquake focal mechanisms, which do not produce subsidence. For example, the Brawley Seismic Zone (BSZ), in the stepover region between the San Andreas and Imperial Faults, consists of a "ladder"-shaped pattern of strike-slip faults (Johnson and Hadley, 1976; Magistrale, 2002; Lin and others, 2007). Just west of this zone, however, normal faulting has been imaged using marine seismic-reflection techniques (Brothers and others, 2009). Most normal faulting may be aseismic.

The Salton Trough has and will continue to produce devastating earthquakes, yet the complex tectonic structure is not known well enough, particularly in the Coachella Valley, to accurately assess earthquake hazards. SSIP will improve our knowledge of tectonics, including subsurface shapes and interconnections of faults, sedimentary basin thicknesses and shapes, and seismic velocities in the sedimentary basins, and therefore help us understand the potential effects of a large earthquake. 
Appendix 2a. USGS Proposal to Caltrans 


\title{
DEPARTMENT OF THE INTERIOR \\ UNITED STATES GEOLOGICAL SURVEY \\ EARTHQUAKE HAZARDS TEAM
}

June 3, 2009

\author{
Bill Owen \\ Geophysics and Geology Branch \\ California Department of Transportation \\ Sacramento, CA \\ 916.227.0227 \\ bill.owen@dot.ca.gov
}

Dear Bill:

Thanks for your input to our original proposal to detonate 3 buried explosions within the footprint of the Brawley Bypass Project, in southern California. I hope this revised proposal addresses your concerns adequately.

The U.S. Geological Survey (USGS) Earthquake Hazards team is planning a major seismic-imaging survey of the Salton Trough (Coachella and Imperial Valleys) in the Winter/Spring of 2010. I have attached an "Info Sheet" describing the goals of this large project. This survey would utilize buried shots as sources of vibrations to produce images of the subsurface.

To initiate the permitting process for buried explosions in the Imperial Valley, which is underlain almost everywhere with buried clay and plastic drain tiles, we propose to detonate 3 test shots within short distances (50-100) ft of these tiles. The Caltrans' Brawley Bypass Project would present a unique opportunity to detonate test shots near some of the abandoned, or soon to be abandoned, drain tiles that occur within the footprint of this project. After consulting with the Bypass Project engineers, we propose to conduct our test shots in a former irrigated field southwest of the junction of Shank and Groshen roads ( $\sim 630 \mathrm{ft}$ south of Shank Rd and $\sim 970 \mathrm{ft}$ west of Groshen Rd).

The objectives of this project are the following:

1) To observe how the buried drain tiles fare during nearby shots of varying size. We plan to expose a length of these pipes and examine them before and after each shot. Proposed shotpoint sizes are $60 \mathrm{lbs}, 150 \mathrm{lbs}$, and $270 \mathrm{lbs}$. We would also invite engineers from the Imperial Irrigation District to examine these pipes.

2) To test drilling techniques in the sediments of the Imperial Valley. We plan to use a downhole casing hammer (Odex system) in as many locations as feasible during the main survey in 2010, in order to obtain tight fits of casing to drill hole and to prevent borehole collapse. Thus, we propose to test this drilling technique for the test shots, and would switch to standard rotary drilling if unsuccessful.

3) To calibrate our "setback" curves for the Imperial Valley, which we use to ensure that we do not exceed thresholds of peak particle velocities for various structures and for 
human complaints. (Our current curves are in the attached Preliminary Environmental Assessment. More detail on our drilling, loading, and shooting can be found at http://geopubs.wr.usgs.gov/open-file/of01-408/)

4) To examine logistics required for drilling, loading, instrument deployment, shooting, and cleanup in the Imperial Valley.

We propose to begin drilling during the week of June 15, and anticipate no more than 2-3 days of drilling. The footprint of the drilling would be approximately $50 \times 50 \mathrm{ft}$. The proposed holes would be 70, 80, and $90 \mathrm{ft}$ in depth and would be arranged in a triangle or line about $40 \mathrm{ft}$. apart. They would be cased to the bottom with 6-inch steel casing, plugged with bentonite, and pumped dry using an air compressor (the water would be disposed of by evaporation in fine spray).

The explosives would arrive in our own (placarded) rental truck early in the week of June 22 from Alpha Explosives, in Mojave, CA. We would load sensitized blasting agent (Titan 100 SD, a product of Alpha Explosives) into each of the drill holes. The blasting agent would be packaged in 5 x 30-inch plastic "sausages" or "chubs" (30 lbs each) and would be strung (taped) together in 3 strings (for the 3 holes) with single strands of detonating cord that are inserted into or through boosters arranged along each string. We would use a non-ferrous, non-sparking tool for cutting the detonating cord. All explosive would be loaded below $60 \mathrm{ft}$ depth beneath the ground surface. Above the explosive, we would load bentonite followed by gravel, filled to the top of the drillhole. We would lock steel caps on the tops of the loaded drill holes and would cover each with a pile of dirt, as shown in the attached Info Sheet and the Preliminary Environmental Assessment, in order to reduce visibility of the shotholes. No explosives would be stored onsite except during the loading period.

The Blasting Officer will be Coyn Criley. Blasting assistants may include Robert Sickler, Michael Rymer, Janice Murphy, Rufus Catchings, and myself. All of these personnel are USGS employees who have had regular explosives training courses and who have had years to decades of experience in handling explosives. Coyn Criley has had 10.5 years experience as a supervisory blaster.

Personal Protective Equipment would include hardhats, safety glasses, earplugs, and appropriate clothing.

For emergencies, we would retain onsite at least one appropriate fire extinguisher (in our truck) and a first-aid kit.

Licenses are not required for USGS explosives handlers, as stated in Cal/OSHA Explosives Orders Title 8, Group 18, Article 113, Part 5236, Item b: 5A, 5B, and 5C, which states that specified standards "shall not apply to operations governed by the provisions of Group 18 under contract with federal government agencies requiring compliance with DOD Contractors Safety Manual." (The Manual can be found at http://www.ddesb.pentagon.mil/2008-03-13\%20-\%20DoD\%204145.26-M.pdf). In actual practice, we follow the more detailed Cal/OSHA regulations (Title 8) and, in particular, 
the explosives training manual put out by Alpha Explosives. Our explosives handlers take explosives training courses every couple of years or so. Further requirements (in 5B and $5 \mathrm{C}$, above) for DOD surveillance and inspections are met in that we commonly perform explosives handling on military bases.

We would obtain all necessary permits from the Imperial Irrigation District, with whom we are cooperating on this project, and any other local agencies with concerns. We would notify the sheriff and local police and fire departments of our activity. We would activate Underground Services Alert prior to our drilling.

While loading the drillholes, we would deploy approximately 6 seismographs capable of recording on-scale strong ground motion within a 1-km radius of the test holes, and 5-10 other seismographs at greater distances. We may deploy an additional 45 seismographs ("Texans"- - see Info Sheet) along one or more lines extending to ranges of as much as $10-20 \mathrm{~km}$ from the shots to test signal propagation, if these instruments are available. (Their availability is uncertain at the moment.)

We plan to detonate the shots at night, when wind and cultural noise is at its lowest level near our seismographs. (Ground-noise conditions in the Imperial Valley during the daytime are too high for us to see our signals at distances of 10-20 km, our most distant proposed seismograph sites.)

Our standard shooting procedure, which follows Cal/OSHA Explosive Orders, Title 8, Group 18, Article 116, Part 5291, includes the following

1) Check the weather to ensure that no thunderstorms are approaching or within 25 miles (see Cal/OSHA Explosive Orders, Title 8, Group 18, Article 116, Part 5278). Storms within 50 miles would be monitored.

2) Limit access to the loaded shotholes about 1 hour prior to shot time with persons standing guard at the entrances to the field in which the shots would be detonated.

3) Turn off all radios and cell phones.

4) Reel out $\sim 500 \mathrm{ft}$ of shooting wire, which is shunted at our shooting box. (No powerlines are close enough to the testing site to be of concern.)

5) Test for stray currents, following Cal/OSHA Explosive Orders, Title 8, Group 18, Article 116, Part 5299.

6) Five minutes prior to shot time, attach the electrical blasting cap to the detonation cord and cover cap and cord with sandbags. Attach cap wire to shooting wire, insulating the connection from the ground.

7) Test the cap and shooting wire for continuity.

8) Check the area for presence of persons and use the signaling system recommended in Cal/OSHA Explosive Orders, Title 8, Group 18, Article 116, Part 5291.

9) Fire the shots using our specially designed shooting boxes, which receive Universal Greenwich Mean Time via a GPS receiver. When the shooting button is depressed, the box fires the shot on the upcoming minute mark. (We need to shoot on absolute time in order to calculate traveltimes of signals from our shotpoints to our seismographs.)

10) For a period of 5 minutes after the shot, no personnel would be allowed at the blast site until it is inspected and cleared by the Blast Officer. 
11) A misfire would be handled according to Cal/OSHA Explosive Orders, Title 8, Group 18, Article 116, Part 5293.

We would repeat this procedure for all three shotholes.

Our cleanup procedure would include one or more of the following:

1) We would expose the casing $2 \mathrm{ft}$ below ground surface, cut it off with a welding torch, and cap the hole.

2) Prior to the shot, we would remove a "stub" of casing a few feet long, that is not welded to the string of casing below it. This eliminates the need for excavation required in 1).

3) In all cases, we would return the site to as near its original condition as possible. In $\sim 90 \%$ of our shots, there is no disturbance of the surface. In the other $\sim 10 \%$, the casing may be pushed up (1-10 ft) and/or there may be a small slump crater in the immediate vicinity of the shothole. We would fill in any such disturbances with off-site material.

Our Preliminary Environmental Assessment has additional details, including FAQ's.

To expose the drain tiles near our test holes for observation purposes, we propose to dig one or more trenches near our test shotholes, using a combination of backhoe and hand shoveling. We would use proper shoring of trenches more than $5 \mathrm{ft}$ in depth (Cal OSHA Construction Safety Orders, Section 1541.1). We would rope off the trenching area. We would examine and photograph the drain tiles after each test shot. Finally, we would restore the trenched area to as near its original condition as possible.

We appreciate your taking time from your schedule to consider this proposal. We have always enjoyed and benefited from working with Caltrans.

Yours truly,
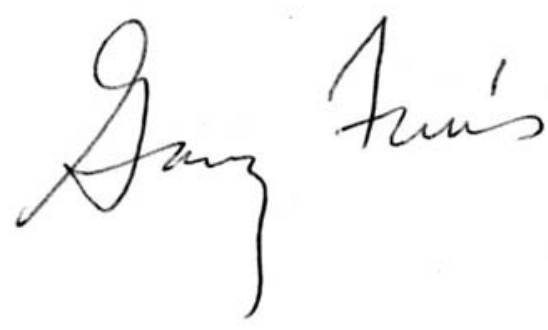

Gary Fuis, Geophysicist

U.S. Geological Survey

345 Middlefield Rd.

Menlo Park, CA 94025

Ph. 650-329-4758

Fax 650-329-5163

fuis@usgs.gov 
Appendix 2b. CalTrans Encroachment Permit 


\section{STATE OF CALIFORNIA - DEPARTMENT OF TRANSPORTATION ENCROACHMENT PERMIT TR-0120}

In compliance with (Check one):

$\triangle$ Your application of $\quad$ March 10,2009
Utility Notice No.

Agreement No.

R/W Contract No.

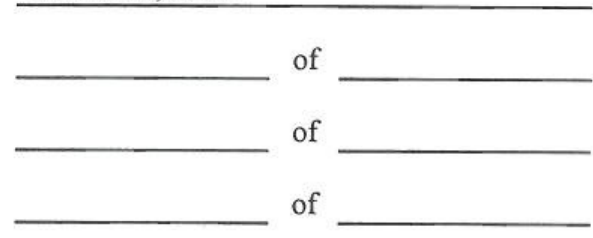

TO:
Permit No.

0409-NSV0340

Dist/Co/Rte/PM

All Districts-VAR-VAR-VAR VAR

Date

March 11, 2009

\begin{tabular}{|l|l|}
\hline $\begin{array}{l}\text { Fee Paid } \\
\$\end{array}$ & $\begin{array}{l}\text { Deposit } \\
\$\end{array}$ \\
\hline Performance Bond Amount (1) & Payment Bond Amount (2) \\
\hline Bond Company & \\
\hline Bond Number (1) & Bond Number (2) \\
\hline
\end{tabular}

United States Geological Survey
345 Middlefield Road
Menlo Park, CA 94075
$\begin{array}{ll}\text { Attn: } \quad \text { W. Karl Gross } \\ \text { Phone: } & \text { (650) 329-4133 }\end{array}$

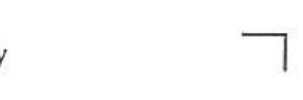

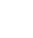

and subject to the following, PERMISSION IS HEREBY GRANTED to:

Conduct geological, hydrological and biological investigations; and perform rock deformation surveys, and other scientific research investigations on various State Highways at various Post Mile locations with the State of California.

A minimum of one week prior to the start of work under this permit, notice shall be given to, and approval of construction details, operations, public safety, and traffic control shall be obtained from the State Representative listed on page 2 of this permit.

All permitted work requires the permittee to apply for and obtain a work authorization number prior to the start of work. See the attached "Encroachment Permit Project Work Scheduling Procedures" and the attached "Permit Project Work Scheduling Request Form". Additional time beyond the minimum seven days advanced notice required in the above paragraph may be required for obtaining approval for the traffic control.

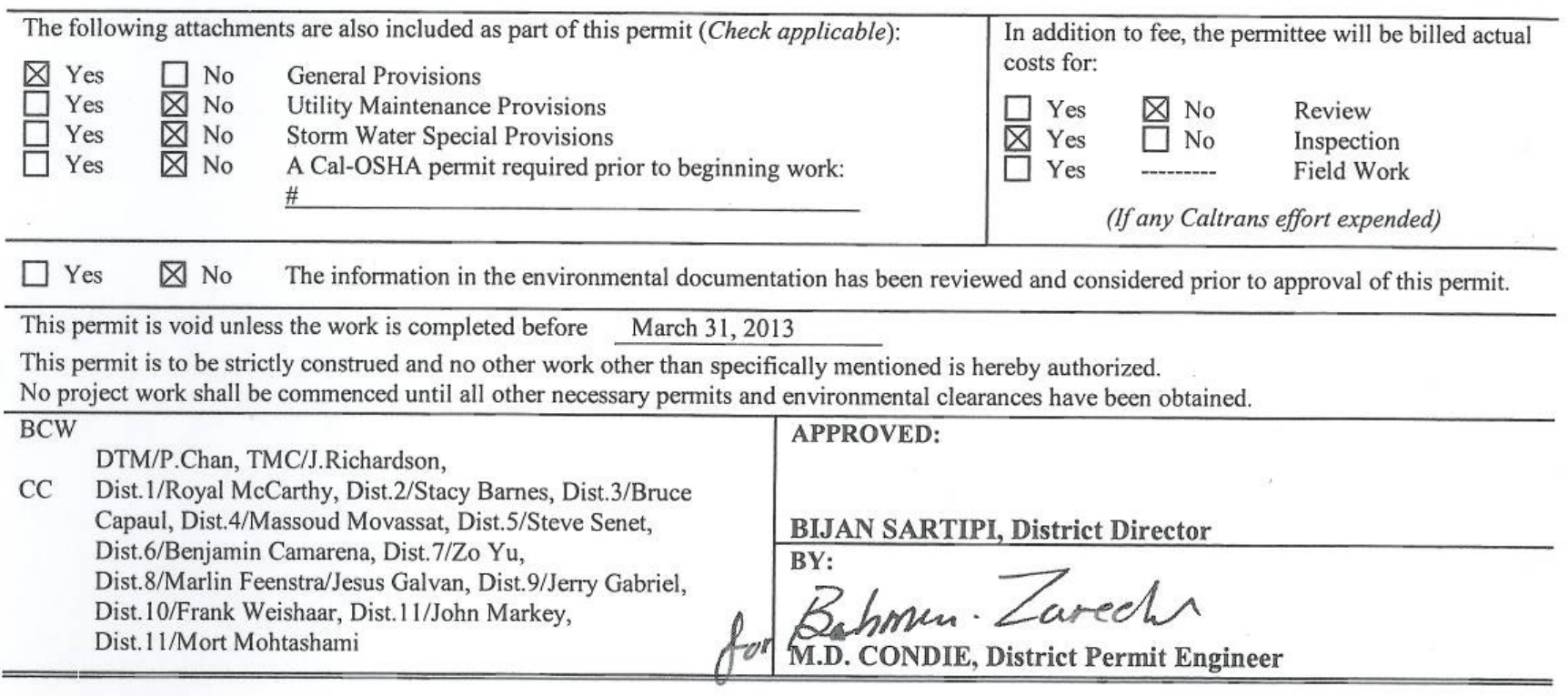


NAME: United States Geological Survey

PERMIT NO: 0409-NSV0340

DATE: $03-11-2009$

$\begin{array}{llll}\text { District 1 } & \text { Eureka } & \text { Royal McCarthy } & (707) 445-6389 \\ \text { District 2 } & \text { Redding } & \text { Stacy Barnes } & (530) 225-3314 \\ \text { District 3 } & \text { Marysville } & \text { Bruce Capaul } & (530) 741-4403 \\ \text { District 4 } & \text { Oakland } & \text { Masssoud Movasat } & (510) 286-3152 \\ \text { District 5 } & \text { San Luis Obispo } & \text { Steve Senet } & (805) 549-3152 \\ \text { District 6 } & \text { Fresno } & \text { Benjamin Camarena } & (659) 445-6578 \\ \text { District 7 } & \text { Los Angeles } & \text { Zo Yu } & (213) 897-8498 \\ \text { District } 8 & \text { San Bernardino } & \text { Martin Feenstra } & (909) 383-4626 \\ & & \text { Jesus Galvan } & (909) 383-4017 \\ \text { District } 9 & \text { Bishop } & \text { Jerry Gabriel } & (760) 872-0650 \\ \text { District } 10 & \text { Stockton } & \text { Frank Wishaar } & (209) 948-3819 \\ \text { District } 11 & \text { San Diego } & \text { John Markey } & (619) 688-6158 \\ \text { District } 12 & \text { Orange County } & \text { Mory Mohtadhami } & (949) 724-2525\end{array}$

When approved, traffic control performed under this permit shall be in accordance with the appropriate State Standard Plans T-10 through T-14. Where required by the plan, the use of a flashing arrow-board is MANDATORY.

Traffic control is restricted to closure of shoulder between 9 AM and 3 PM, Monday through Friday, holidays excepted. See attached Standard Plan T-10.

When survey operations are being conducted, the permittee shall furnish, place and maintain required signs, safety equipment in accordance with the latest edition of the "Manual of Traffic Controls for Construction and Maintenance Work Zones."

Permittee's personnel shall wear hard hats and lime green vests, shirts, or jackets with retro-reflective material and safety glasses and shall carry appropriate U.S. Department of Interior identification card.

The site of the work shall be enclosed by suitable barricades, signs and lights, as approved by State's representative, to warn and protect traffic effectively.

Any damage to existing facilities, landscaping or irrigation within the State's Right of Way shall be replaced in kind by the Permittee at Permittee's expense.

Any collected survey data requested by Caltrans shall be furnished to Caltrans free of charge.

Any painted markings shall be made with water-soluble paint.

Survey information and assistance maybe obtained upon request to: Survey Section, Department of Transportation, P.O. Box 23660, Oakland, CA 94623-0660.

SURVEY WORK IS PROHIBITED ON FREEWAYS.

Darra ? of? 
-

STATE OF CAIIFORNA, DEPARTMIEYT OF TRANSPORTATION

ENCRO ACFMEVT PERMIT GENERAI PRDVISIONS

TR-0045 (REV.0S/2007)

1. AETHORITY: The Department's authority to issue encroachment permils is provided under, Div. 1, Chipt 3, Arr 1, Scct. 660 to 734 of the Sreets and Fighways Code.

2. REVOCATION: Encroachment permits are revocable on five days notice unless otherwise stated on the perntit and except as provided by law tör public corporations, franchise holders, and utilities. Thete General Provisions and the Fincroschmont Pcrmit Utility Proyisions are strbjecl to modification or abrogation at any timc. Permittces' joint use agreements, franchise rignts, teacrved rights or any other agreements for operating purposes in State highway right of way are exceptions to this revocation.

3. DENIAL FOR NONPAYMENT OF FEES: Failure to pay permit fees when due can result in rejection of future applications and denial of pernits.

4. ASSIGNMENT: No party ather than the permittce or permittee's authorized agent is allowed to work under this permit.

5. ACCEPTANCE OF PROVISIONS: Permittee understands and itgrets to uccept these General Provisions and all attachments to this perrnit, for any work to be performed under this perrit.

6. BECINNING OF WORK: When traffic is not impacted (see Number 35), the permittec shall notify the Department's representative, two (Z) days before the intent to start permitted work Petrnittee sball notify the Department's Representative if the work is to be interrupted for a period of five (5) days or more, unless otherwisc agrecd upon. All work shall be performed on weekdays during regulsr work hours, excluding holidays, unless otherwise specified in this pertsit.

7. STANDAKDS OF CONSTRUCTION: All work performed within highway right of way shall conform to recognized construction standards and current Department Standard Specifications, Department Standarrd Plnns High and Low Risk Facility Specifications, and Utility Specisl Provisions. Where reference is made to "Contractor and Engineer," these are amended to be read as "Pcrmittee and Department representative."

8. PLAN CHANGES: Changes to plans, specifications, and permit provisions are not allowed without prior approval from the State representative.

9. INSPECTRON ANYD ARPROVAE: All work is subject to monitoring and inspection. Upon completion of work, permittee shall request a final inspection far acceptance and approval by the Department. The local agency permittee shall not give fins construction approval to its contractor until final scceptance and approval by the Department is obtained.

10. PERMIT AT WORKSTTE: Permittee shall keep the permit pacicage or a capy thereof, at the work site and show it upon request to any Department representative or law enforcement officer. If the permit packnge is not kept and msde avsilable st the work site, the work shall be suspended.

11. CONFLICTIYG ENCROACHMEITS: Permittee shall yield start of work to ongoing, prior authorized, work adjucent to or within the limits of the project site. When existing encroachments conflict with new work, the permittee shall bear all cost for rearrangements, (e.g., relocation, sitcration, removal, etc.).

12. PERIMITS FROM OTHER AGENCIES: This permit is invalidated if the permittee has not obtained all permits necessary and required by law, from the Public Utilities Commission of the State of Caliromia (PUC), California Occupalional Safety and Hcaith Administration ( $\mathrm{C}$ al-OSHA), or my other public agency having jurisdiction.

13. PEDESTRIAY AND BICYCLIST SAFETY: A safe minimum passagcway of 4' shall be maintained through the work arca at cxistin? pedestrian or bicycle facilitics. Ac no time shall pedestrians be diverted onto a portion of the strect used for vehicular taffic. At locations where safe ialternate passageways camnot be provided appropriate signs and barricades shall be installed at the limits of construction and in advance of the limits of construction at the nearest crosswalk or intersection lo detour pedestrians to facititics across the strct. Artention is directed to Section 7-1.09 Public Sefcty of the Department Standard Specifications.

14. PUBLIC TRAFFIC CONTROL: As required by law, the permittee shall provide traflic control protection warning signs, lights, safely doviccs, ctc., and take all other measures neceskary for traveling public's bafety. While providing traftic control, the needs and control of all road users fmotorists, bicyclists and pedestrians, including persons with disabilities in accordnnce with the Amcricans with Disabilities Act of 1990 (ADA)] shall be an essential part of the work activity.

Day and right time lane closures shall comply with the Catifornia Marual on Unifum Traffic Control Devices (Part 6. Temporary Trafic Control), Standard Plans, and Standard Specifications for traflic control systems. These Gencral Provisions are not intended to impose upon the permitlee, by third partics, any duty or standard of care, grcaster than or different from, as required by law.

15. MINLMUM INTERFERENCE WITH TRAFTIC: Pennittee shall plan and conduct work so as to create the least possible inconvenience to the traveling public: traflic shall not be unreqsonably delayed. On conventional highways, permittee shall place properiy attircd flagger(s) to stop or warn the traveling public in compliance with the California Mamual on Uniform Traflic Control Devices (Chapter $O E$, Flagger Control).

I6. STORAGE OF EQUTPMENT AND MATERIAIS: The storage of equipment or mnterials is not allowed within State highway right-ofway, unless specifled within the Special Provisions of this spccific encroachment permil. If Encroachment Permit Spccial Provisions allow for the storage of equipment or materials within the State right of way. the equipment and matcrisi storage shail comply with Standard Specifications, Standard Plans, Special Provisions, and the Highway Design Manual. The clear recovery zonc widths must be followed and are the minimum desirable for the type of facility indicated below: freeways and expressways $-30^{\prime}$, conventional highwsys (no curbs) $-20^{\prime}$, conventional highways (with curbs) - 1.5\%, If a fixed object cannot be eliminated, moved ourside the clear recovery zone, or modificd to be made yielding, it should be shieddec by a guardrail ar a crash cushion.

17. CARE OF DRAINAGE: Permittee shall provide altemate drainage for any work interfering with an existing drainage fscility in compliance with the Standard Specifieations, Standard Slans and/or as directed by the Department's representative.

18. RESTORATION AND REPAIRS IN RYGHT OF WAY; PETItTEE is responsible for restoration and repair of State highway right of way resulting from permilted work (State Streets and Highways Cadc, Sections 670 et. seq.). 
19. RUGET OF WAY CLEAY UP: Upon completion of work, permiltee shall remove and dispuse of all scraps, brush, dimber, materials, etc. off the right of way. The sesthetics of the higinway shall be as it was before work started.

20. COST OF WORK: Unless staced in the petmit, or a scparite written agreement, the pcrmittee shall bear all costs incurred for work within the State rigit of way and waives all claims for indemnification or contribution from the State.

21. ACTUAL COST BILLING: When speciffed in the permit, the Department will bill the permittes actual costs at the currently set hourly rate for encroachment permits.

22 AS-BULT PLAiVS: When required, permitce shall submit one (l) set of [olded as-built plans within thirty (30) days after completion and approval of work in compliance with requirements ligted as toillows:

1. Upon corrmiction of the waric provided herein, the permittes shall send one vellum or paper set of Ass-Built pians, to the State representative. Mylar or paper sepia plang are not acceptablc.

2. All changes in the work will be shown on the plans, as issucd with the permit, including changes approved by Encroachment Permil Rider.

3. The plans are to be stamped or otherwige noted AS-BUILT by the perrrittee's representative who was responsible for overseeing the work. Any original plan that was approved with a State stamp, or Caltrans representative signature, shall be used for producing the As-Built plans.

4. If As-Built plans include signing or striping, the dates of signing or striping removal, relocation, or installation shall be shown on the plans when required as a condition of the permit. When the construction plans show signing and striping for slaged construction on separate sheets, the sheet for exth stage shall show the removal, relocation or installation dates of the sppropriate staged striping and signing

5. As-Built plans shall contsin the Permic Number, County, Route, and Post Mile on each shect.

6. Disclsimer statement of any kind that differ from the abligations and protections provided by Sections 6735 through 6735.6 of the California Business and Professions Code, shail not be included on the As-Built plans. Such statements constitule non-compliance with Encroschment Permit requirments, and may result in the Department of Transportation retaining Performance Bonds or deposits until proper plans are subirritted. Failure to comply may siso result in denial of future permits, or a provision requiring a public âgency tus supply additionai bonding.

23. PERMTTS FOR RECORD PURPOSES ONY, Y: When work in the right of way is wilhin an grea under a Joint Use Agreement (JUA) or a Consent to Common Use Agrement (CCUA), a fee exernt permit is issucd to the permitter for the purpose of providing a notice and record of work. The Permittee's prior rights shall be preserved without the intention of creating new or different rights or obligations. "Natice and Reeord Purposes Oniy" shall be stamped across the face of the permit.

24. BONDTYG: The permittee shall fle bond(b), in advance, in the arrount set by tha Department. Failure to maintain bond(s) in full force and effect will result in the Department stopping of all work and revolaing permit(s). Bonds are not required of public corporstions or privately owned utilities, unless permittee fisiled to comply with the provision and conditions under a prior permic. The surety cormpany is responsible for any latent defects as provided in Californiz Code of Civil Procedures, Section 337.15. Local agency permittee shall comply with requirements established as follows: In recognition that preject construction work donc on State property will not be directly funded and paid by State, for the purpose of protecting stop notice claimants and the interests of State relative to successful project completion, the local agency pcrmituee aprees to require the sonstruction contractor furmish both a payment and perfomince bond in the local agency's name with both bonds complying with the requirements set forth in Section 3-1.02 of State's currenl Standard Specifications bcfore performing any project contstruction Siandard local agency permittec shall defend, indermify, and hold harmicss the State, its officers and employces from all project construction ralated claims by contractors and all stop notice or mechanic's lien claimants. The local agency also agrees to remcdy, in a timely manner and to State's satisfaction, any latent defects occurring as a result of the project construction work.

25. RUTURE MOVING OF INSTALLATIONS: Permillee undicrstands and agrees to relncate a permitted installation upon notice by the Department. Unless under prior property right or agreement, the permittec shall comply with said notice at his sole expense.

26. ARCHAEOLOGICAL/HISTORICAL: If any archeeological or historical resources are revealcd in the work vicinity, the permictec shall immediately stop work, notify the Department's representative. retnin a qualified archaeologisl who shall cvaluate the site, and make recommendations to the Department representative regarding the continuance of work.

27. PREVAILING WAGES: Work performed by or under a permit may require permiltee's contractors and subcontractors to pay appropriate prcvailing wages as set by the Department of Industrial Retations. Inquiries or requests for interpretations relative to enforcement of prevailing wage requirements are directed to Slate of cialitornia Department of Industrial Rciations, 525 Golden Gare Avenue. Ssr Francisco, Califomia 94102

28. RESPONSIBILITY FOR DAMAGE: The State of California and all officers and ermplayecs thcreof, including but not limited to the Dircctor of Transportation and the Depuly Director, shall not be answcrable or accountable in any manner for injury to or death of uny person, including but not limited to the permittee, persons employed by the permittece, persons acting in bchalf of the permittec, or for damage to property from sny cause. The permittec shall be responsible for any liability imposed by law and for injuries to or death of any person, including but not limited to the pernittec, persons employed by the permittee, persons acting in behalf of the permittec, or for damage to property arising out of work, or ather activity perrmitted and done by the permittee under a permit, or arising out of the failure on the permitte's part to perform his obligations under any permit in respect lo maintenance or any other abligations, or resulting from defects or obstructions, or from any csusc whatsoever during the progress of the work, or ocher activity or at any subsequent time, work or other activity is being performed under the obligations provided by and contemplated by the perrnit.

The permitte shall indemnify and save harmless the Slate of Cslifornia, all officers, cmployees, and Sture's contractors, thereof, including but not limited to the Director of Transpnrtation and the Deputy Director, from all clairns, suits or actions of every name, kind and description brought for or on account af injurics to or death of any person, including bul not limited to the permiltee, persons cmployed by the permittee, persons acting in behatf of the pernitlee and the public, or damage is property resuiting from the performance of work or other activity under the permit, or grising out of the failure an the permittee's part to perform his obligations under any permit in respect to maintenance or uny other obligations, or resulting from defects or obstructions, or from uny causc whatsoever during the progress of the work, or other activity or at any subsequent time, work or other activity is being perfornted under the obligntions provided by and contemplated by the permit, except as atherwise provided by statute. 
The duty of the permitee to indernify and suive harmless includes the duties to defend as sct forth in Section 2778 of the Civil Code. The permitue waives any and all rigits to any type of expressed or implied inderrenity againat the State, its officcrs, cmployces, and State contractors. It is the intent of the parties that the permitte will indemnity and hold harmiless the State, its officers, ermployees, and State's contractors, from any and all claims, suits or actions as set forth sbove regardless of the existence or degree of fault or ncglizcnce, whether active or passive, primary or secundary, on the part of the Statc, the pcrmitice, pcrsons emplayed by the permittes, of scuing on bchalf of the permittee.

For the purvose of this section, "State's contractors" shall include contractors and their subcontractors under contract to the State of Cat ifomia performing work within the limits of this permit.

29. NO PRECEDENT ESTABLISHED: This permit is issucd with the understanding that it does not establish a precedent

30. FEDERAL CIVIL RIGHTS REQUIREMENTS FOR PUBLIC ACCOMMODATLON:

A. The permittce, for himsclf, his personal representative, successors in interest, and assigns as pari of the considerntion hereof, does hereby covenant and agrce that:

1. No person on the grounds of racc, color, or national origin shall be excluded from participation in, be denied the benefits of, or be alherwise subjected to discrinination in the usc of said facilities.

2. That in comrection with the canstruction of any improvements on said lands and the fumishings of services thereon, na discrimination shall bc practiced in the selection and retention of first-tier subcontractors in the selection of second-ticr subcontractors.

3. That such discrimination shall not be practiced agginst the public in their accoss to and use of the facilities and services provided for public accommodations (such as cating, siccping, rcst, recrcation), and operation on, over, or under the space of the right of way.

4. That the permiltee shall use the prenises in compliance with atl other requirements imposed pursuant to Title 15, Code of Federal Ragulations, Commerce and Foreign Trade, Subtitle $\Lambda$. Office of the Secratary of Commerce, Part 8 (15 C.F.R. Part 8) and as said Regulations may be amended.

5. That in the event of breach of any of the above nondiscrintination covenants. the State shall have the right to terrminate the perrnit and to ro-enter and repossess said land and the land and the fucilities thereon, and hold the same as if gaid permit had never becn made or issued.

31. MAINTENANCE OF HIGHWAXS: The permittee agrees, by seceptance of a permit, to properly maintain any encroachunent. This assurence requires the permittec to provide inspection and repair any darnage, at pertutittee's expense, to State facilitics resulting from the encroschment.

32. SPECIAL EVENTS: In accordance with subelivision (s) of Streets and Highways Code Section 682.5. the Department of Transportation shall not be responsible for the conduct or operation of the permitted activity, and the applicant agrees to detend, indermify, and hold harmless the Stale and the city or county agsinat any and all claims arising out of any activity for which the permit is issued.

Permittce understands and agrees that it will comply with the obligations of Titles II and III of the Americans with Disabilitics Act of 1990 in the conduct of the event, and further agrees to indermify and save harmless the State of California, all officers and employees thereof, including but not limited to the Director of Transportation, from any claims or liahility srising ous of or by virtue of said. Act.

33. PRTVATE USE OE RIGHT OF WAY: Highwsy right of way shail nat be used for private purposes without compensation to the Strte.
The giñing of public property use and therefore pubiic funds is prohibited under the Califomia Constitution, Articie 16

34. FLELD WORK REMMBURSEMENT: Permiltes shall reimoursc State for field work performct on permittee's behalf to correct or remedy hazards or darnaged facilitics, or clcar dicbris not attended to by the permittec.

35. NOTIFICATION OF DEPARTMENT AND TMC: The permitte shall nocify the Department's represcntative and the Transportation Management Center (TMC) at least 7 days beforc initiating a lane closure or conducling an activity that may causc a traftic impact. A confirmation notification should oceur 3 days bcfore closure or other potential traffic impacts. In emergency situations winen the cortcetive work or the emergency itself may affect traffic, TMC and the Department's representative shall be notified as soon as pcassïble.

36. SUSPENSION OF TRAFFIC. CONTROL OPERATION: The pcrmittec, upon notification by the Department's representativc, shall inmediately suspend sit lane closure operations and any operation that impedes the flow of traffic. All costs $23 s$ ociated with this suspension shall be torne by the permittee.

37. UNDERGROUND SERVICE ALERT (USA) NOTIFICATION: Any excavation requires compliance. with the provisions of Government Code Section 4216 et. seq., including, but not timitcd to notice to a regional notitication center, such as Undergraund Service Alert (USA). The permittee shall provide notification at least 48 hours befure performing any excavation work within the right of way. 


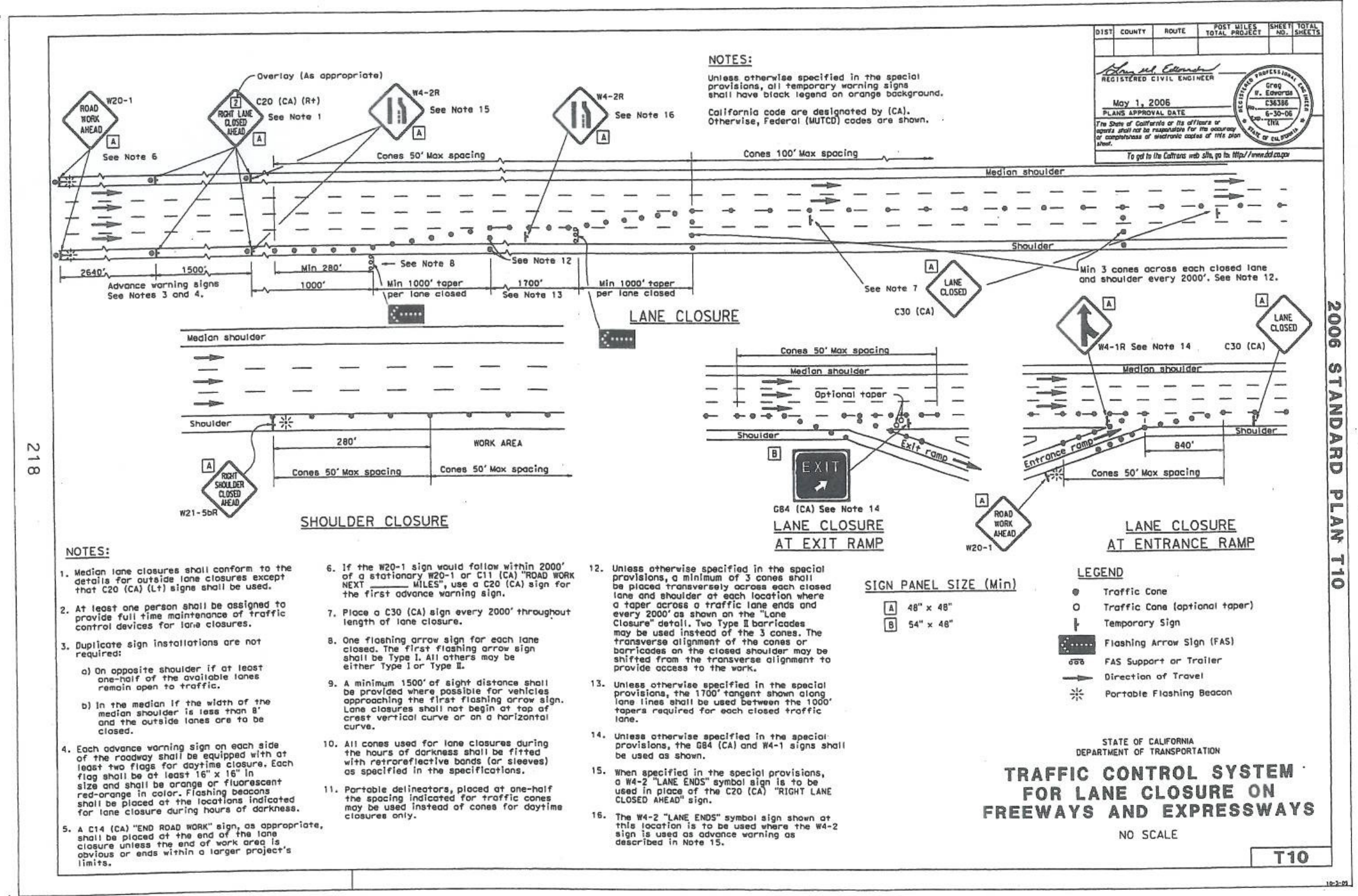


Encroachment Permit Work Scheduling Request Form

Submit request to schedule traffic control weekly, 7 days in advance, using this form. Submit to Permit Duty Station by FAX, 510-286-3960, or E-mail: Permit_Duty_Engineer@dot.ca.gov. Reminder! - Notify Inspector listed on page 1 or 2 of your Permit. Check Permit Special Provisions for authorized work hours. Any deviation from the Permit must be requested in writing. INSTRUCTIONS AND ABBREVIATIONS: See Procedures on reverse of this form (page 2).

1. Permit No.: 2.Expiration Date:

3. Request Date:

4. Caltrans Inspector: 5. Requested Work Week:

to

6. Route: 7. County:

8. City or township:

9. $\square$ PostMiles or $\square$ Kilopost: From: To: 10. Existing Lanes (in each Dir): Dir Lns / Dir Lns

11. Describe Location (use landmark if necessary): From: To:

12 Name of Conventional Highway or Surface St:

13. (a through $\mathrm{k}$ ) Fill in or ' $\mathrm{x}$ ' if applicable: (a) $\square$ Divided Hwy or $\square$ Undivided Hwy (b) $\square$ Full-Closure $\square 1$ dir or $\square$ both dir

(c) $\square$ One-way Traffic Control: Only on "Undivided" Hwy (Alternate use of same lane for both directions--hold trfc 5-10 min wiflaggers)

(d) $\square$ Connector Ramp: (State Highway \#) to (State Highway \#) Closed $\square$ or Lane\#

(e) $\square$ Off/ramp: (Freeway to City St) Ramp Name: Off/ramp Closed $\square$ or Lane\#:

(f) $\square$ On/ramp: (City St to Freeway) Ramp Name: On/ramp Closed $\square$ or Lane\#:

(g) $\square$ Divert Trfc or Contra Flow: Reconfigure lanes/divert trfe to Lane\#_ in the __ Direction; _L Lane(s) open ea direction.

(h) DIntermittent Traffic Control (i) DVarious Locations (j) DL Long-Term (24 hours continuous) ETO

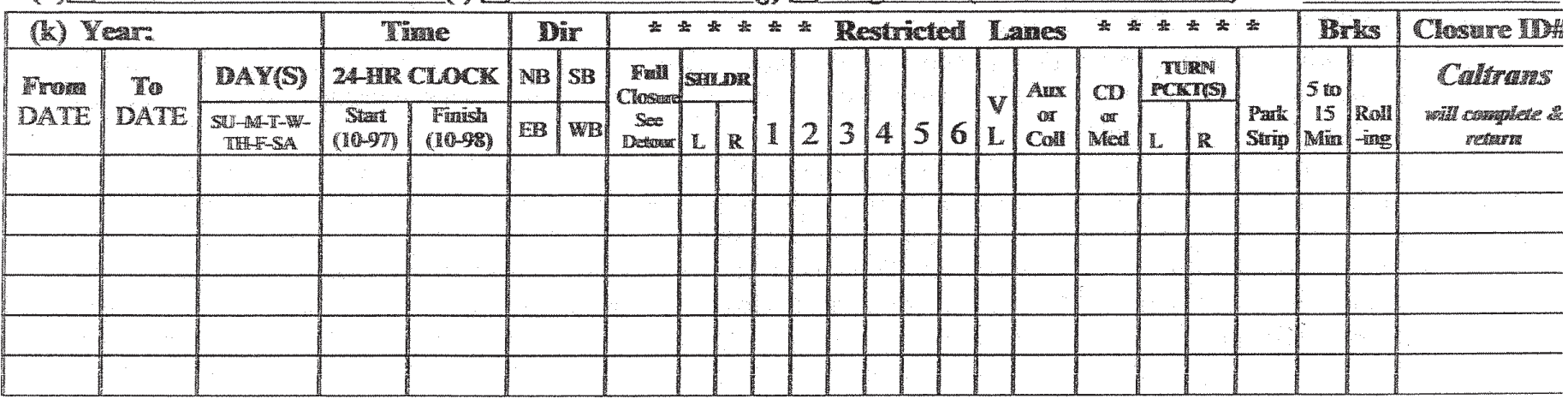

14. Description of work/comments:

15. Detour (Required for full closure):

16. Contingency Plan:

17. On-site during work (circle if applicable) CHP / PD / Other:

\begin{tabular}{|c|c|c|}
\hline 19. Name: & Penmittee: & Contractor (if differeat tham permittiec): \\
\hline \multicolumn{3}{|l|}{ Address: } \\
\hline \multirow{4}{*}{$\begin{array}{l}\text { On-site } \\
\text { Personnel } \\
\text { Contact } \\
\text { Name(s) } \\
\& \\
\text { Phone No. }\end{array}$} & Name: & Name: \\
\hline & Ofice: & Office: \\
\hline & Celf: & Cell: \\
\hline & FAX: & FAX: \\
\hline
\end{tabular}

19. "REAL-TIME" STATUS INSTRUCTIONS - PLEASE MAKE YOUR FIELD PERSONNEL AWARE \& RESPONSIBLE!

Permittee shall STATUS scheduled work DAILY via Caltrans 24-Hour Communication Center at 510-286-6359. Status using Closure ID No(s) at the start of work, (10-97), and again when work is finished for the day, (10-98). To cancel (10-22), phone 510-286-6359 or fax to 510-286-6358 before the scheduled 10-97 time, but no later than 1 hour prior to the scheduled 10-98 time. Any delay in picking up your closure must be reported immediately to 510-286-6359 or Permit Inspector. See item 9 on reverse/page 2 . 
1. INSTRUCTIONS: Fill in blanks or check appropriate boxes. Attach maps or diagrams, if available. Enter beginning day through ending day of work week (M-T-W-TH-F-SA-SU). Month/Day: Enter month (1-12) and day (1-31) of requested week. Start \& Finish Time: Use 24 hour clock format. Read page 2 of your Permit Special Provisions for hours \& days allowed. Separate lane closure \#'s are required for each direction and facility. Use separate line for each. Lanes are numbered in direction of travel from left to right, excluding turn pockets; left being \#1 or "fast lane". Check boxes under RESTRICTED LANES to indicate lanes or parts of highway to be closed. "VL"(Various Lanes) may be checked with note in Comments Section stating number of lanes to remain open at all times.

2. ABBREVIATIONS: Aux=auxiliary, $\mathbf{C D}=$ Center Divide; Coll=Collector; Conn=Connector; Contra Flow=Close 1 direction of traffic and divert to lane(s) in opposite direction or a turn lane. Day of Week=(M-T-W-TH-F-SA-SU); Dir=Direction (NB=North, $\mathbf{S B}=$ South, WB=West, or $\mathbf{E B}=$ East); $\mathrm{F} / \mathrm{L}=$ fog line; Lns=Lanes; $\mathrm{L}=\mathrm{Left}$; Med= Median; Off $/ \mathbf{R}=$ Off-Ramp; On/R=On-Ramp; Park Strip=Parking area parallel to lane; Pckt=Pocket; $\mathbb{R o l l}=$ Rolling (for closure such as sweeping); $\mathbf{R}=$ Right; Shld $r=$ Shoulder; $\mathrm{SR}=$ State Route; $\mathbf{V} / \mathrm{L}=$ Various Lanes; $\mathbf{V} / \mathrm{Loc}=$ Various Locations.

3. Requests for scheduling shall be submitted on this form via FAX to 510-286-3960, or, via E-Mail to Permit Duty_Engineer@dot.ca.gov, or, through the designated State Representative (page 1 of permit).

4. All permitted work (with or without traffic control) is subject to advance scheduling on this form, seven (7)days in advance of the work week requested. Submittals and approvals shall continue on a weekly basis.

5. If work begins weekly on Sunday, the work week shall be Sunday through Saturday. If work week begins on Monday, the work week shall be Monday through Sunday.

6. Incomplete, illegible, or inaccurate requests may be returned for correction. Assistance for completing the request may be obtained from the designated State Representative.

7. Every attempt will be made to return timely requests with closure ID or work authorization numbers, to the Permittee by close of business on Thursday, prior to the scheduled work week. When deemed necessary to ensure public convenience, Caltrans may deny and/or reschedule the request.

8. All requests must include a contingency plan for restoring public traffic (i.e. reopening of a closed lane, ramp and/or shoulder) in the event of (1) CHP or the local authority requires opening due to an unforeseeable incident in the nearby vicinity, or (2) permitted experiences an equipment breakdown, shortage of or lack of production materials or any other failure which would otherwise delay restoring public convenience within the time limits specified in the permit. The contingency plan shall include availability of any proposed standby equipment and stockpiled materials that can be utilized for the immediate opening of closures when ordered by the State representative. Acceptance of the contingency plan by the Engineer shall not relieve the Contractor from the requirement of opening the restricted travel way to accommodate public traffic as specified in the lane closure hour's section of the permit provisions.

9. Caltrans will review and process the request by entering all information into the State-wide Lane-Closure System (LCS). This process generates a work authorization number*. This number will be entered on the request form and returned to Permittee as approval to proceed AND will be used to "Real-Time Status" on a daily basis. Permittee shall communicate with Caltrans 24-hour District Communication Center (DCC) via telephone at $\underline{\text { 10-286-6359 }}$ twice daily when working, or once daily if cancelled.

a. When work begins (first cone down), Permittee shall contact Caltrans DCC and relay: "(Closure ID \#*) is 10-97".

b. When work ends (last cone removed), Permittee shall contact Caltrans DCC and relay: "(Closure ID \#*) is 10-98".

c. If the work is cancelled on any scheduled day, Permittee shall contact Caltrans DCC and relay;

"(Closure ID \#*) is 10-22". A "10-22" (cancellation) can be phoned at anytime before the scheduled "10-97" time, but no later than 1 hour prior to scheduled "10-98" time. You may be asked to fax confirmation of "10-22" to the DCC FAX at 510-286-6358.

d. During the work, any unexpected occurrences including delayed openings, accidents, etc., shall be communicated to Caltrans DCC@510-286-6359, immediately.

Avoid possible miscommunication when calling status. Use the PHONETIC ALPHABET to state your Closure ID: $\mathbf{A}=$ Adam, $\mathbf{B}=$ Boy, $\mathbf{C}=$ Charles, $\mathbf{D}=$ David, $\mathbf{E}=$ Edward, $\mathbf{F}=$ Frank, $\mathbf{G}=$ George, $\mathbf{H}=$ Henry, $\mathbf{I}=$ Ida, $\mathbf{J}=$ John, $\mathbf{K}=$ King, $\mathbf{L}=$ Lincoln, $\mathbf{M}=$ Mary, $\mathbf{N}=$ Nora, $\mathbf{O}=$ Ocean, $\mathbf{P}=$ Paul, $\mathbf{Q}=$ Queen, $\mathbf{R}=$ Robert, $\mathbf{S}=$ Sam, $\mathbf{T}=\mathrm{Tom}, \mathbf{U}=$ Union, $\mathrm{V}=$ Victor, $\mathbf{W}=$ William, $\mathbf{X}=\mathrm{X}$-ray, $\mathbf{Y}=$ Yellow, $\mathbb{Z}=$ Zebra. $\quad$ Example: P82CA="Paul 82 Charles Adam"

10. The intent of these procedures is to help ensure public convenience by identifying planned closures on the State Highway system, resolving potential conflicts, and disseminating all available "REAL-TIME" information, via the traffic media to all motorists, including but not limited to the public, CHP, local police and sheriffs' office, and emergency fire and rescue personnel.

* "closure ID number" is the same as "work authorization number" 
Appendix 3a. Near Source Acceleration Plots

[From 6-component RefTeks] 


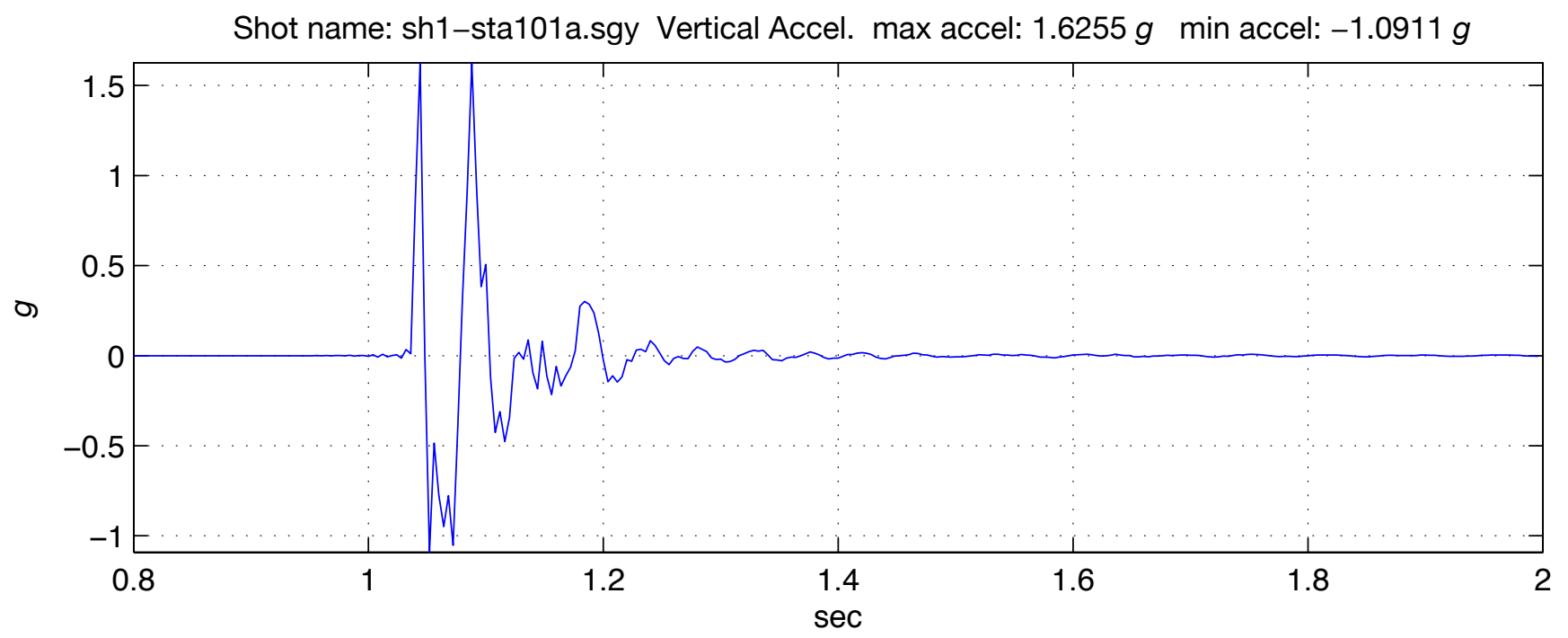

Shot name: sh1-sta101a.sgy Horizontal 1 Accel. max accel: $0.69566 \mathrm{~g}$ min accel: $-0.74289 \mathrm{~g}$

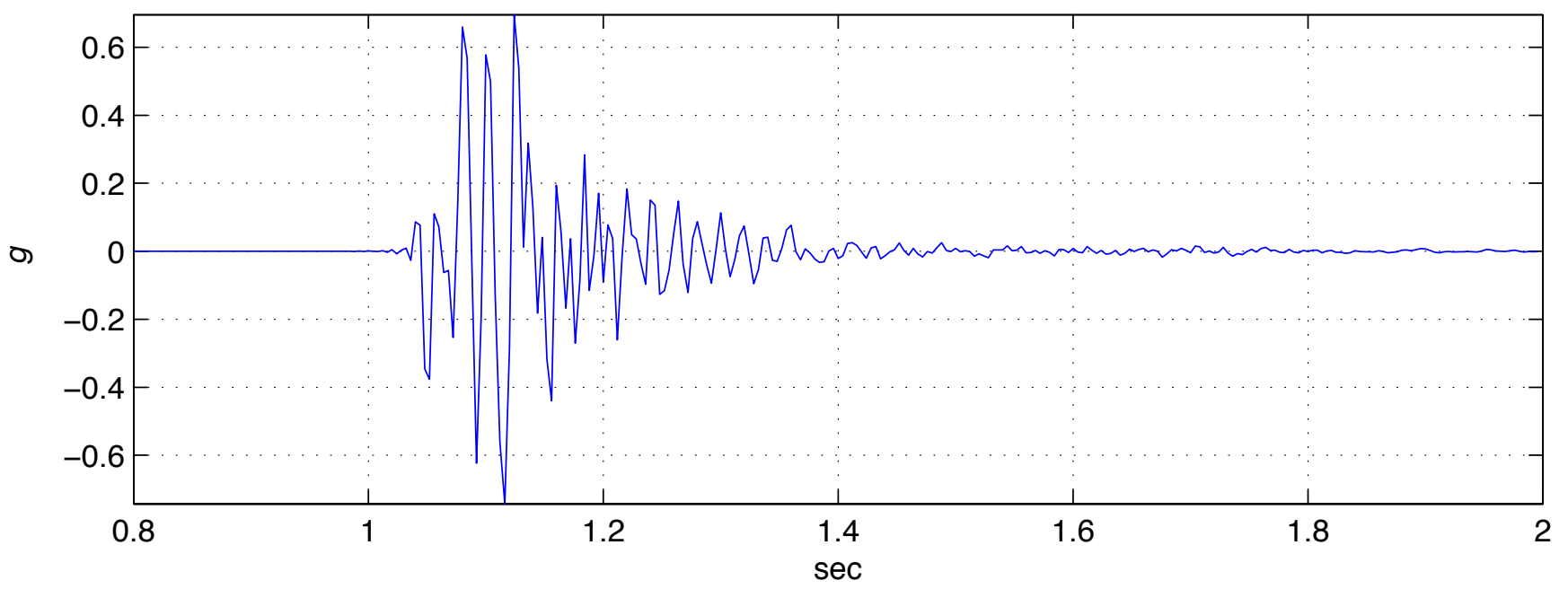

Shot name: sh1-sta101a.sgy Horizontal 2 Accel. max accel: $0.47302 \mathrm{~g}$ min accel: $-0.84929 \mathrm{~g}$

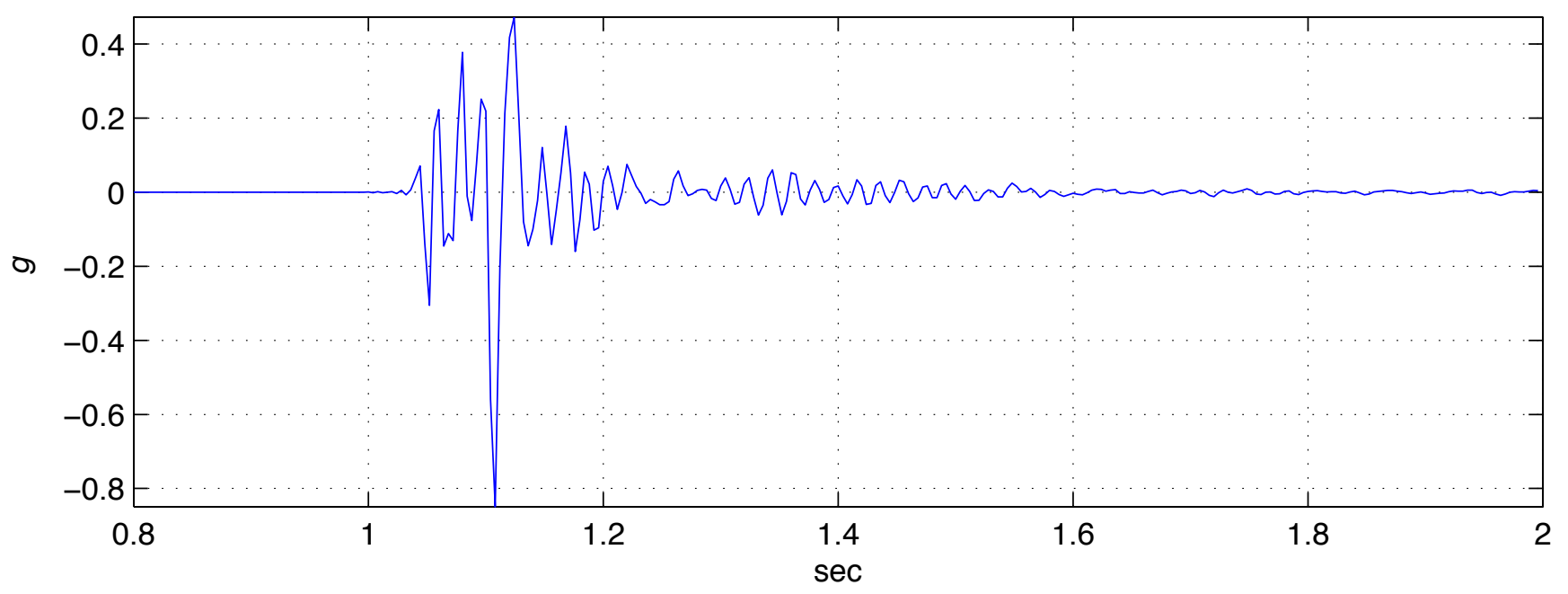


Shot name: sh1-sta102a.sgy Vertical Accel. max accel: $0.48902 \mathrm{~g}$ min accel: $-0.39874 \mathrm{~g}$

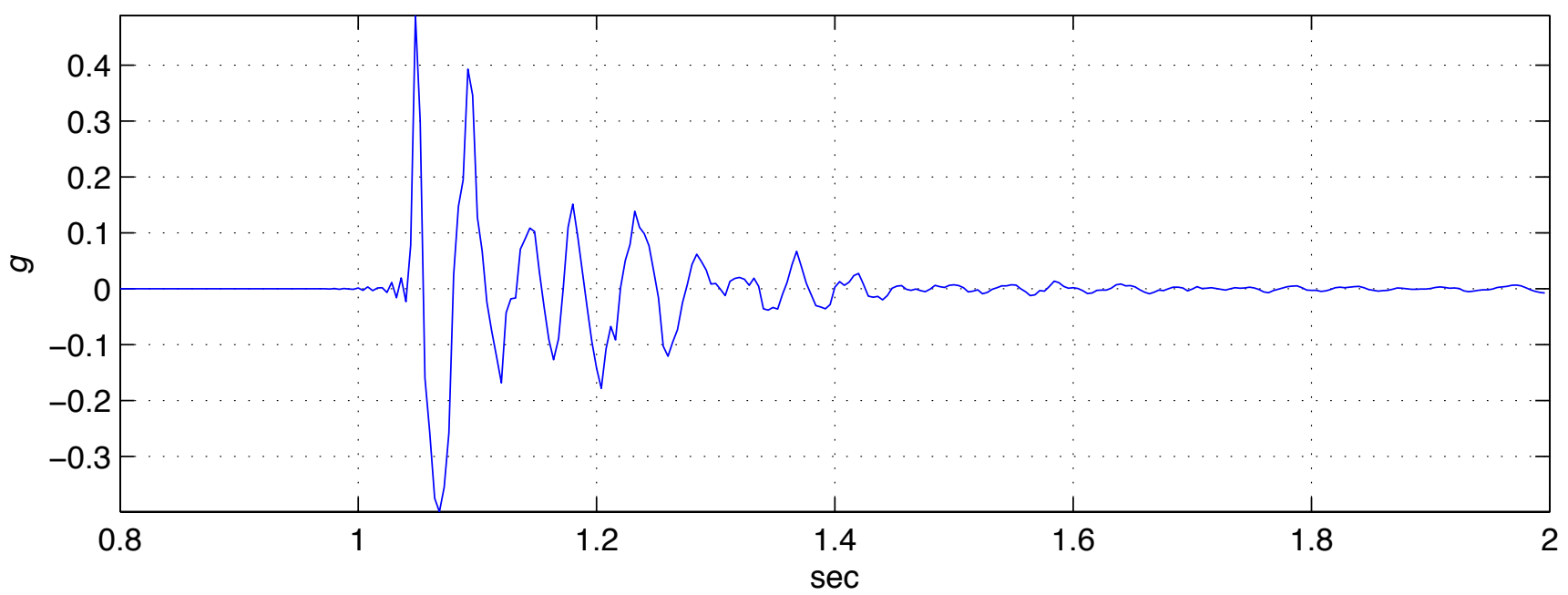

Shot name: sh1-sta102a.sgy Horizontal 1 Accel. max accel: $0.12193 \mathrm{~g}$ min accel: $-0.24299 \mathrm{~g}$

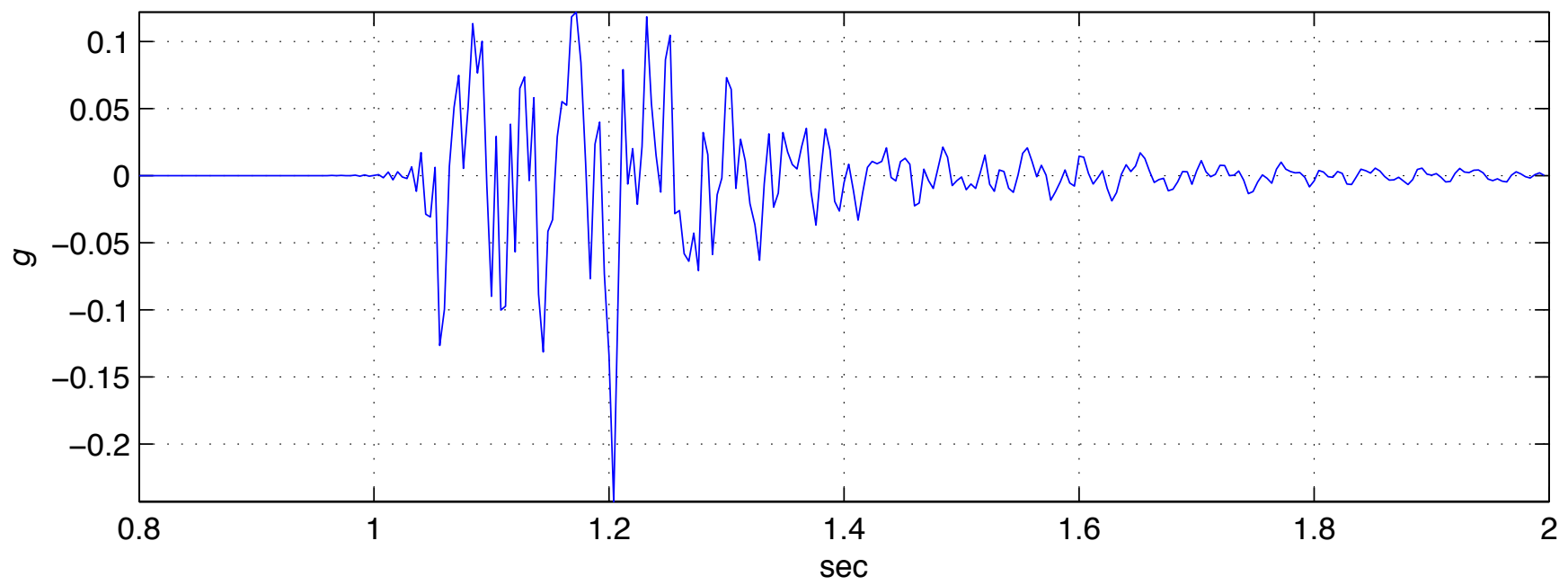

Shot name: sh1-sta102a.sgy Horizontal 2 Accel. max accel: $0.1873 \mathrm{~g}$ min accel: $-0.14032 \mathrm{~g}$

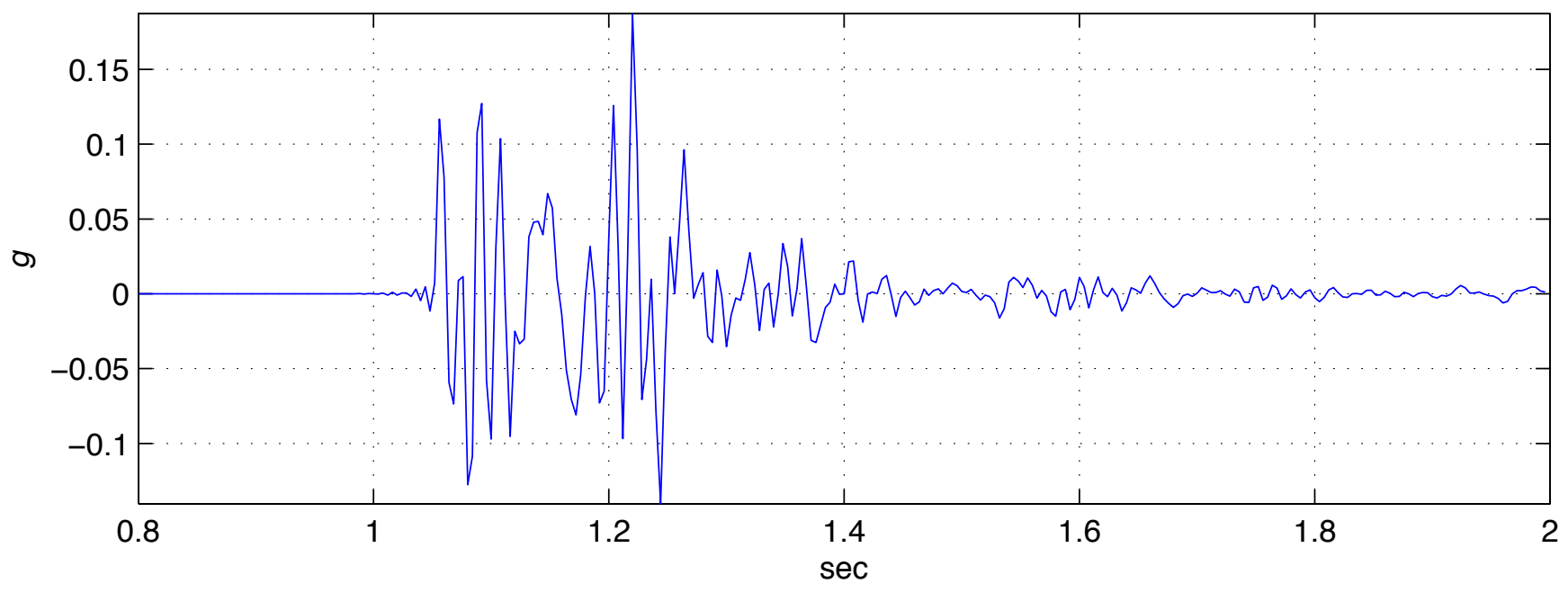




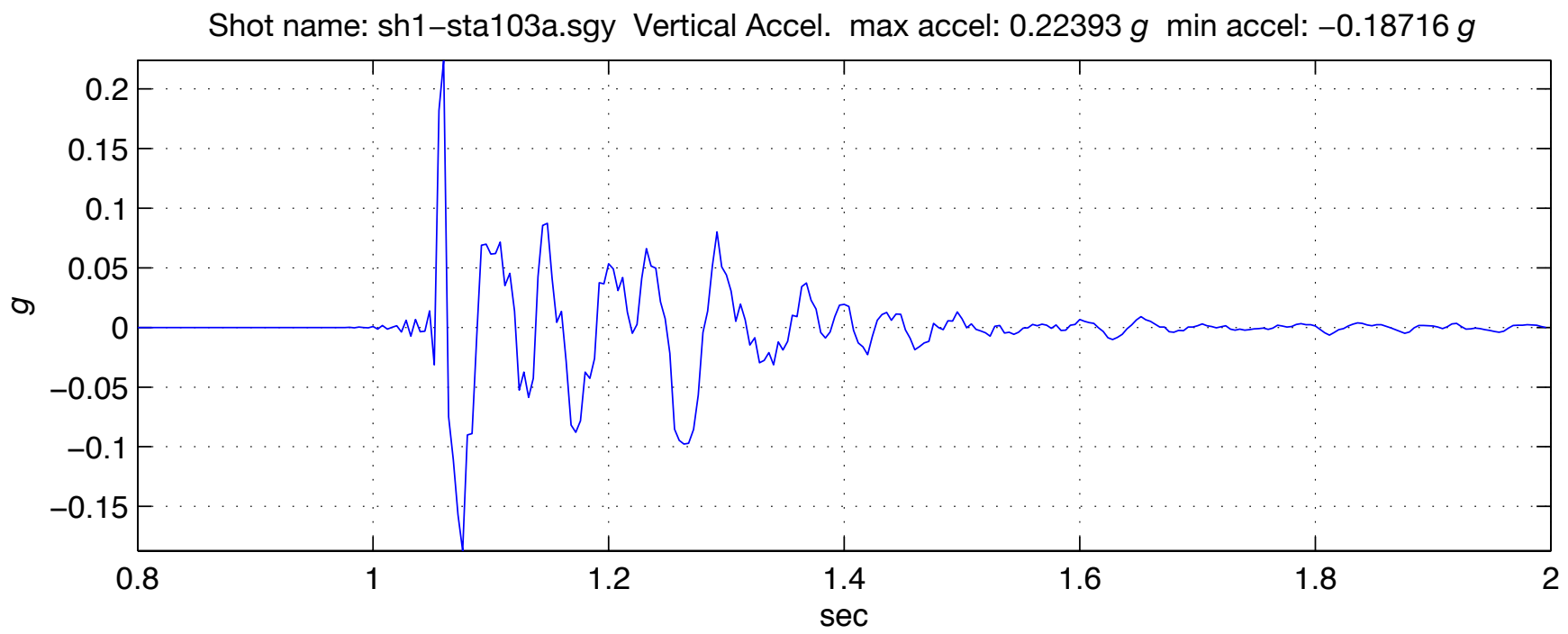

Shot name: sh1-sta103a.sgy Horizontal 1 Accel. max accel: $0.14291 \mathrm{~g}$ min accel: $-0.12585 \mathrm{~g}$

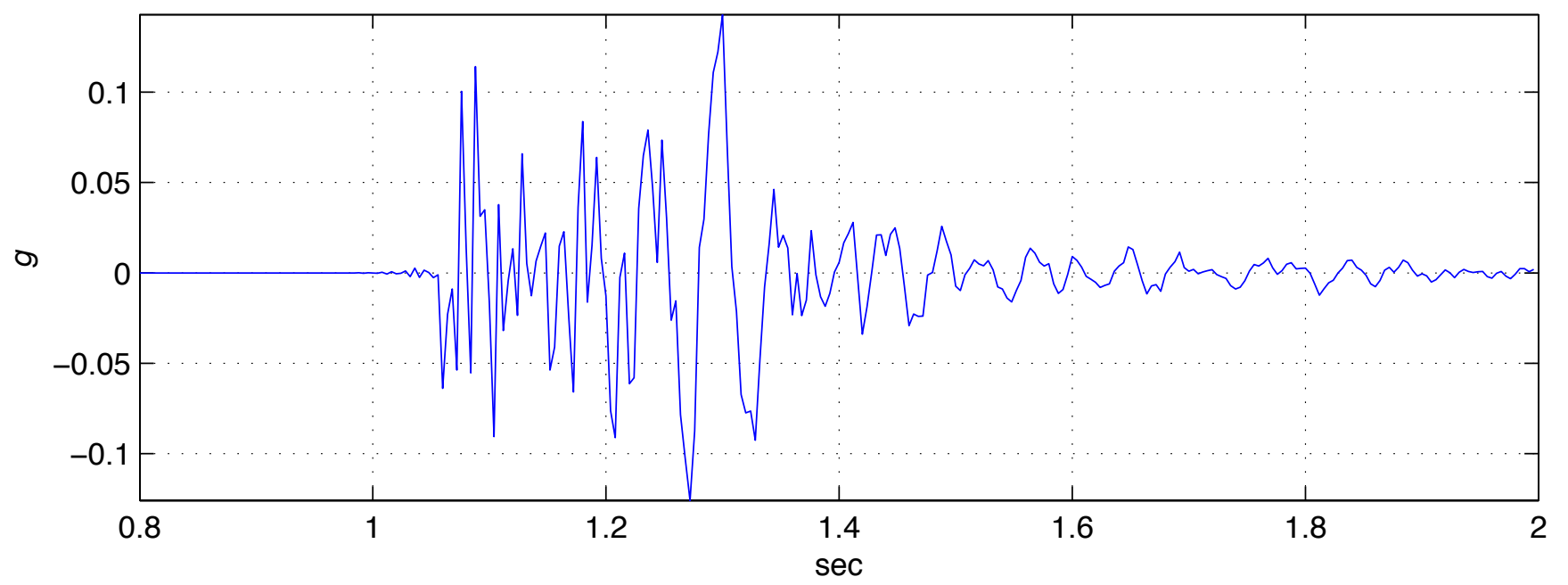

Shot name: sh1-sta103a.sgy Horizontal 2 Accel. max accel: $0.10252 \mathrm{~g}$ min accel: $-0.083046 \mathrm{~g}$

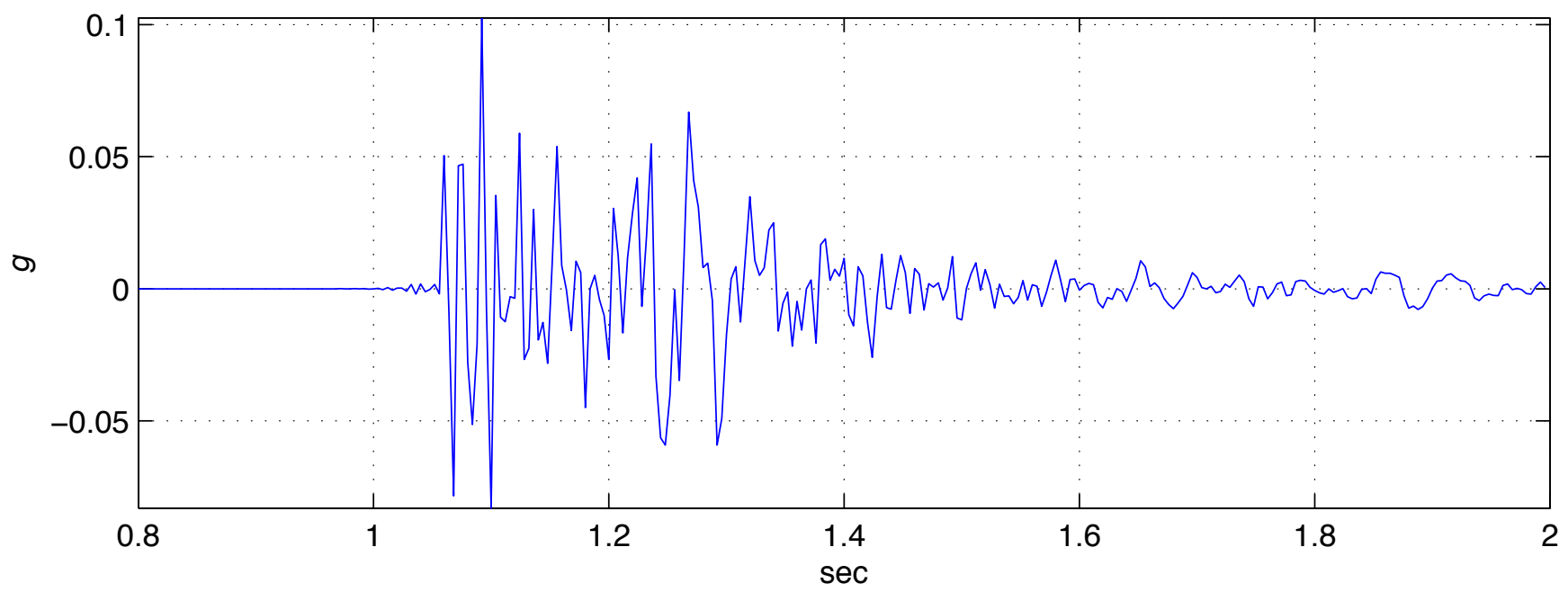




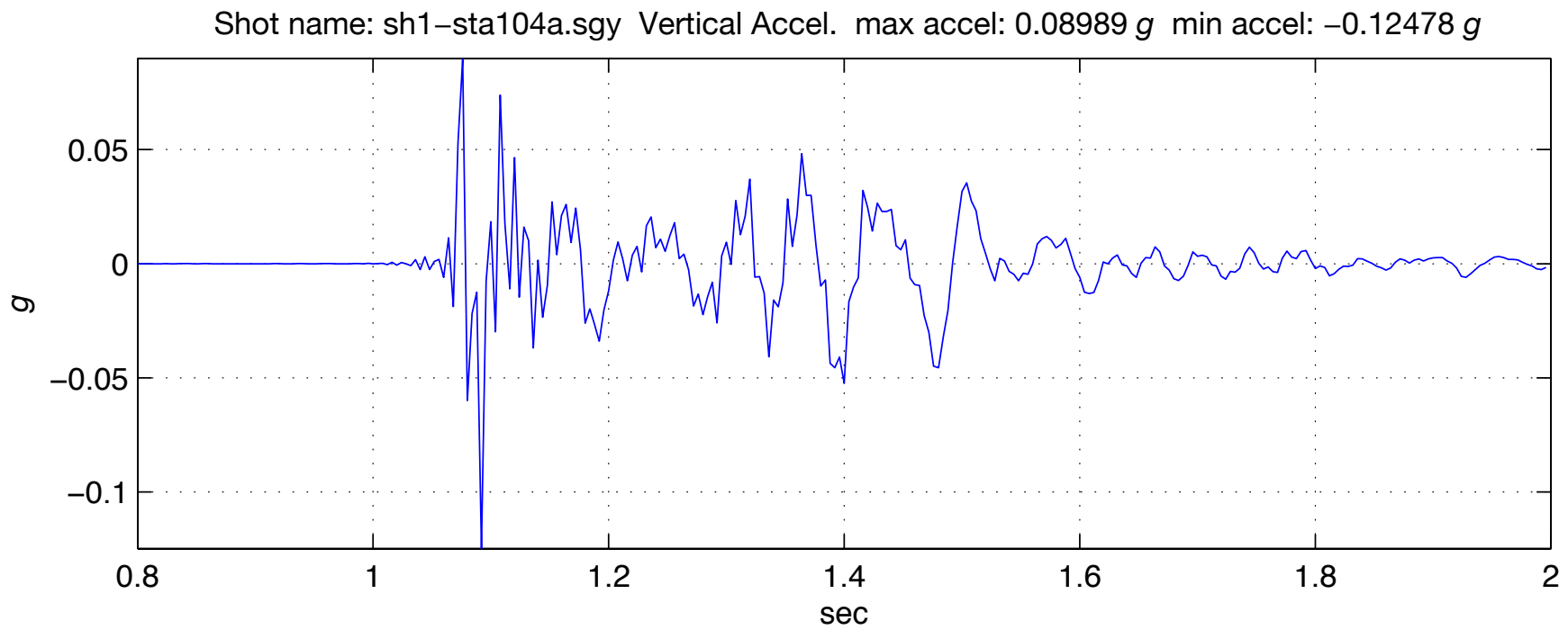

Shot name: sh1-sta104a.sgy Horizontal 1 Accel. max accel: $0.071409 \mathrm{~g}$ min accel: $-0.055794 \mathrm{~g}$

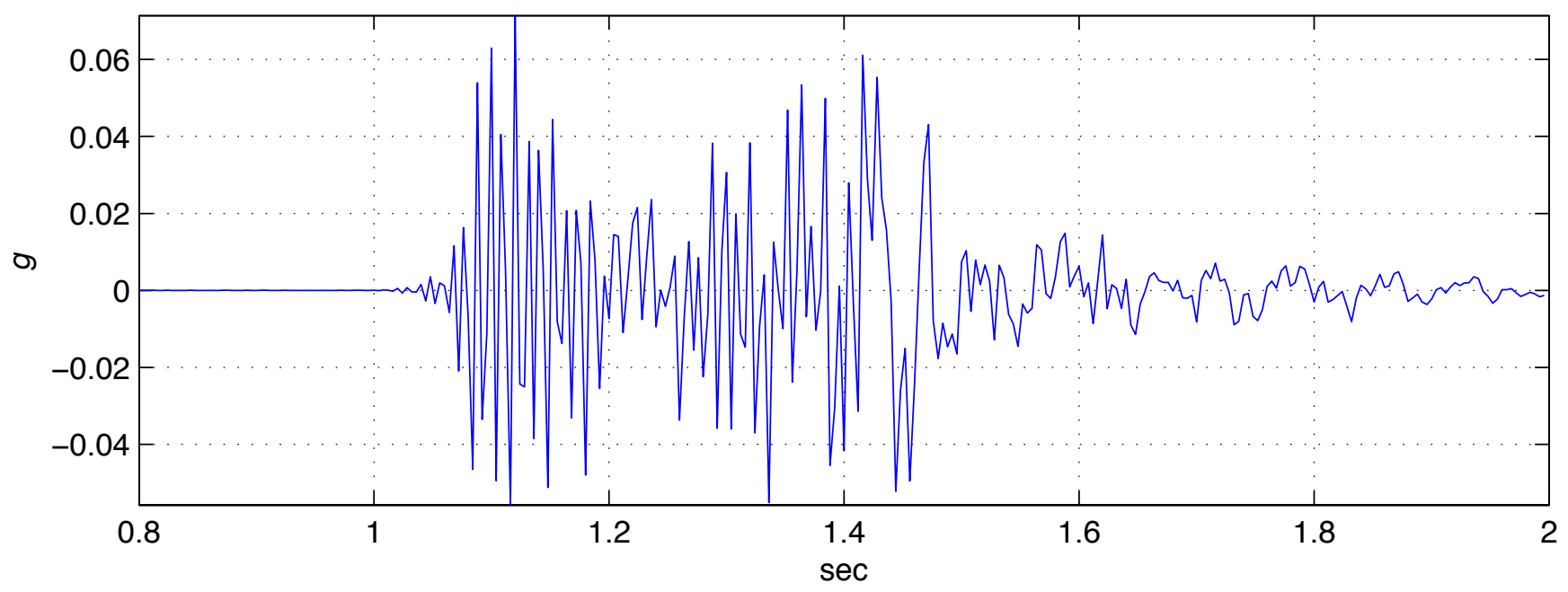

Shot name: sh1-sta104a.sgy Horizontal 2 Accel. max accel: $0.052224 \mathrm{~g}$ min accel: $-0.053431 \mathrm{~g}$

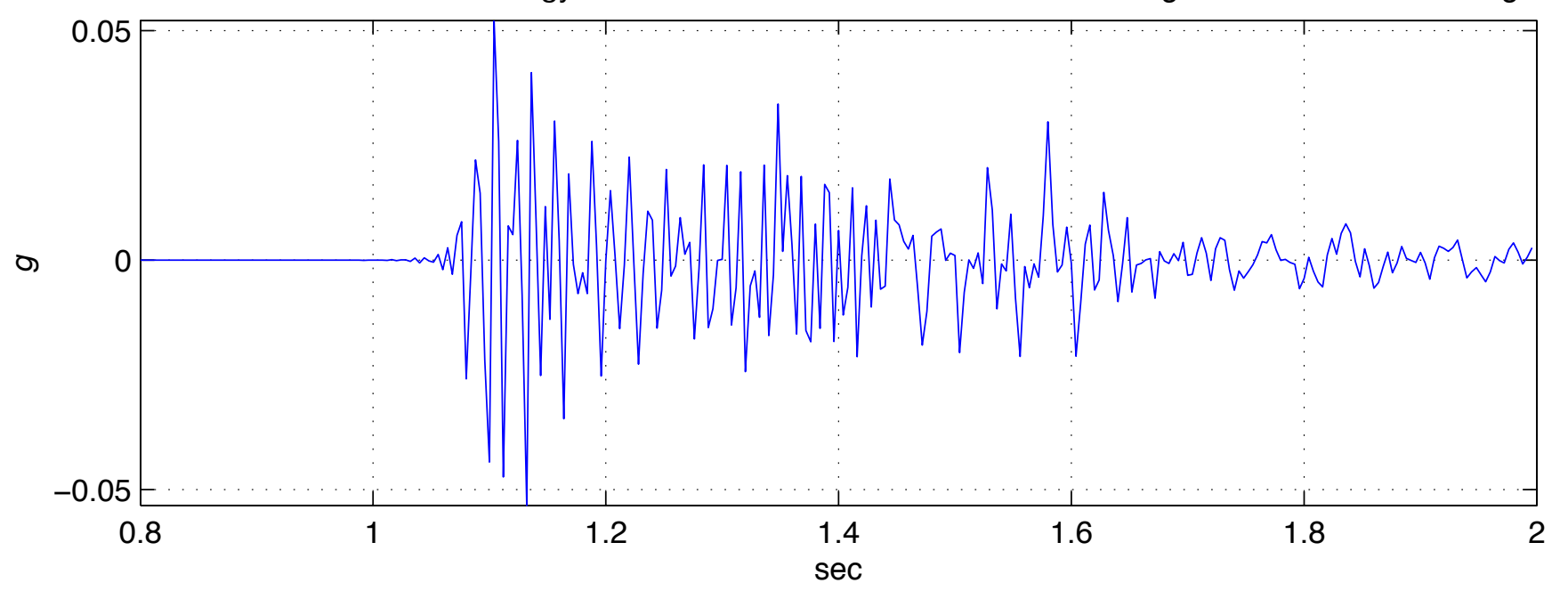




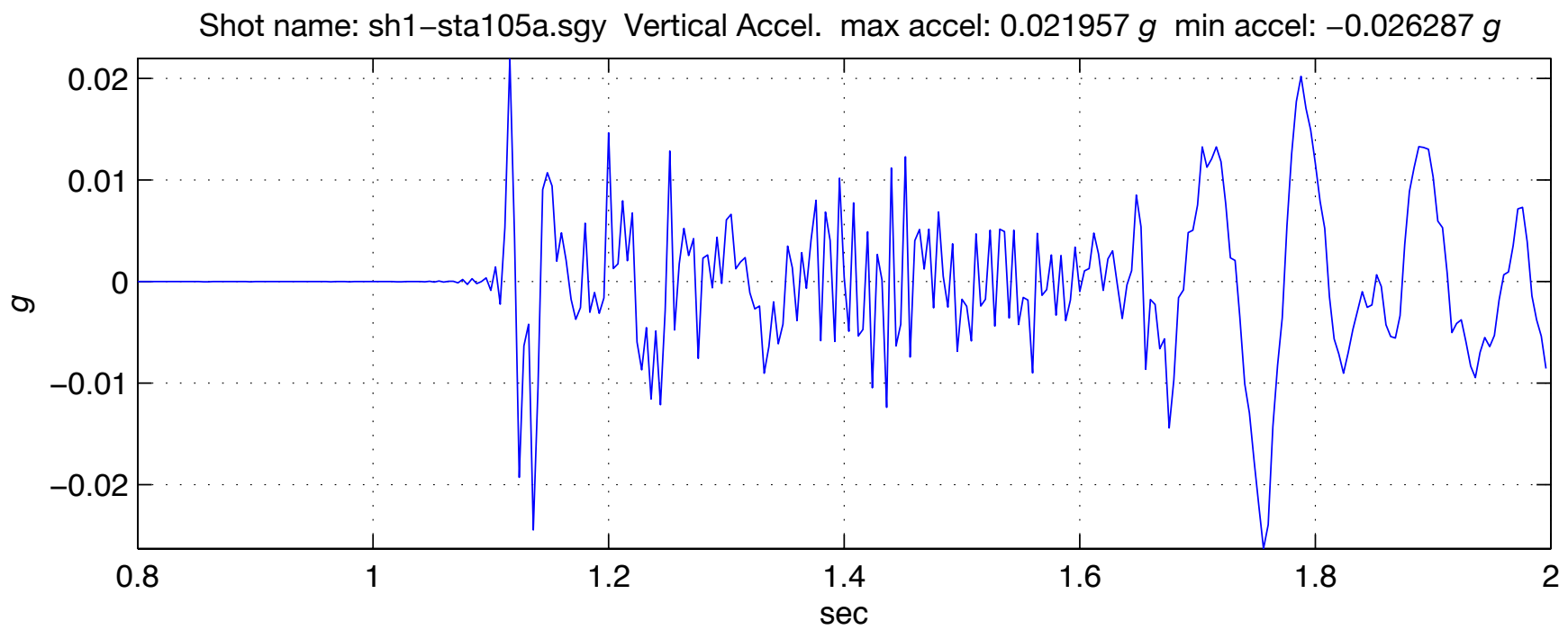

Shot name: sh1-sta105a.sgy Horizontal 1 Accel. max accel: $0.039189 \mathrm{~g}$ min accel: $-0.035993 \mathrm{~g}$

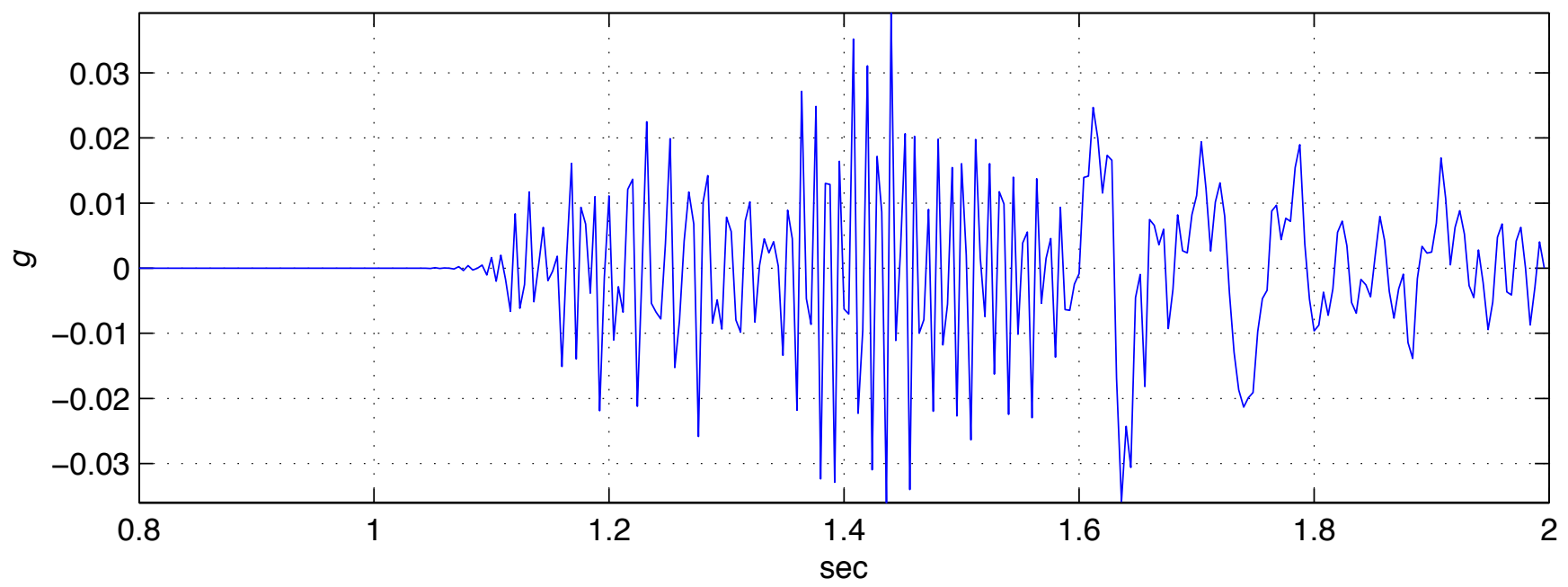

Shot name: sh1-sta105a.sgy Horizontal 2 Accel. max accel: $0.023922 g$ min accel: $-0.028609 g$

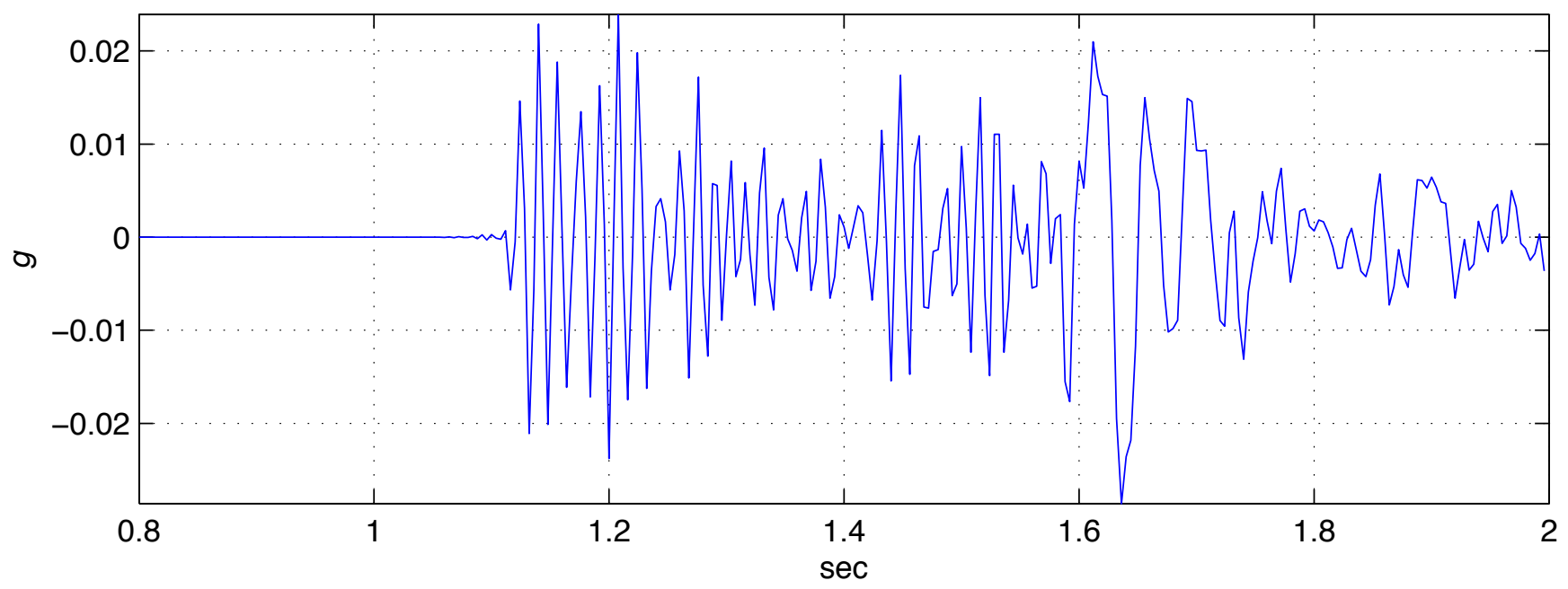


Shot name: sh1-sta106a.sgy Vertical Accel. max accel: $0.023164 \mathrm{~g}$ min accel: $-0.051411 \mathrm{~g}$

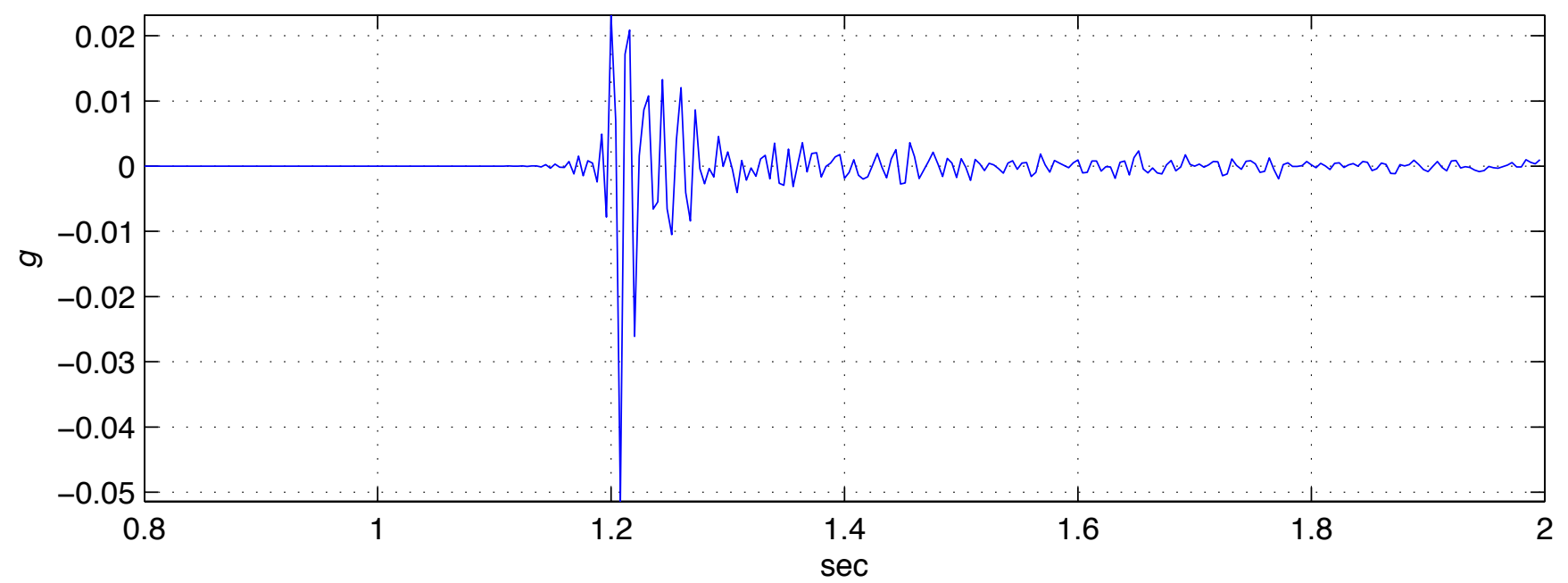

Shot name: sh1-sta106a.sgy Horizontal 1 Accel. max accel: $0.019551 \mathrm{~g}$ min accel: $-0.018564 \mathrm{~g}$

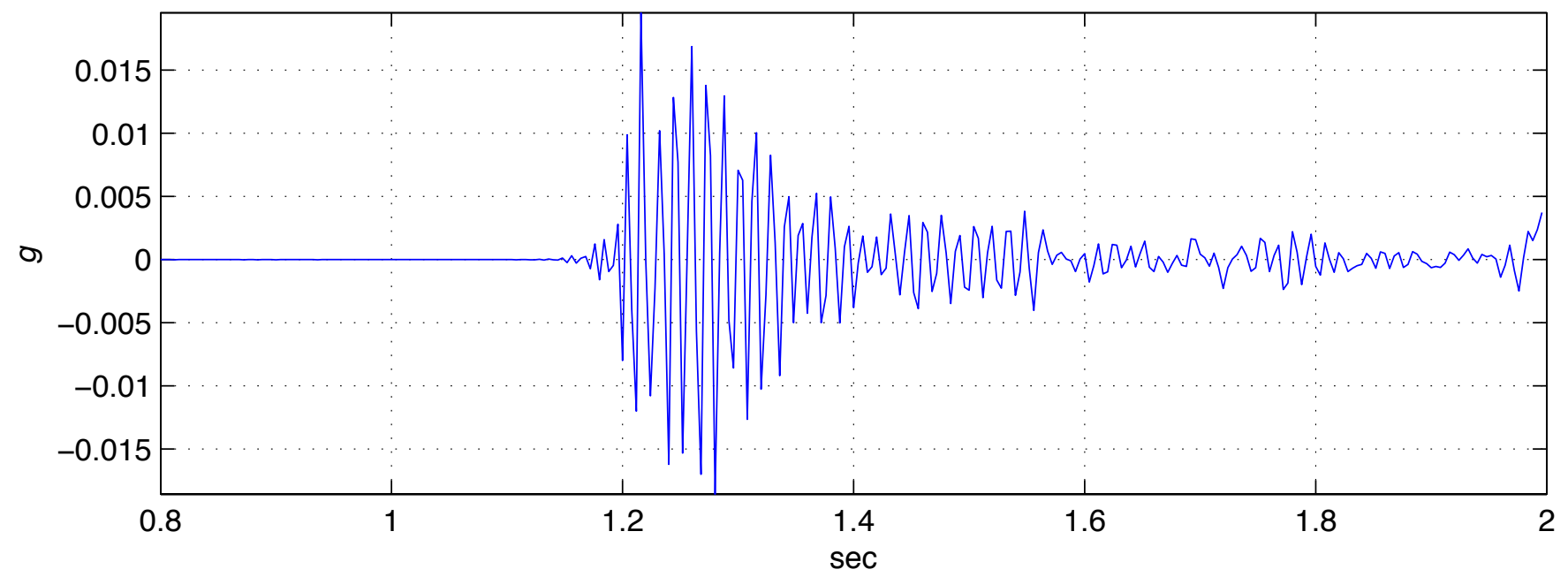

Shot name: sh1-sta106a.sgy Horizontal 2 Accel. max accel: $0.012602 \mathrm{~g}$ min accel: $-0.013683 \mathrm{~g}$

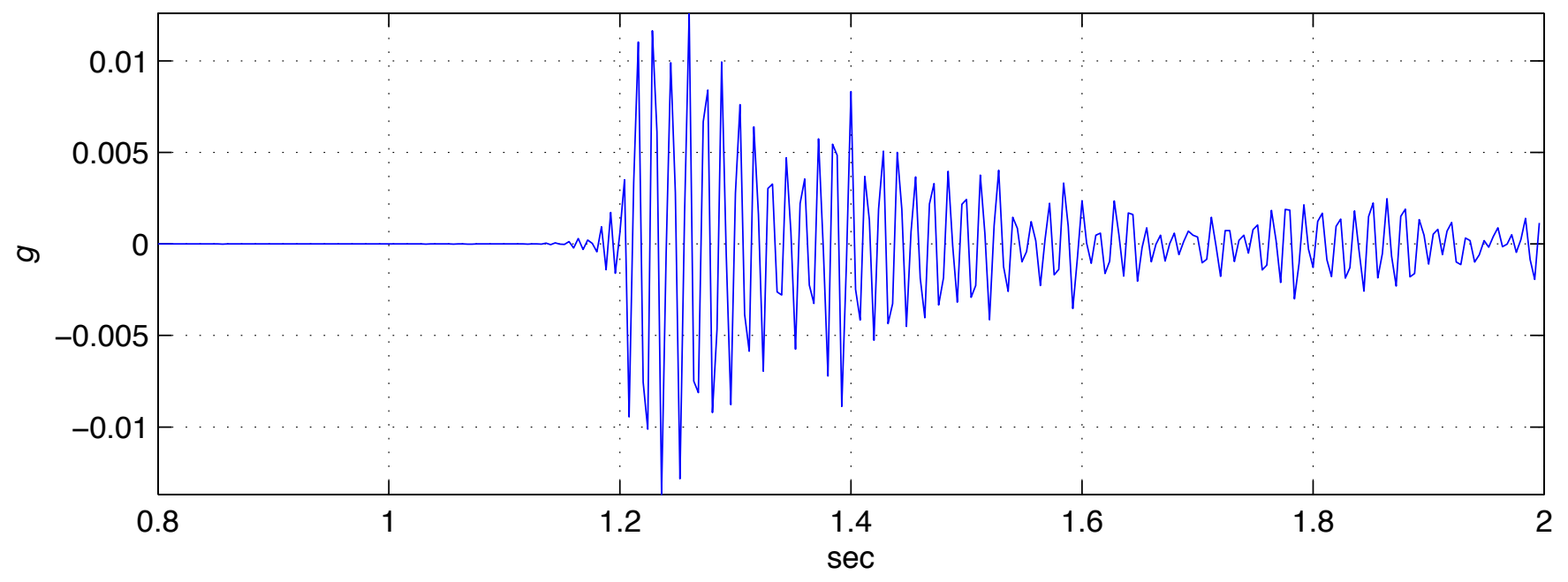




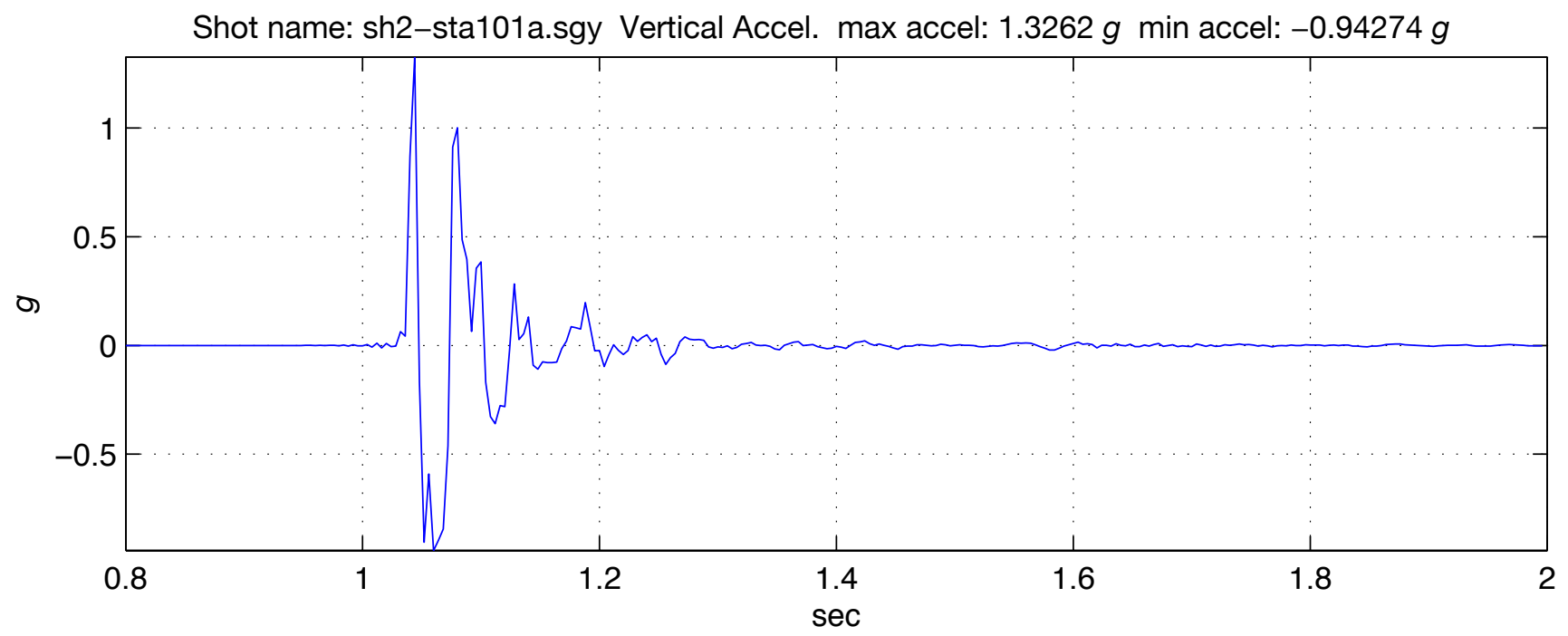

Shot name: sh2-sta101a.sgy Horizontal 1 Accel. max accel: $0.61736 g$ min accel: $-0.80075 g$

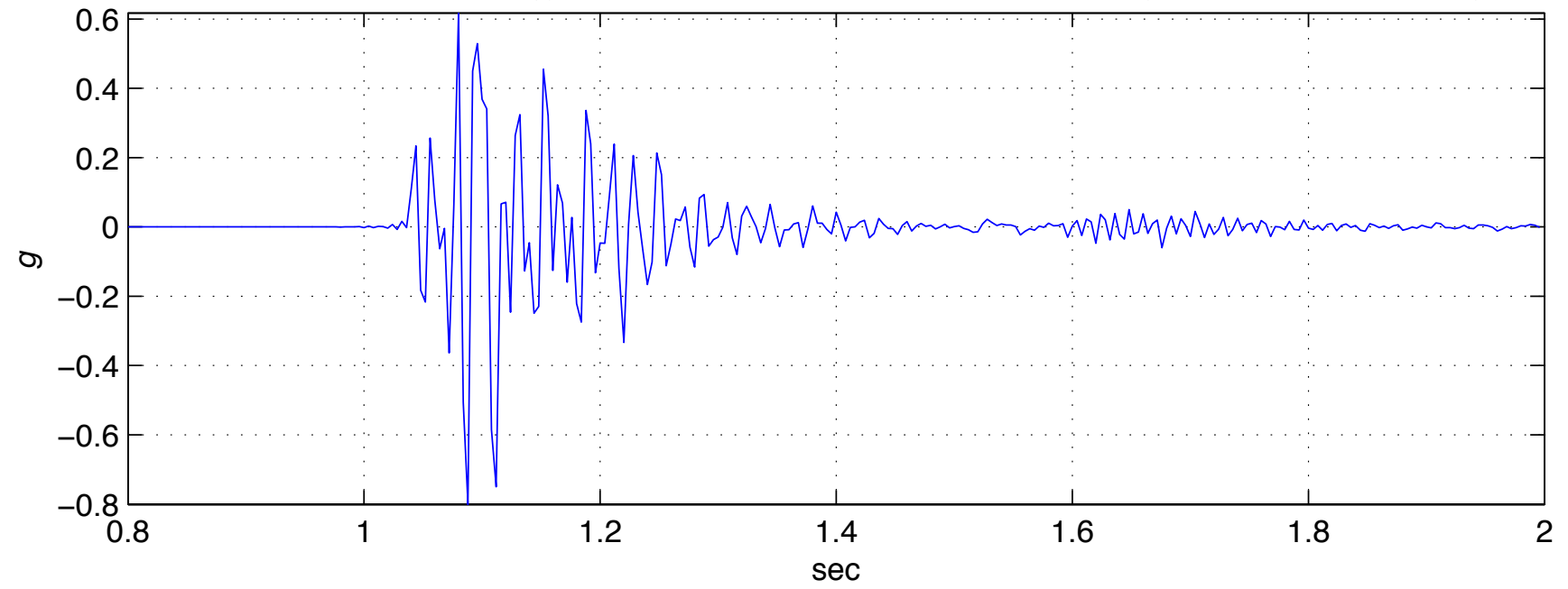

Shot name: sh2-sta101a.sgy Horizontal 2 Accel. max accel: $0.81696 \mathrm{~g}$ min accel: $-1.1466 \mathrm{~g}$

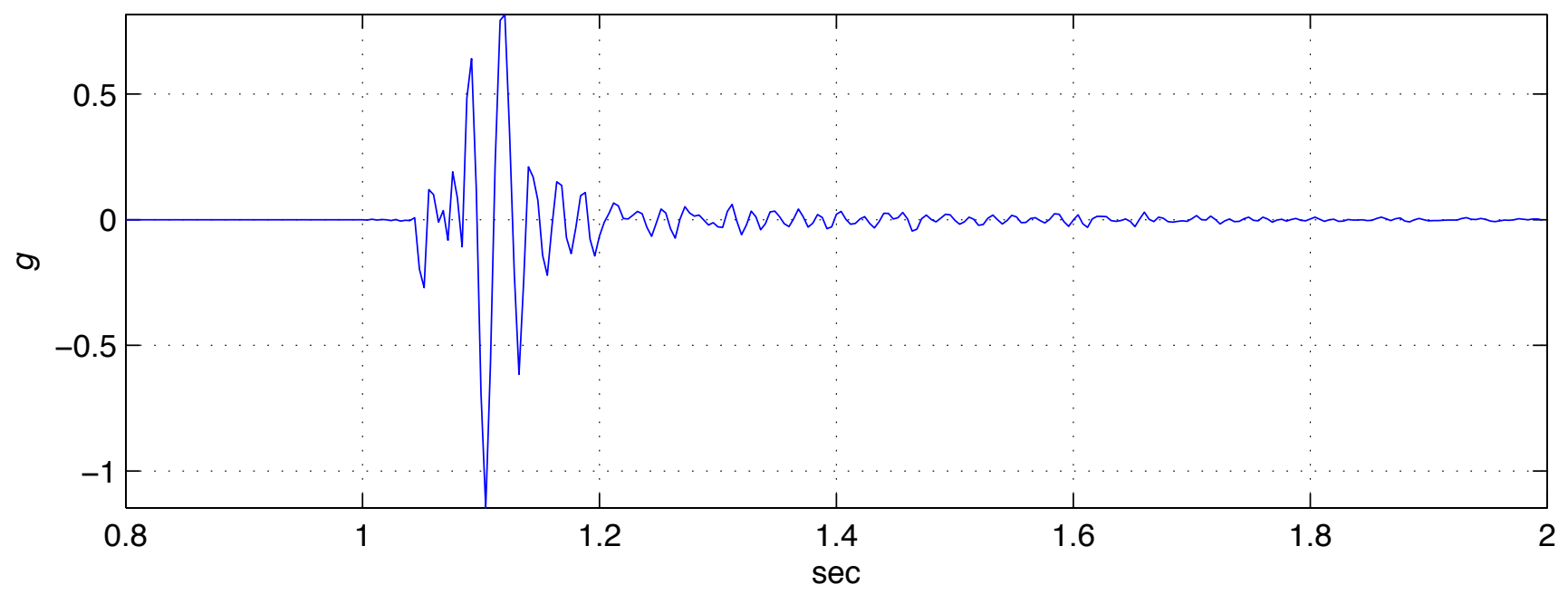


Shot name: sh2-sta102a.sgy Vertical Accel. max accel: $1.78 \mathrm{~g}$ min accel: $-1.0599 \mathrm{~g}$

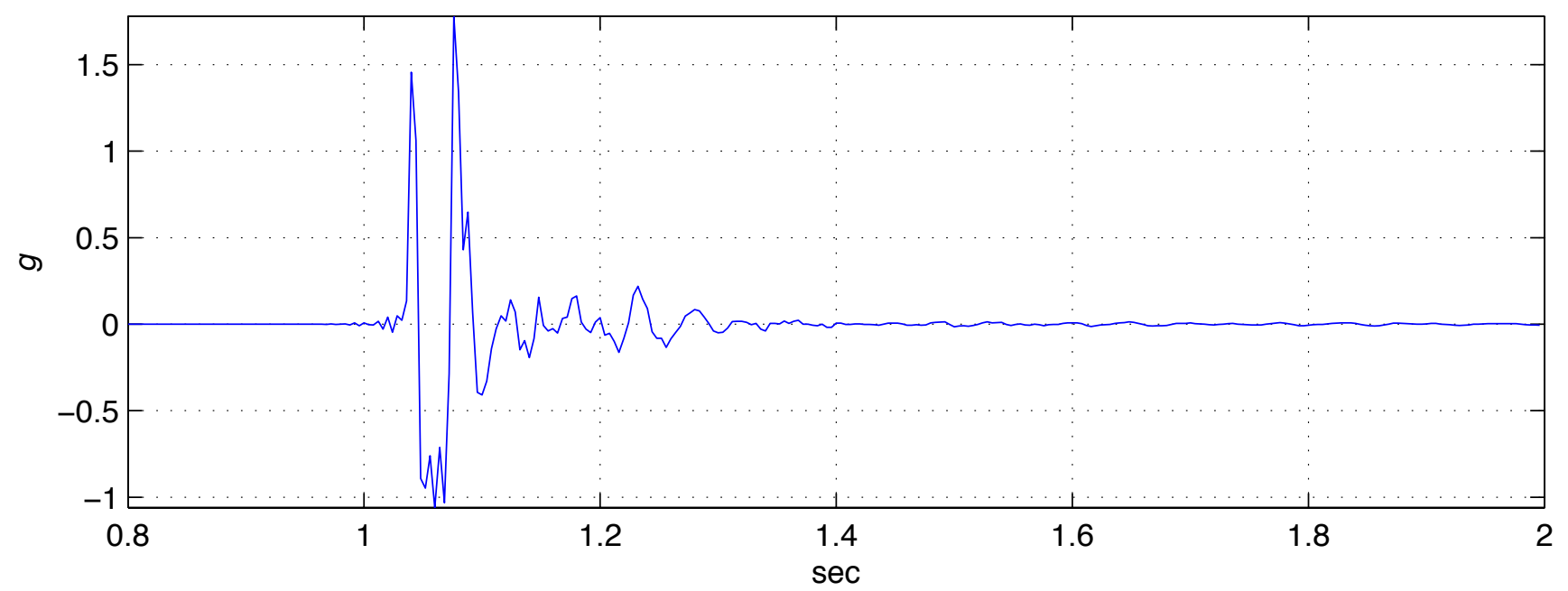

Shot name: sh2-sta102a.sgy Horizontal 1 Accel. max accel: $0.40143 g$ min accel: $-0.44623 g$

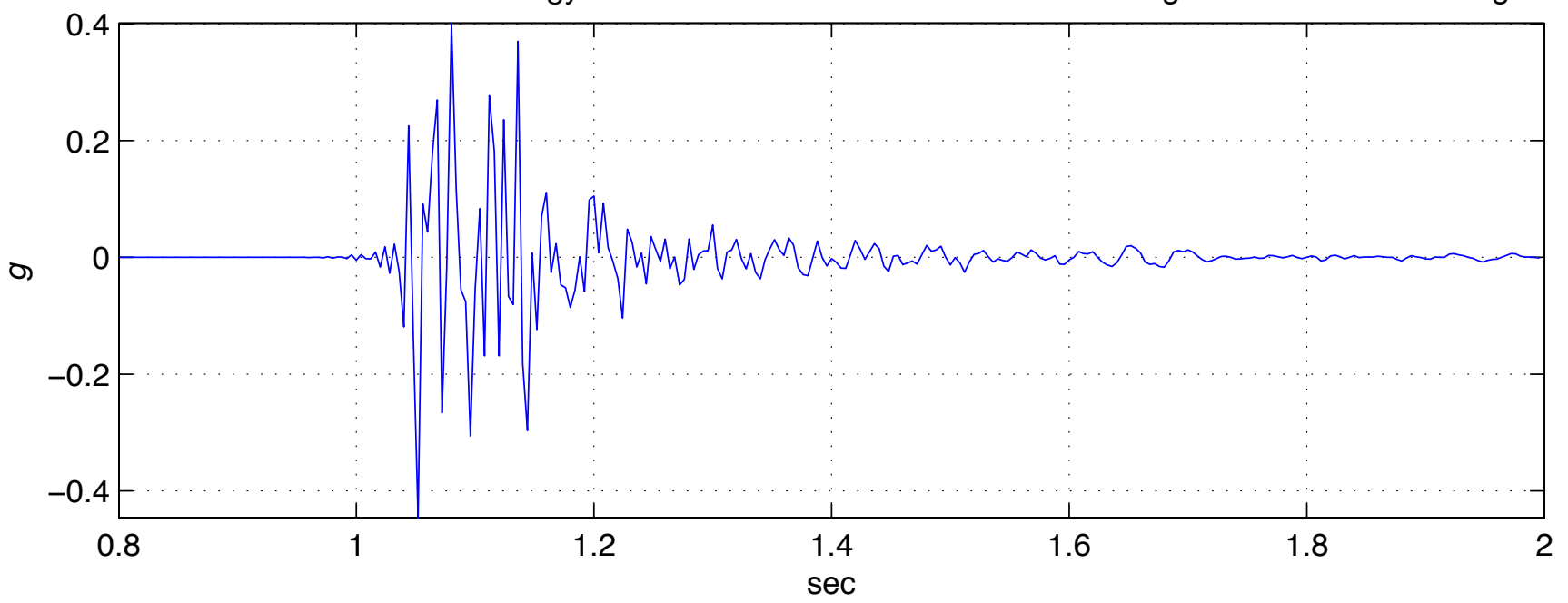

Shot name: sh2-sta102a.sgy Horizontal 2 Accel. max accel: $0.48984 \mathrm{~g}$ min accel: $-0.41308 \mathrm{~g}$

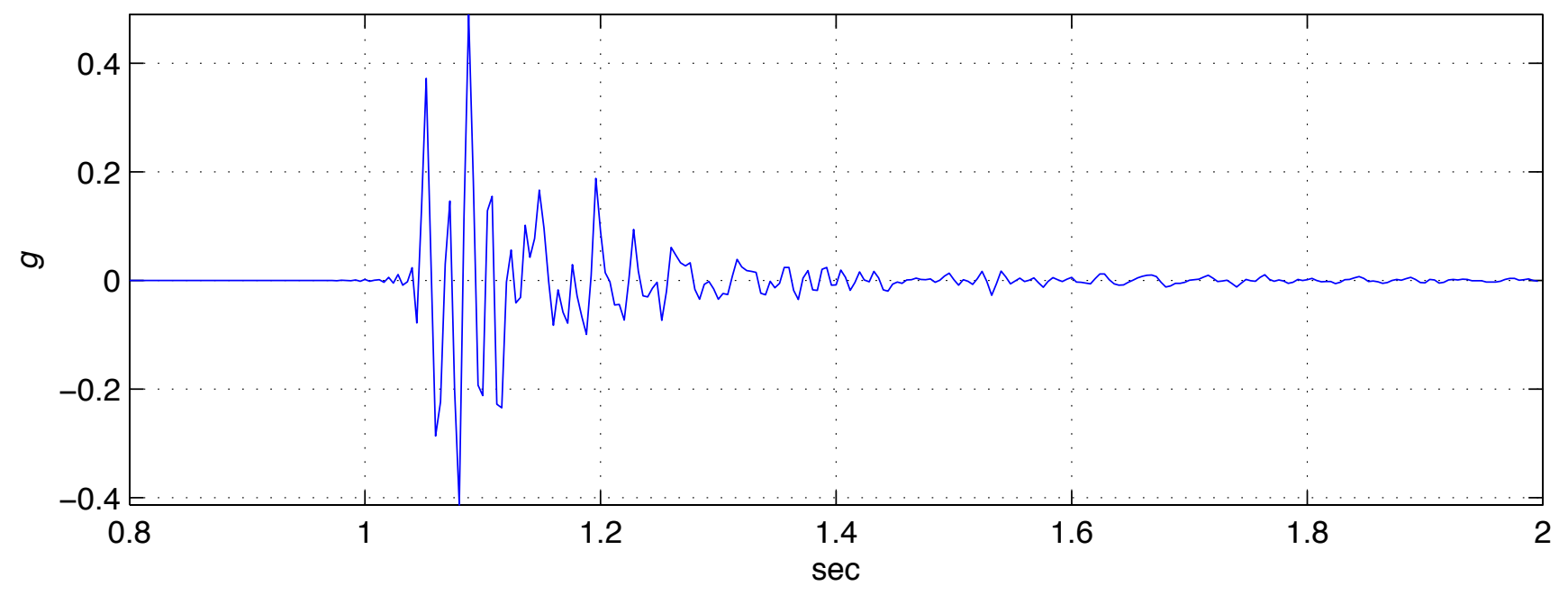




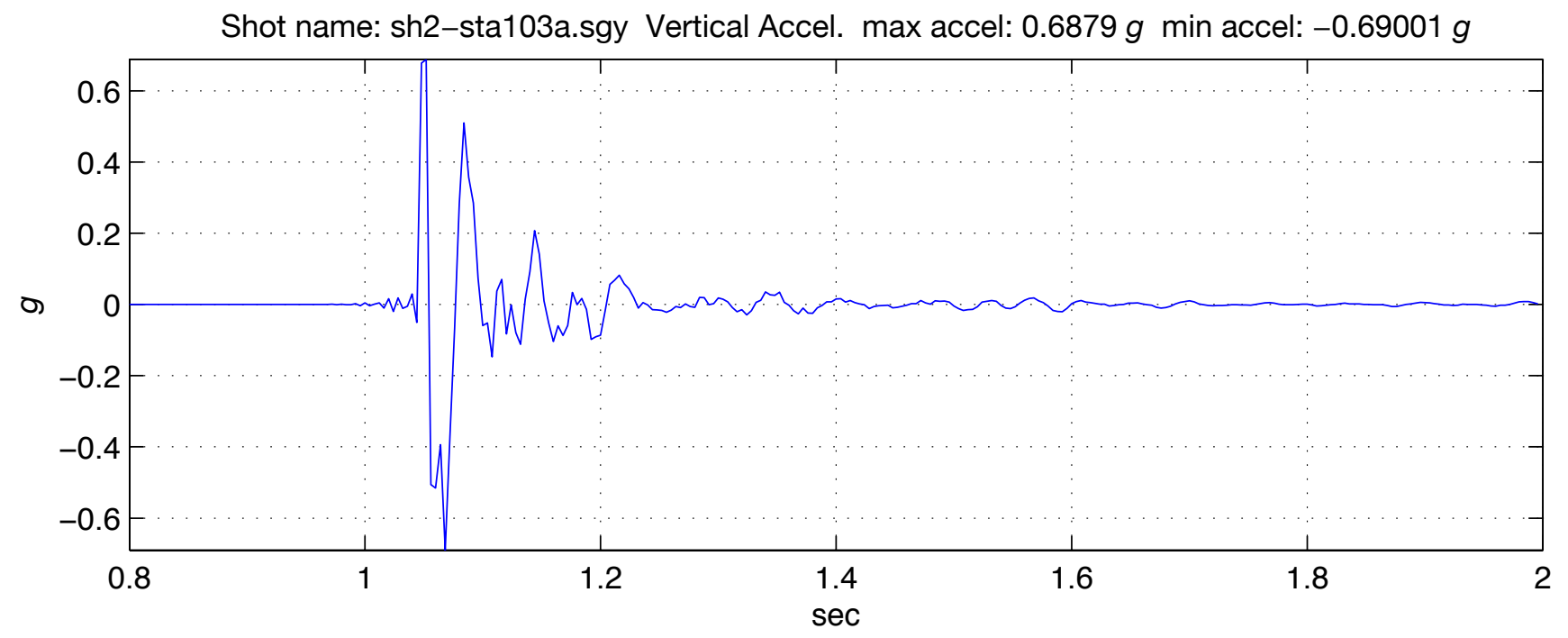

Shot name: sh2-sta103a.sgy Horizontal 1 Accel. max accel: $0.26058 \mathrm{~g}$ min accel: $-0.22623 \mathrm{~g}$

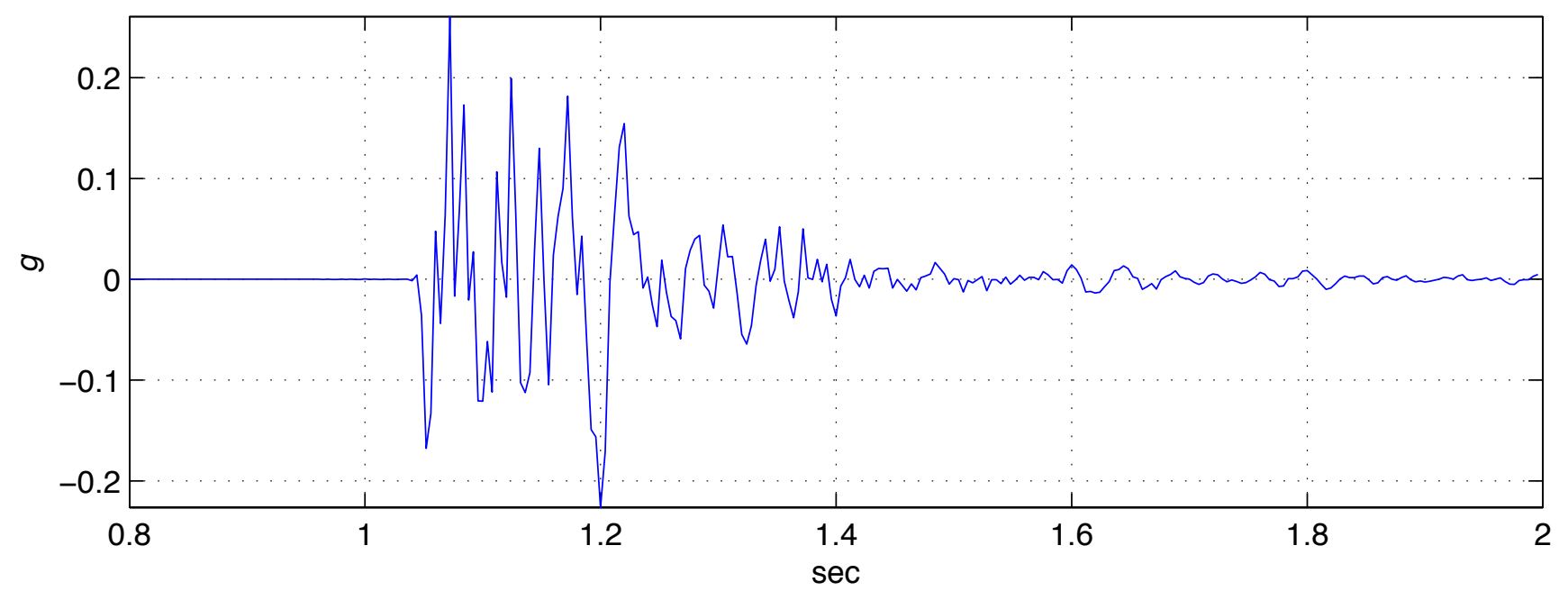

Shot name: sh2-sta103a.sgy Horizontal 2 Accel. max accel: $0.21667 \mathrm{~g}$ min accel: $-0.22969 \mathrm{~g}$

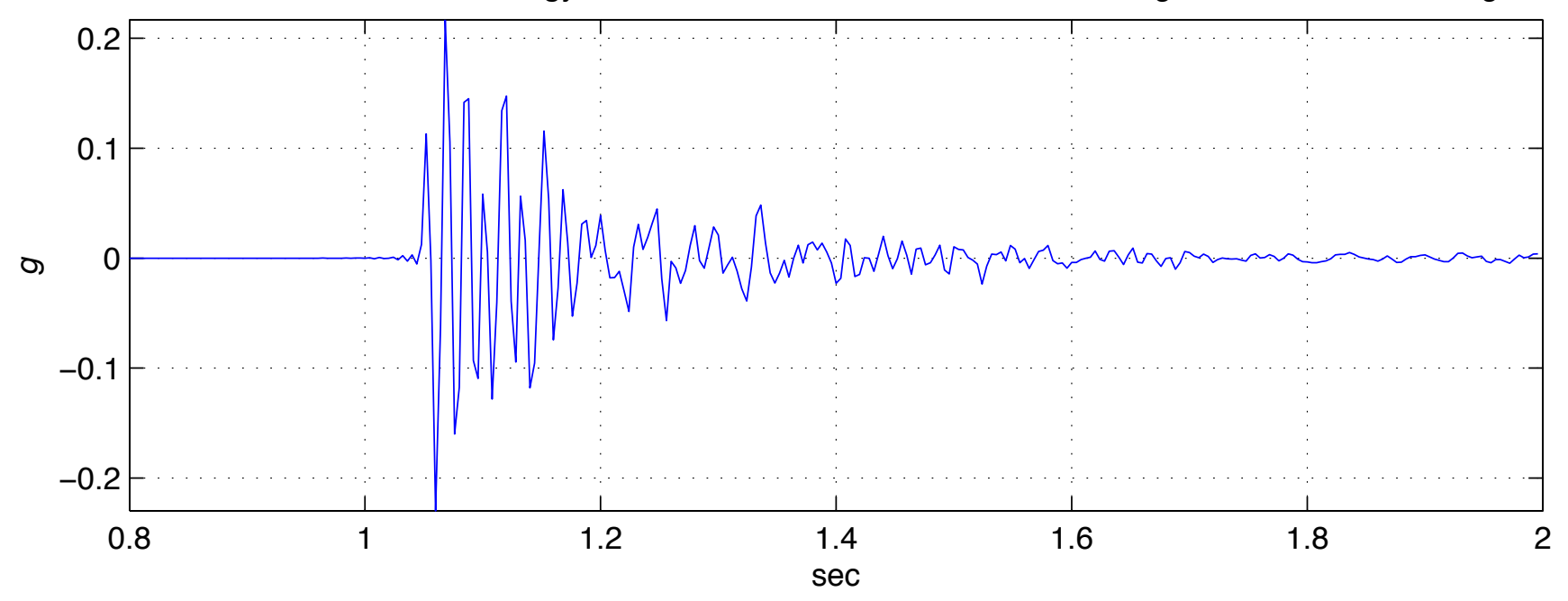




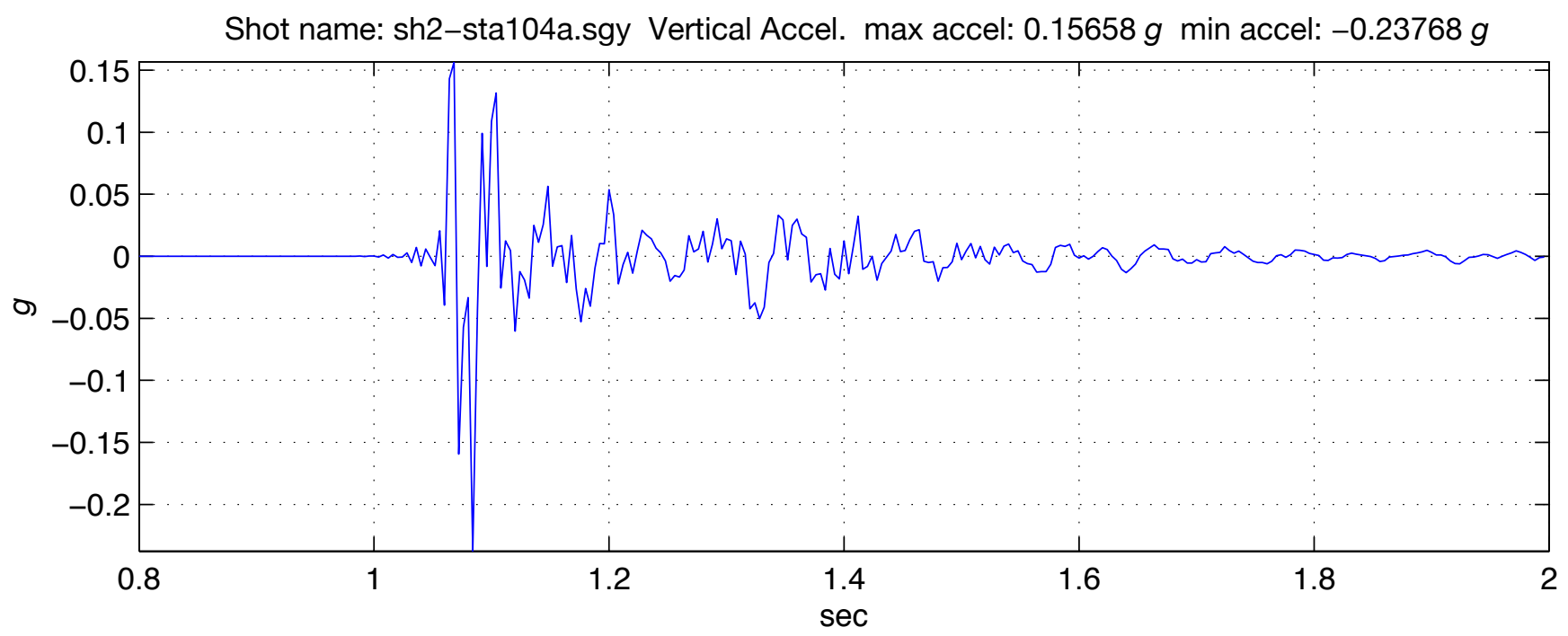

Shot name: sh2-sta104a.sgy Horizontal 1 Accel. max accel: $0.11088 \mathrm{~g}$ min accel: $-0.094874 \mathrm{~g}$

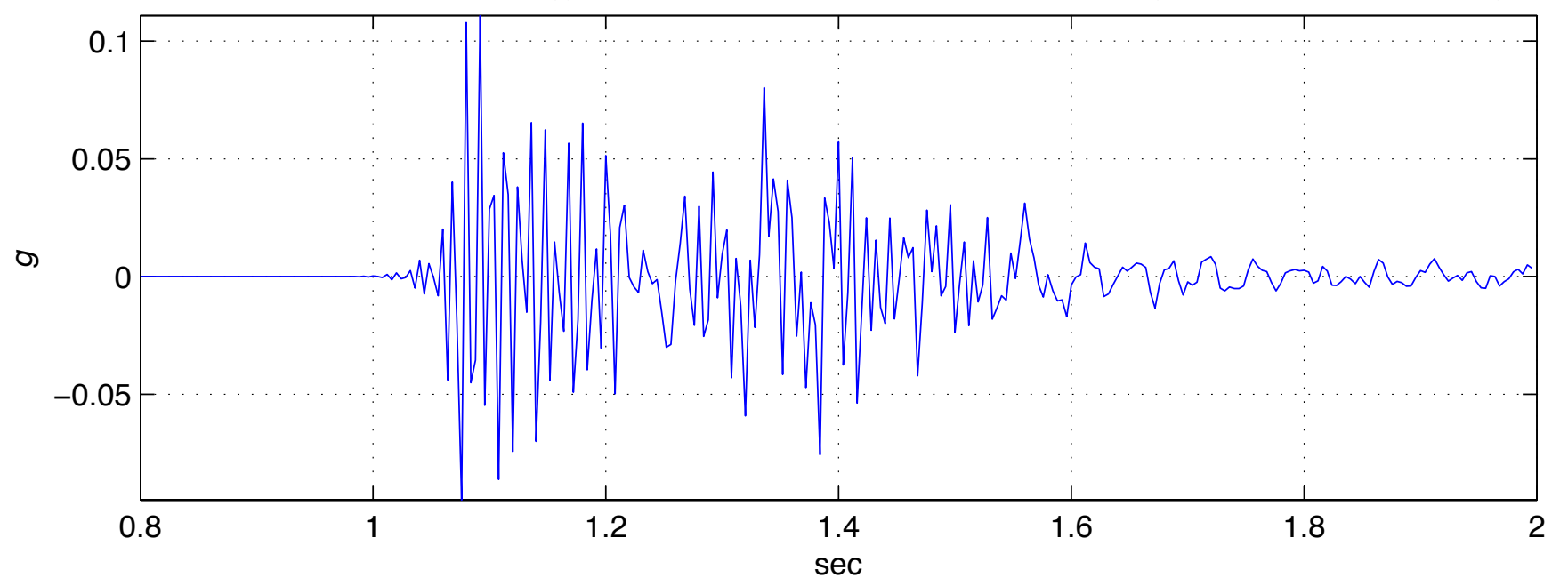

Shot name: sh2-sta104a.sgy Horizontal 2 Accel. max accel: $0.086509 \mathrm{~g}$ min accel: $-0.075006 \mathrm{~g}$

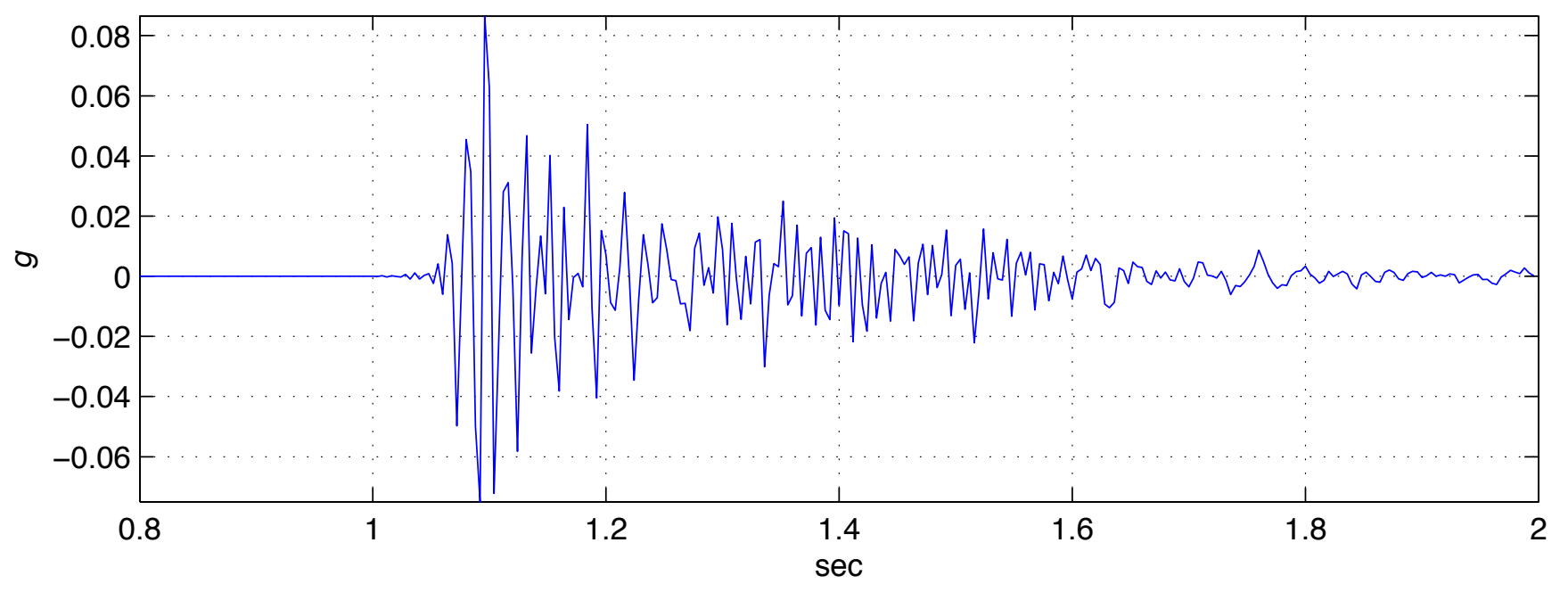




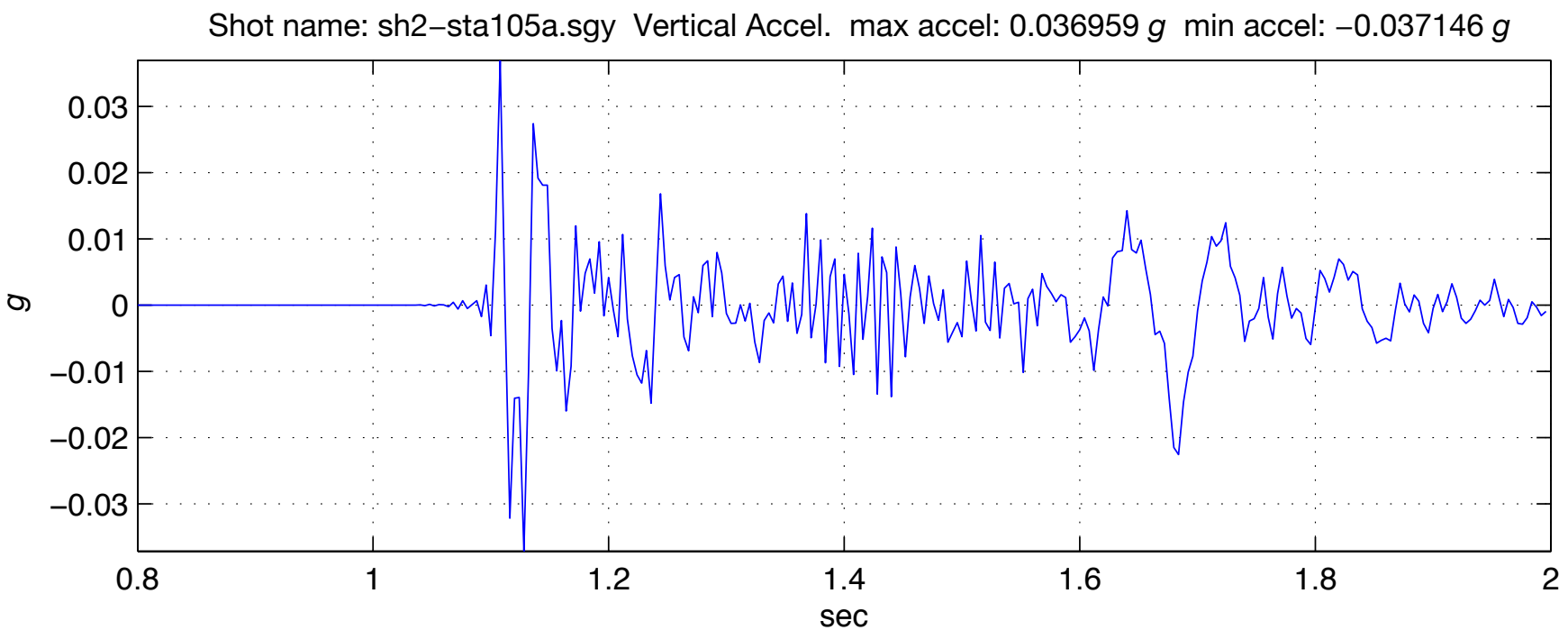

Shot name: sh2-sta105a.sgy Horizontal 1 Accel. max accel: $0.043144 \mathrm{~g}$ min accel: $-0.052607 \mathrm{~g}$

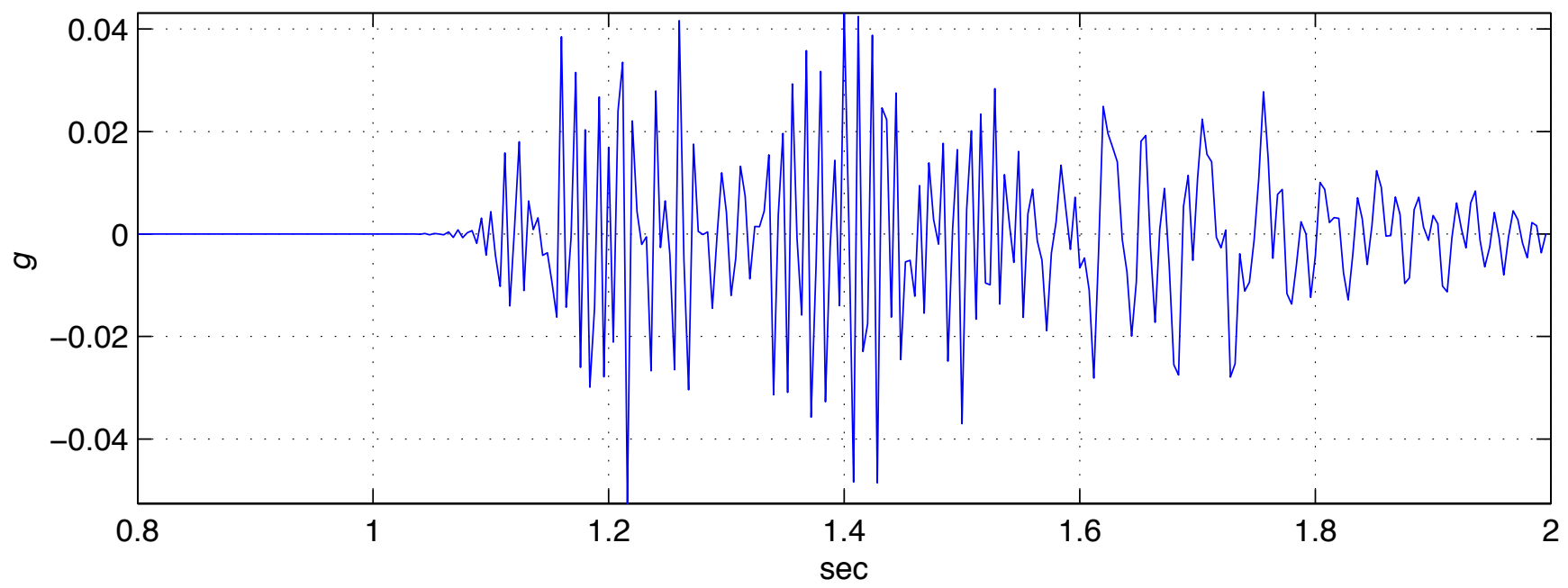

Shot name: sh2-sta105a.sgy Horizontal 2 Accel. max accel: $0.040626 \mathrm{~g}$ min accel: $-0.034271 \mathrm{~g}$

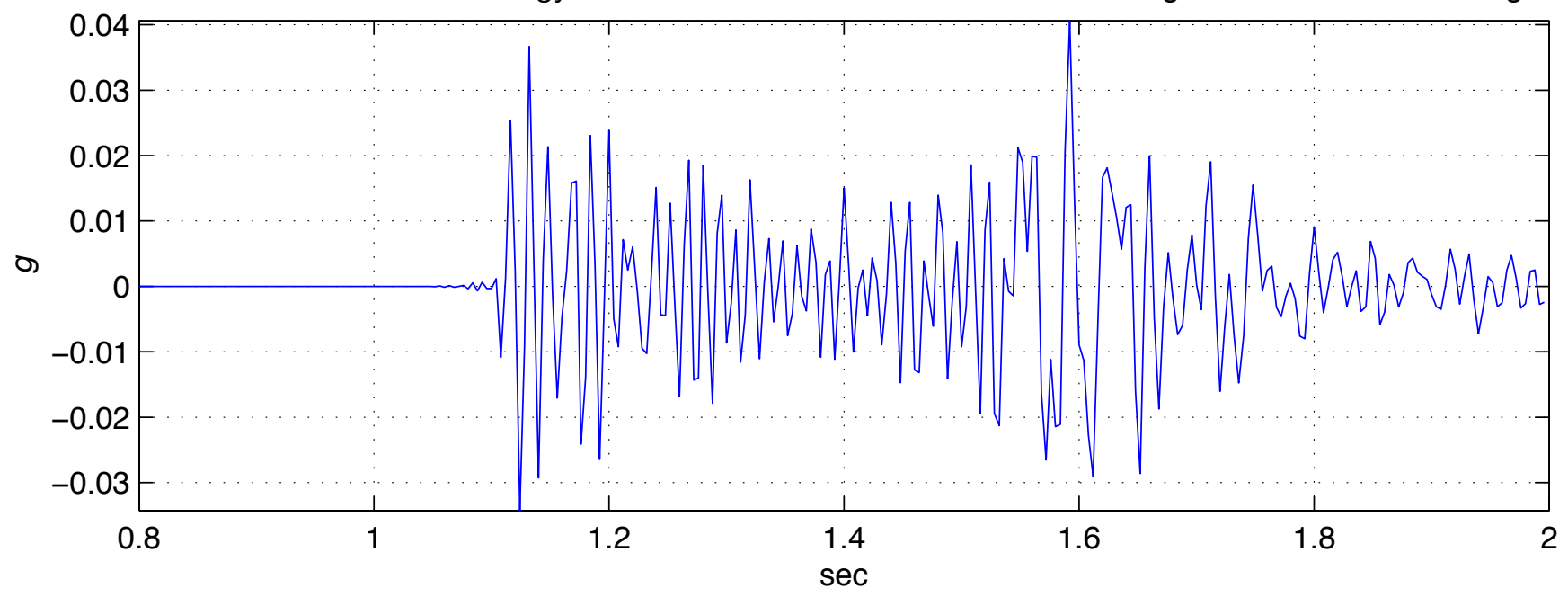




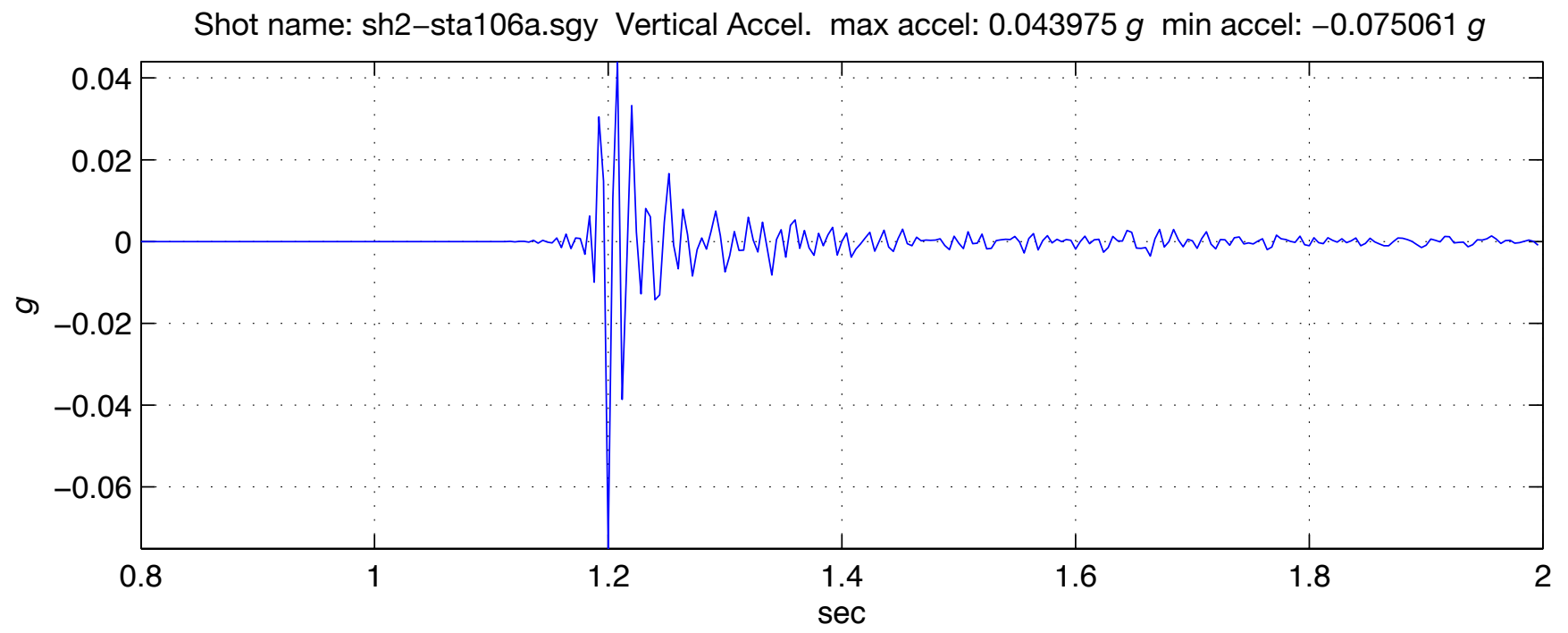

Shot name: sh2-sta106a.sgy Horizontal 1 Accel. max accel: $0.030439 \mathrm{~g}$ min accel: $-0.028801 \mathrm{~g}$

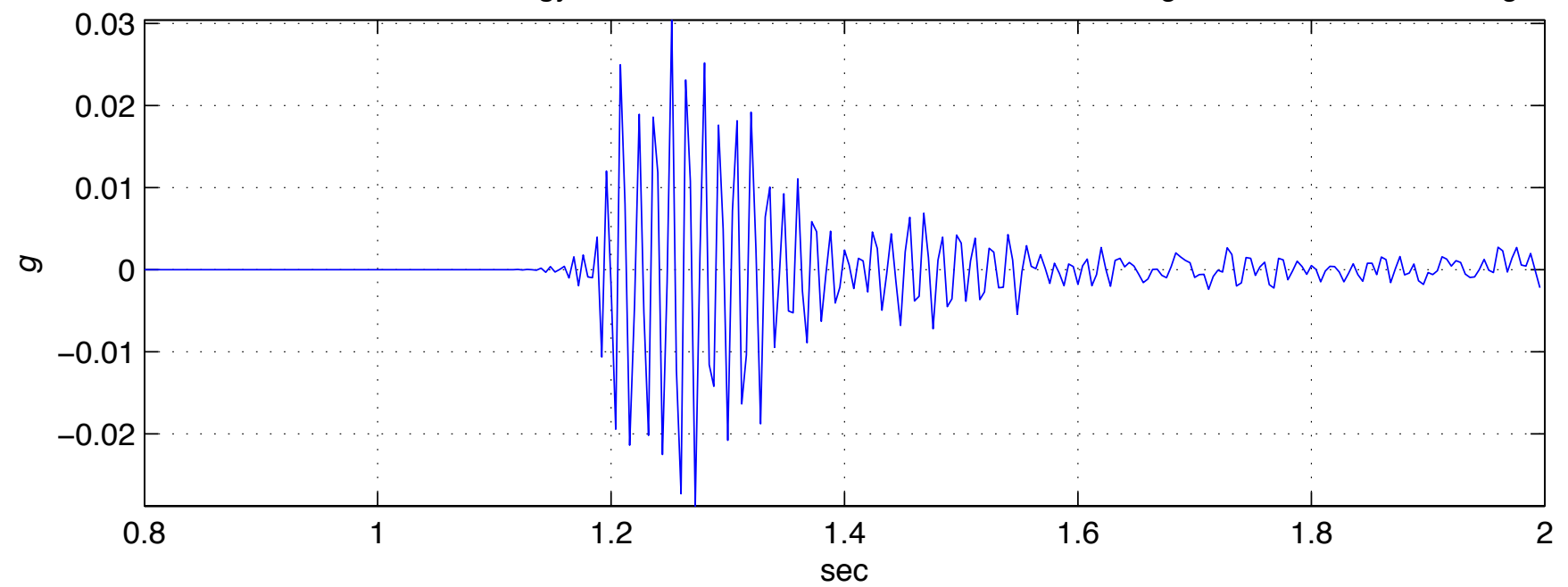

Shot name: sh2-sta106a.sgy Horizontal 2 Accel. max accel: $0.017342 \mathrm{~g}$ min accel: $-0.021282 \mathrm{~g}$

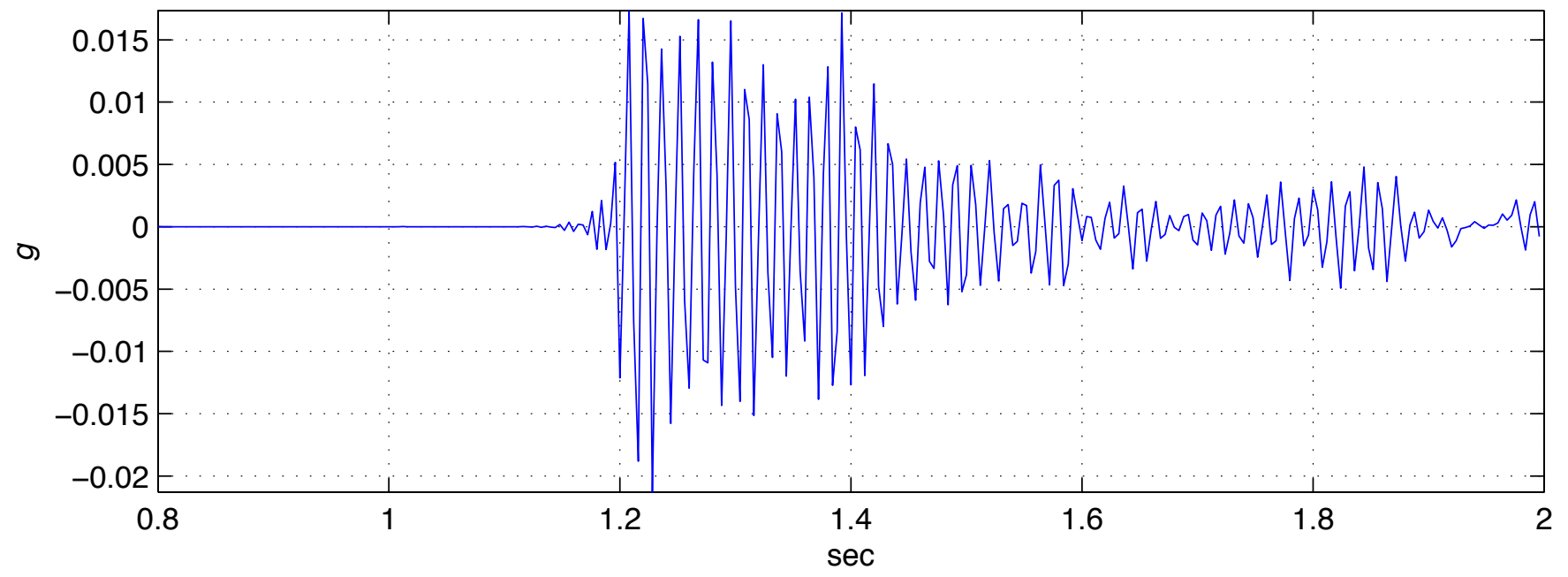




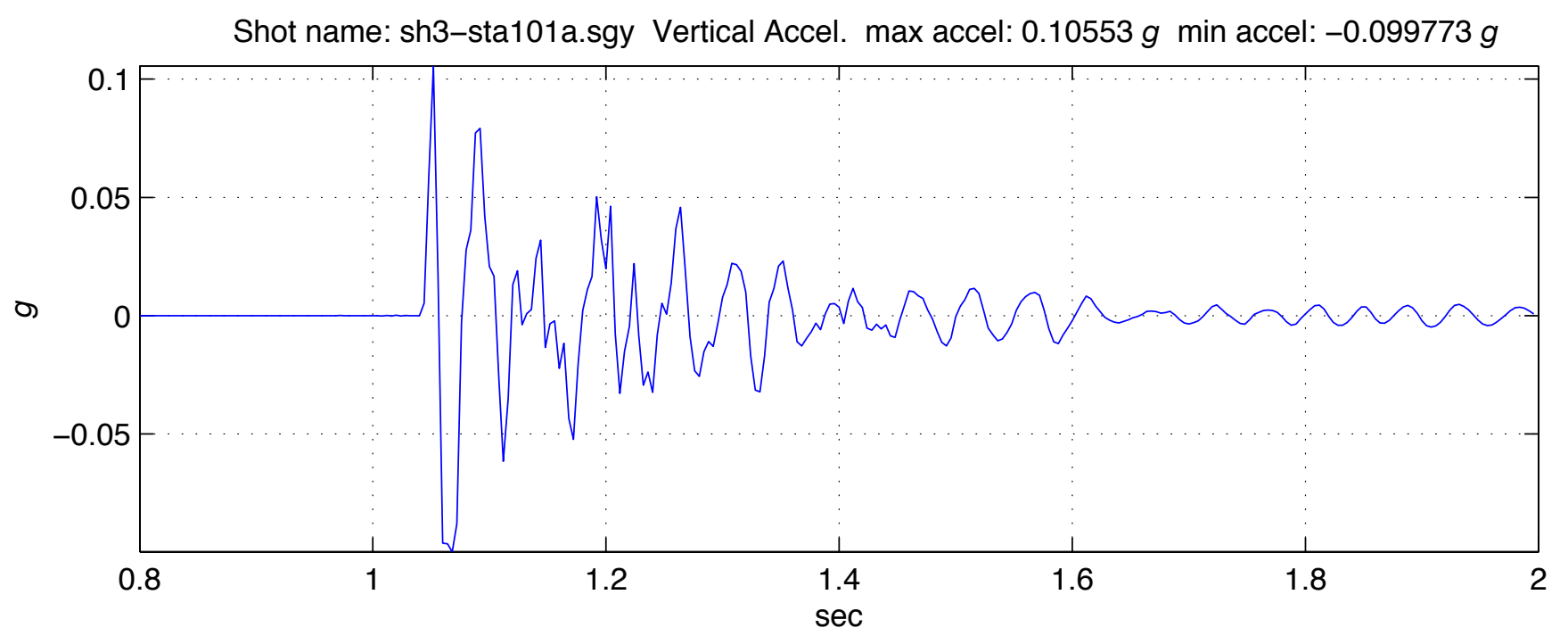

Shot name: sh3-sta101a.sgy Horizontal 1 Accel. max accel: $0.17388 \mathrm{~g} \min$ accel: $-0.16363 \mathrm{~g}$

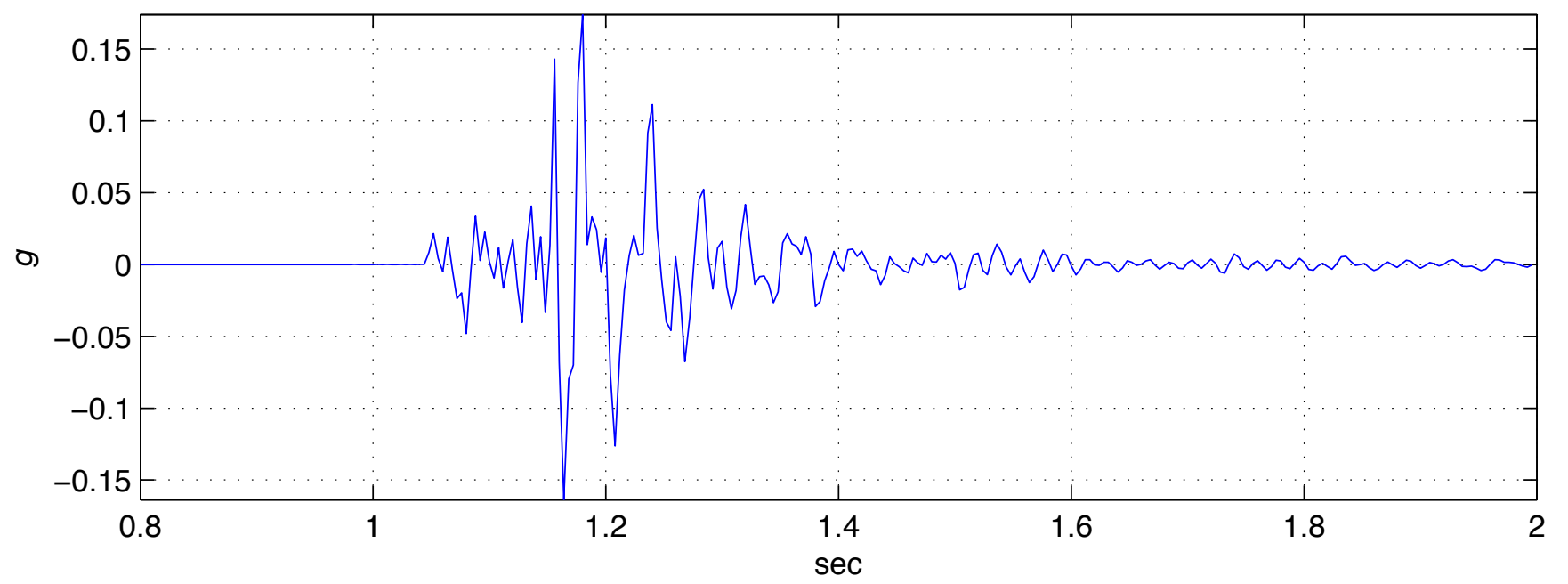

Shot name: sh3-sta101a.sgy Horizontal 2 Accel. max accel: $0.18878 \mathrm{~g}$ min accel: $-0.2646 \mathrm{~g}$

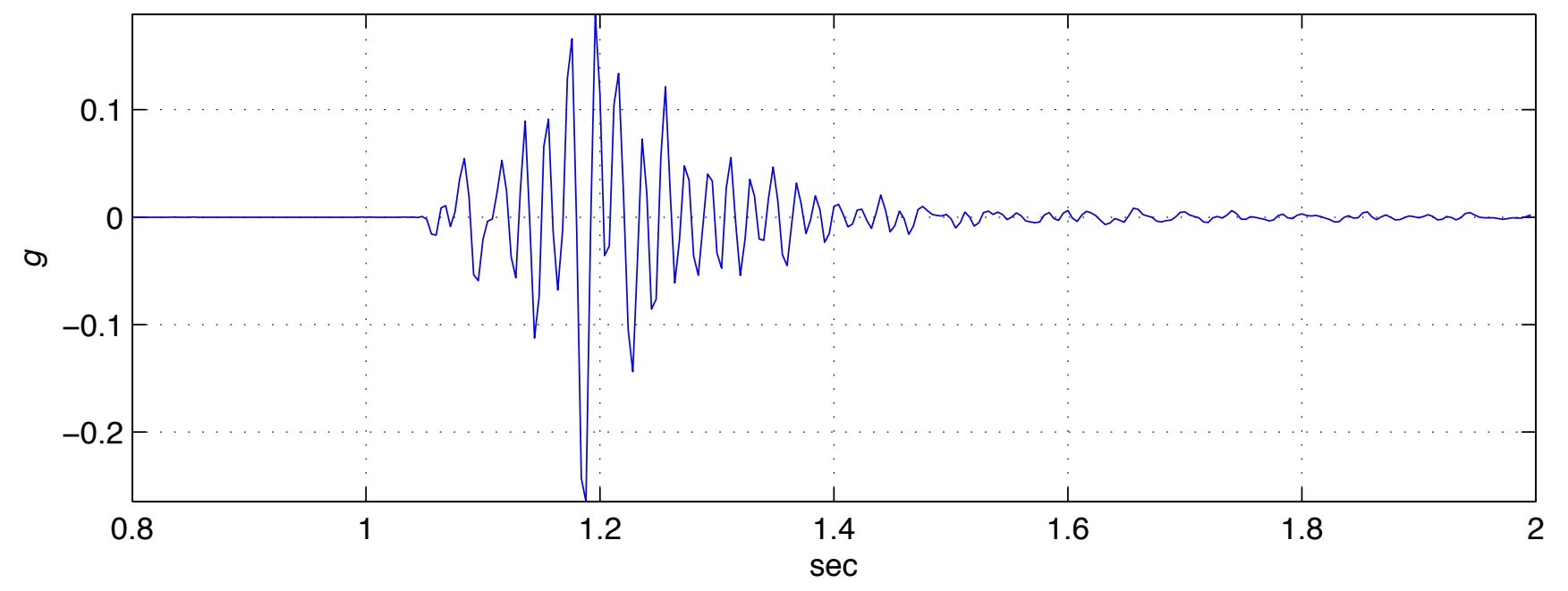




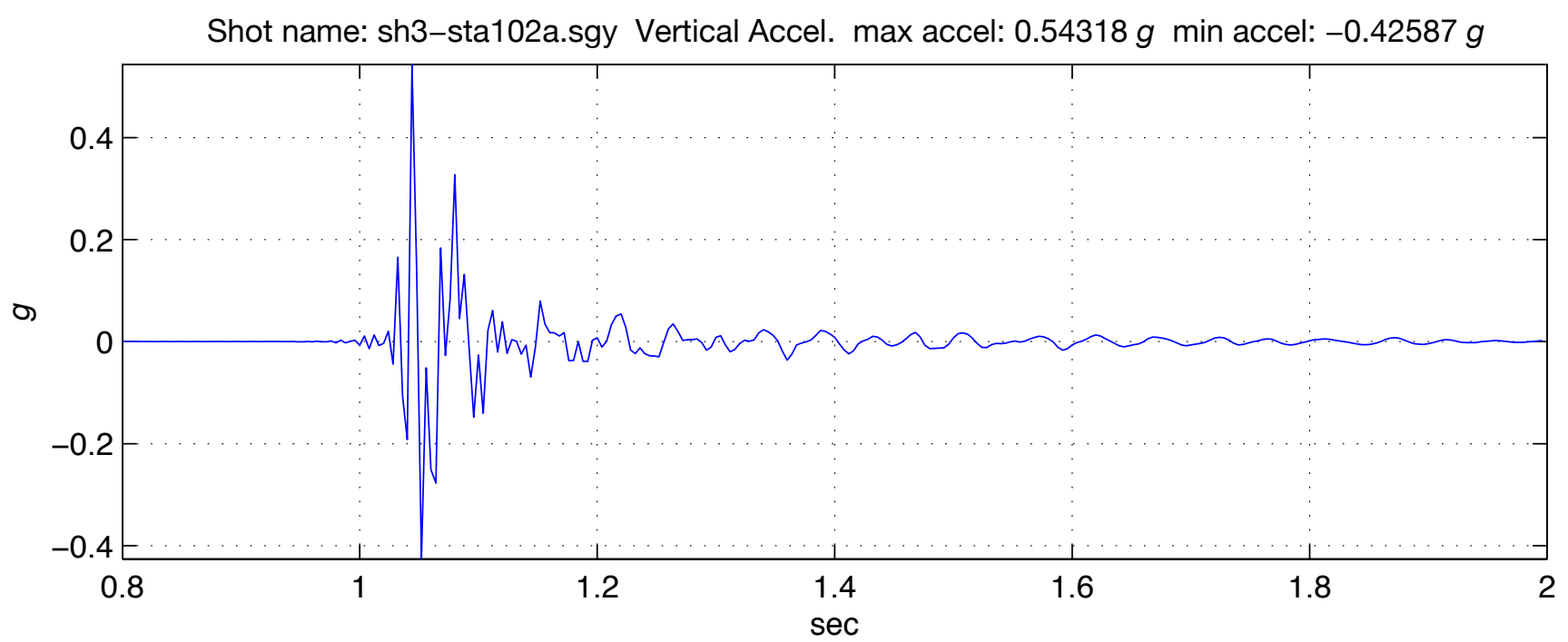

Shot name: sh3-sta102a.sgy Horizontal 1 Accel. max accel: $0.29632 \mathrm{~g}$ min accel: $-0.27405 \mathrm{~g}$

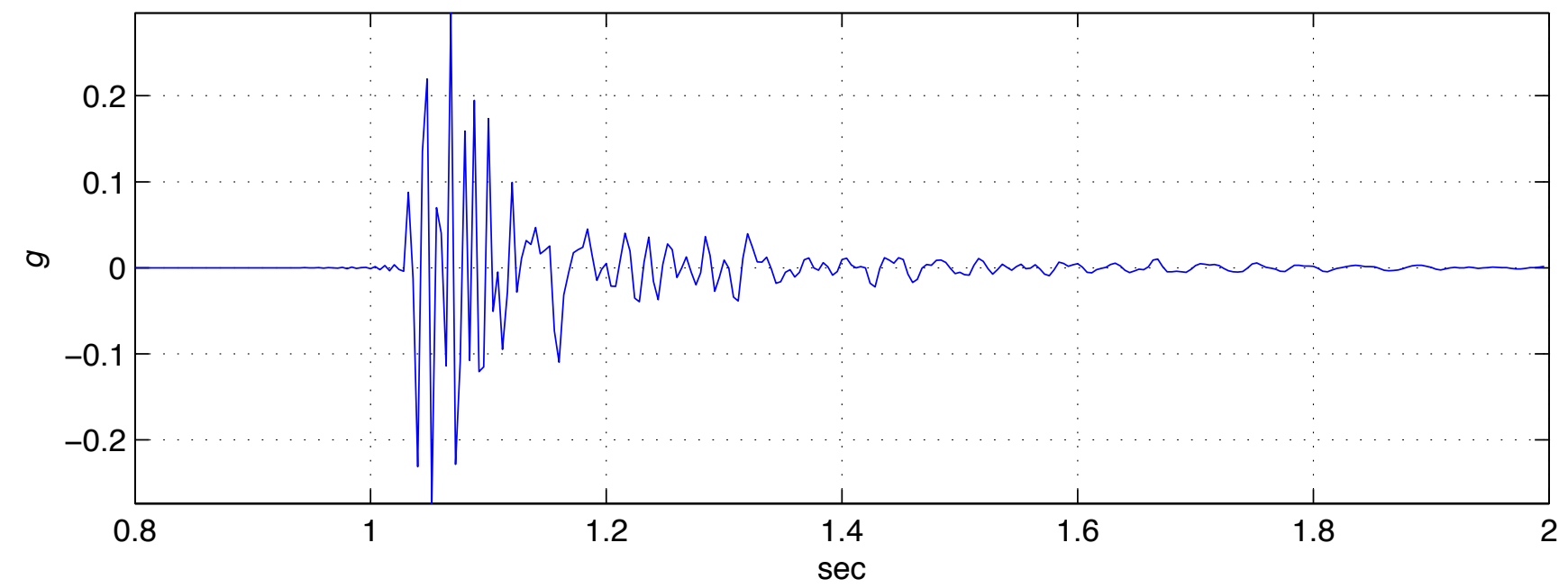

Shot name: sh3-sta102a.sgy Horizontal 2 Accel. max accel: $0.14863 \mathrm{~g}$ min accel: $-0.12876 \mathrm{~g}$

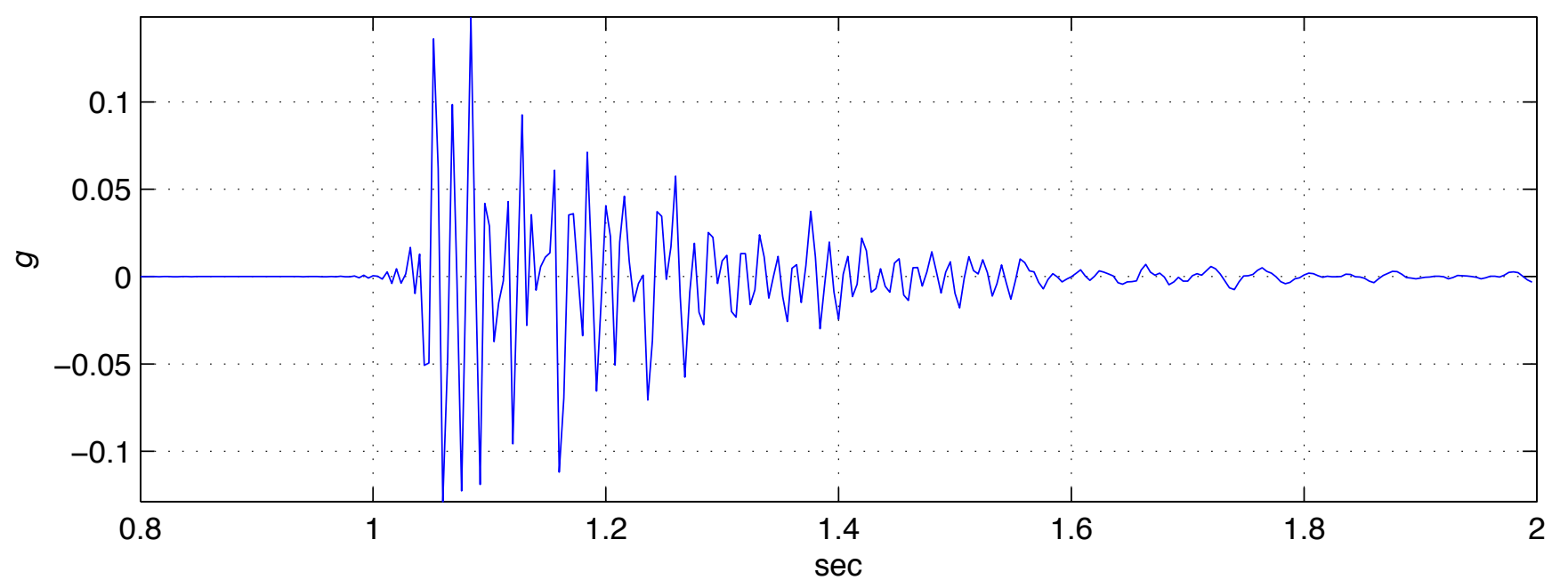


Shot name: sh3-sta103a.sgy Vertical Accel. max accel: $0.92661 \mathrm{~g}$ min accel: $-0.53563 \mathrm{~g}$

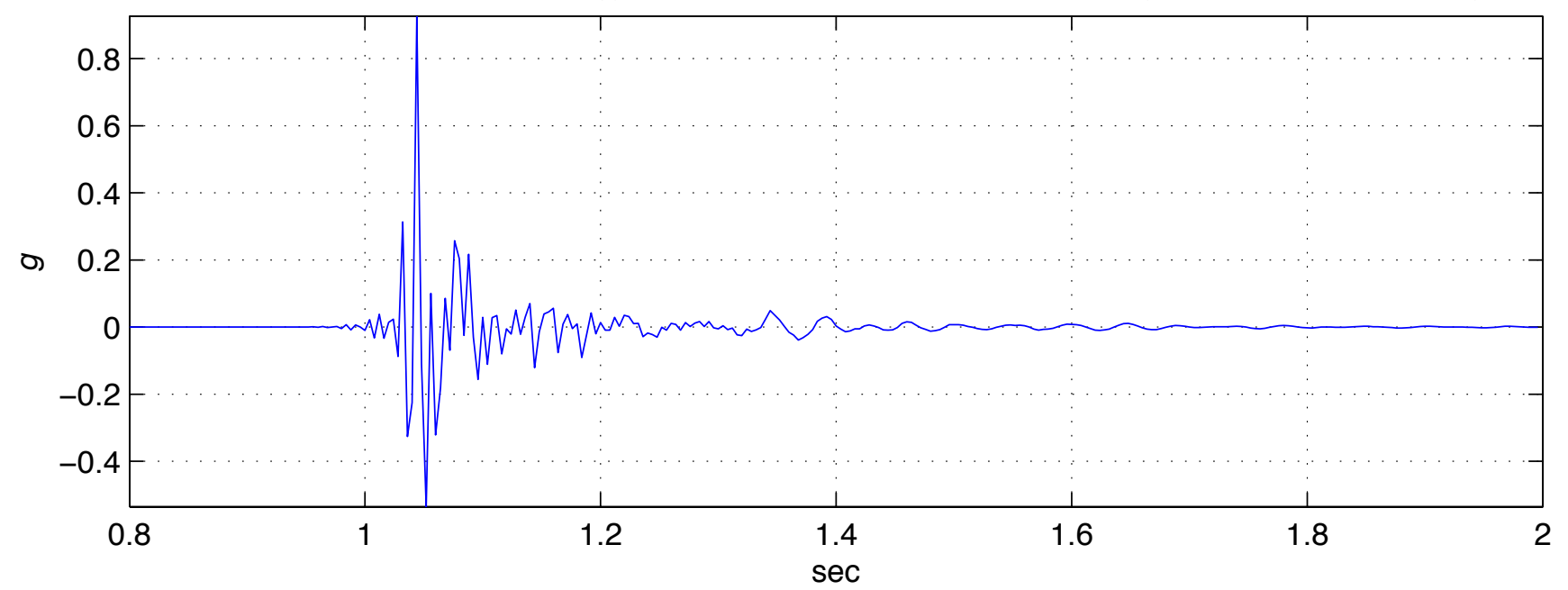

Shot name: sh3-sta103a.sgy Horizontal 1 Accel. max accel: $0.37998 \mathrm{~g}$ min accel: $-0.37937 \mathrm{~g}$

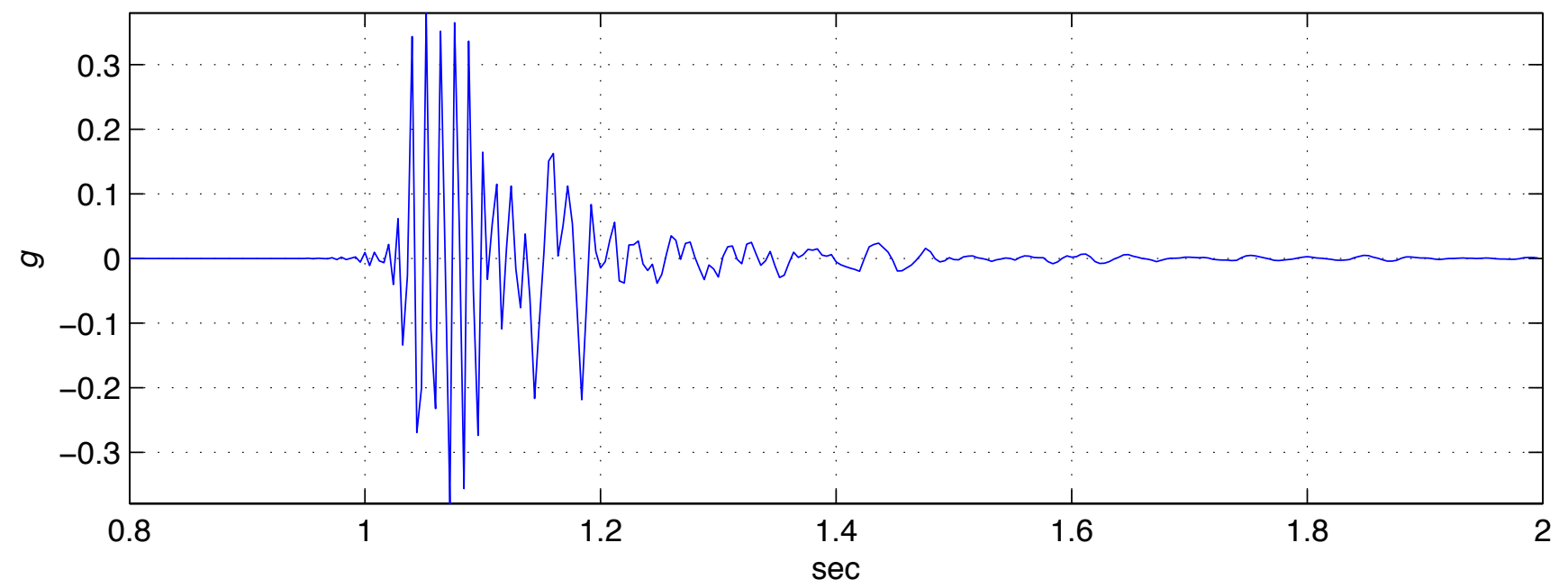

Shot name: sh3-sta103a.sgy Horizontal 2 Accel. max accel: $0.26189 \mathrm{~g}$ min accel: $-0.33247 \mathrm{~g}$

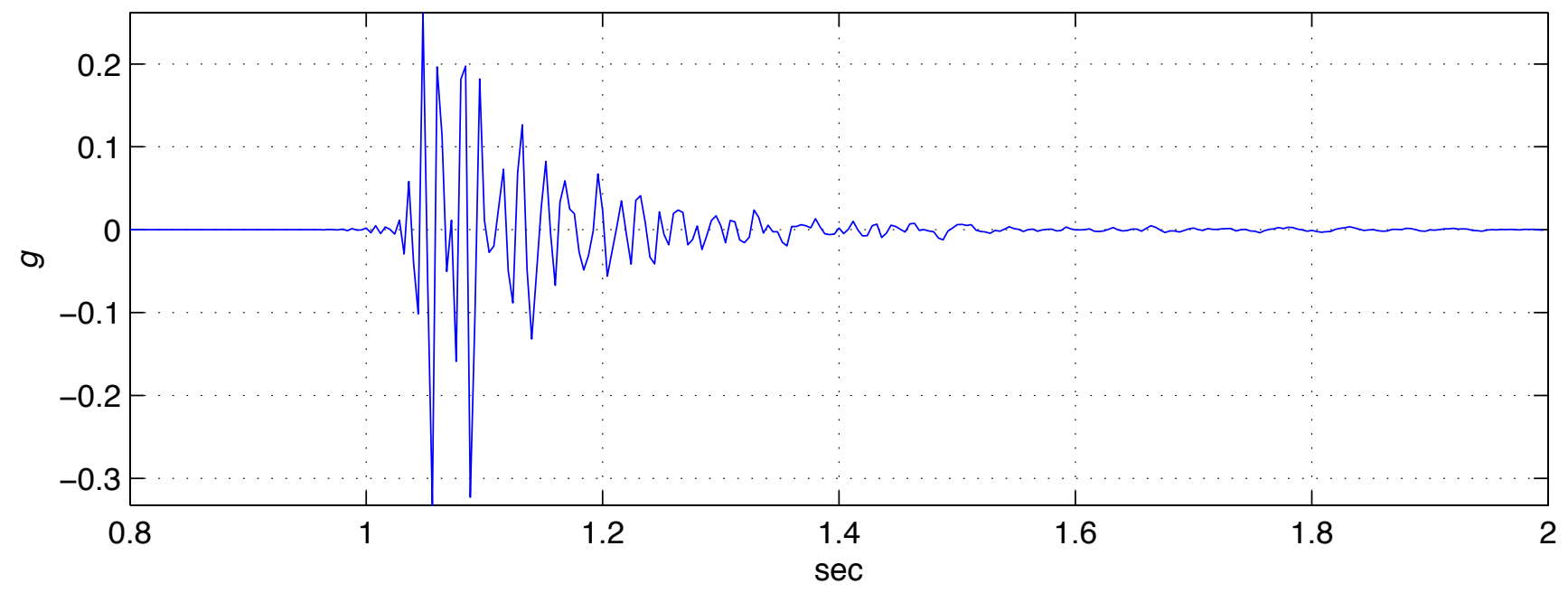




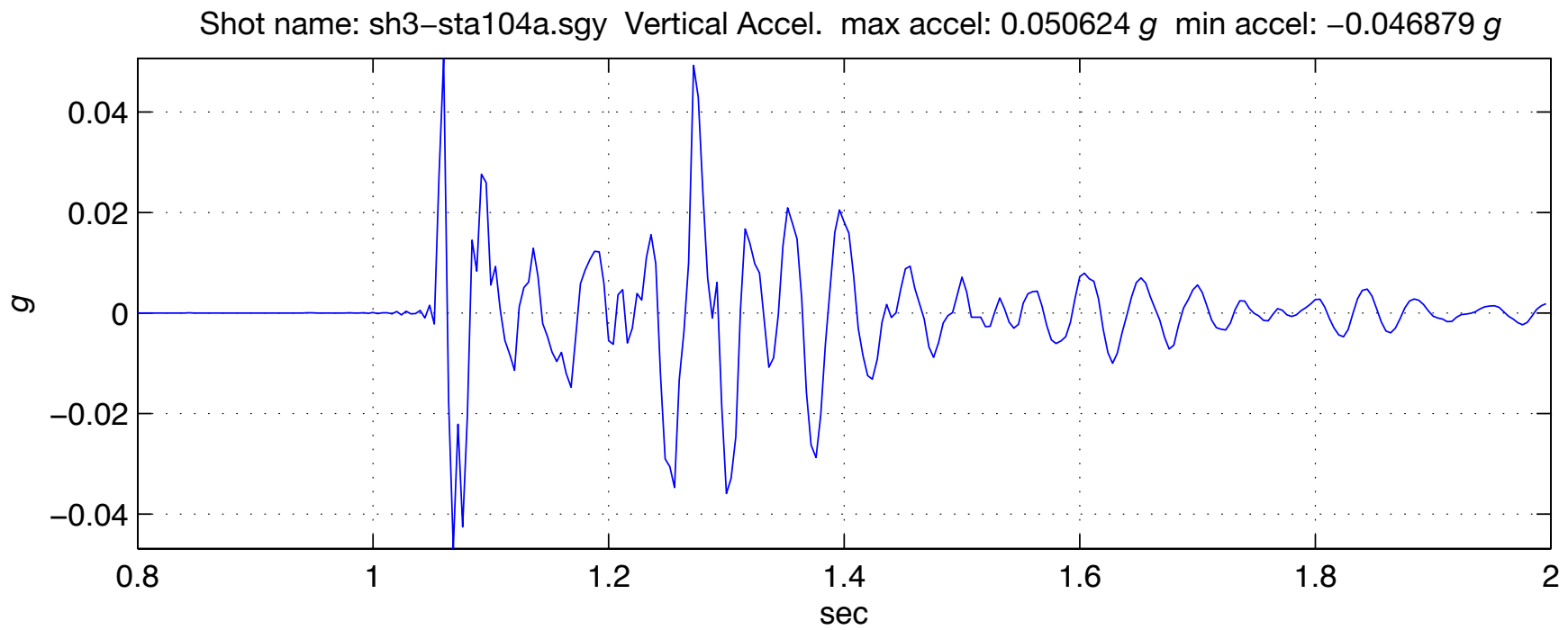

Shot name: sh3-sta104a.sgy Horizontal 1 Accel. max accel: $0.11427 \mathrm{~g}$ min accel: $-0.11515 \mathrm{~g}$

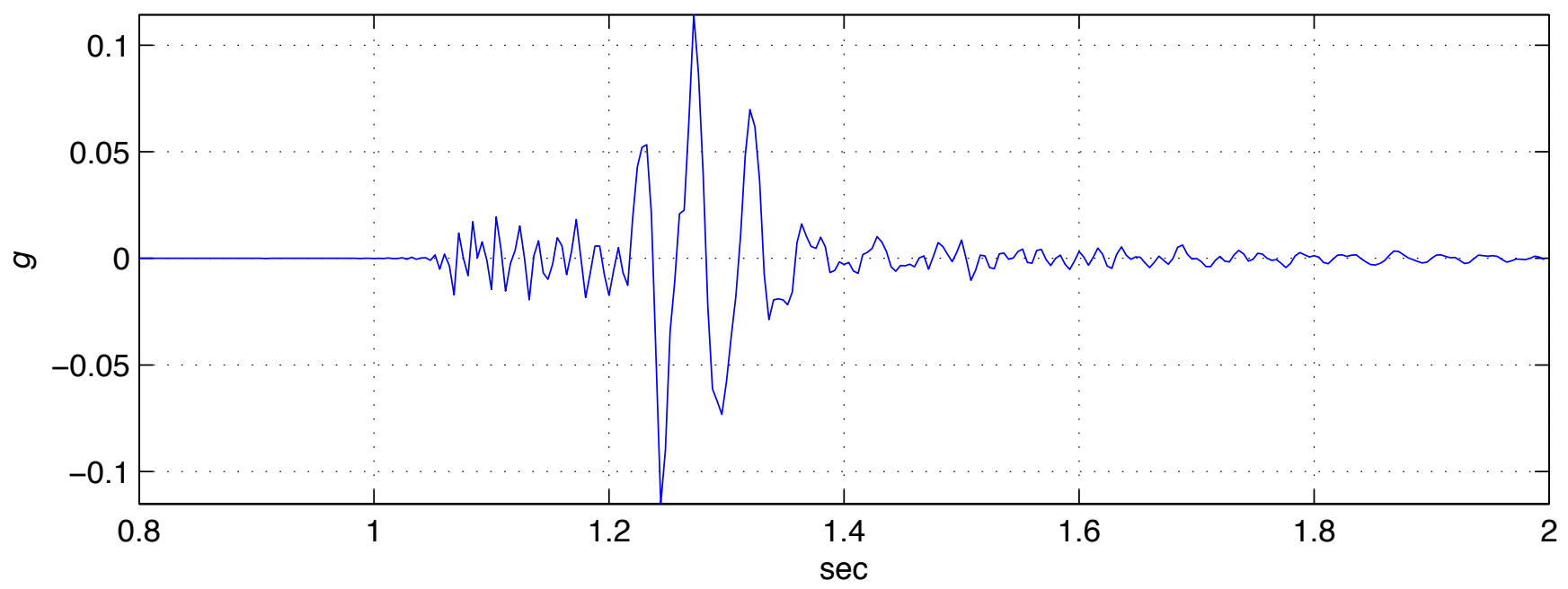

Shot name: sh3-sta104a.sgy Horizontal 2 Accel. max accel: $0.032153 \mathrm{~g}$ min accel: $-0.034139 \mathrm{~g}$

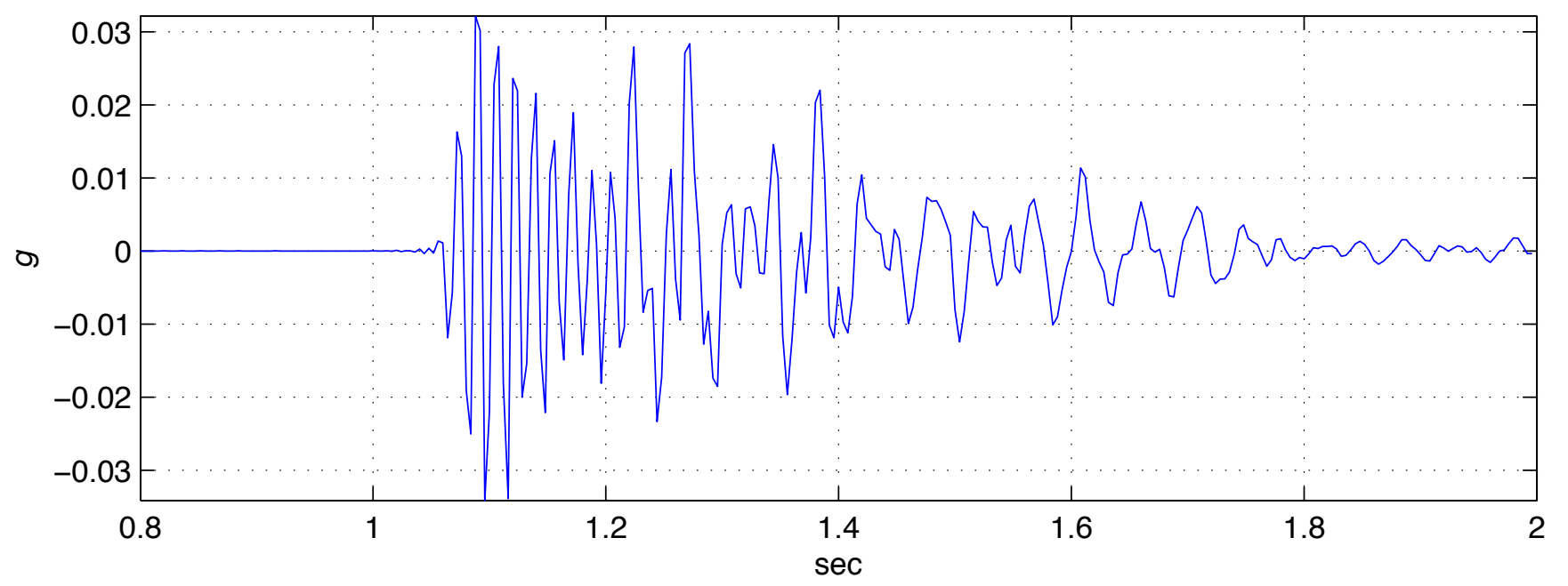


Shot name: sh3-sta105a.sgy Vertical Accel. max accel: $0.011611 \mathrm{~g}$ min accel: $-0.01403 \mathrm{~g}$

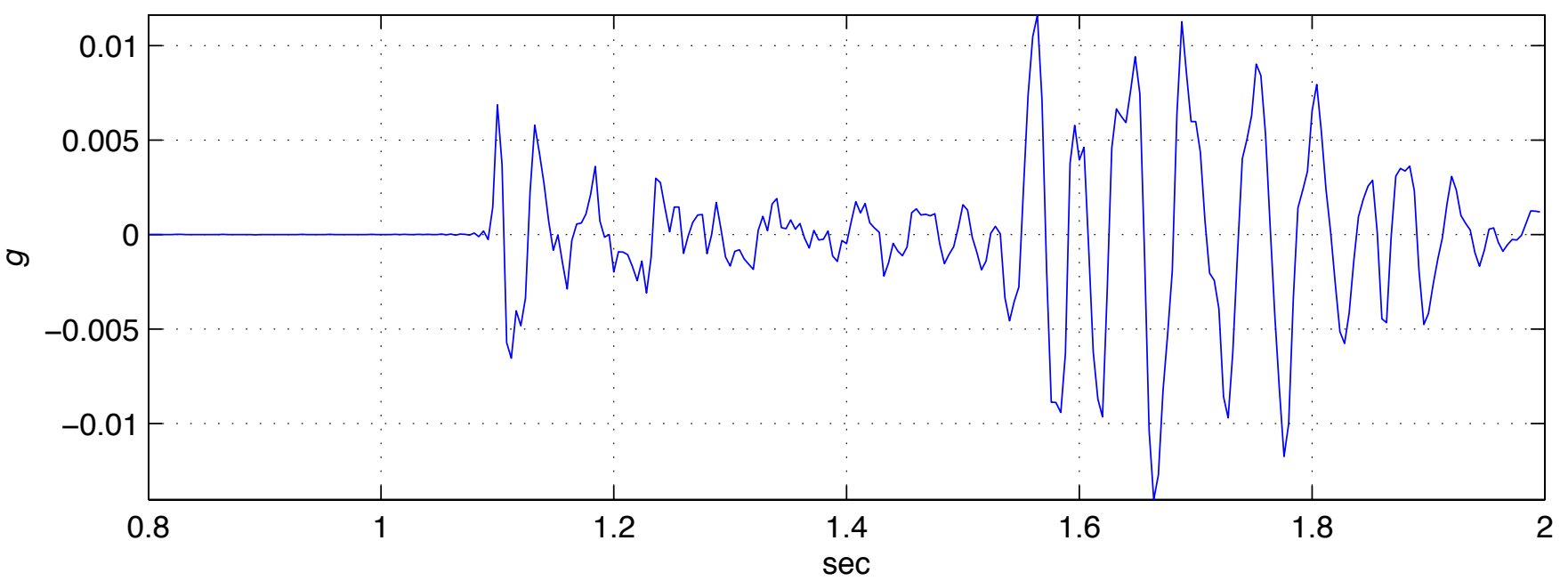

Shot name: sh3-sta105a.sgy Horizontal 1 Accel. max accel: $0.020581 \mathrm{~g}$ min accel: $-0.022062 \mathrm{~g}$

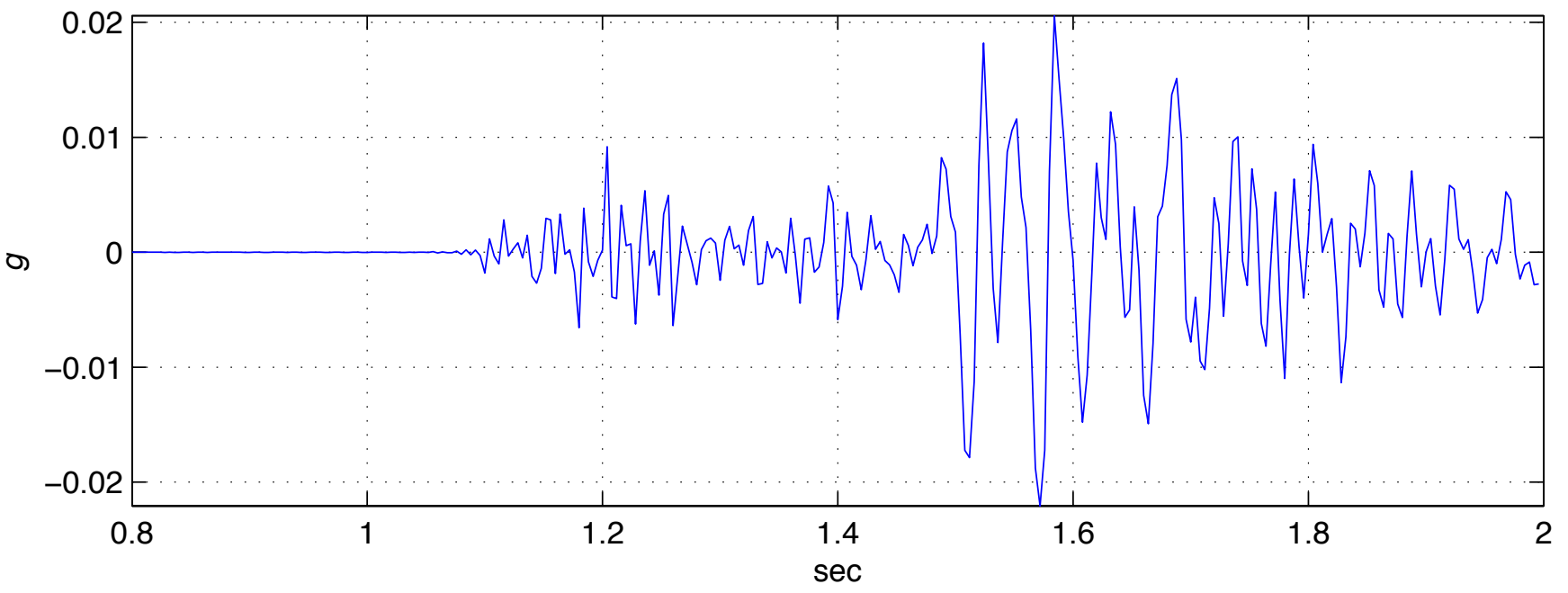

Shot name: sh3-sta105a.sgy Horizontal 2 Accel. max accel: $0.025004 \mathrm{~g}$ min accel: $-0.023456 \mathrm{~g}$

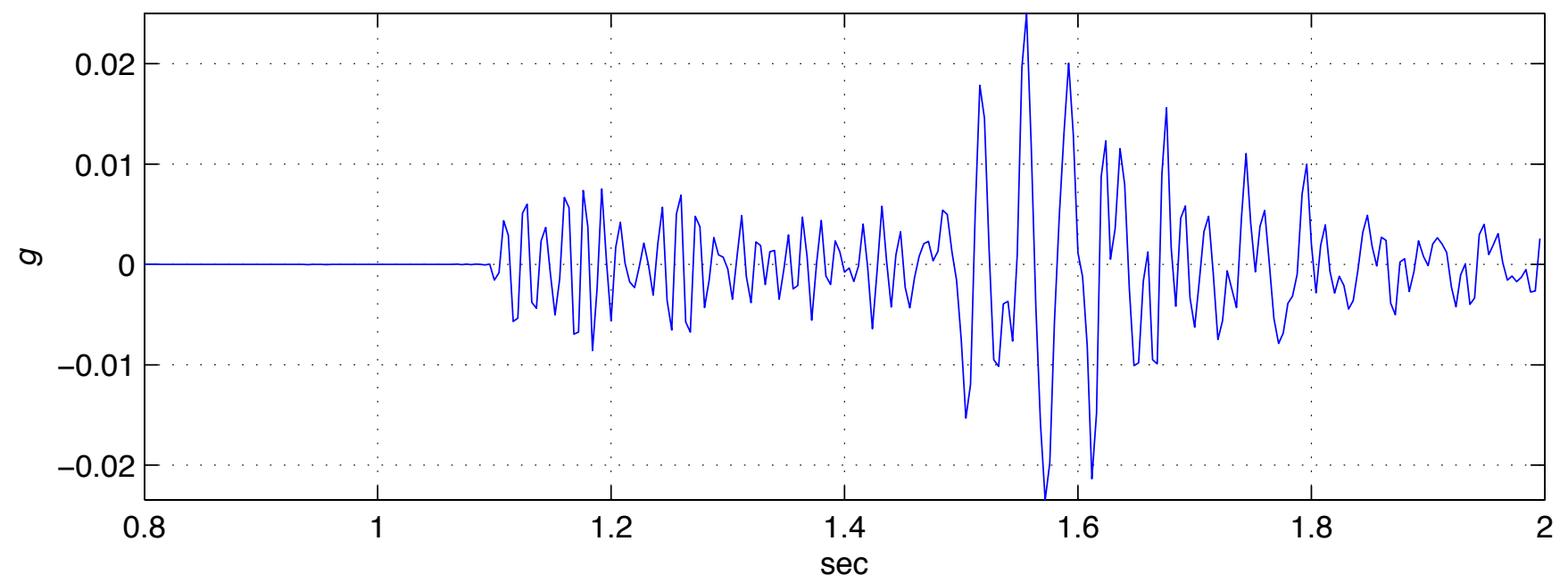




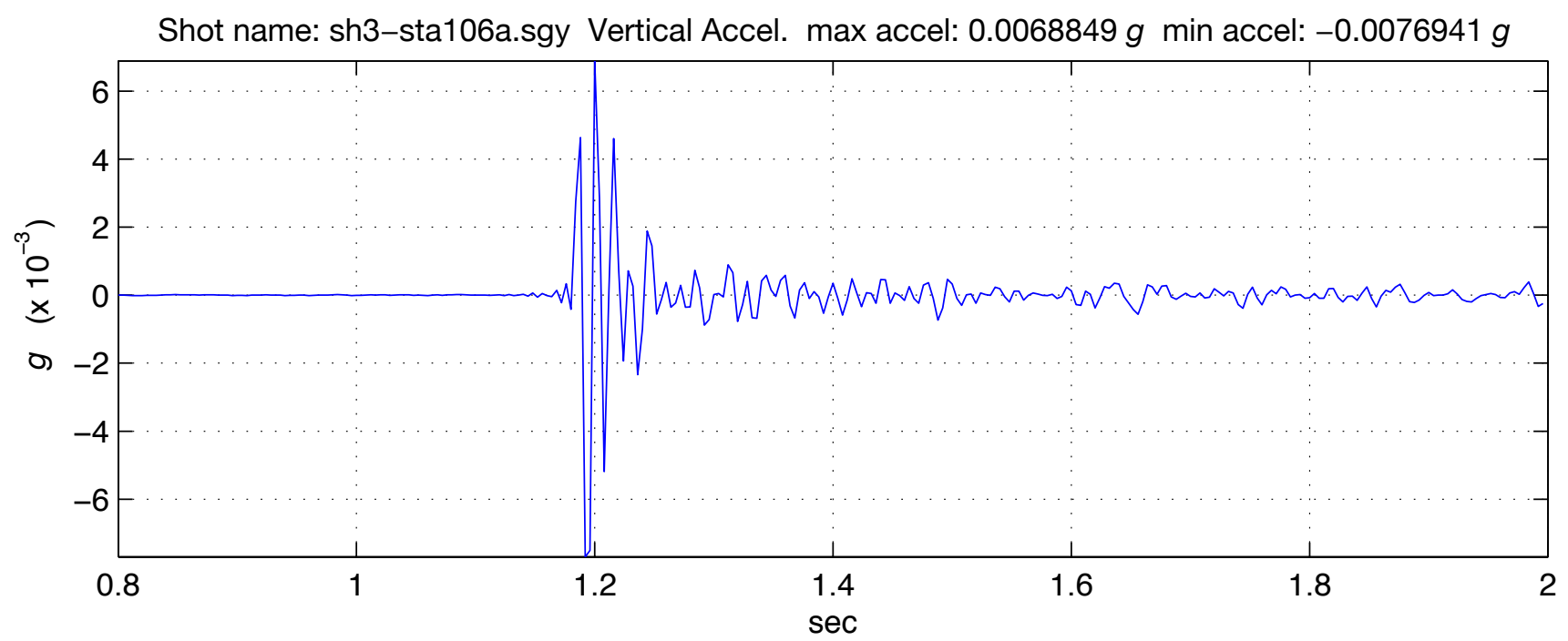

Shot name: sh3-sta106a.sgy Horizontal 1 Accel. max accel: $0.0068325 \mathrm{~g}$ min accel: $-0.0080585 \mathrm{~g}$

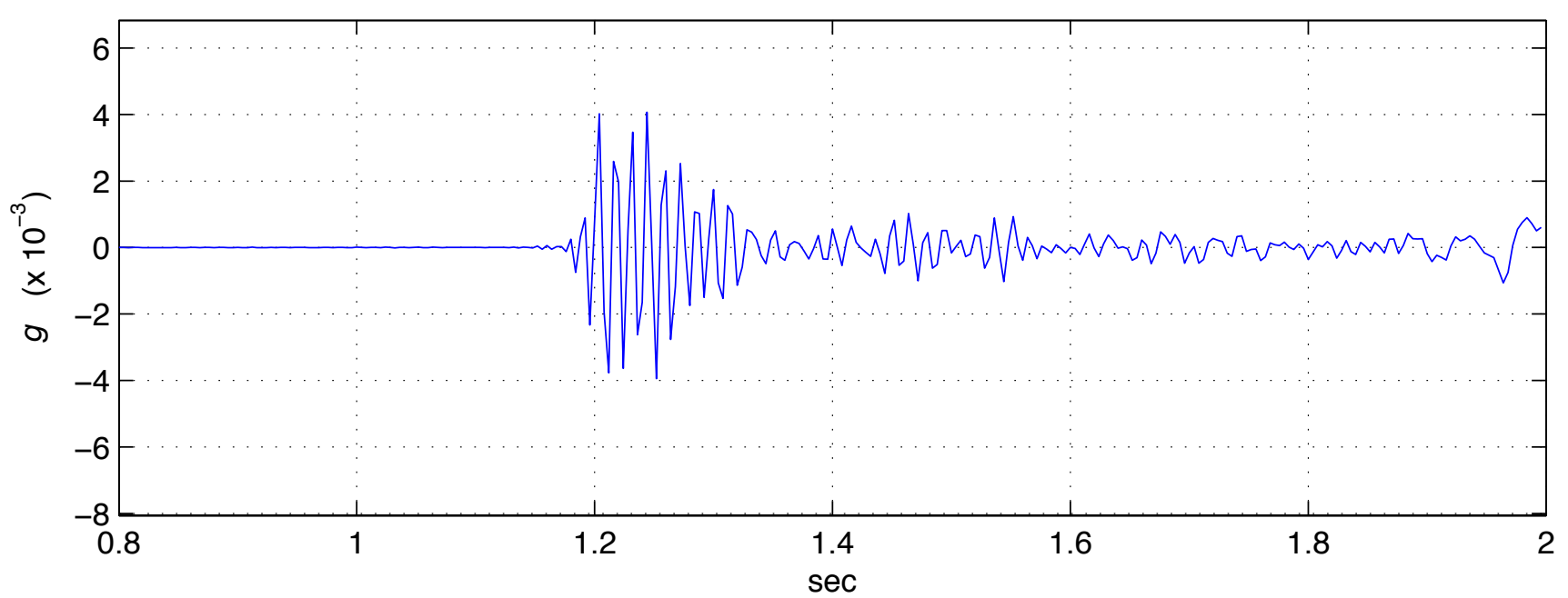

Shot name: sh3-sta106a.sgy Horizontal 2 Accel. max accel: $0.0050784 \mathrm{~g}$ min accel: $-0.0061159 \mathrm{~g}$

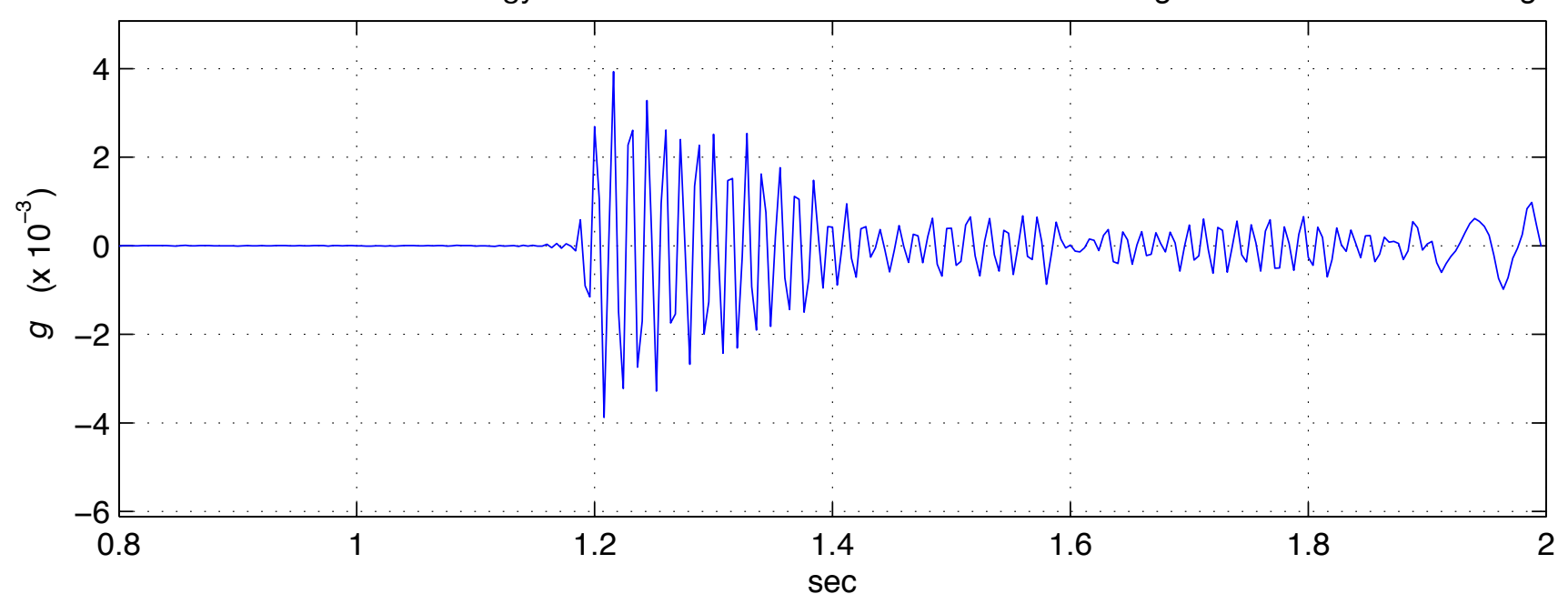


Appendix 3b. Near Source Velocity Plots

[From 6-component RefTeks] 


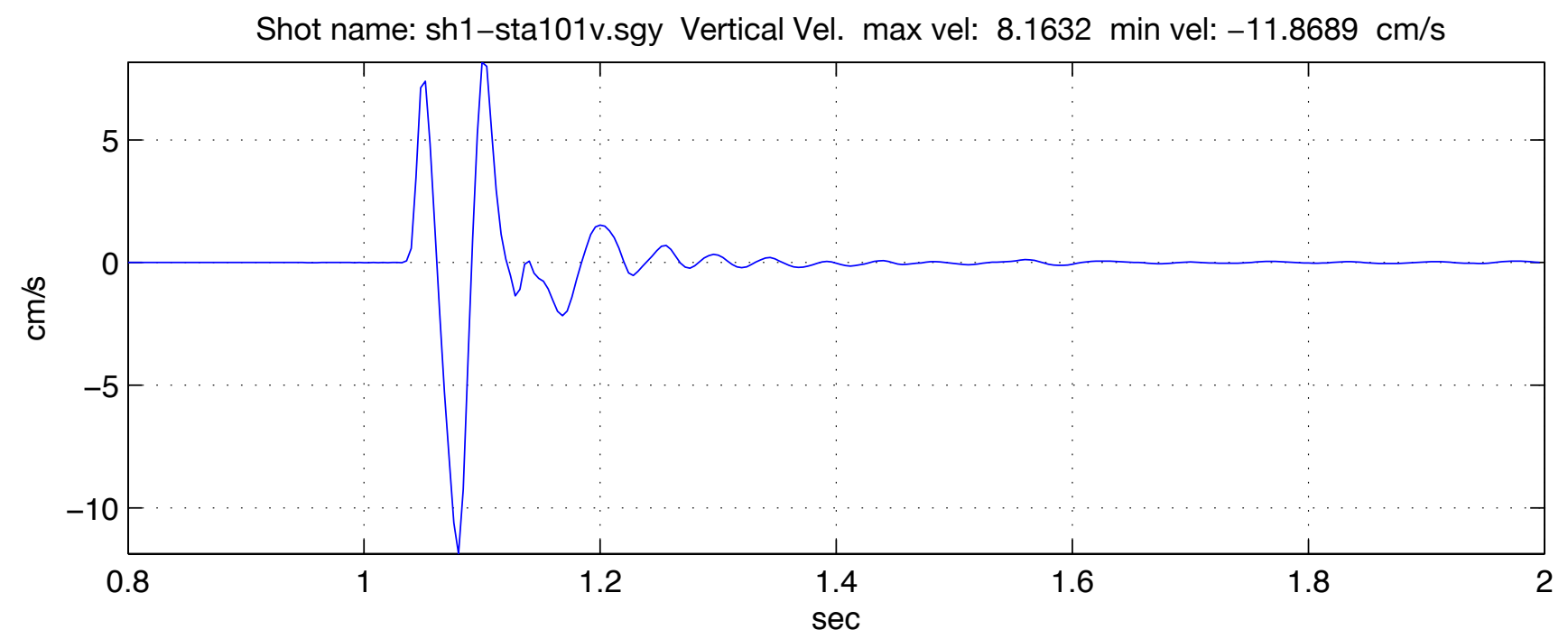

Shot name: sh1-sta101v.sgy Horizontal 1 Vel. max vel: 2.2437 min vel: $-1.6223 \mathrm{~cm} / \mathrm{s}$

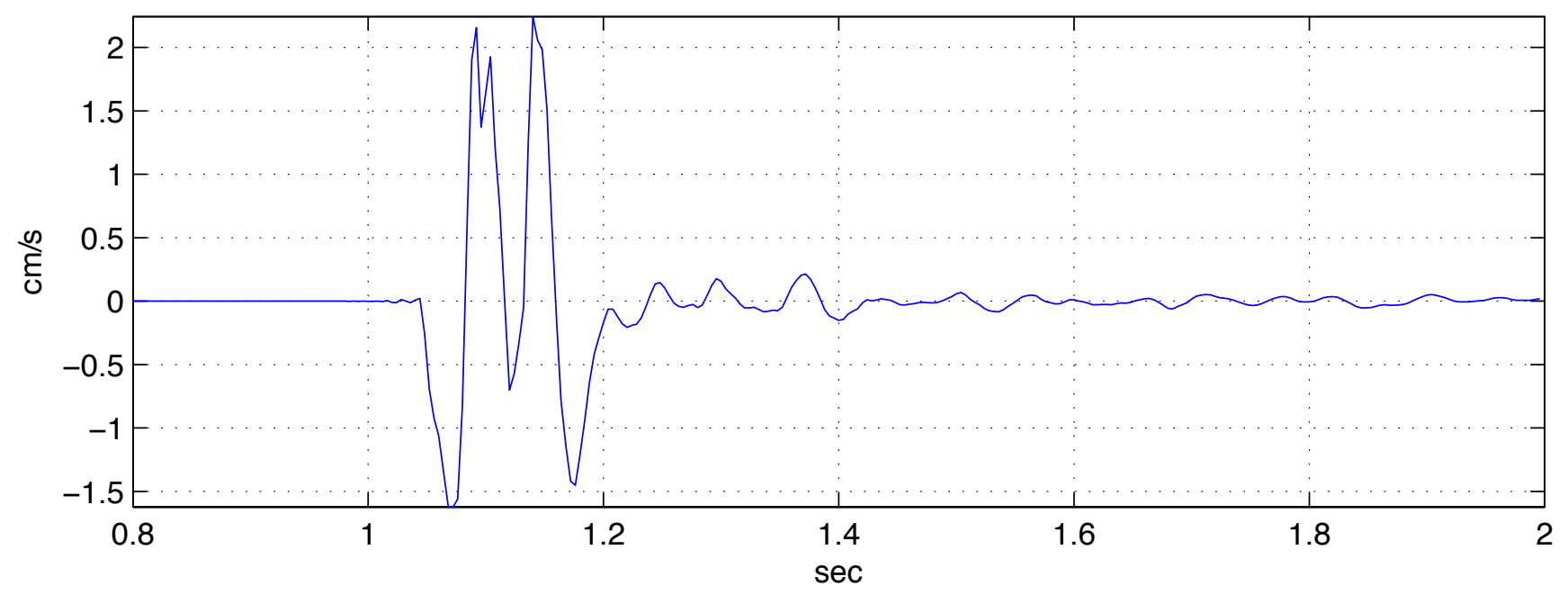

Shot name: sh1-sta101v.sgy Horizontal 2 Vel. max vel: $1.0516 \mathrm{~min}$ vel: $-1.6924 \mathrm{~cm} / \mathrm{s}$

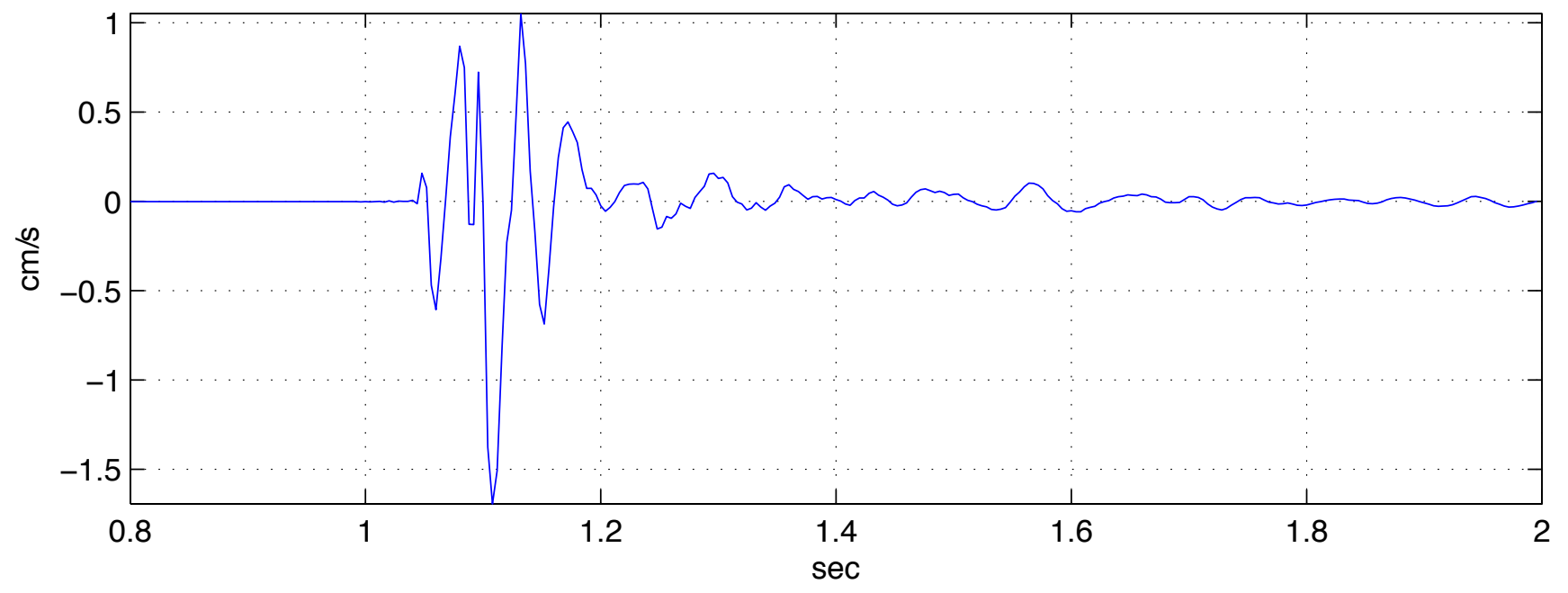


Shot name: sh1-sta102v.sgy Vertical Vel. max vel: $2.7096 \mathrm{~min}$ vel: $-3.4673 \mathrm{~cm} / \mathrm{s}$

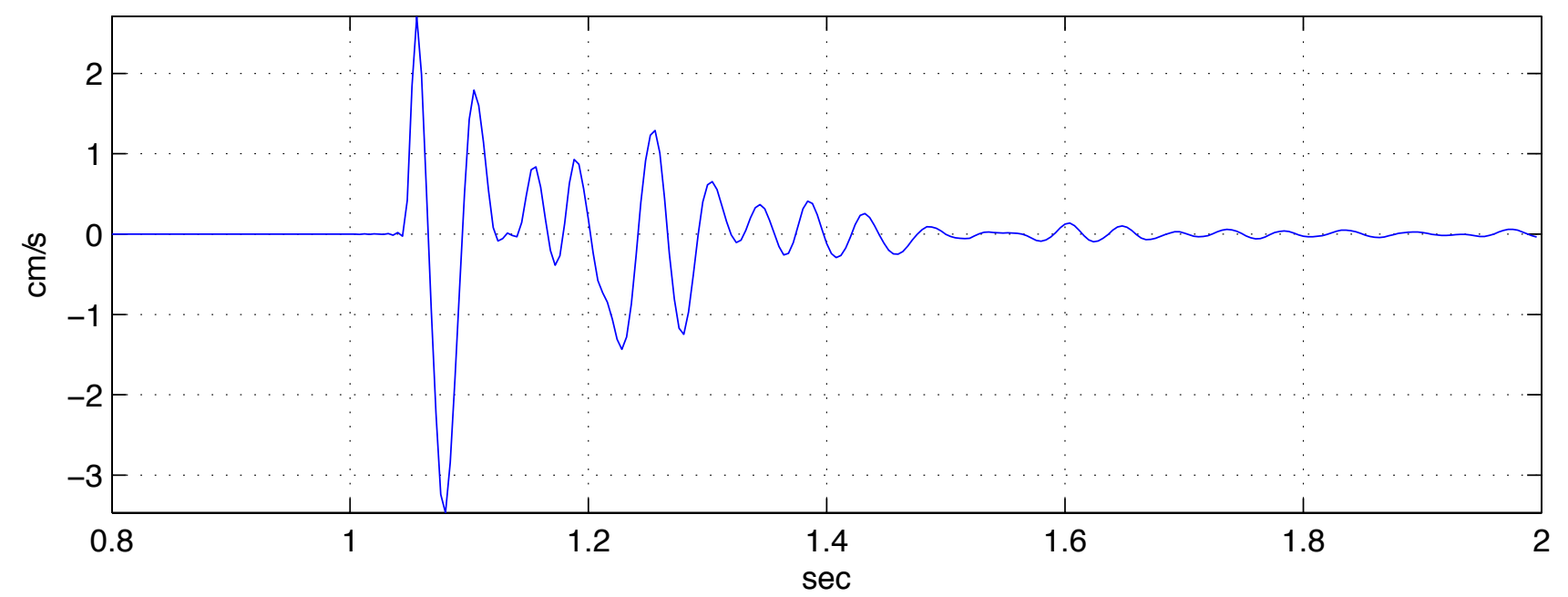

Shot name: sh1-sta102v.sgy Horizontal 1 Vel. max vel: 0.77965 min vel: $-0.69544 \mathrm{~cm} / \mathrm{s}$
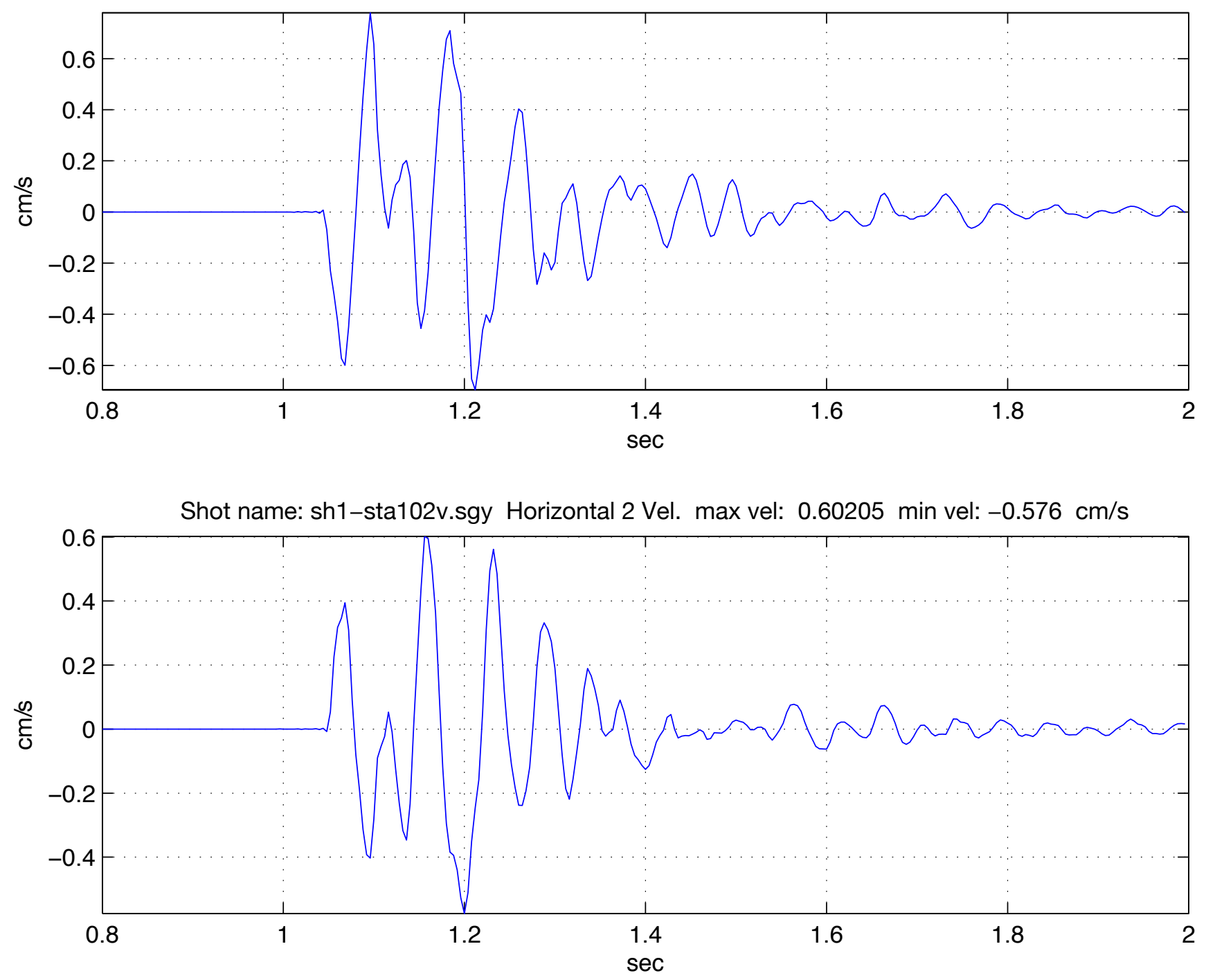
Shot name: sh1-sta103v.sgy Vertical Vel. max vel: 1.1973 min vel: $-1.1437 \mathrm{~cm} / \mathrm{s}$

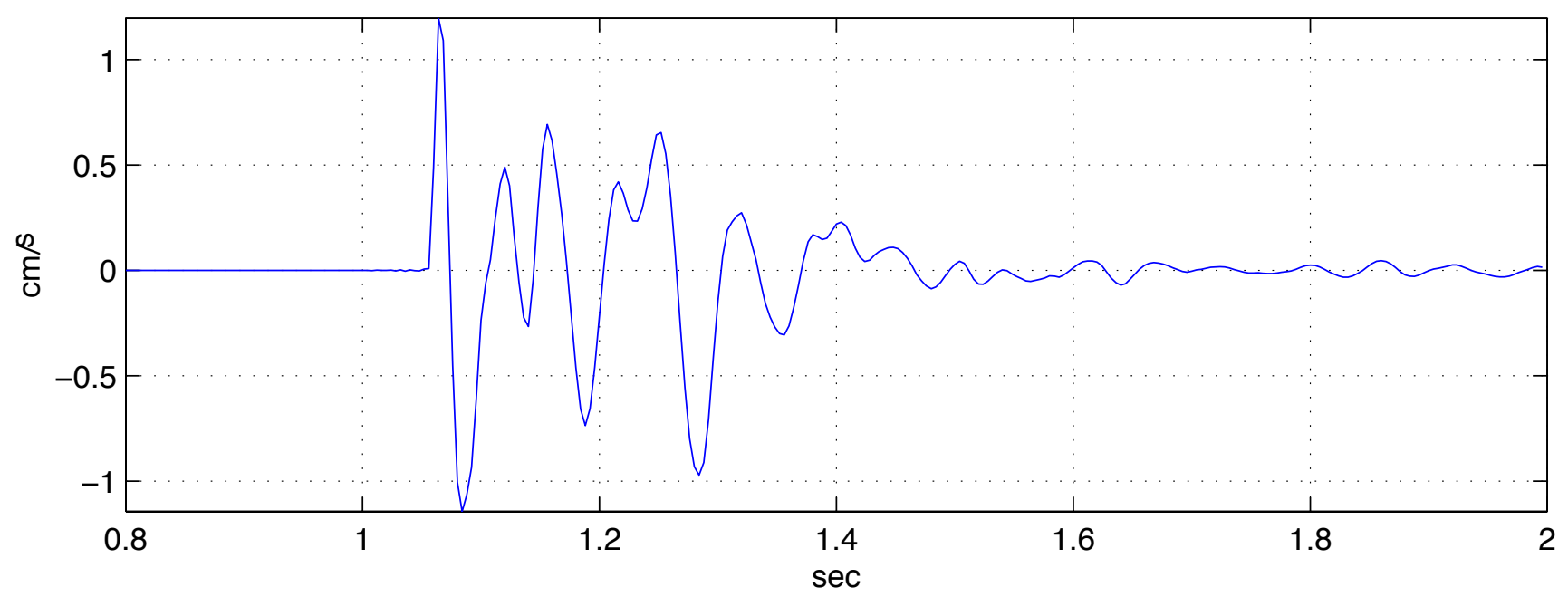

Shot name: sh1-sta103v.sgy Horizontal 1 Vel. max vel: 0.88548 min vel: $-0.70255 \mathrm{~cm} / \mathrm{s}$

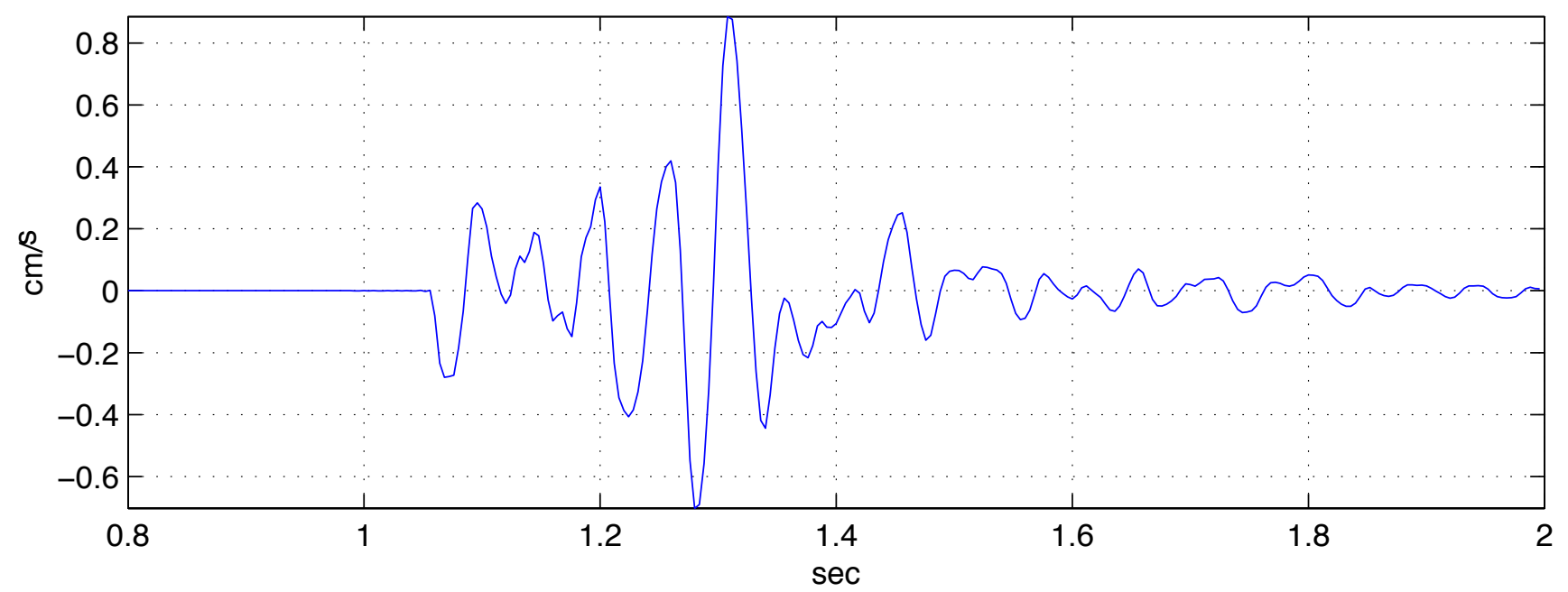

Shot name: sh1-sta103v.sgy Horizontal 2 Vel. max vel: 0.29224 min vel: $-0.32123 \mathrm{~cm} / \mathrm{s}$

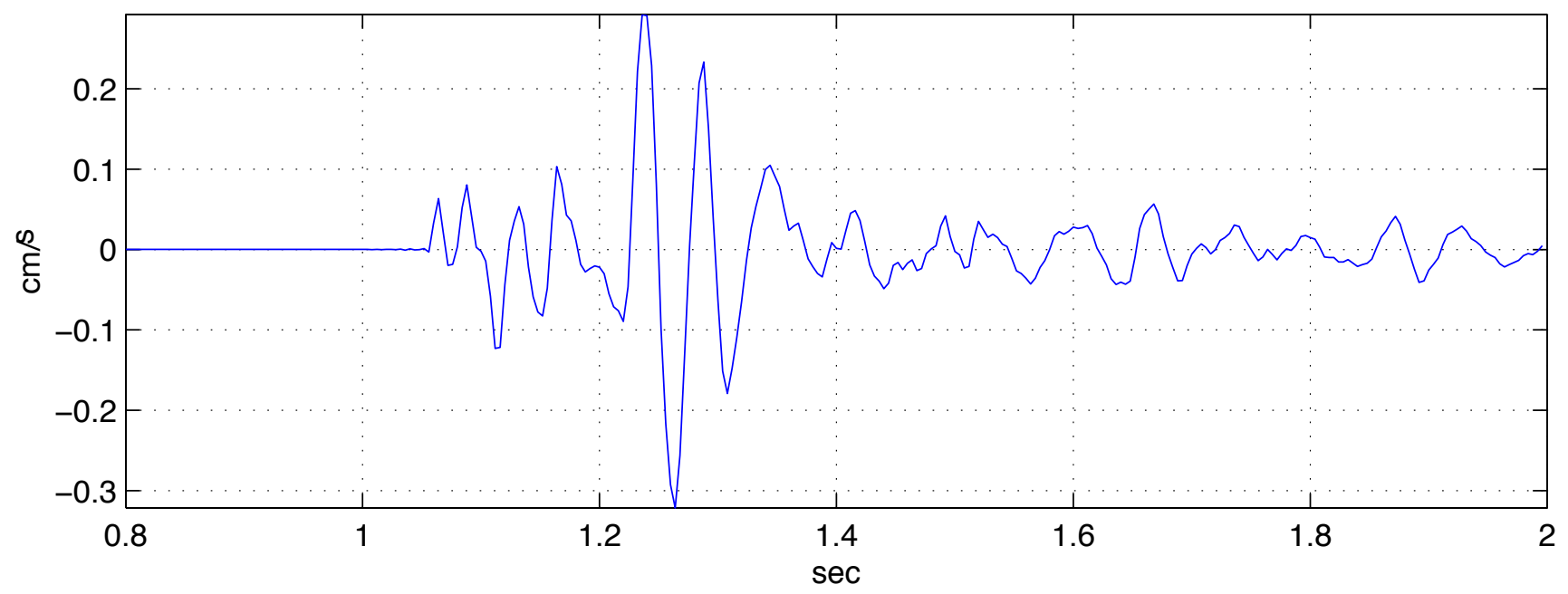




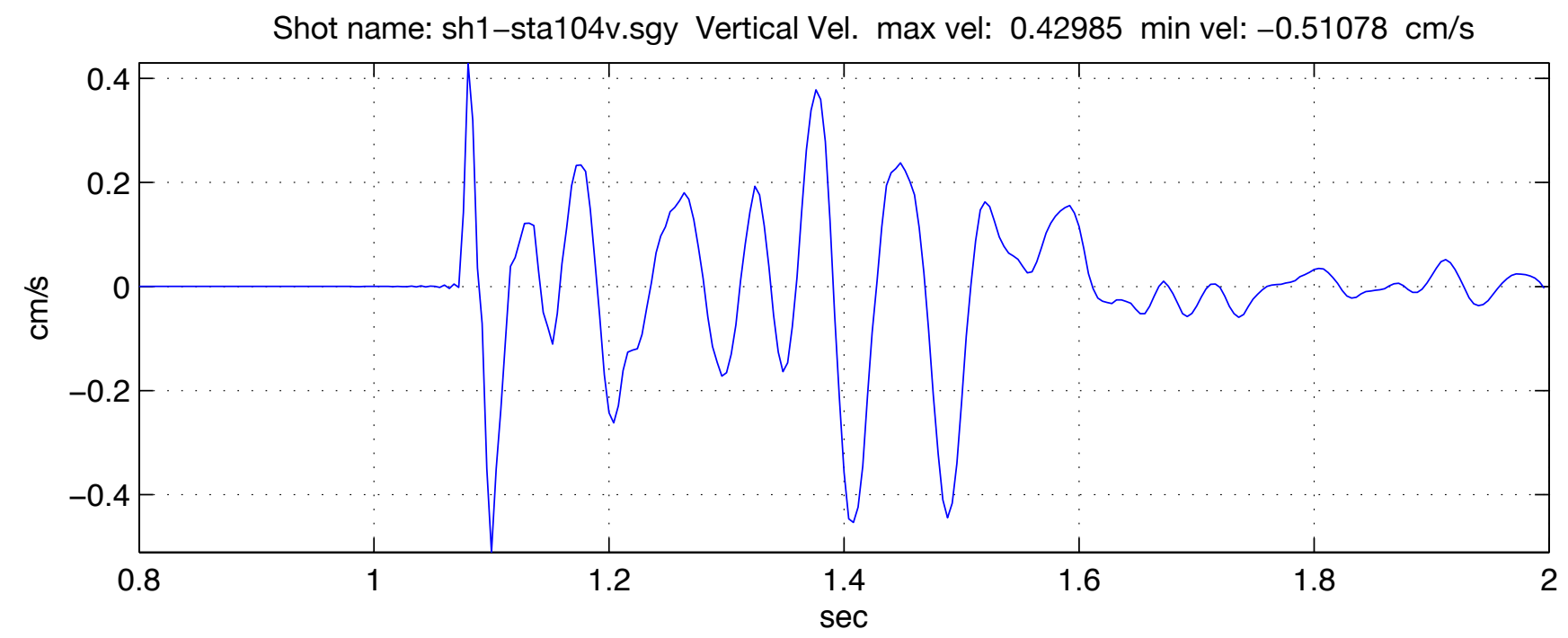

Shot name: sh1-sta104v.sgy Horizontal 1 Vel. max vel: 0.33867 min vel: $-0.19282 \mathrm{~cm} / \mathrm{s}$

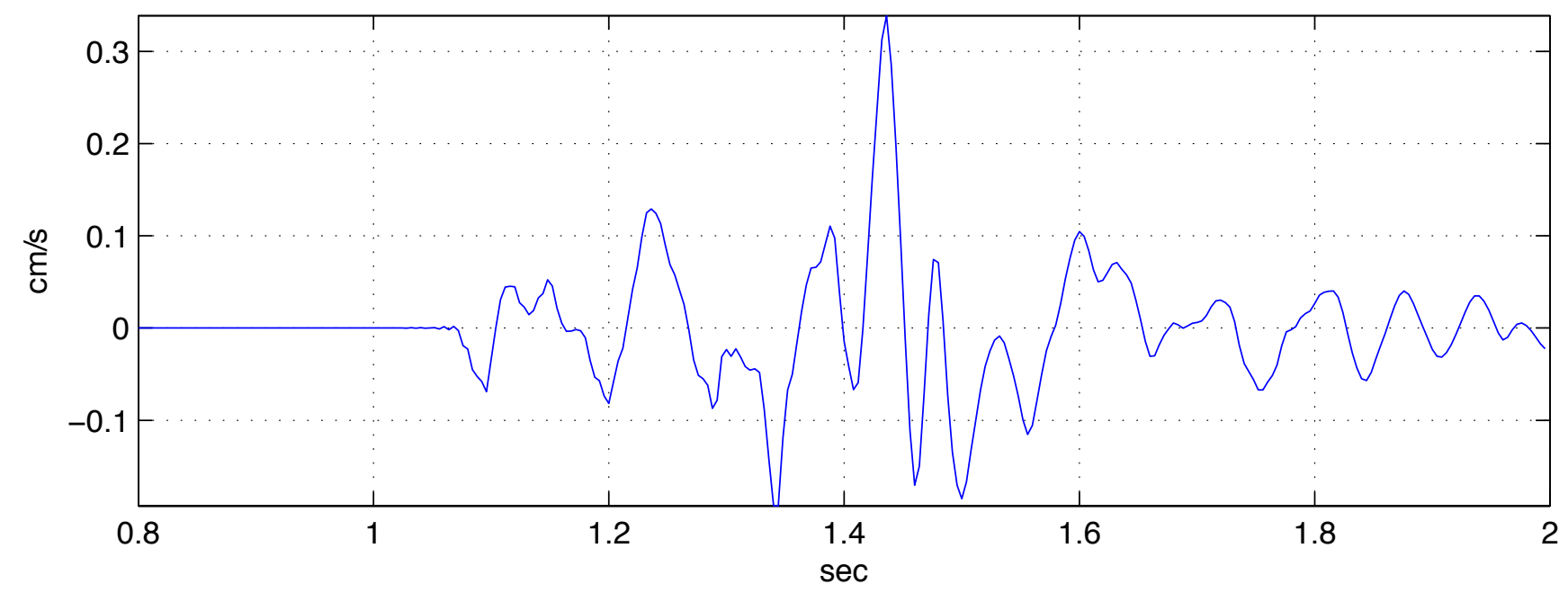

Shot name: sh1-sta104v.sgy Horizontal 2 Vel. max vel: 0.099723 min vel: $-0.094694 \mathrm{~cm} / \mathrm{s}$

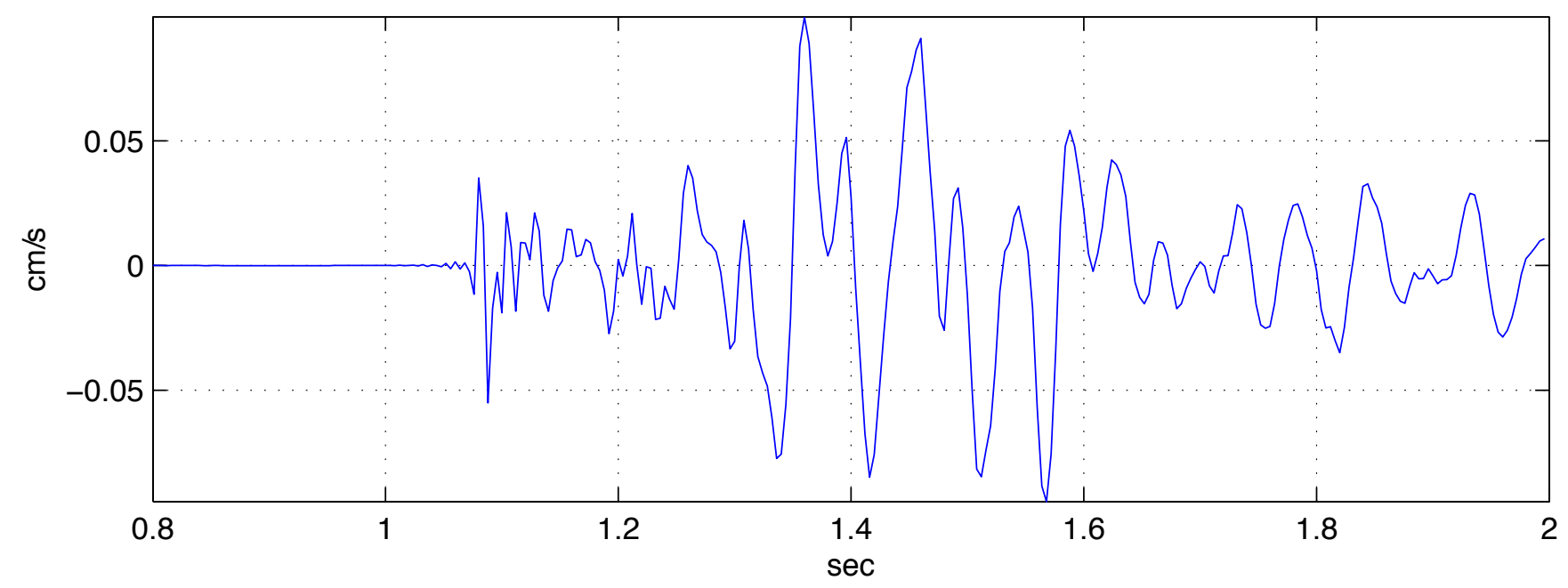


Shot name: sh1-sta105v.sgy Vertical Vel. max vel: $0.16521 \mathrm{~min}$ vel: $-0.28563 \mathrm{~cm} / \mathrm{s}$
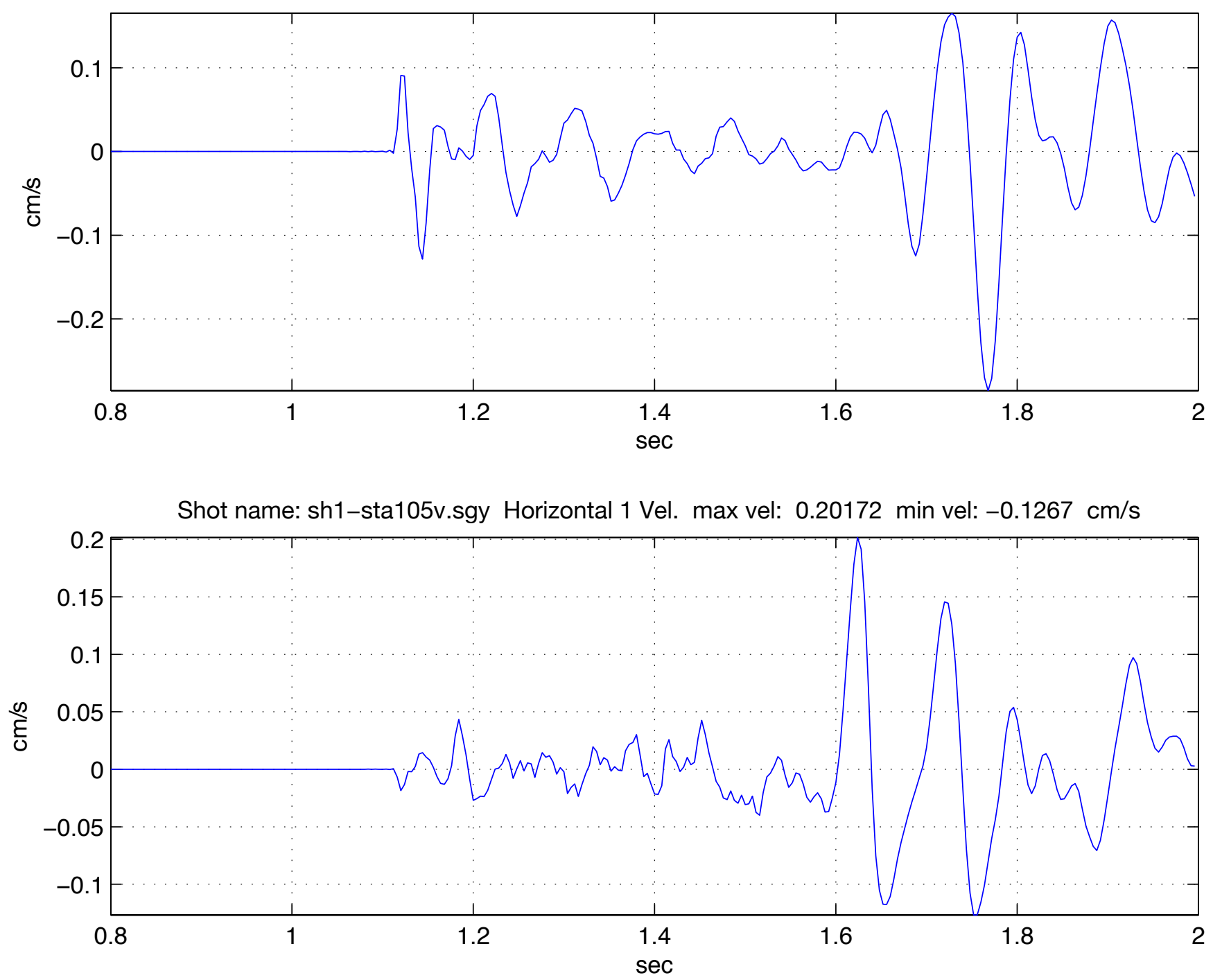

Shot name: sh1-sta105v.sgy Horizontal 2 Vel. max vel: 0.19049 min vel: $-0.14243 \mathrm{~cm} / \mathrm{s}$

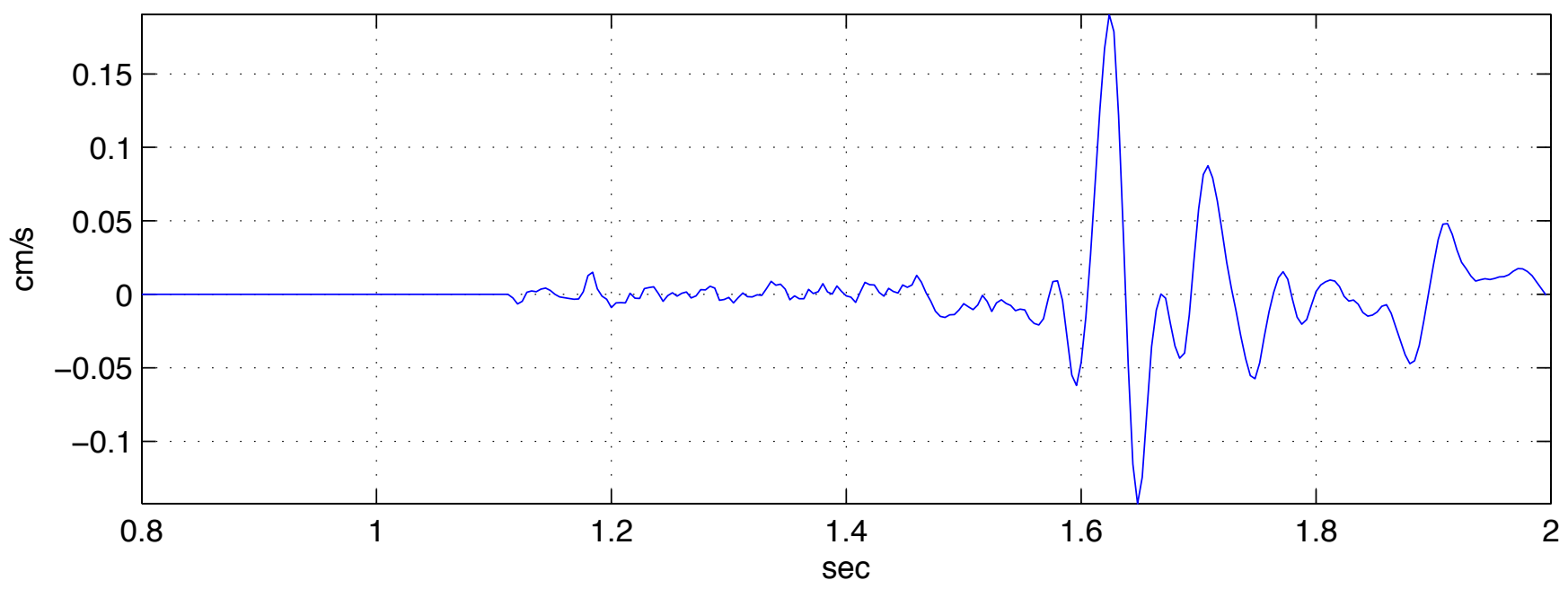



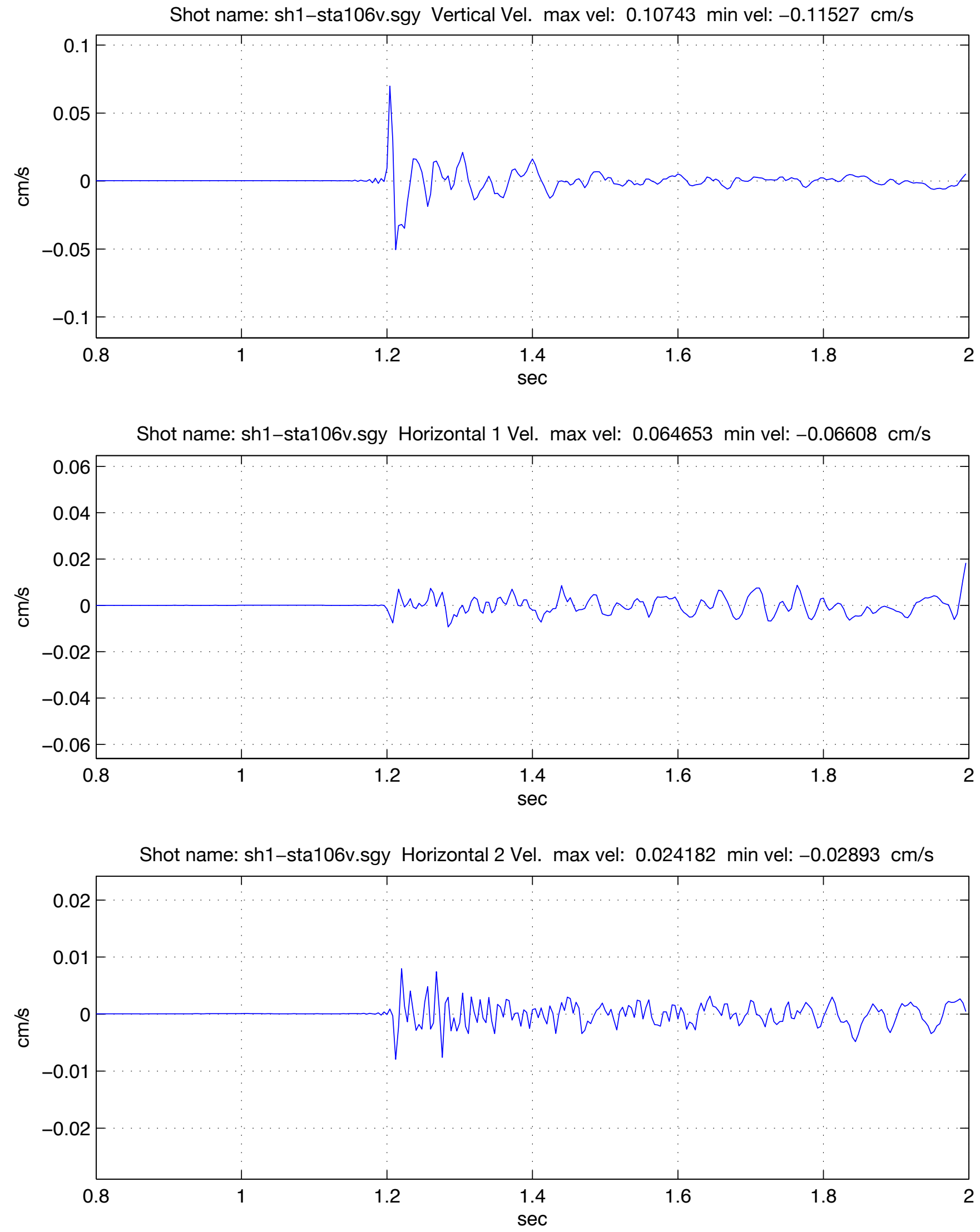


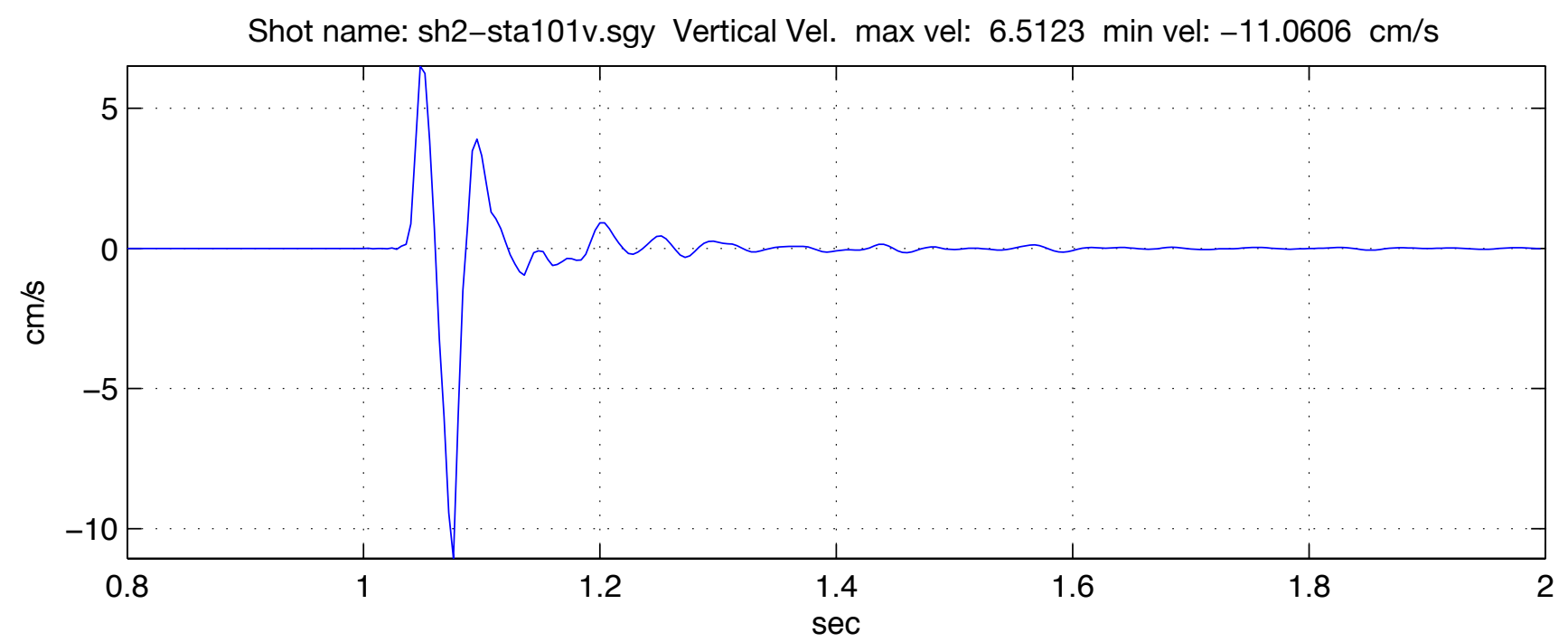

Shot name: sh2-sta101v.sgy Horizontal 1 Vel. max vel: $0.94176 \min$ vel: $-1.3825 \mathrm{~cm} / \mathrm{s}$

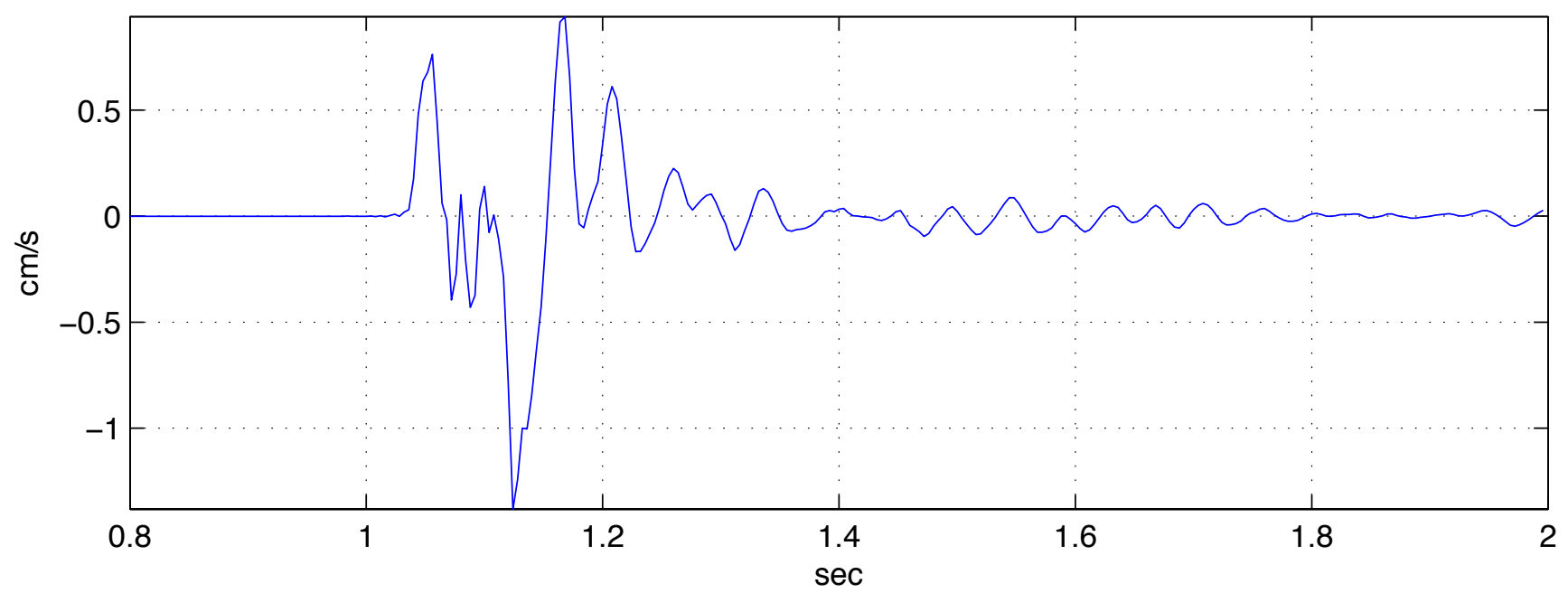

Shot name: sh2-sta101v.sgy Horizontal 2 Vel. max vel: 1.5979 min vel: $-1.263 \mathrm{~cm} / \mathrm{s}$

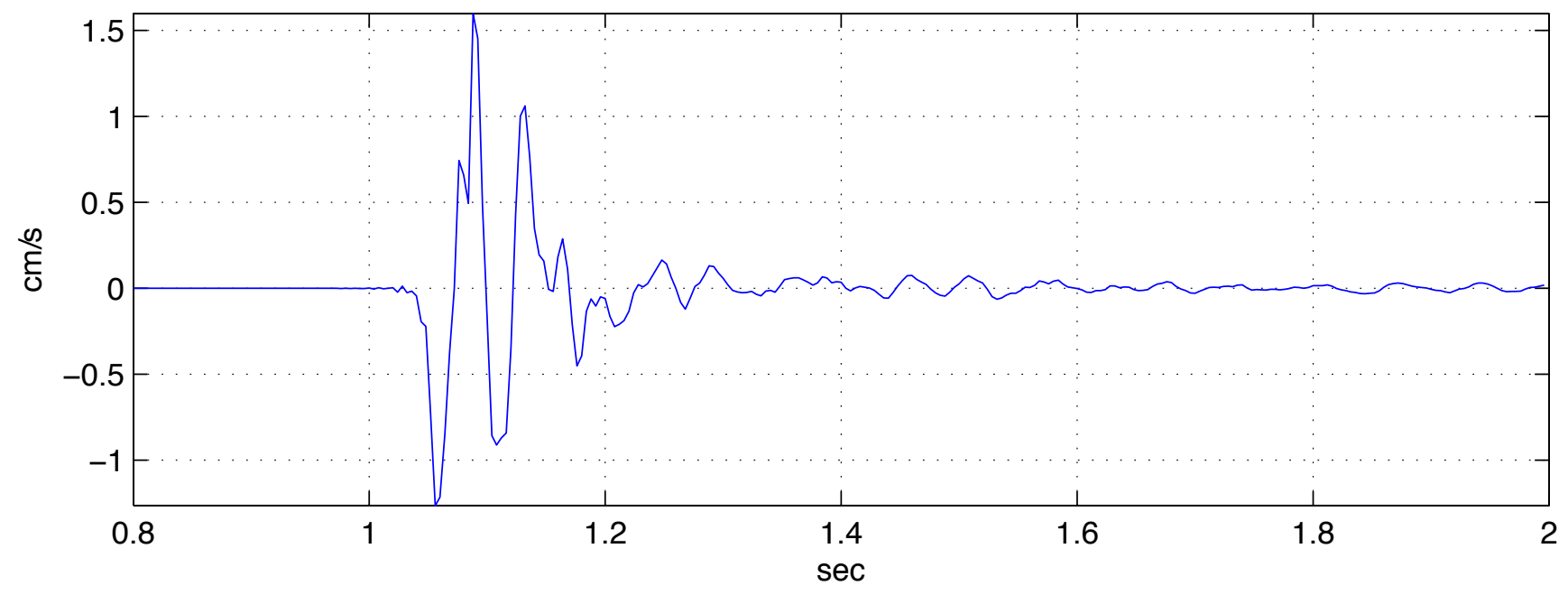




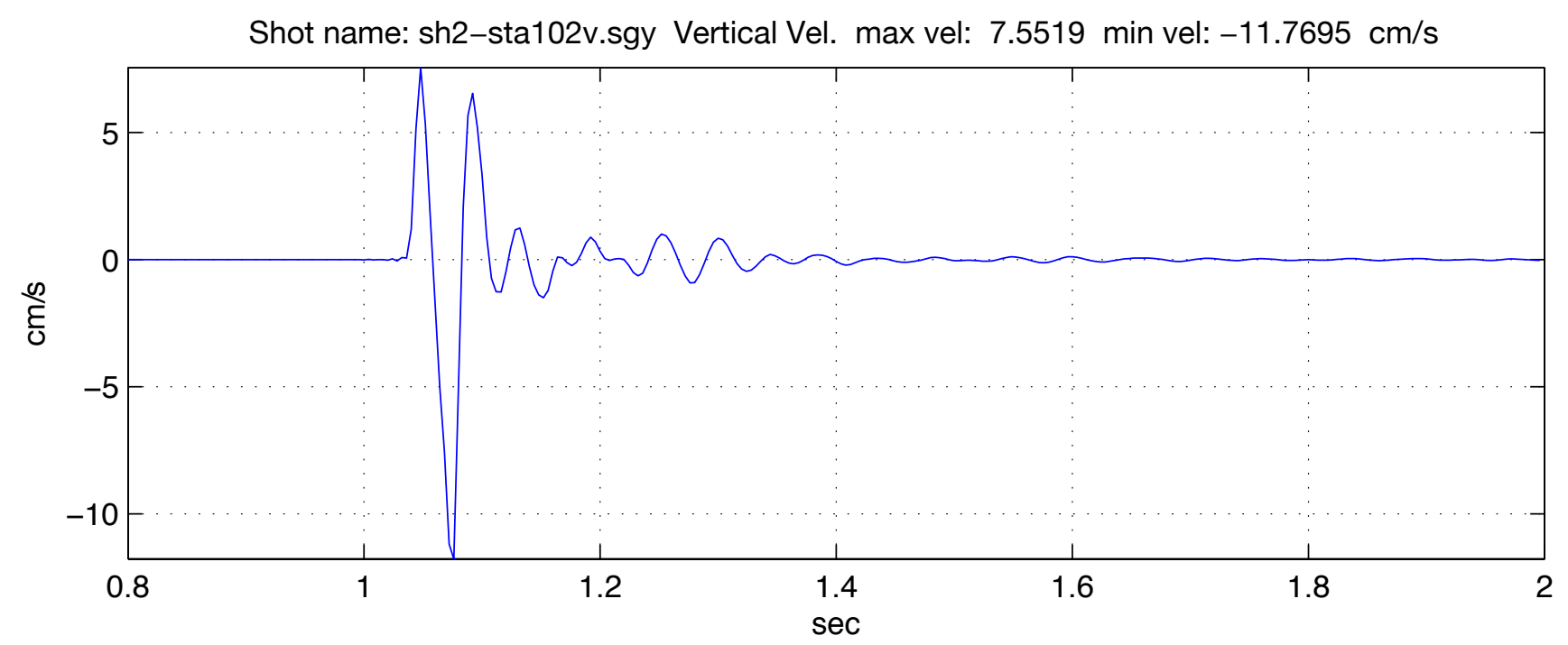

Shot name: sh2-sta102v.sgy Horizontal 1 Vel. max vel: 1.3429 min vel: $-0.60779 \mathrm{~cm} / \mathrm{s}$

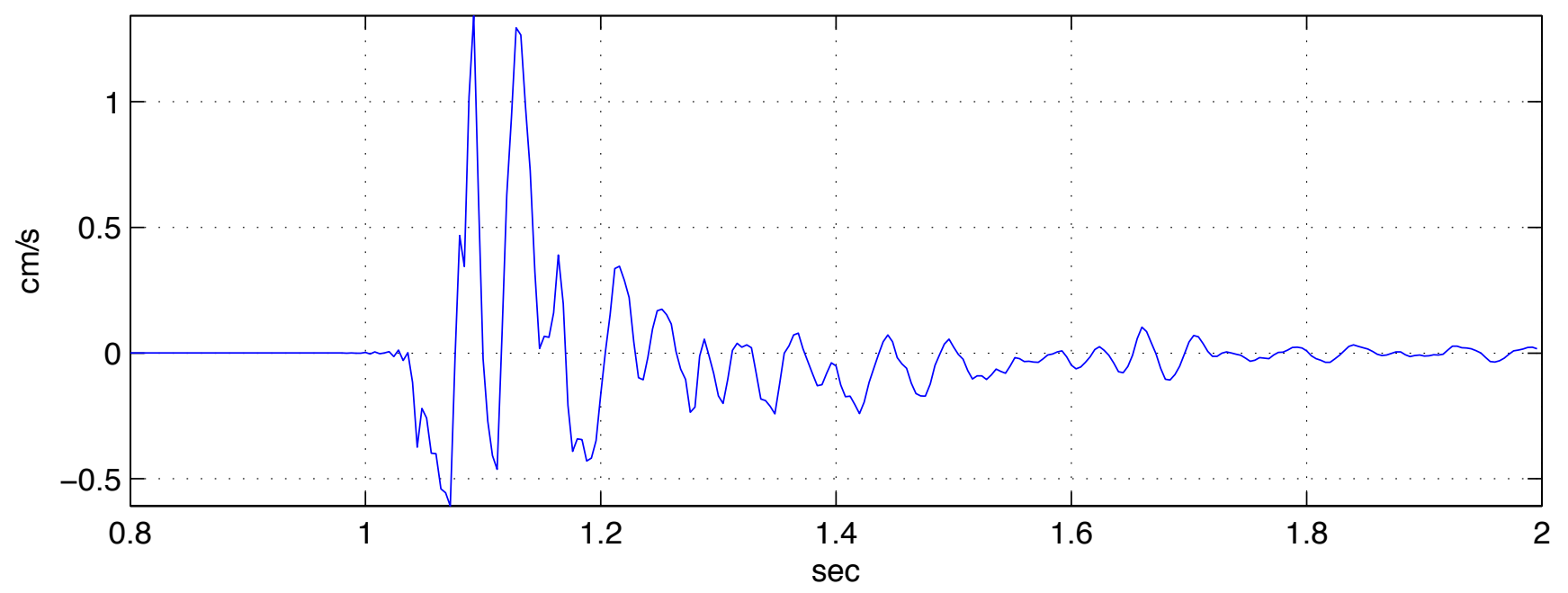

Shot name: sh2-sta102v.sgy Horizontal 2 Vel. $\max$ vel: 0.75079 min vel: $-1.4886 \mathrm{~cm} / \mathrm{s}$

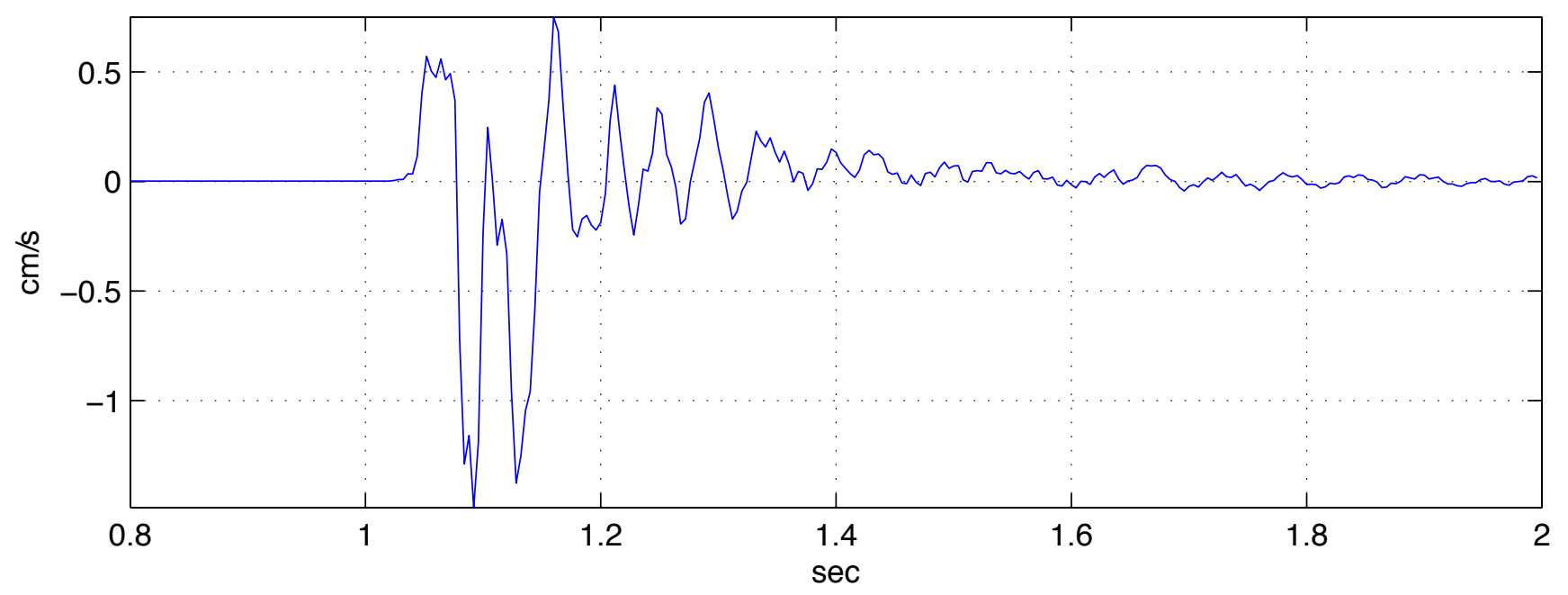


Shot name: sh2-sta103v.sgy Vertical Vel. max vel: $3.8488 \mathrm{~min}$ vel: $-4.8978 \mathrm{~cm} / \mathrm{s}$

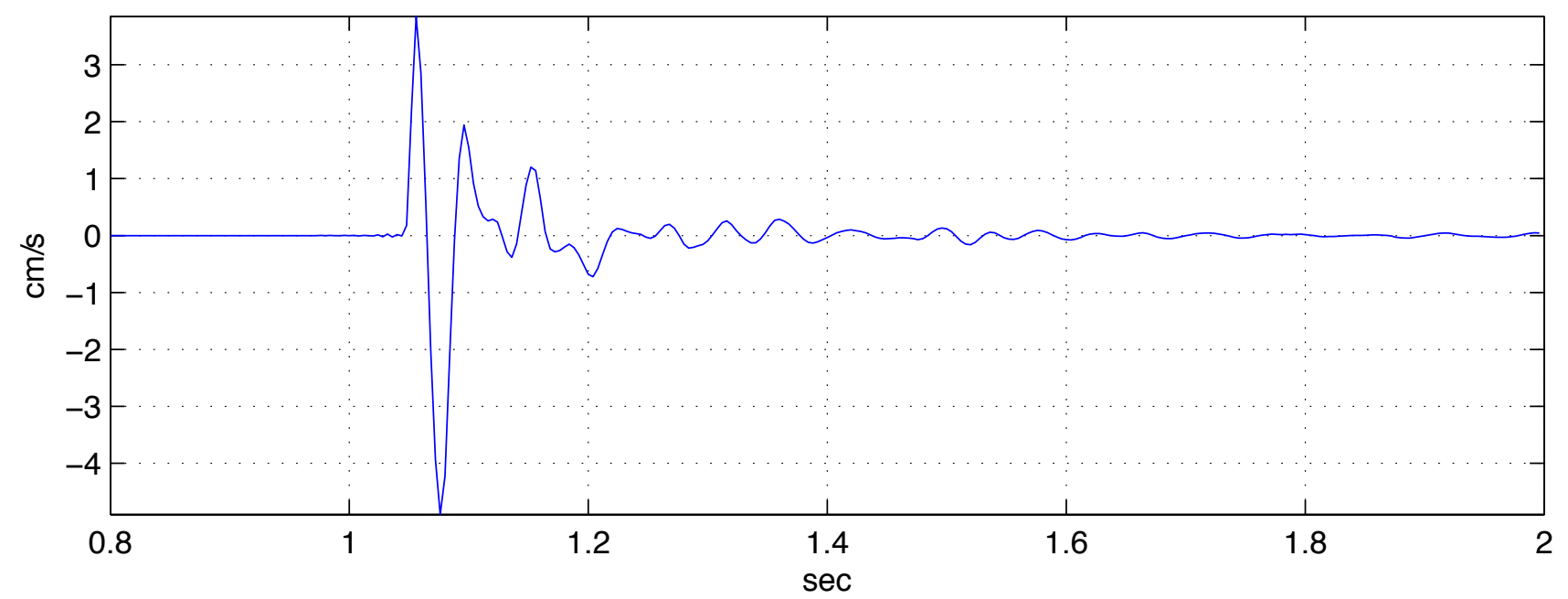

Shot name: sh2-sta103v.sgy Horizontal 1 Vel. max vel: $1.3154 \mathrm{~min}$ vel: $-1.5118 \mathrm{~cm} / \mathrm{s}$

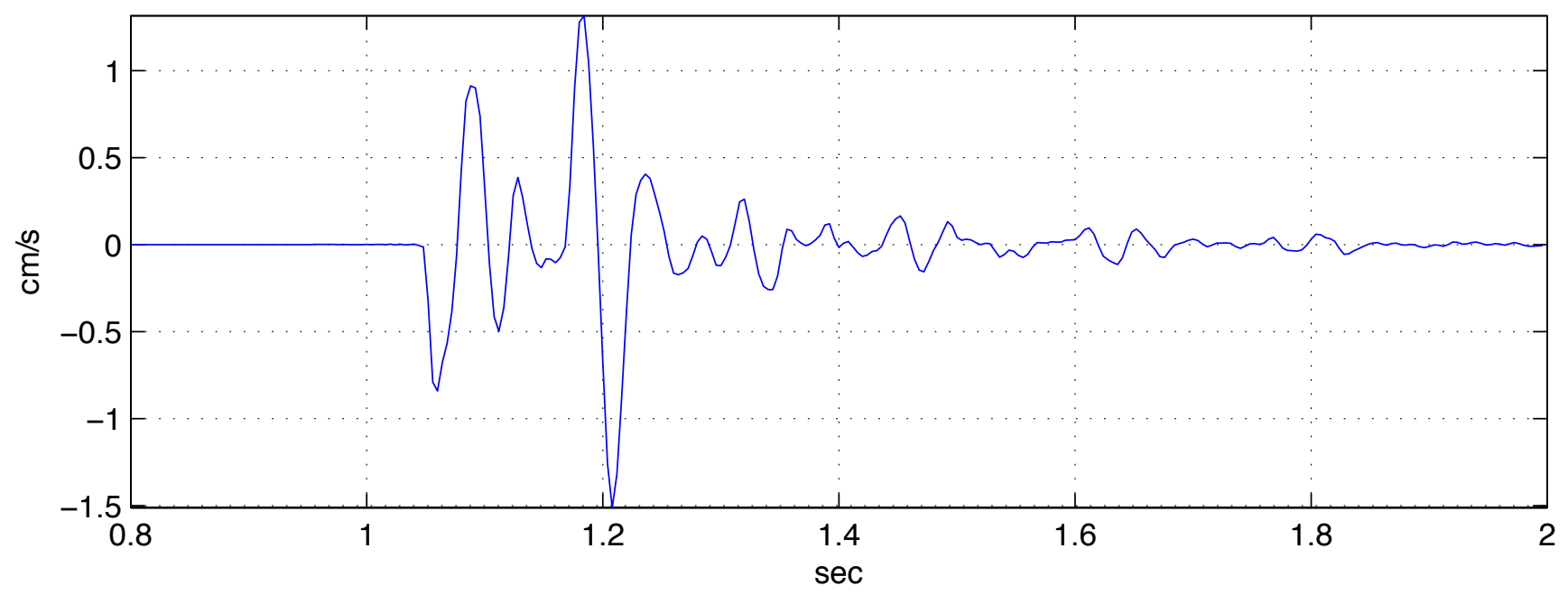

Shot name: sh2-sta103v.sgy Horizontal 2 Vel. max vel: 0.45631 min vel: $-0.27236 \mathrm{~cm} / \mathrm{s}$

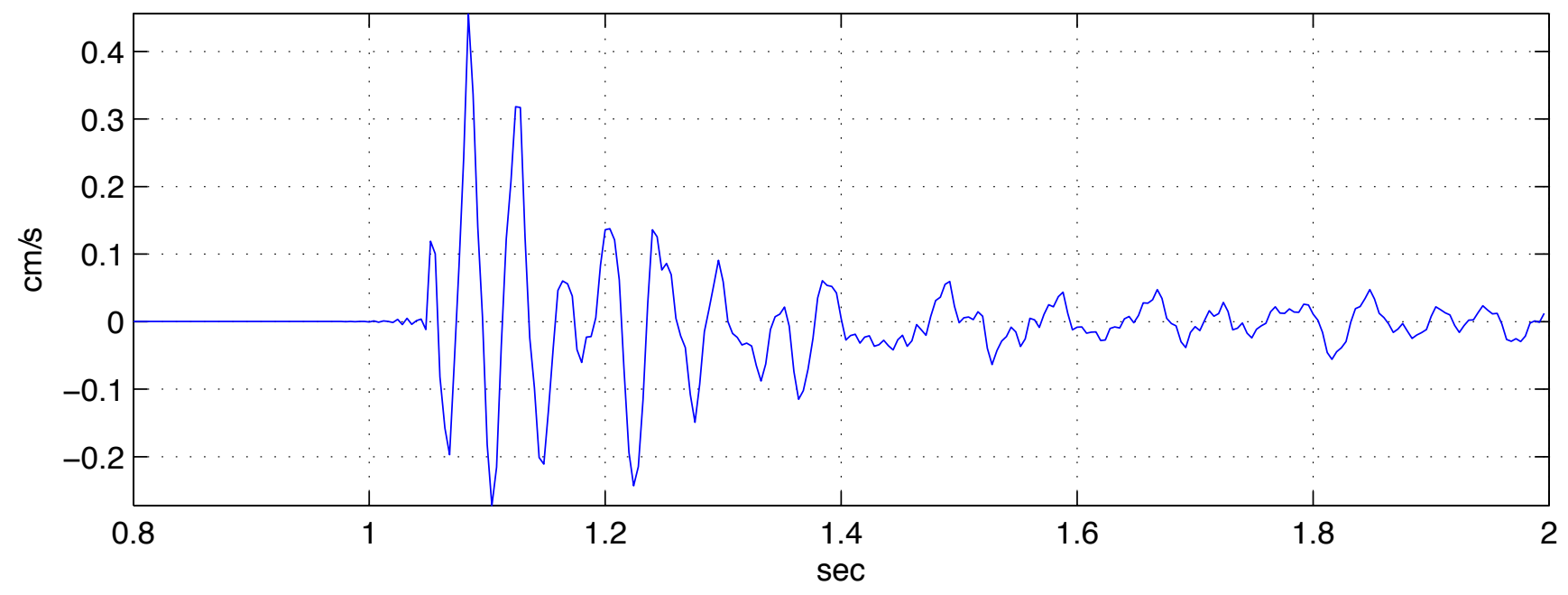




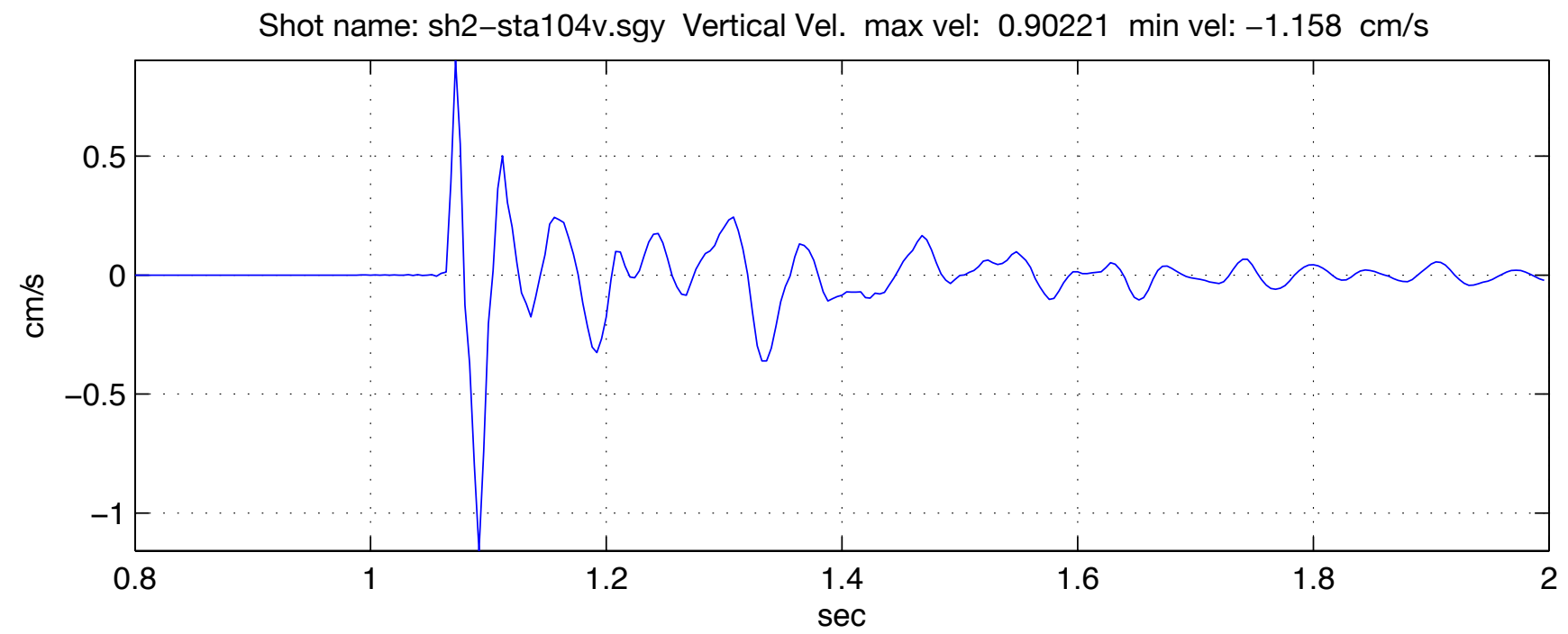

Shot name: sh2-sta104v.sgy Horizontal 1 Vel. max vel: $0.29801 \mathrm{~min}$ vel: $-0.15816 \mathrm{~cm} / \mathrm{s}$

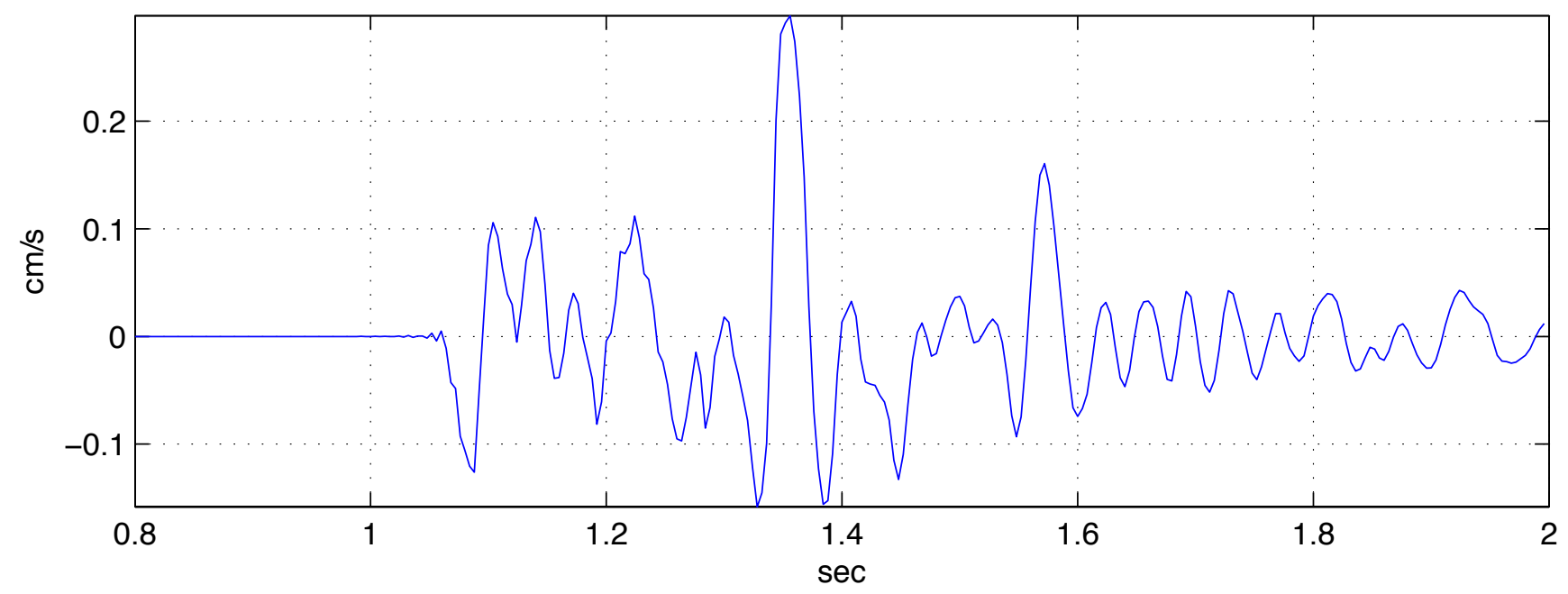

Shot name: sh2-sta104v.sgy Horizontal 2 Vel. max vel: 0.10534 min vel: $-0.13438 \mathrm{~cm} / \mathrm{s}$

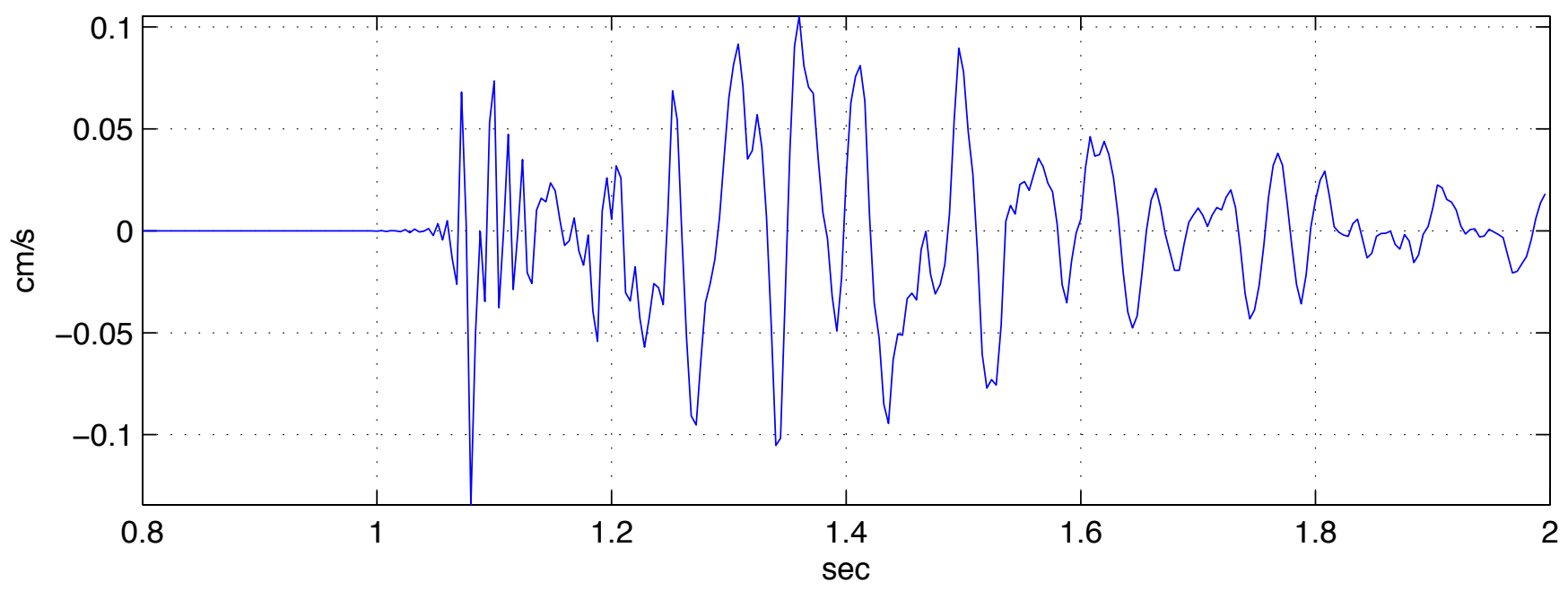




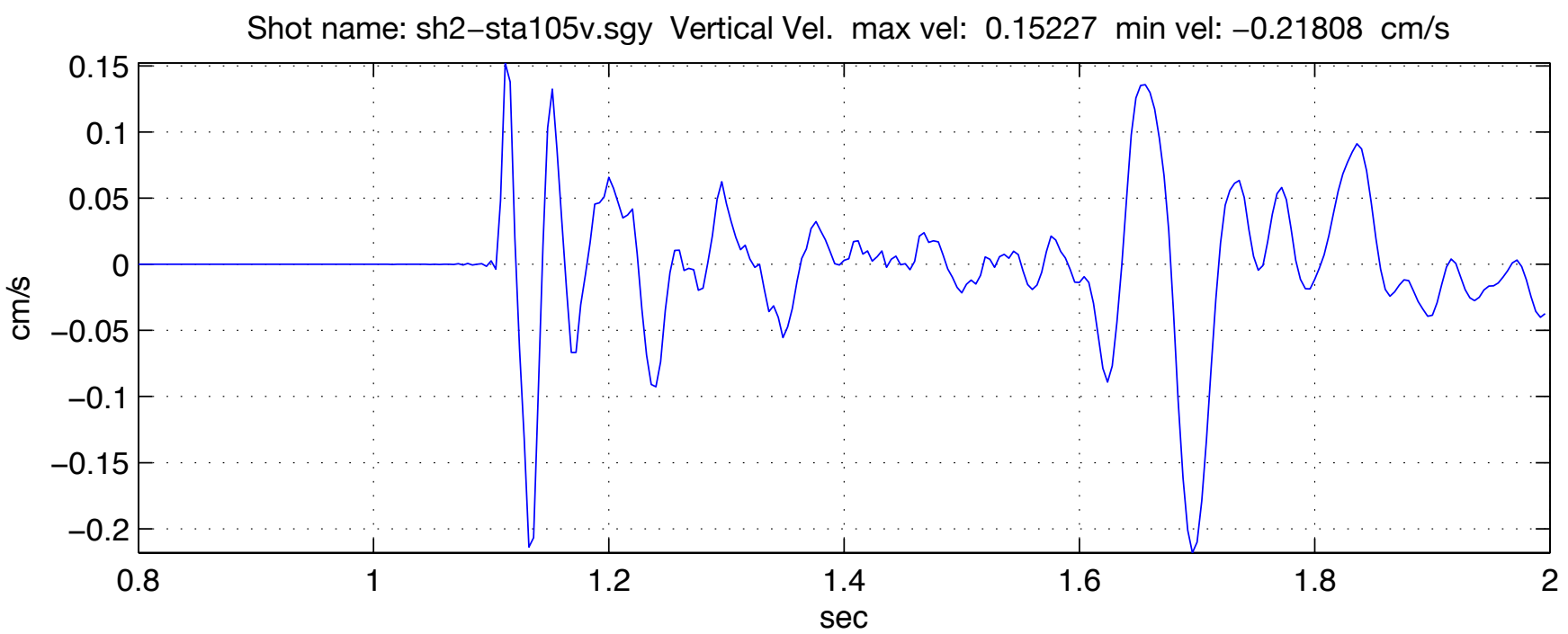

Shot name: sh2-sta105v.sgy Horizontal 1 Vel. max vel: 0.078885 min vel: $-0.10959 \mathrm{~cm} / \mathrm{s}$

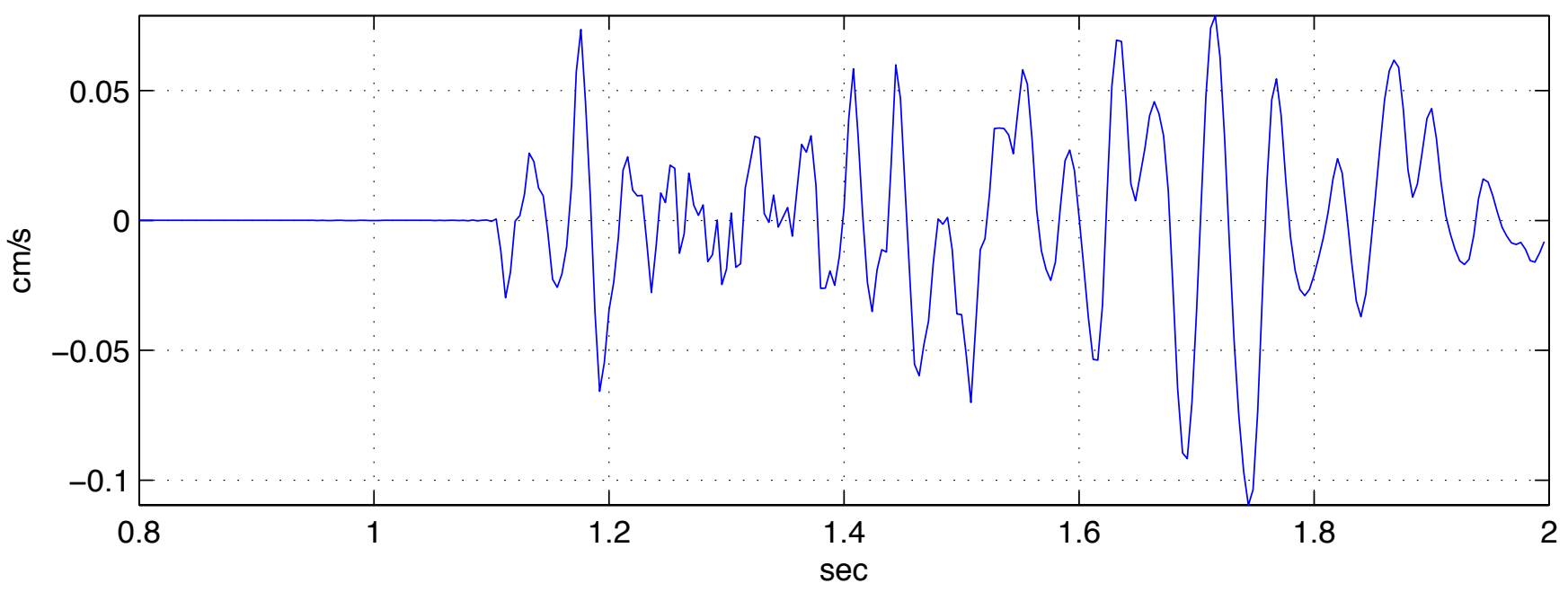

Shot name: sh2-sta105v.sgy Horizontal 2 Vel. max vel: 0.14006 min vel: $-0.11 \mathrm{~cm} / \mathrm{s}$

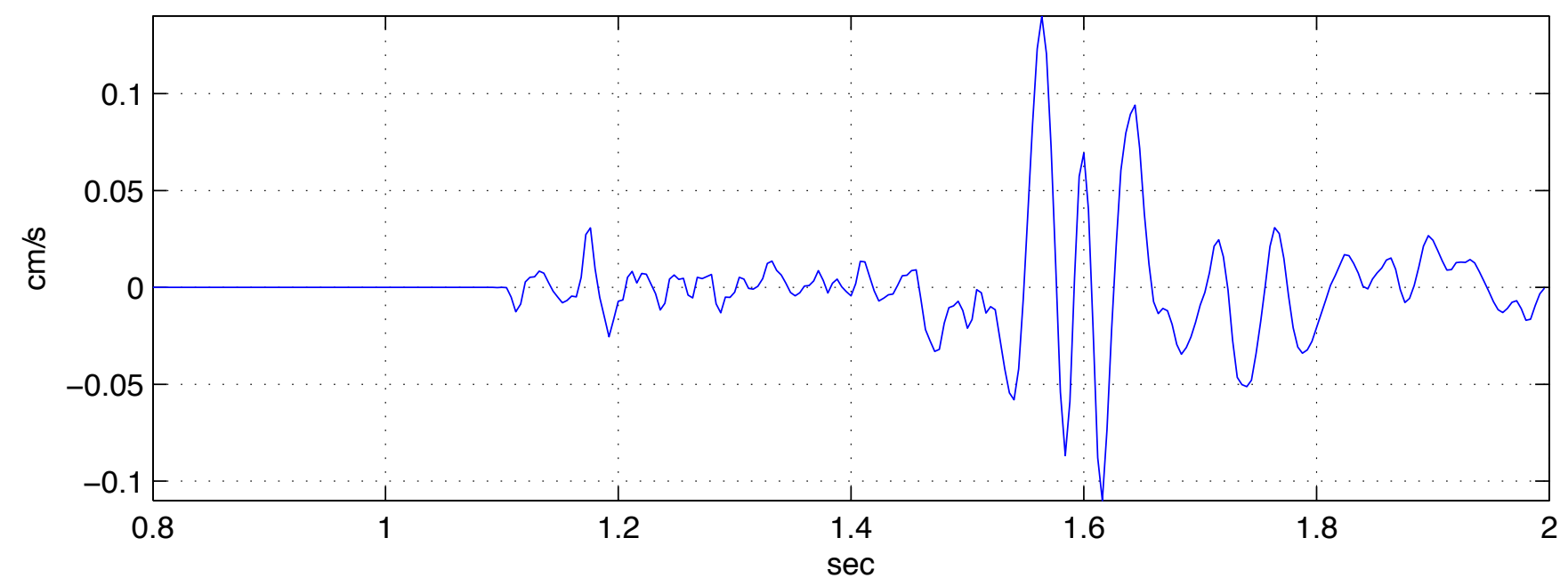


Shot name: sh2-sta106v.sgy Vertical Vel. max vel: $0.09774 \mathrm{~min}$ vel: $-0.083326 \mathrm{~cm} / \mathrm{s}$

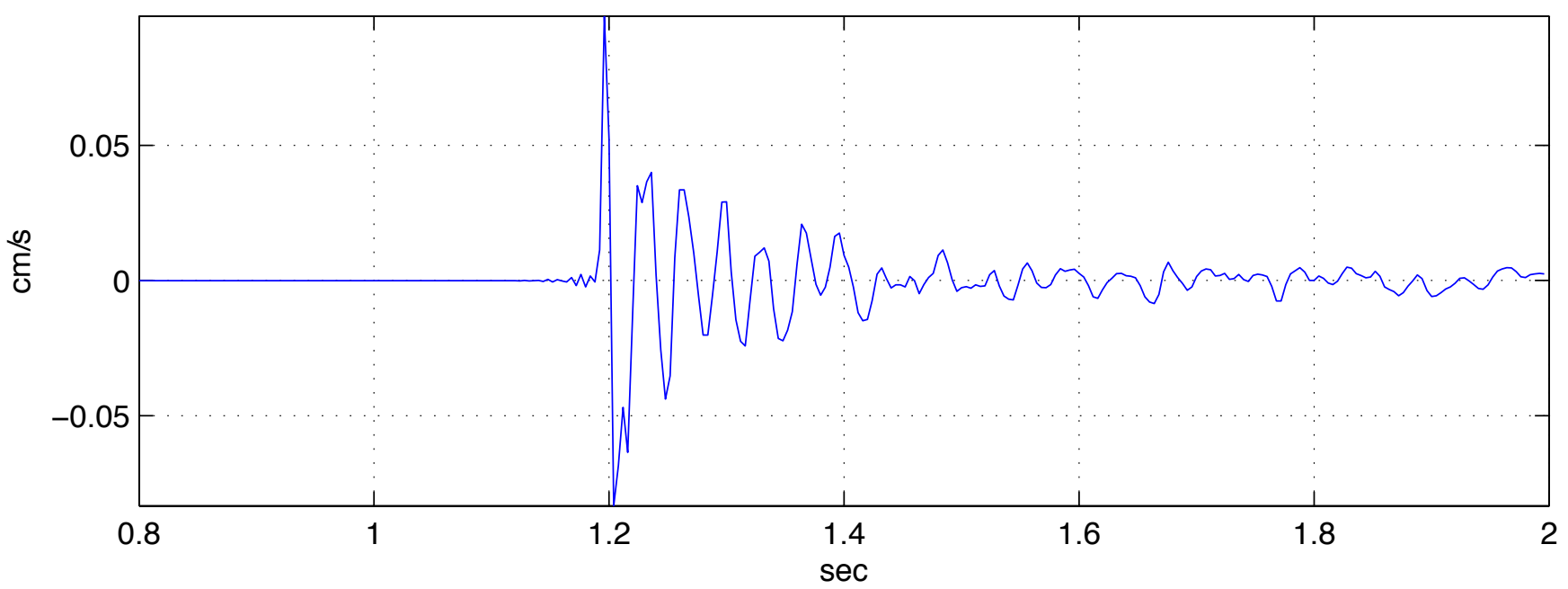

Shot name: sh2-sta106v.sgy Horizontal 1 Vel. max vel: 0.042399 min vel: $-0.042572 \mathrm{~cm} / \mathrm{s}$

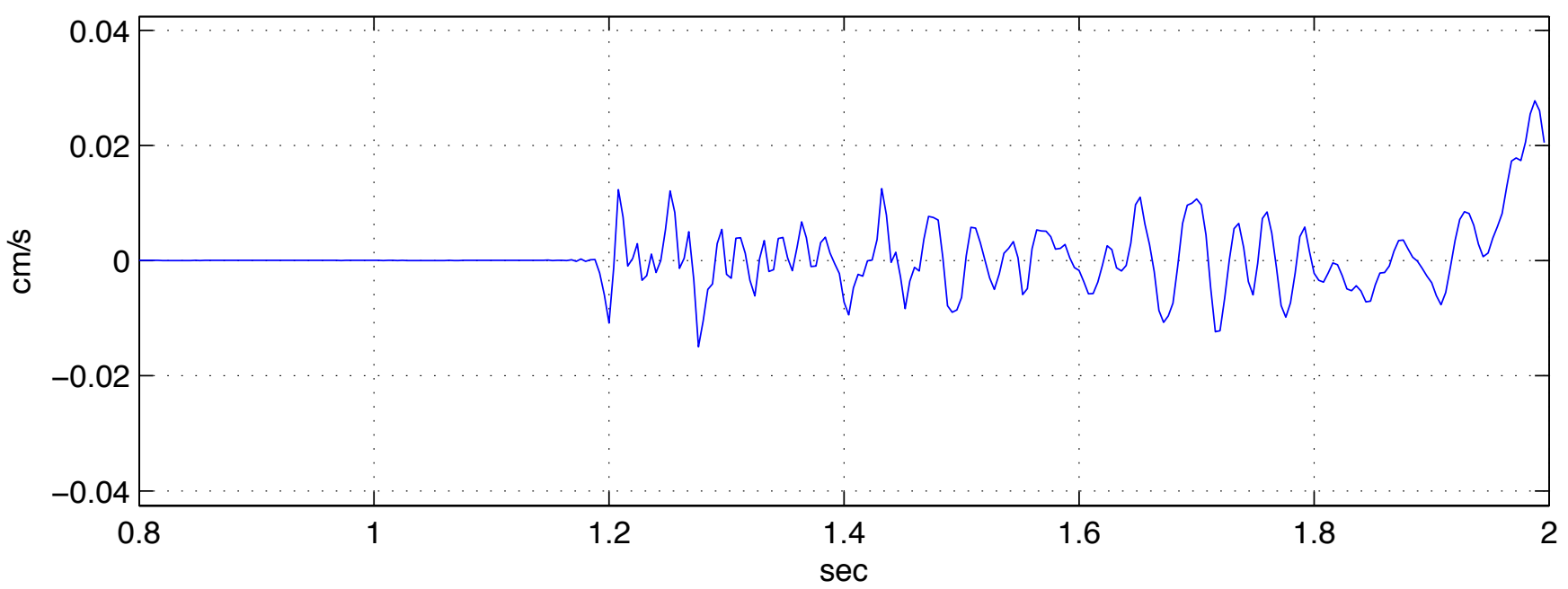

Shot name: sh2-sta106v.sgy Horizontal 2 Vel. max vel: 0.034291 min vel: $-0.026163 \mathrm{~cm} / \mathrm{s}$

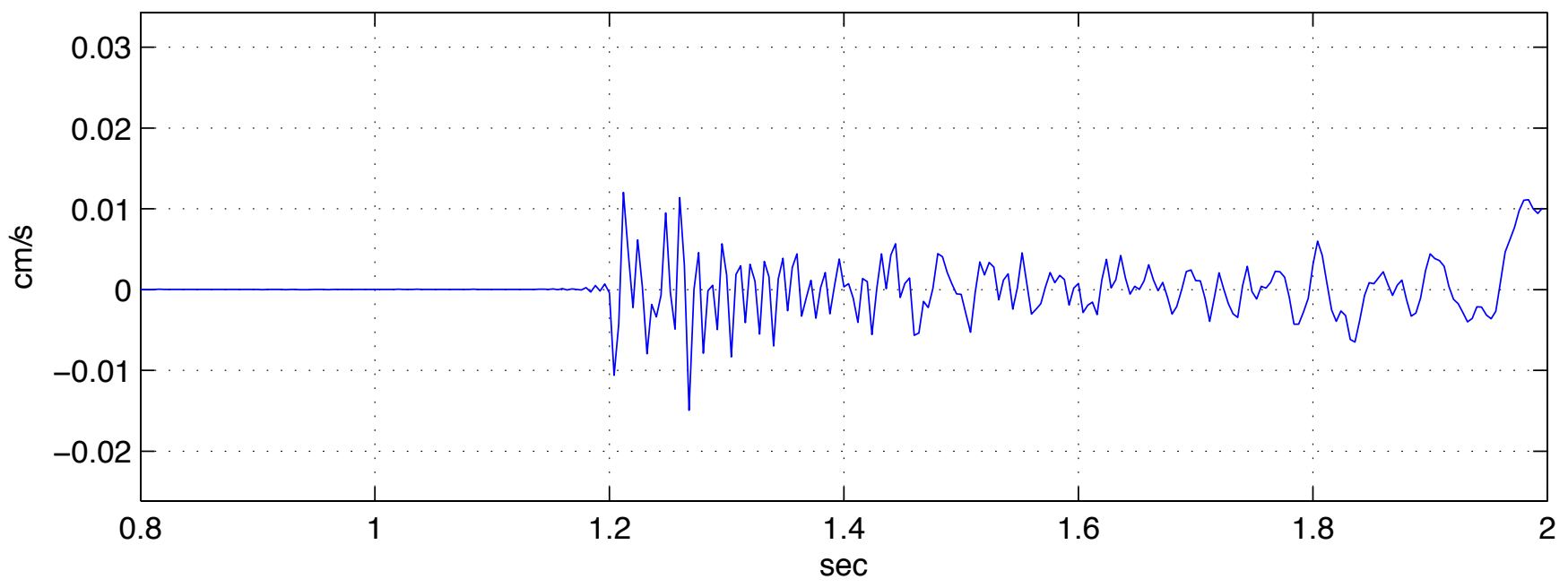


Shot name: sh3-sta101v.sgy Vertical Vel. max vel: $0.54625 \mathrm{~min}$ vel: $-0.8544 \mathrm{~cm} / \mathrm{s}$

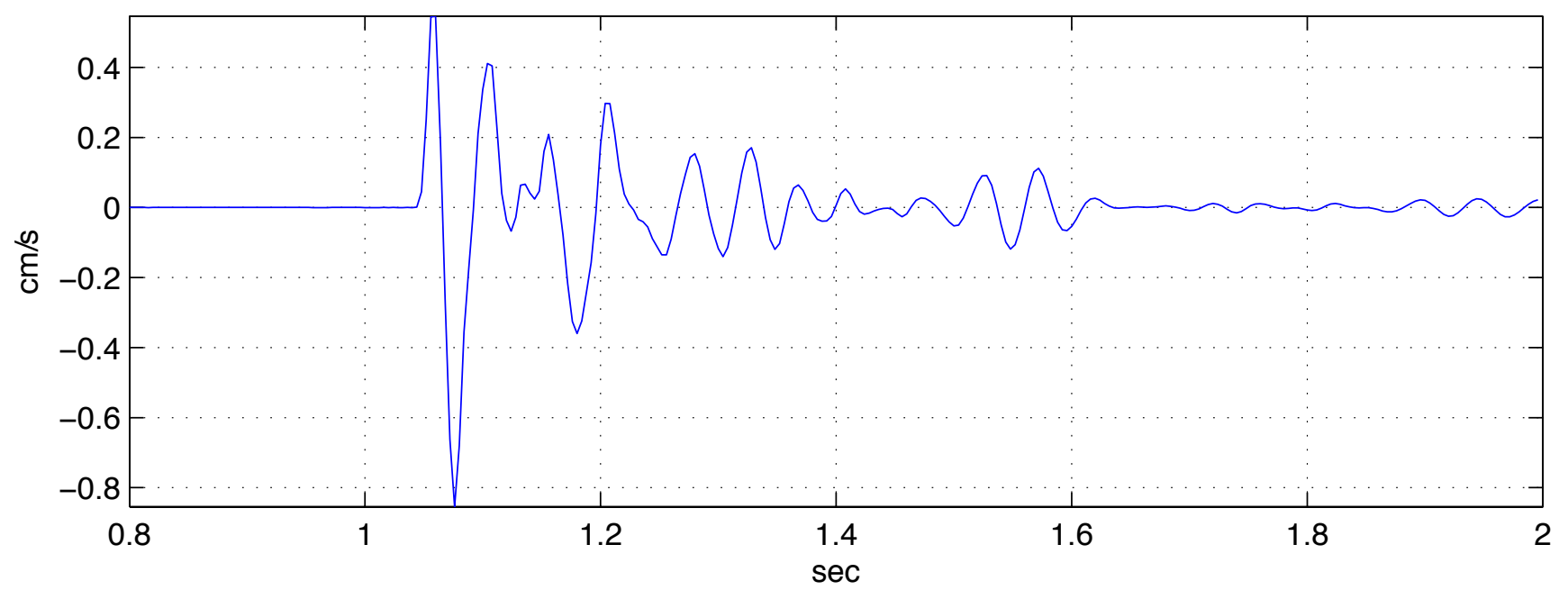

Shot name: sh3-sta101v.sgy Horizontal 1 Vel. max vel: 0.48289 min vel: $-0.55146 \mathrm{~cm} / \mathrm{s}$

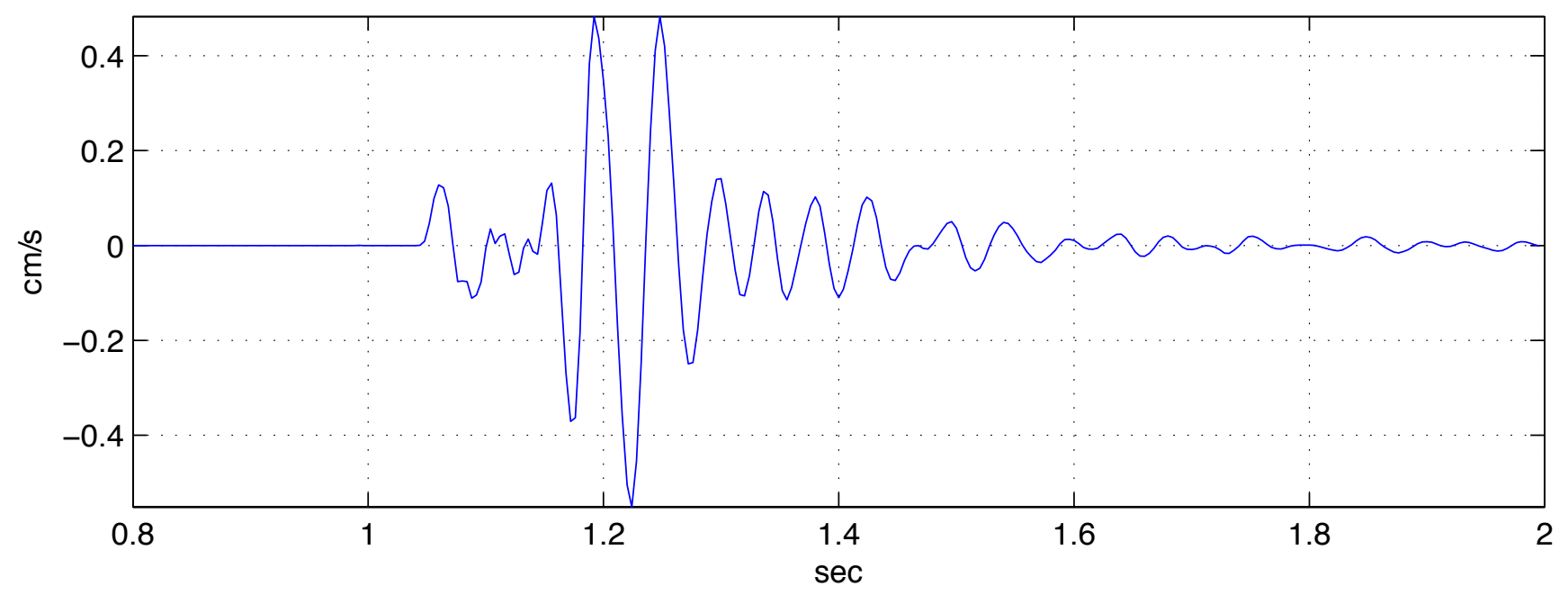

Shot name: sh3-sta101v.sgy Horizontal 2 Vel. max vel: 0.34377 min vel: $-0.35378 \mathrm{~cm} / \mathrm{s}$

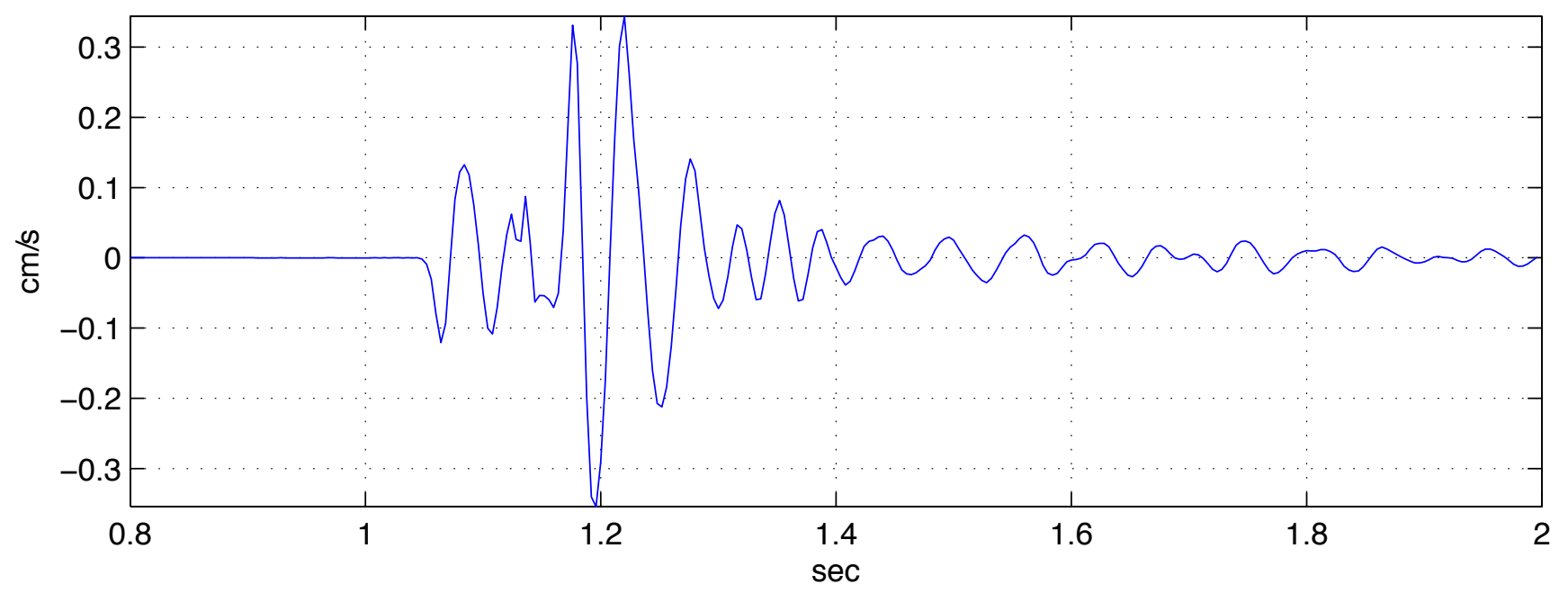


Shot name: sh3-sta102v.sgy Vertical Vel. max vel: 1.4048 min vel: $-1.6745 \mathrm{~cm} / \mathrm{s}$

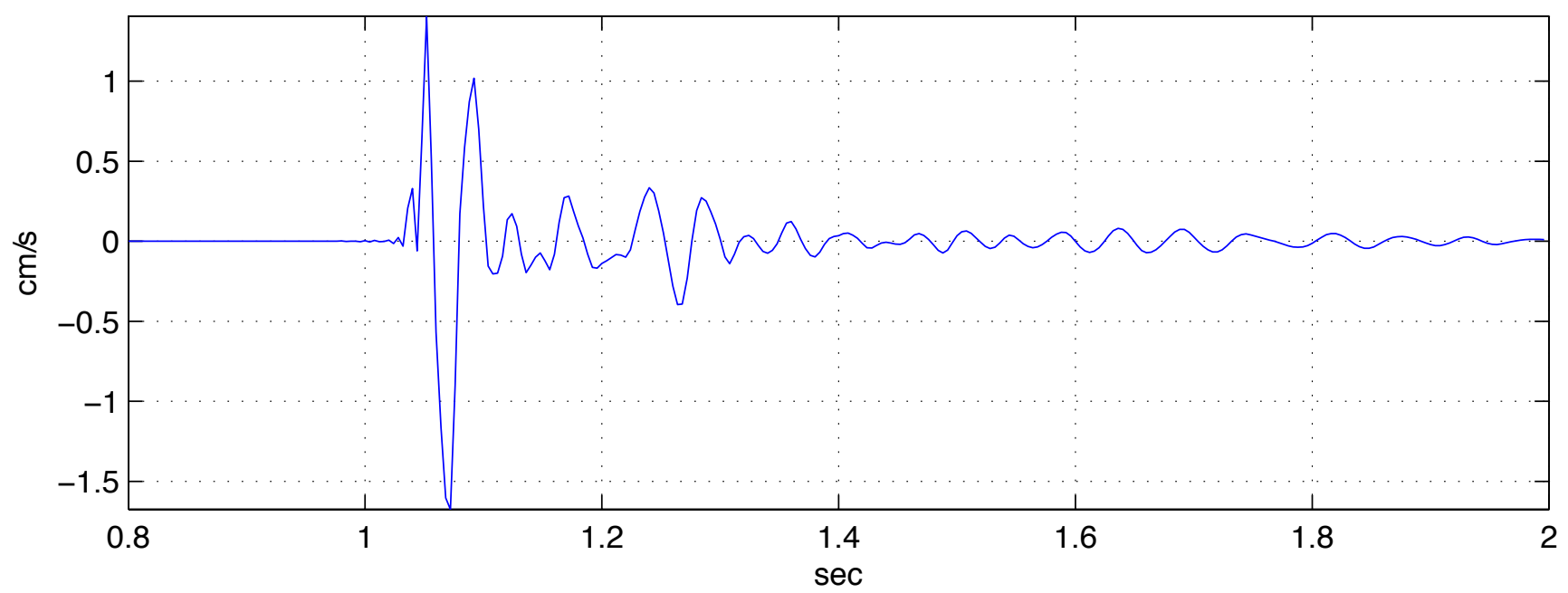

Shot name: sh3-sta102v.sgy Horizontal 1 Vel. max vel: 0.35454 min vel: $-0.2308 \mathrm{~cm} / \mathrm{s}$

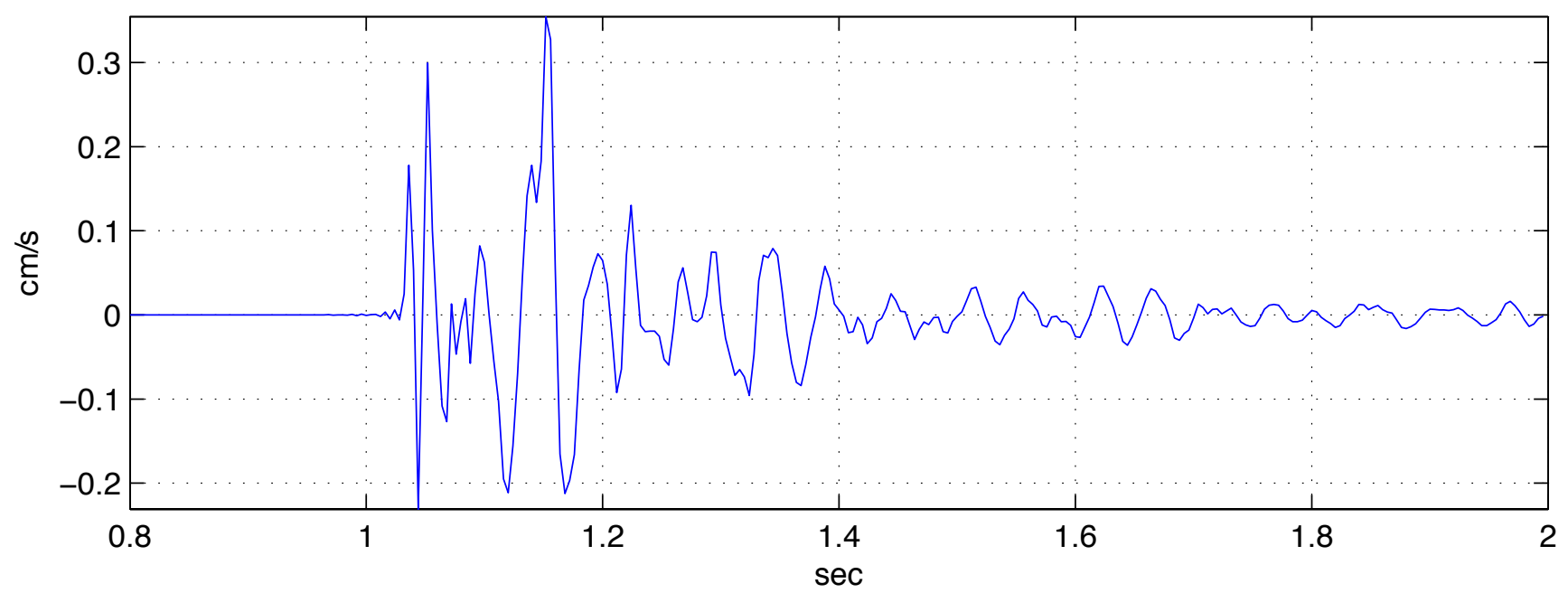

Shot name: sh3-sta102v.sgy Horizontal 2 Vel. max vel: 0.29931 min vel: $-0.20602 \mathrm{~cm} / \mathrm{s}$

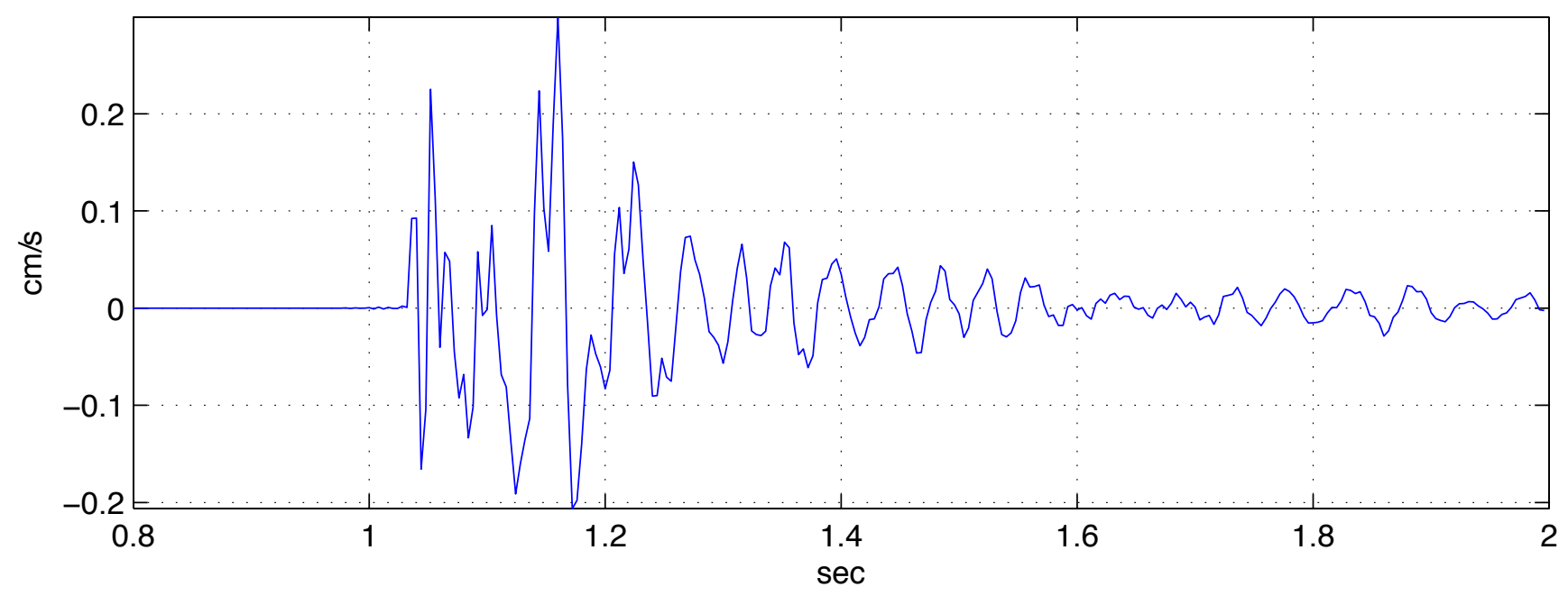


Shot name: sh3-sta103v.sgy Vertical Vel. max vel: $1.7516 \mathrm{~min}$ vel: $-1.8274 \mathrm{~cm} / \mathrm{s}$

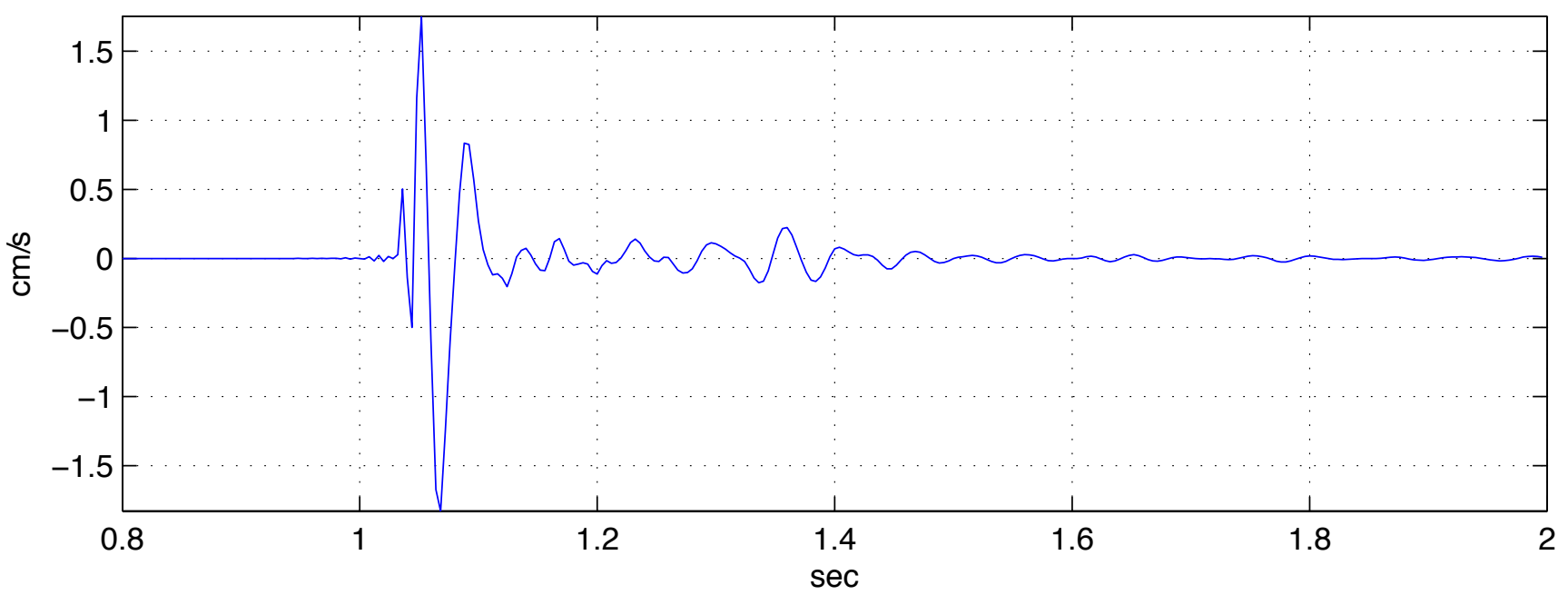

Shot name: sh3-sta103v.sgy Horizontal 1 Vel. max vel: 0.74758 min vel: $-1.0184 \mathrm{~cm} / \mathrm{s}$

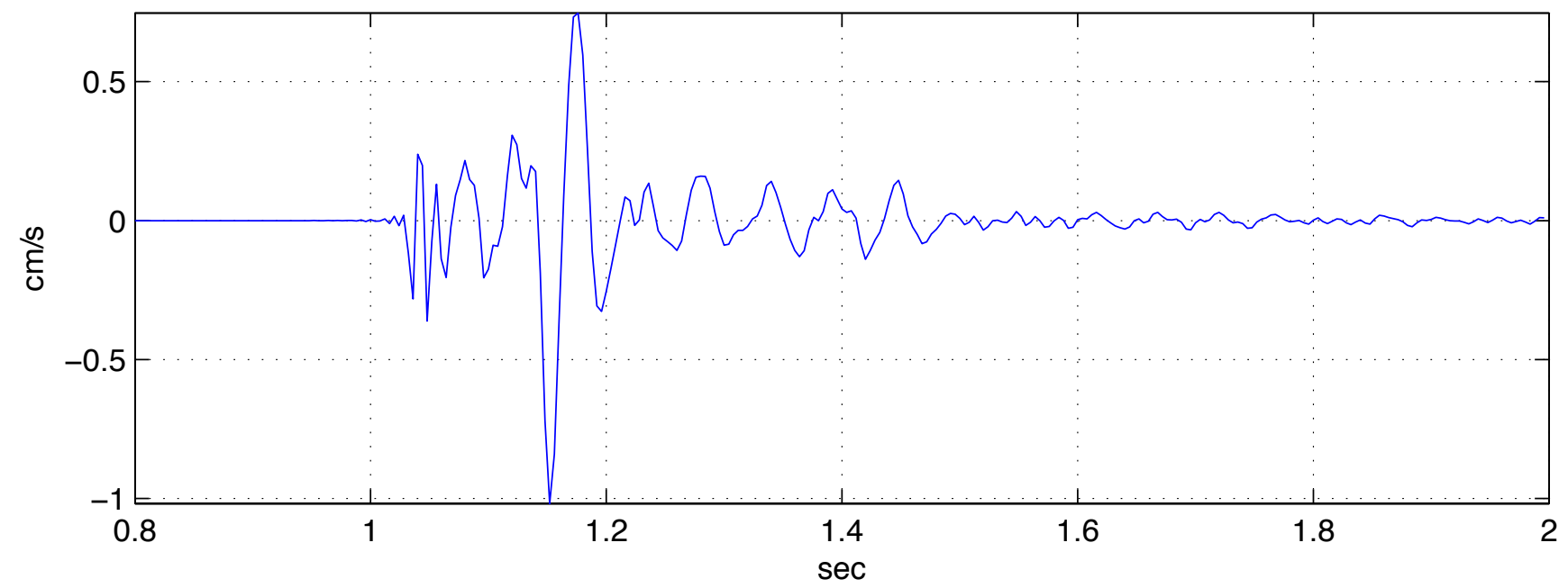

Shot name: sh3-sta103v.sgy Horizontal 2 Vel. max vel: $0.2194 \mathrm{~min}$ vel: $-0.18357 \mathrm{~cm} / \mathrm{s}$

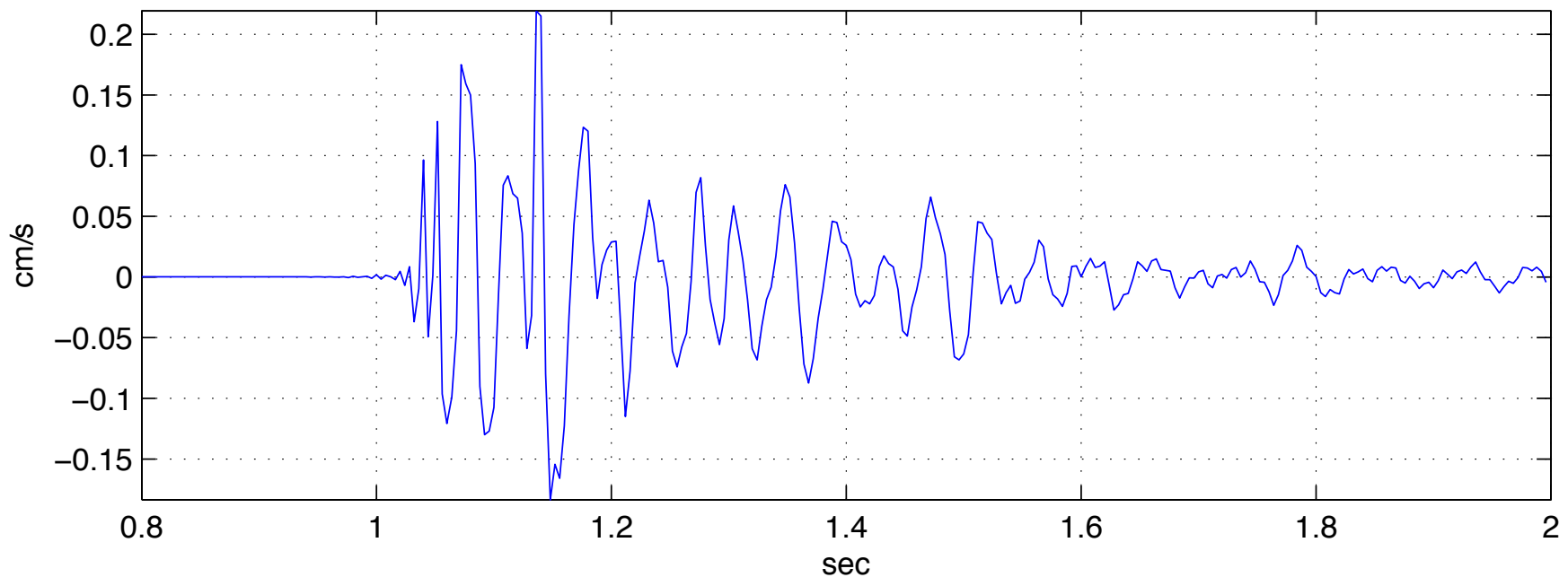




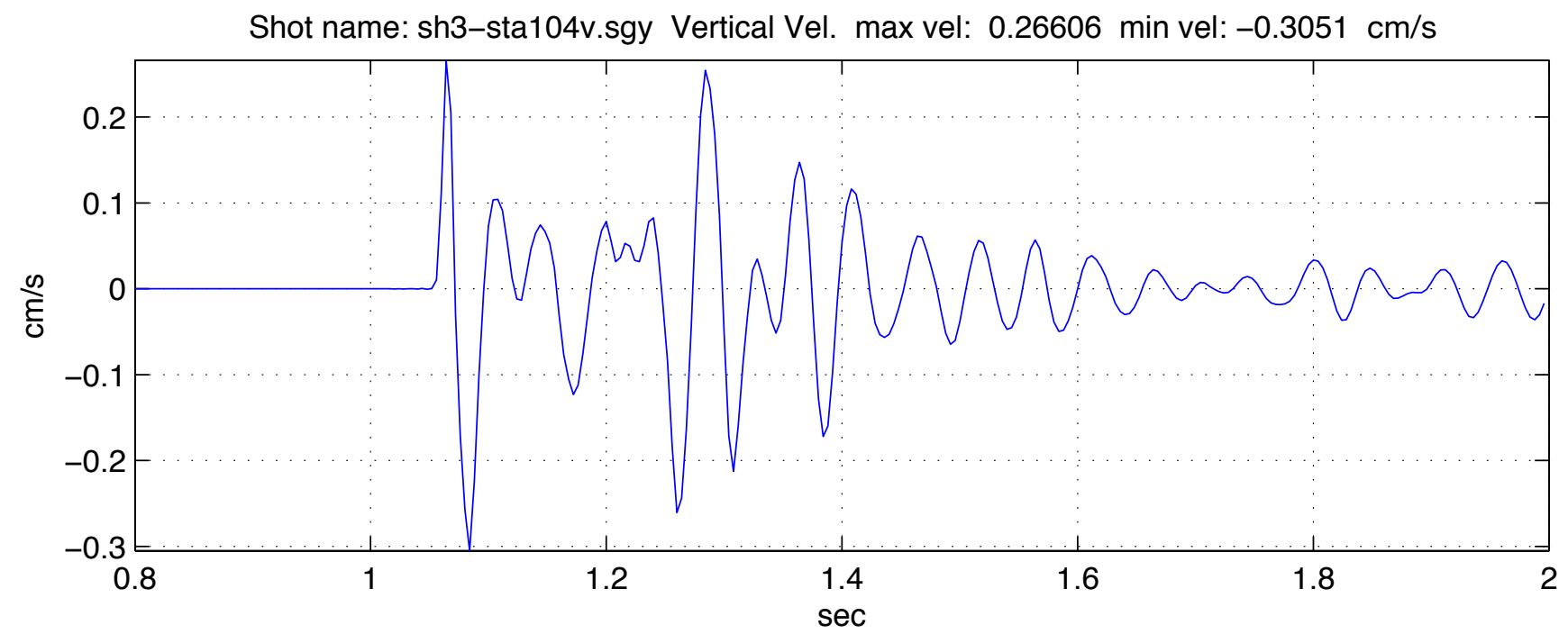

Shot name: sh3-sta104v.sgy Horizontal 1 Vel. max vel: 0.56295 min vel: $-0.47692 \mathrm{~cm} / \mathrm{s}$

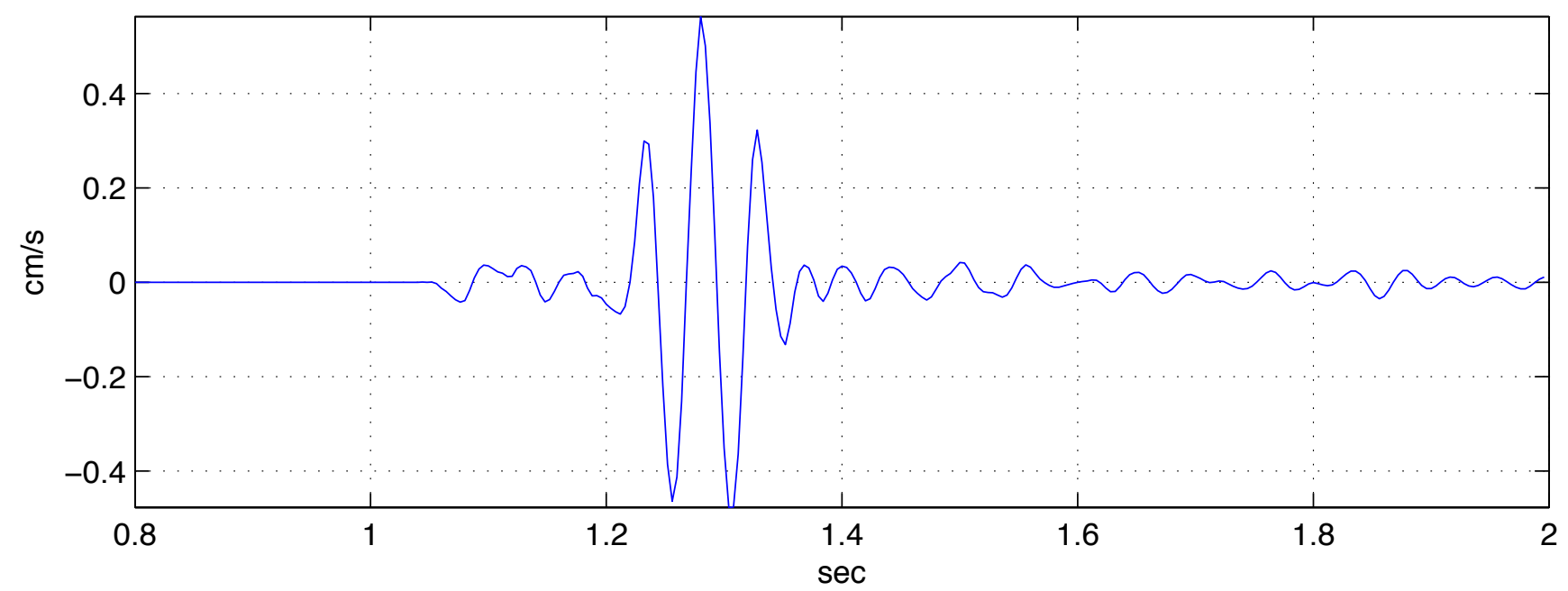

Shot name: sh3-sta104v.sgy Horizontal 2 Vel. max vel: 0.17415 min vel: $-0.18828 \mathrm{~cm} / \mathrm{s}$

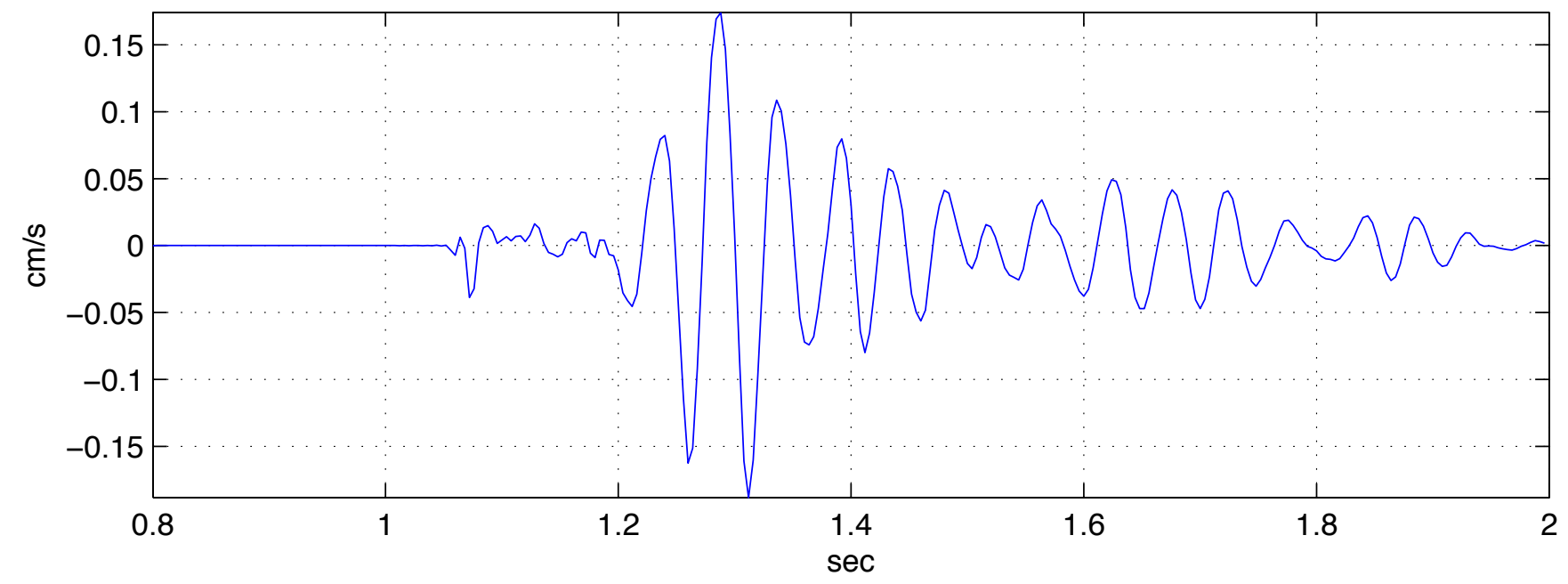


Shot name: sh3-sta105v.sgy Vertical Vel. max vel: $0.095994 \mathrm{~min}$ vel: $-0.09395 \mathrm{~cm} / \mathrm{s}$

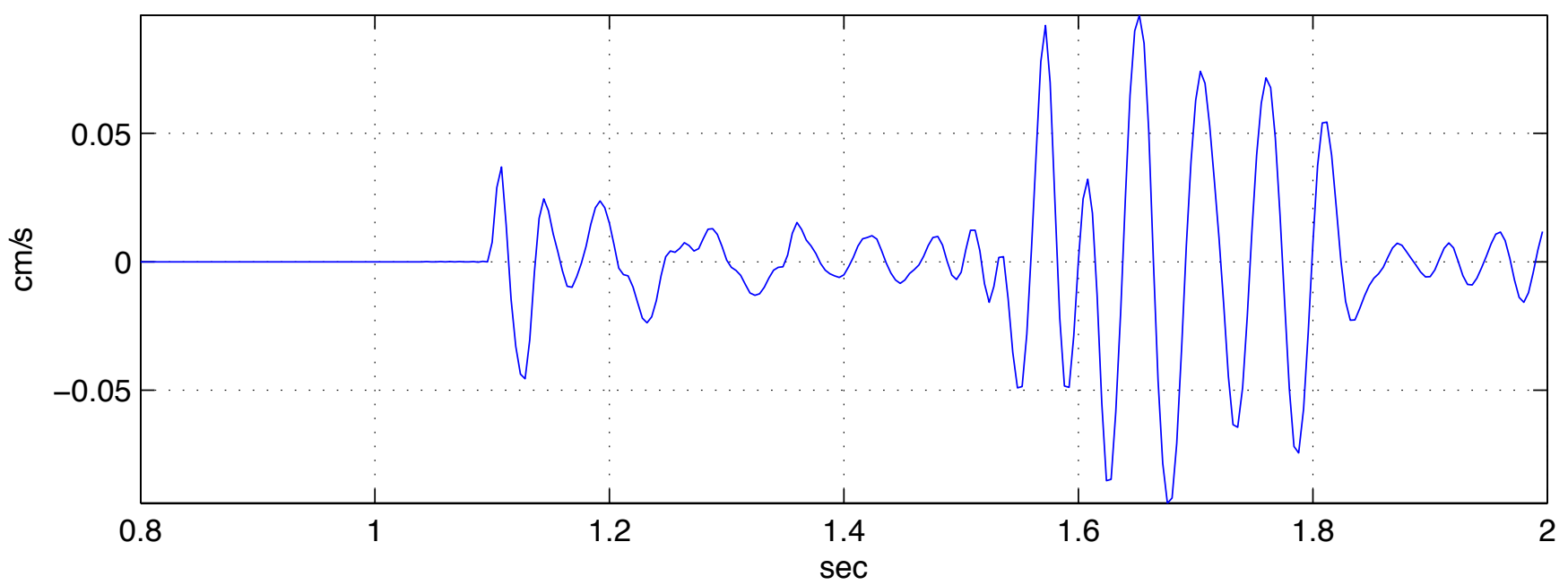

Shot name: sh3-sta105v.sgy Horizontal 1 Vel. max vel: 0.061303 min vel: $-0.066998 \mathrm{~cm} / \mathrm{s}$

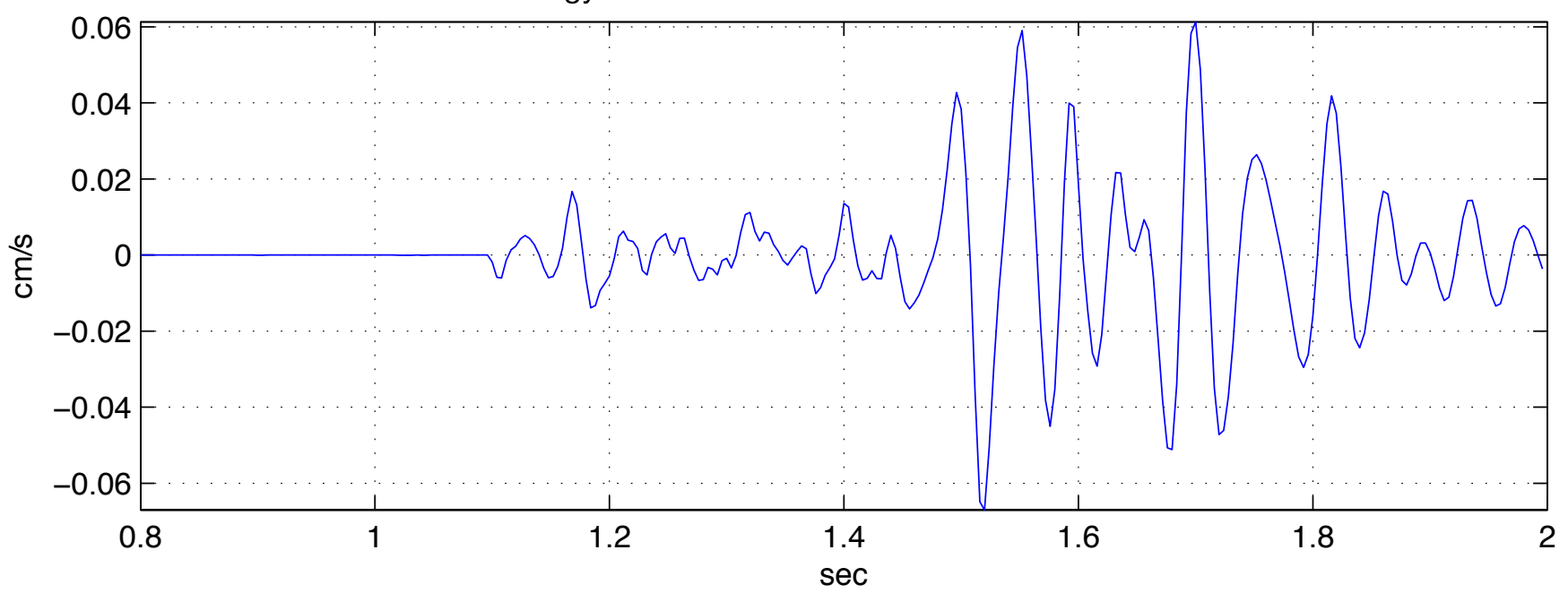

Shot name: sh3-sta105v.sgy Horizontal 2 Vel. max vel: 0.082067 min vel: $-0.074 \mathrm{~cm} / \mathrm{s}$

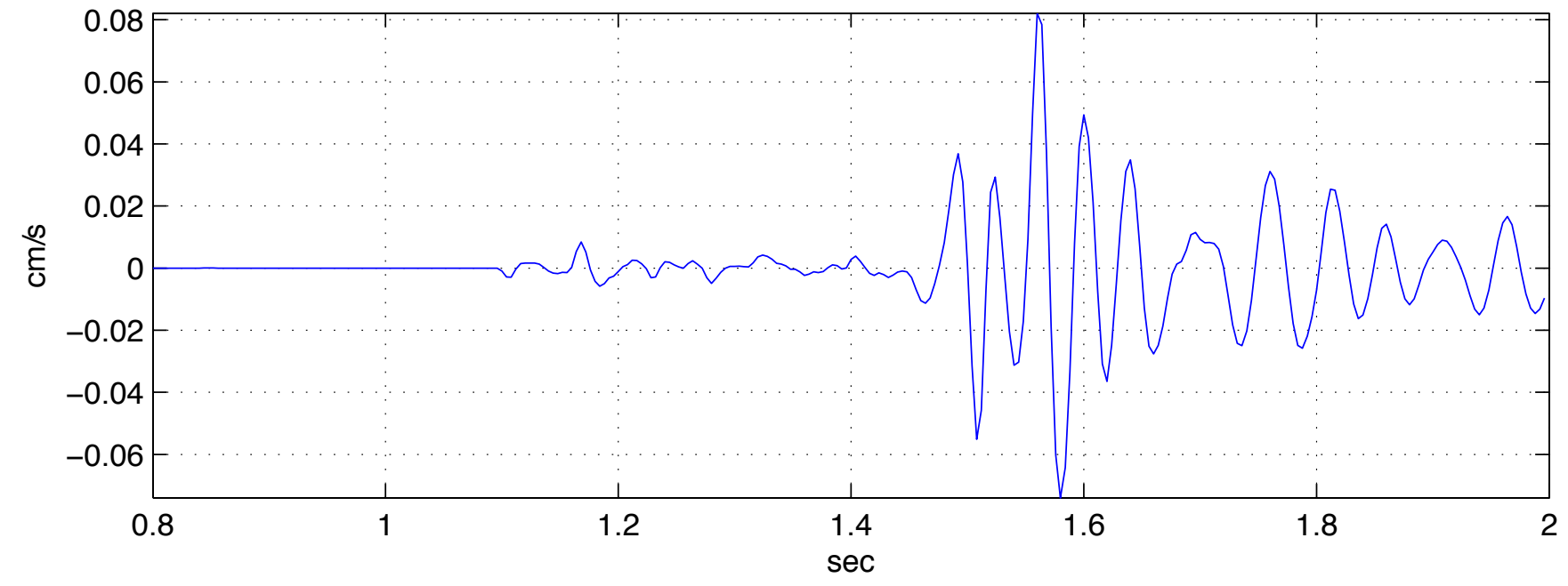




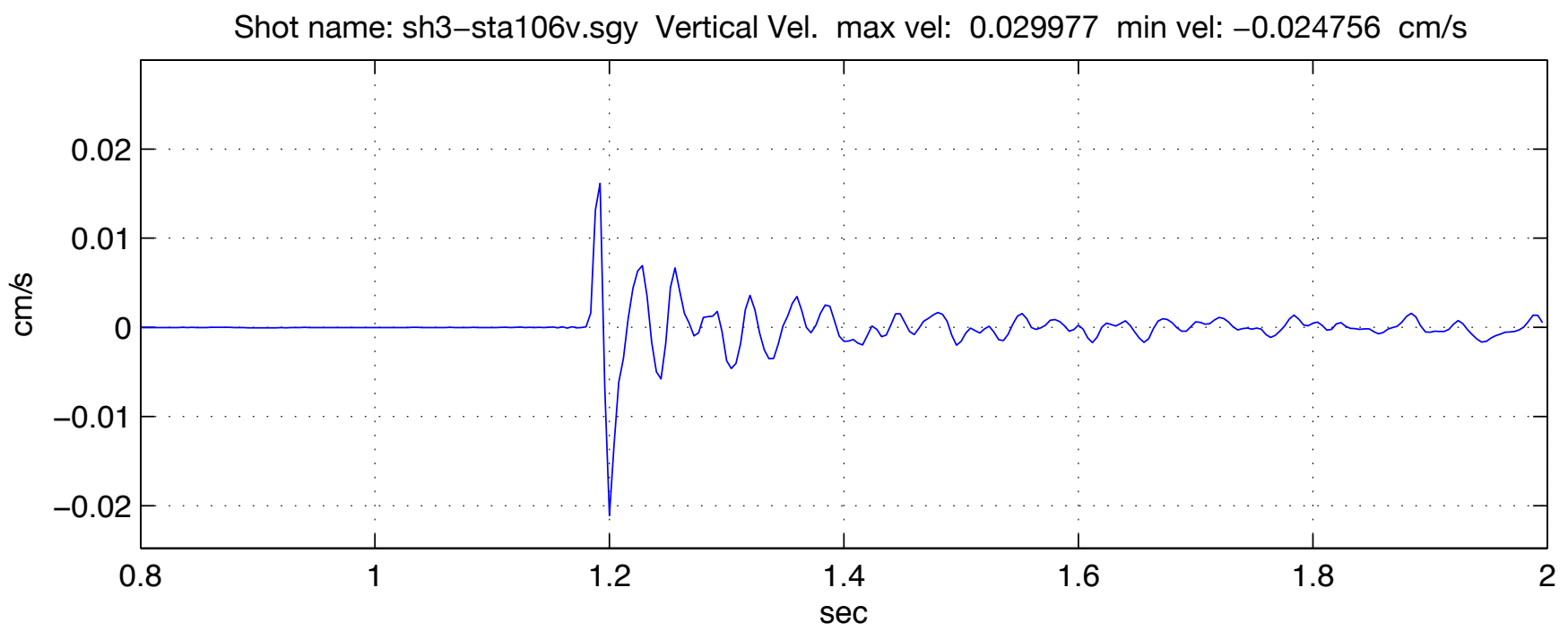

Shot name: sh3-sta106v.sgy Horizontal 1 Vel. max vel: $0.036757 \mathrm{~min}$ vel: $-0.03738 \mathrm{~cm} / \mathrm{s}$
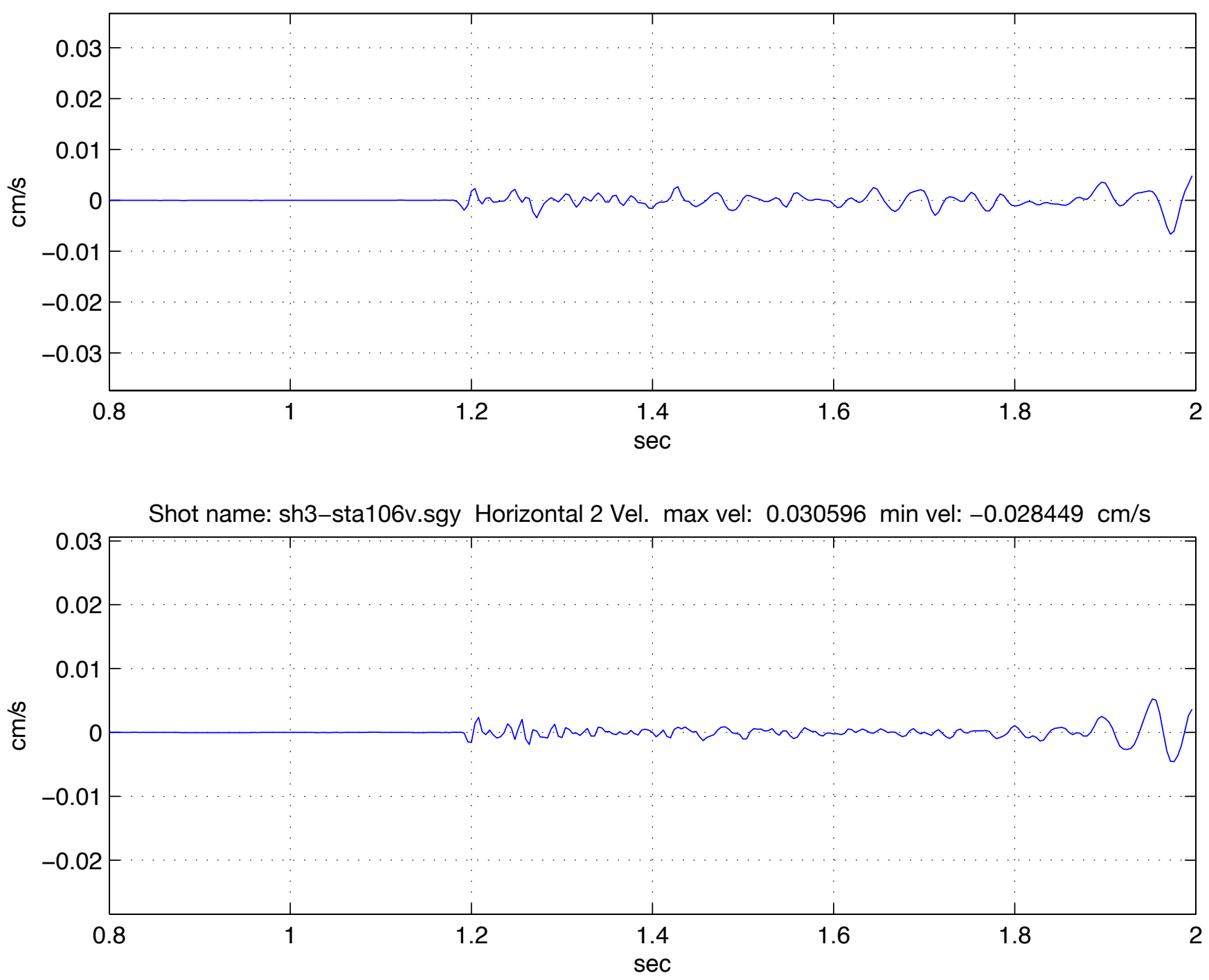
Appendix 4. Near Source High Resolution Receiver Velocity Plots

[Seismic traces are from the cabled array. Zero time is the moment of detonation of the shot.] 


\section{CABLE ARRAY}

trace equalization

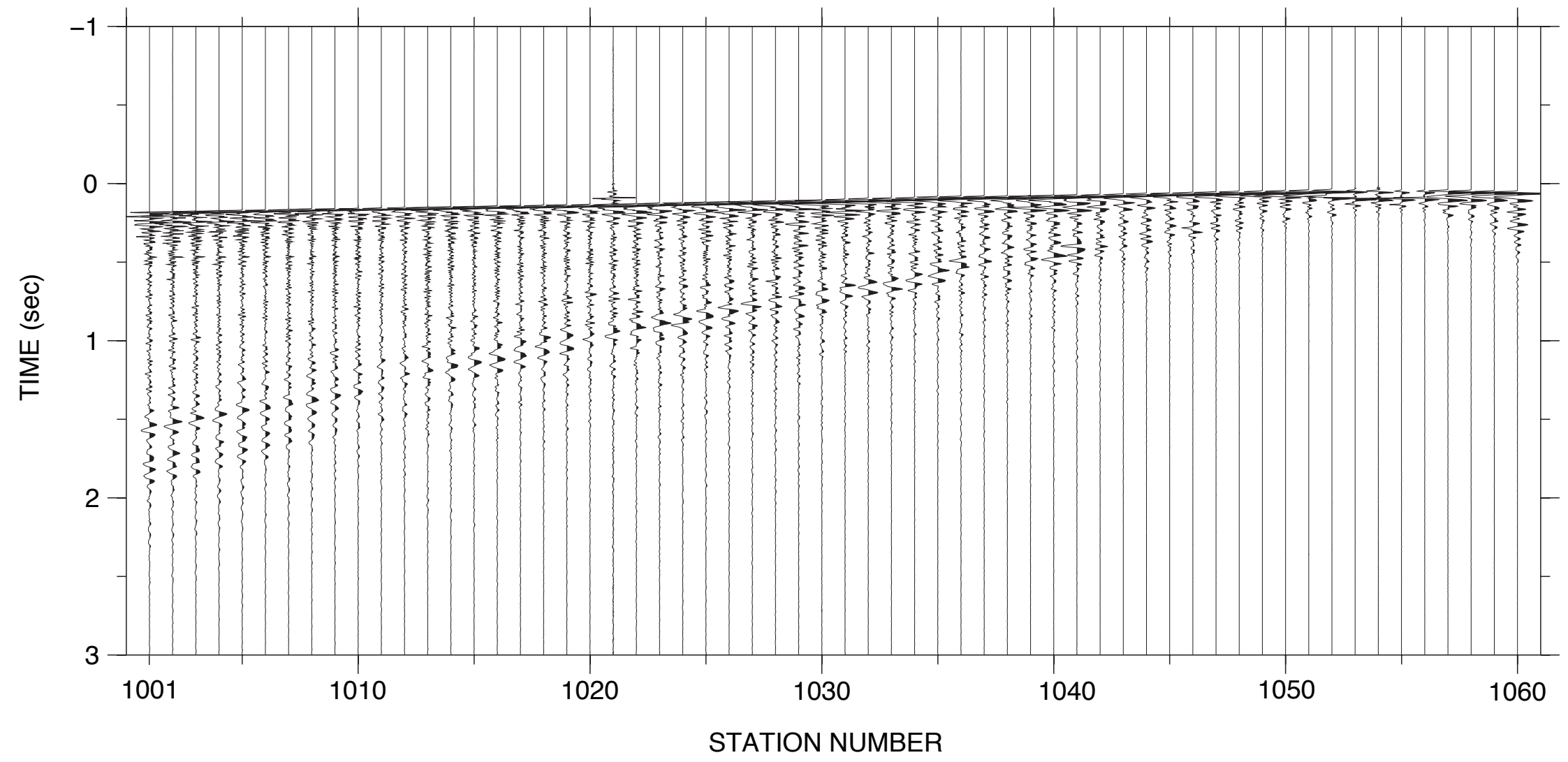




\section{CABLE ARRAY}

trace equalization

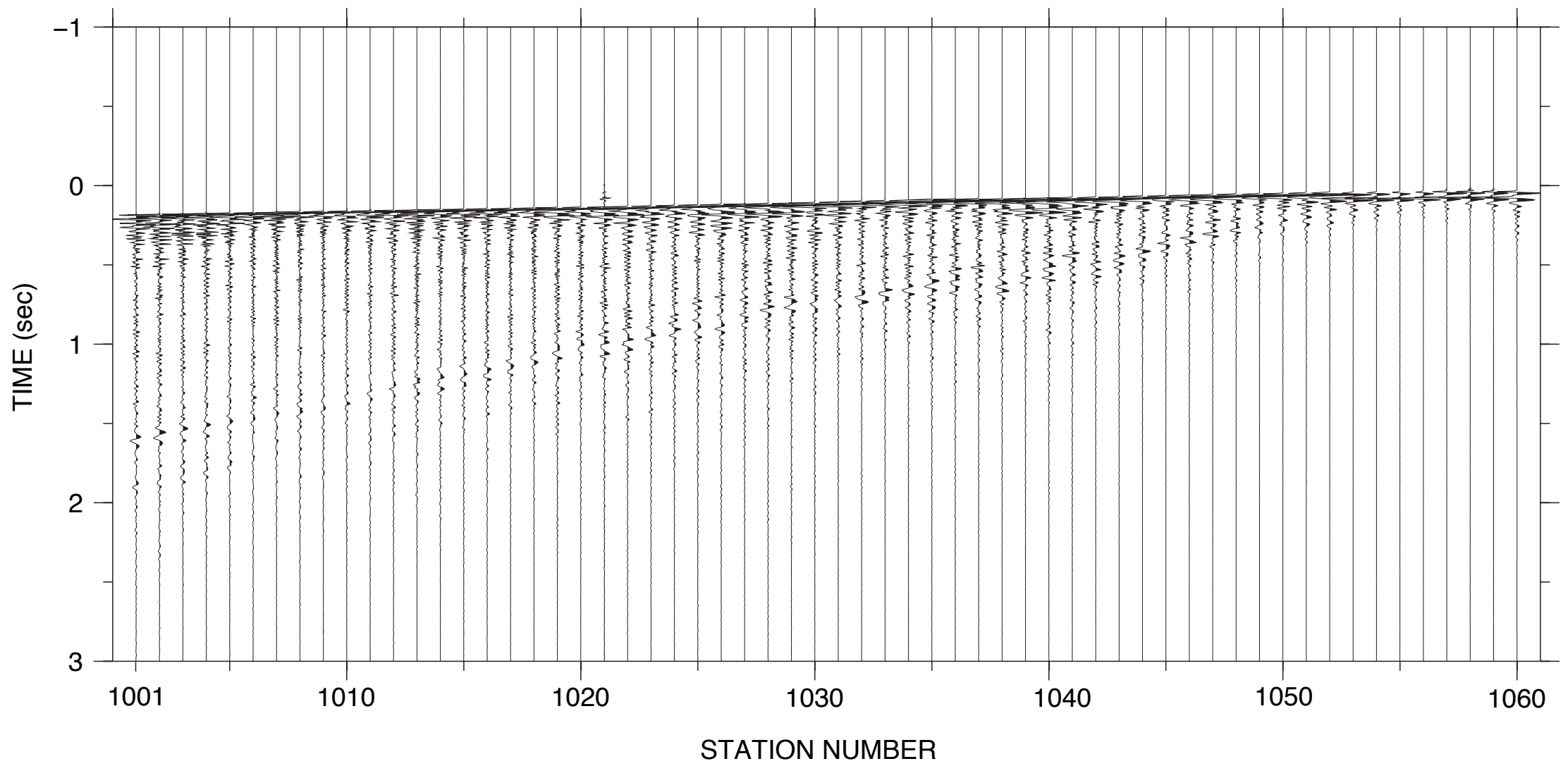




\section{CABLE ARRAY}

trace equalization

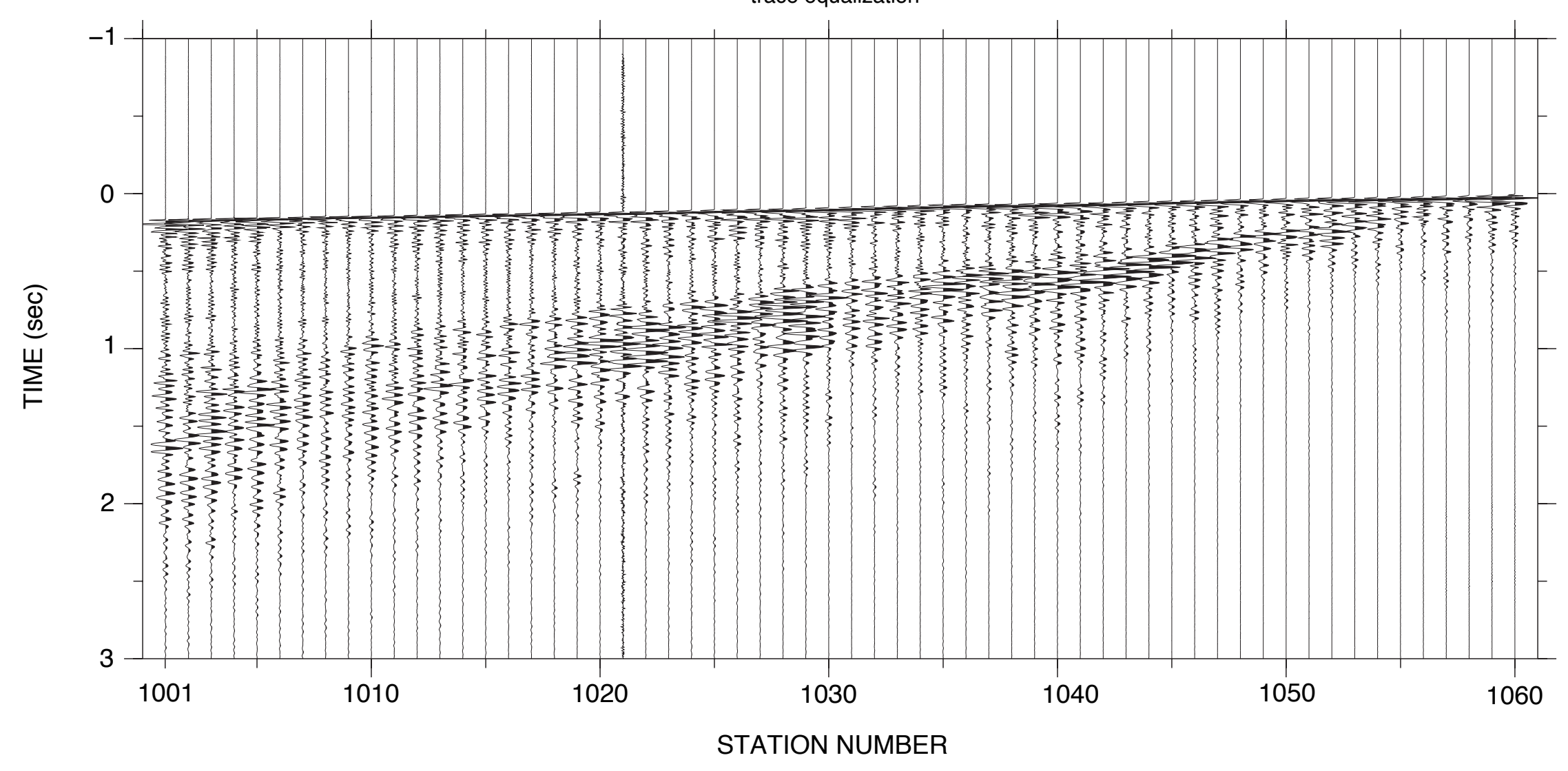


Appendix 5. Velocity Plots for N-S Linear Profile

[Near-field to far-field transition. Zero time is the moment of detonation of the shot.] 


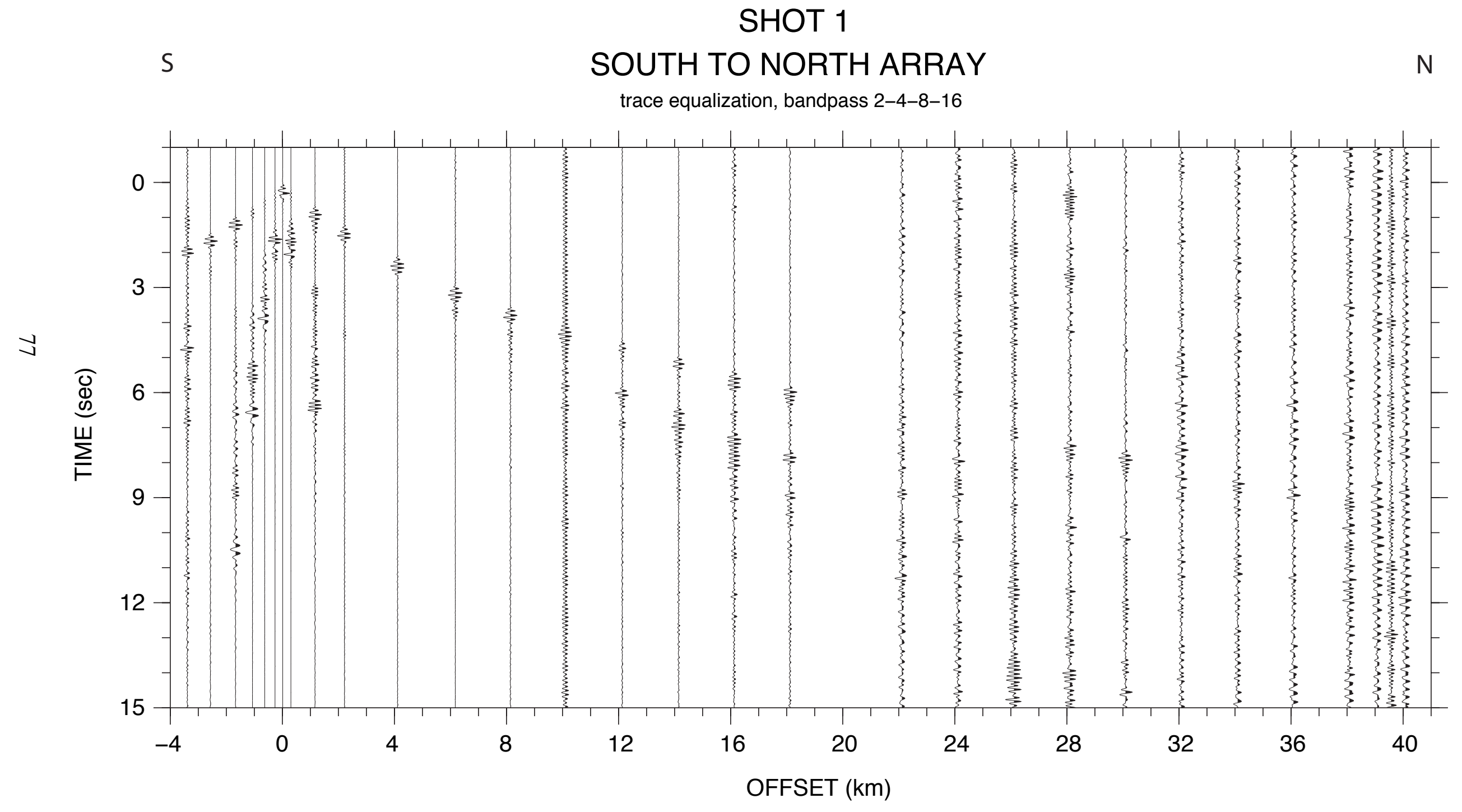


SHOT 2

SOUTH TO NORTH ARRAY

trace equalization, bandpass 2-4-8-16

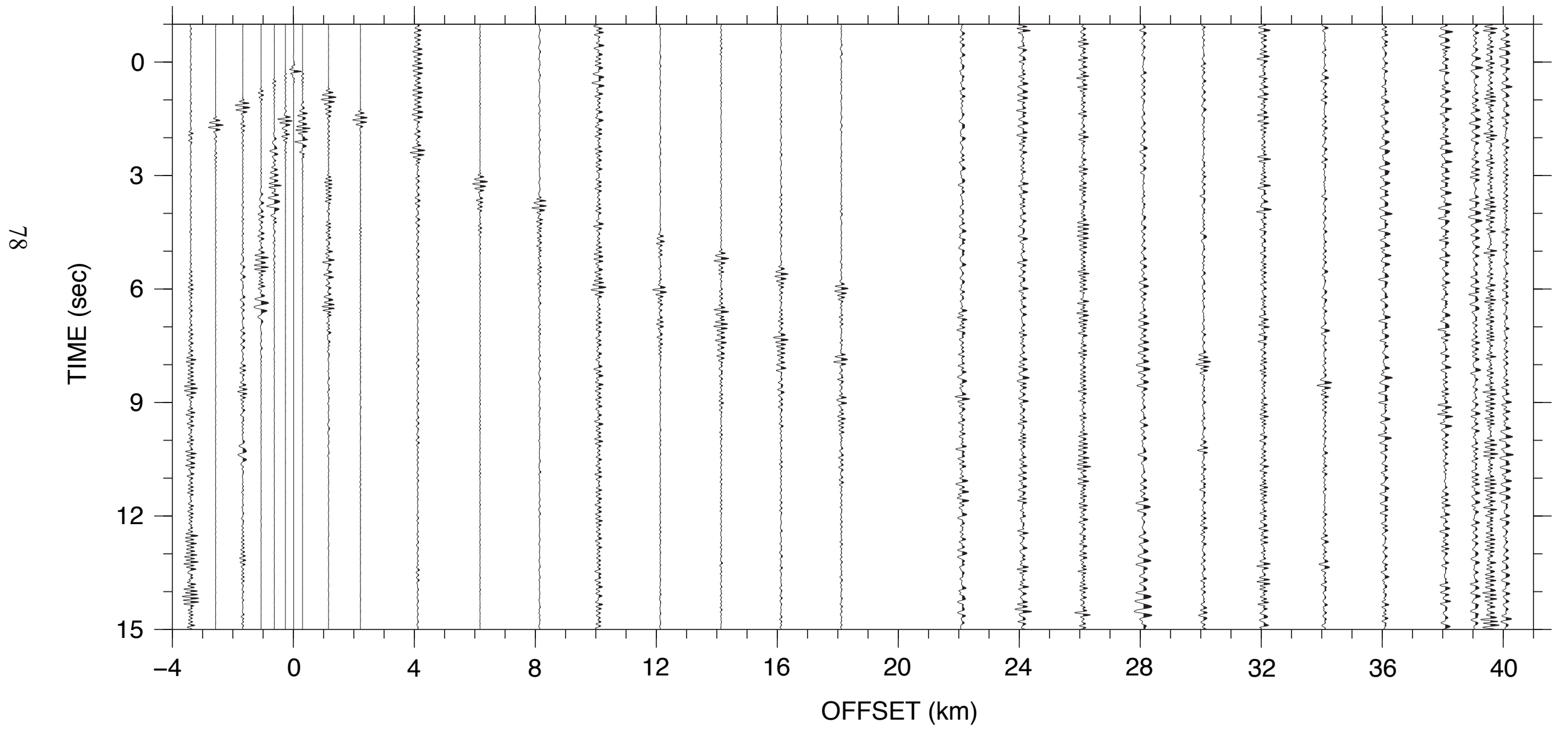




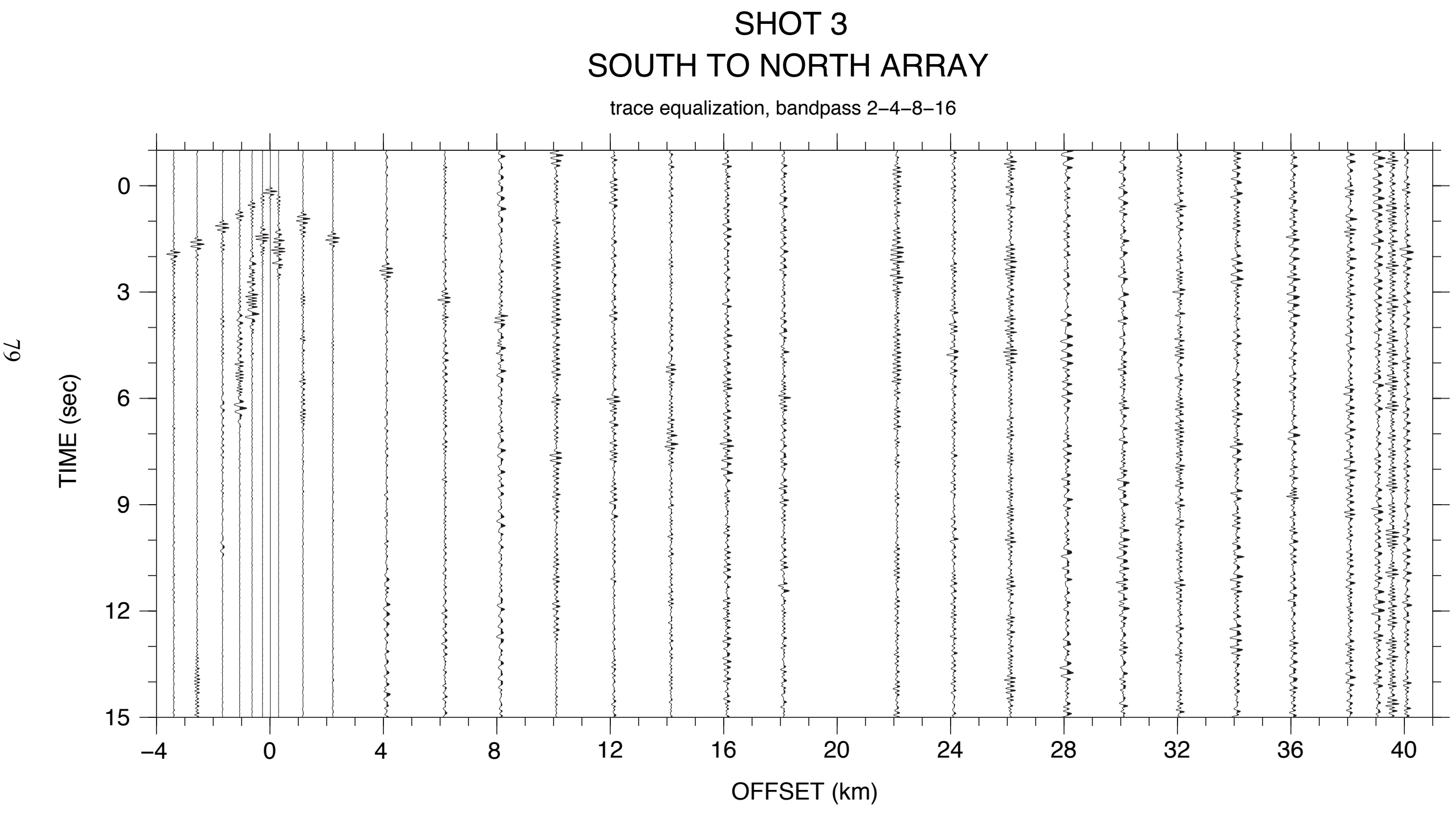

